In cooperation with the Utah Department of Natural Resources, Division of Water Rights

\title{
Hydrology and Numerical Simulation of Groundwater Flow and Streamflow Depletion by Well Withdrawals in the Malad-Lower Bear River Area, Box Elder County, Utah
}

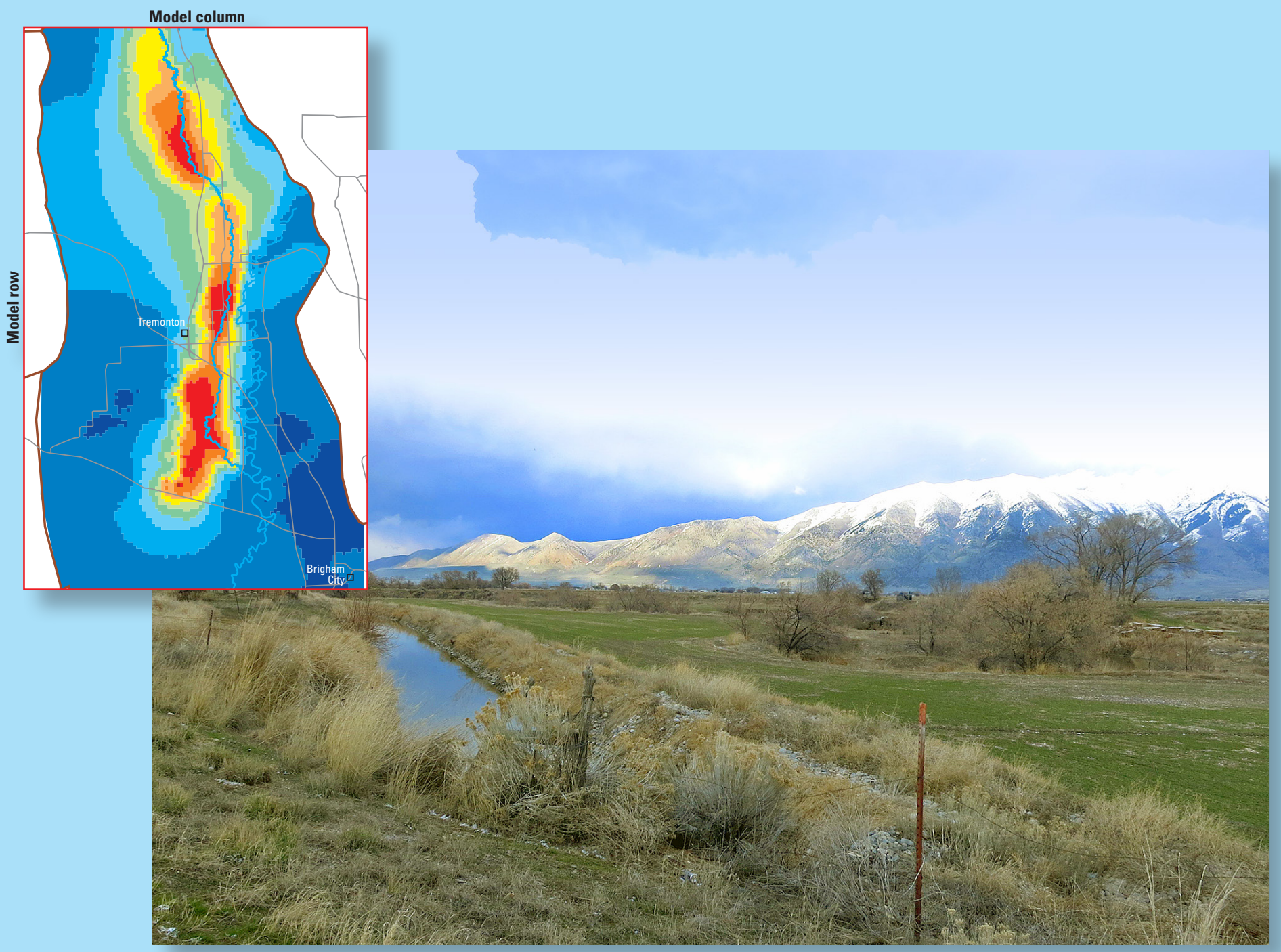

Scientific Investigations Report 2017-5011 
Cover photograph: Looking northeast along the Bear River Duck Club Canal toward the Wellsville Mountains, Bernard Stolp, U.S. Geological Survey, April 2013. 


\section{Hydrology and Numerical Simulation of Groundwater Flow and Streamflow Depletion by Well Withdrawals in the Malad-Lower Bear River Area, Box Elder County, Utah}

By Bernard J. Stolp, Lynette E. Brooks, and John E. Solder

In cooperation with the Utah Department of Natural Resources, Division of Water Rights

Scientific Investigations Report 2017-5011 


\title{
U.S. Department of the Interior \\ RYAN K. ZINKE, Secretary
}

\section{U.S. Geological Survey William H. Werkheiser, Acting Director}

\author{
U.S. Geological Survey, Reston, Virginia: 2017
}

For more information on the USGS - the Federal source for science about the Earth, its natural and living resources, natural hazards, and the environment—visit http://www.usgs.gov or call 1-888-ASK-USGS.

For an overview of USGS information products, including maps, imagery, and publications, visit http://store.usgs.gov/.

Any use of trade, firm, or product names is for descriptive purposes only and does not imply endorsement by the U.S. Government.

Although this information product, for the most part, is in the public domain, it also may contain copyrighted materials as noted in the text. Permission to reproduce copyrighted items must be secured from the copyright owner.

Suggested citation:

Stolp, B.J., Brooks, L.E., and Solder, J.E., 2017, Hydrology and numerical simulation of groundwater flow and streamflow depletion by well withdrawals in the Malad-Lower Bear River Area, Box Elder County, Utah: U.S. Geological Survey Scientific Investigations Report 2017-5011, 113 p., 6 appendixes, https://doi.org/10.3133/sir20175011.

ISSN 2328-0328 (online) 


\section{Contents}

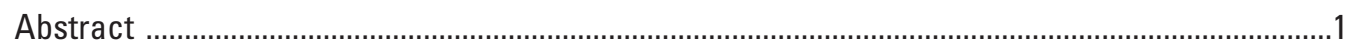

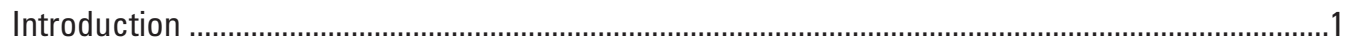

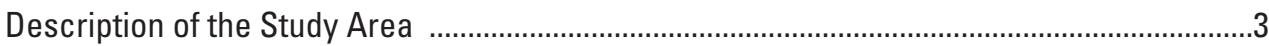

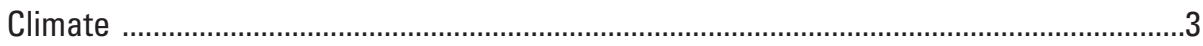

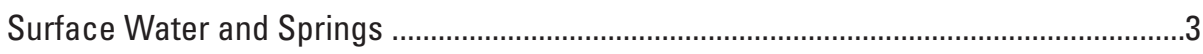

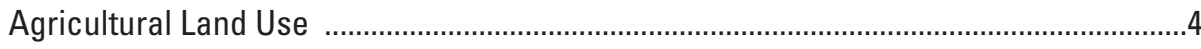

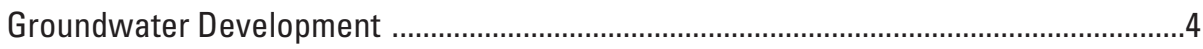

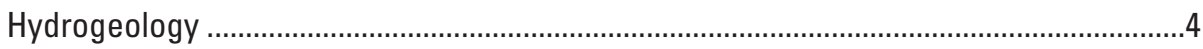

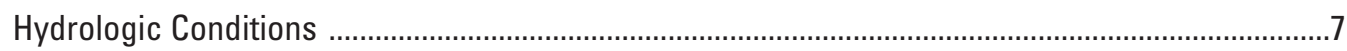

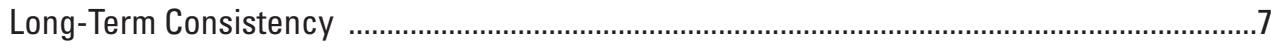

Short-Term Fluctuations .................................................................................................

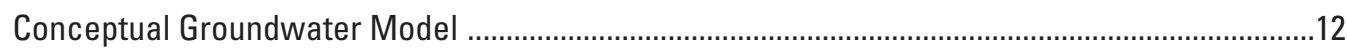

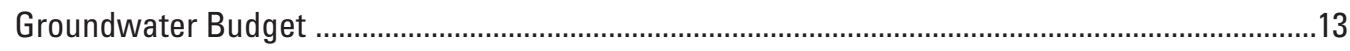

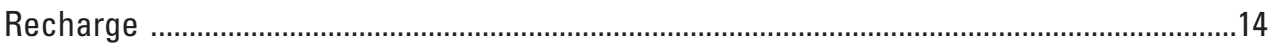

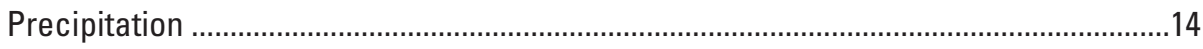

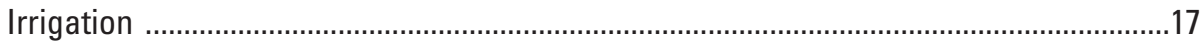

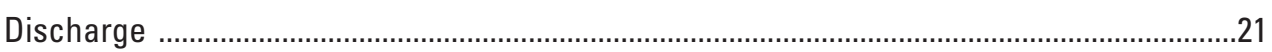

Malad and Bear Rivers .............................................................................................21

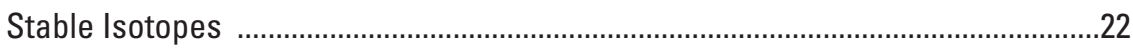

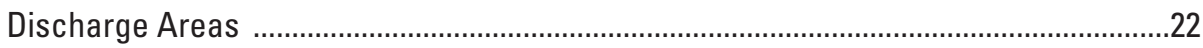

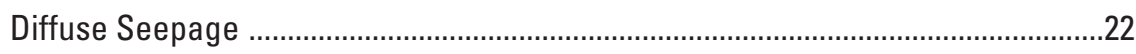

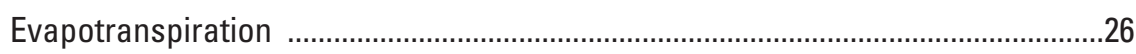

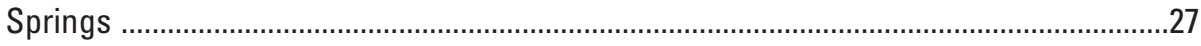

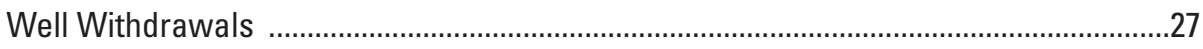

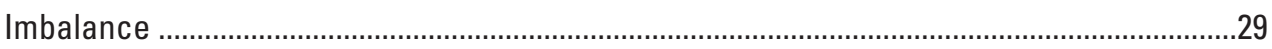

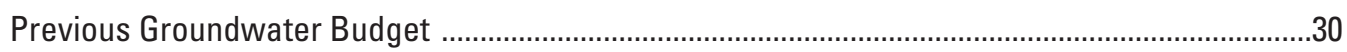

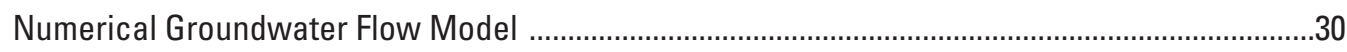

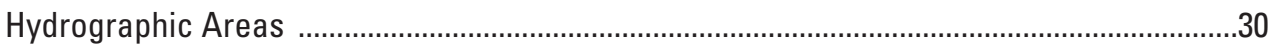

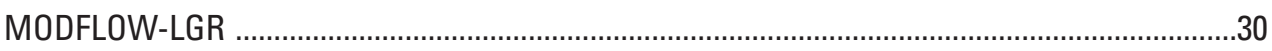

Existing Great Basin Carbonate and Alluvial Aquifer System Model .....................................33

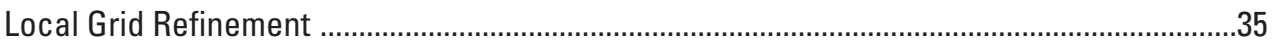

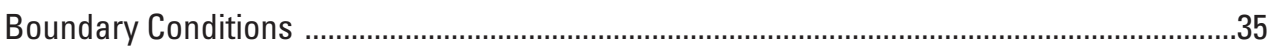

Specified-Flow Boundaries ..........................................................................................35

Recharge from Precipitation, Ephemeral Streams, and Irrigation ..........................35

Wells ......................................................................................................

Head-Dependent Boundaries .....................................................................................

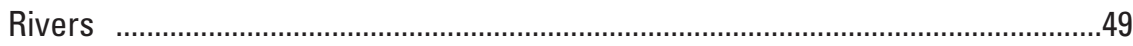

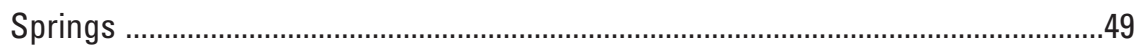

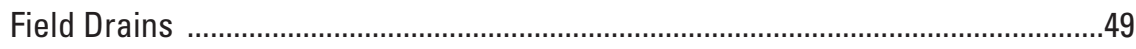

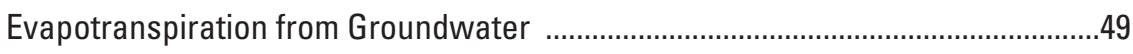

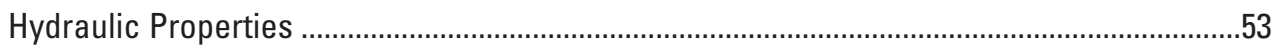

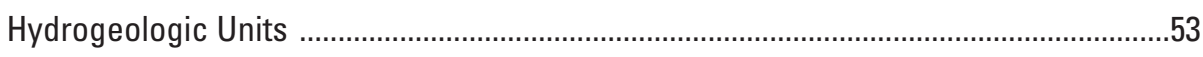

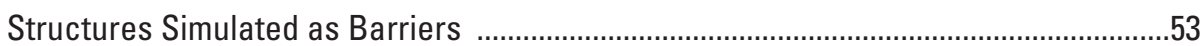


Observations Used in Model Calibration ............................................................................53

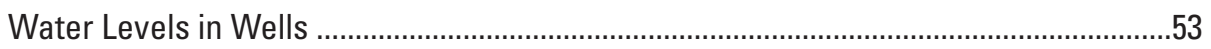

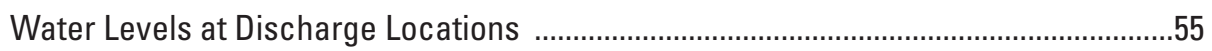

Groundwater Discharge and Uncertainty .....................................................................

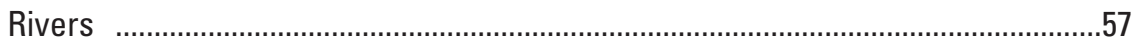

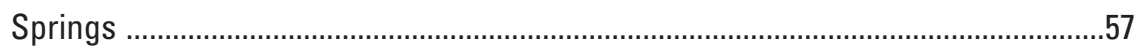

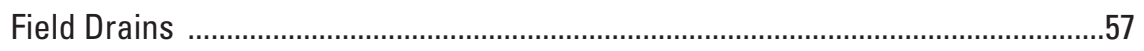

Evapotranspiration from Groundwater ..............................................................

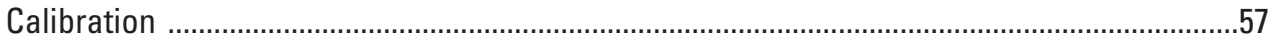

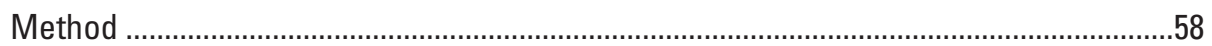

Parameter Values in Calibrated Model ...................................................................59

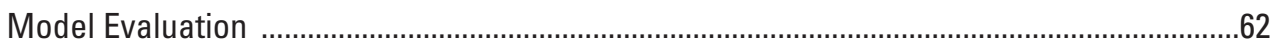

Model Fit to Observations ......................................................................................

Water-Level Observations ........................................................................................62

Discharge Observations ........................................................................................... 64

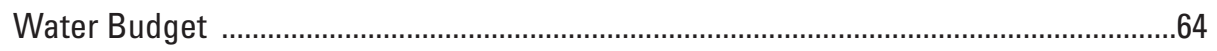

Simulated Streamflow Capture ..........................................................................................

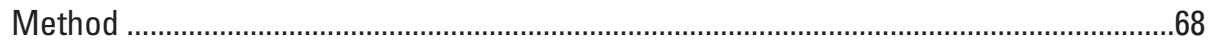

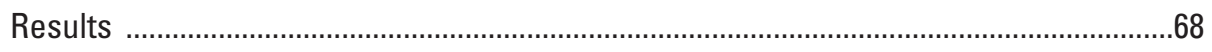

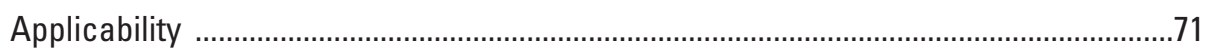

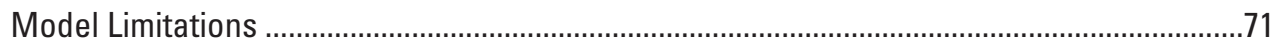

Appropriate Uses of the Model ...........................................................................................

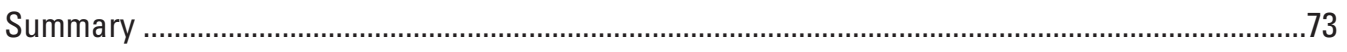

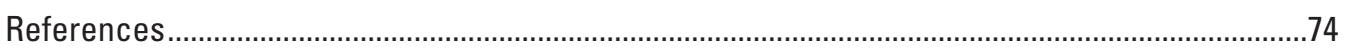

Appendix 1. Miscellaneous Tables ........................................................................................

Appendix 2. Seepage Assessments ...................................................................................

Appendix 3. Observations and Error Analysis Used in the Numerical Groundwater

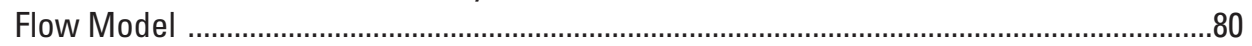

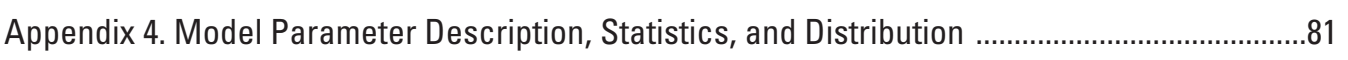

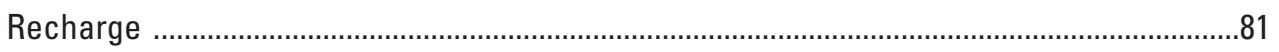

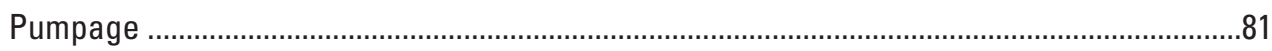

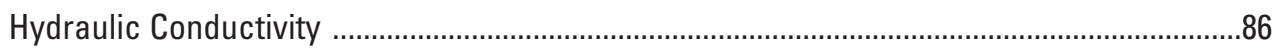

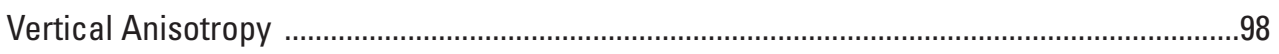

Drain and River Conductance .....................................................................................98

Horizontal-Flow Barriers ..............................................................................................98

Appendix 5. Changes to the Numerical Groundwater Flow Model Outside of the

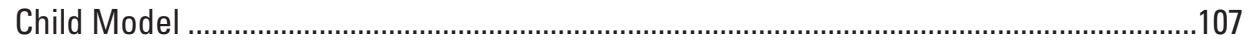

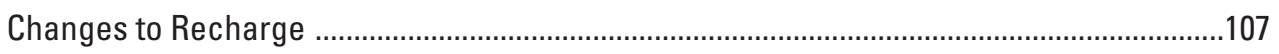

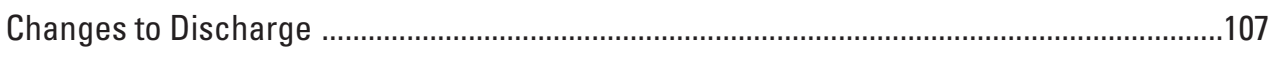

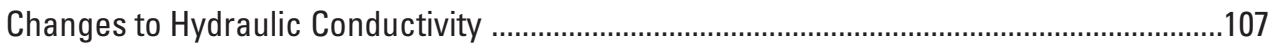

Appendix 6. Model Results .....................................................................................................108 


\section{Figures}

1. Map showing location of Malad-Lower Bear River study area and U.S. Geological Survey streamflow gaging stations

2. Graph showing average annual precipitation measured at Brigham City, Corinne, Cutler Dam, Garland, Plymouth, Thiokol, and Tremonton, for the period 1949-2011, MaladLower Bear River study area

3. Map showing distribution of agricultural lands, Malad-Lower Bear River study area .5

4. Map showing location of known field drains, Malad-Lower Bear River study area .......................6

5. Map showing location of wells and changes in measured water levels from 1971 to 2013, Malad-Lower Bear River study area

6. Boxplot showing water levels measured in selected wells in March 1971 and March 2013, Malad-Lower Bear River study area

7. Graph showing annual water-level fluctuations in selected wells from 1971 to 2013, MaladLower Bear River study area

8. Graph showing cumulative difference in flow between the Bear River at Collinston and Corinne, and cumulative precipitation, Malad-Lower Bear River study area

9. Schematic diagram showing the conceptual groundwater system, Malad-Lower Bear River study area

10. Map showing distribution of average annual 1940-2006 recharge and runoff from the Basin Characterization Model, Malad-Lower Bear River study area

11. Map showing Basin Characterization Model multiplier areas, Malad-Lower Bear River study area ...18

12. Map showing irrigation areas, Malad-Lower Bear River study area . .19

13. Map showing locations and plot of $\delta^{18} 0$ versus $\delta^{2} \mathrm{H}$ for samples collected from the West Canal, Malad River, and surrounding areas, Malad-Lower Bear River study area

14. Map showing groundwater discharge areas, Malad-Lower Bear River study area

15. Map showing measurement locations used to estimate 1972-1986 average annual volume of surface-water flow at State Highway 83, Malad-Lower Bear River study area ....................26

16. Map showing location of selected springs, Malad-Lower Bear River study area $\ldots 28$

17. Graph showing annual municipal and irrigation well withdrawals, 1976-2013, MaladLower Bear River study area

18. Map showing hydrographic areas near the Malad-Lower Bear River study area, Utah and Idaho

19. Map showing location of the Great Basin carbonate and alluvial aquifer system groundwater model and area of local grid refinement, Malad-Lower Bear River study area ...............32

20. Map showing simulated groundwater regions in the GBCAAS v. 1.0 groundwater model, Great Basin carbonate and alluvial aquifer system study area

21. Map showing model grid refinement for the HA273UTchild model, Malad-Lower Bear River study area

22. Map showing thickness of layer 1 in the HA273UTchild model and location of cross sections, Malad-Lower Bear River study area

23. Cross sections showing model layer and hydrogeologic thicknesses in the HA273UTchild model, Malad-Lower Bear River study area

24. Map showing rates of conceptual recharge and runoff from various sources, MaladLower Bear study area and surrounding areas, Utah and Idaho

25. Map showing location of simulated groundwater withdrawals by wells in the HA273UTchild model, Malad-Lower Bear River study area 
26. Map showing conceptual discharge to springs and rivers simulated in the HA273UTchild model, Malad-Lower Bear River study area

27. Map showing conceptual discharge to area springs, field drains, and evapotranspiration in the HA273UTchild model, Malad-Lower Bear River study area

28. Diagram showing calculation of drain conductance used to simulate evapotranspiration of groundwater in the HA273UTchild model, Malad-Lower Bear River study area .52

29. Map showing horizontal-flow barriers representing selected faults in the HA273UTchild model, Malad-Lower Bear River study area

30. Map showing model-layer distribution of water-level observations at wells used in the HA273UTchild model, Malad-Lower Bear River study area

31. Bar chart showing composite scaled sensitivities for final parameters used in the HA273UTchild model, Malad-Lower Bear River study area

32. Graph showing values and linear confidence intervals of final parameters used in the HA273UTchild model, Malad-Lower Bear River study area 61

33. Graphs showing weighted residuals in the HA273UTchild model, Malad-Lower Bear River study area

34. Map showing distribution of residuals of water levels in wells in the HA273UTchild model, Malad-Lower Bear River study area

35. Map showing simulated discharge, as percent of observed discharge in the HA273UTchild model, Malad-Lower Bear River study area

36. Map showing selected simulated groundwater divide in the GBCAAS v. 2.0 groundwater model, Malad-Lower Bear River study area and surrounding areas, Utah and Idaho

37. Maps showing simulated reduction in flow in the Malad River, Sulphur Creek, the Bear River, and springs as a fraction of pumping rate that would result from long-term pumping from layer 2 at a pumping rate of 43,200 cubic feet per day, Malad-Lower Bear River study area

38. Maps showing simulated reduction in flow in the Malad River as a fraction of pumping rate that would result from long-term pumping from layer 2 and layer 3 at a pumping rate of 43,200 cubic feet per day, and the difference in capture percent between layers 2 and 3, Malad-Lower Bear River study area

A2-1. Map showing location of seepage assessment measurements on the Bear and Malad Rivers, Malad-Lower Bear River study area

A4-1. Map showing model parameter distribution for recharge in the GBCAAS v. 2.0 groundwater model, Malad-Lower Bear River study area and surrounding areas, Utah and Idaho

A4-2. Map showing distribution of simulated recharge in the GBCAAS v. 2.0 groundwater model, Malad-Lower Bear River study area and surrounding areas, Utah and Idaho

A4-3. Map showing distribution of hydraulic conductivity of the non-carbonate confining unit in the GBCAAS v. 2.0 groundwater model, Malad-Lower Bear River study area and surrounding areas, Utah and Idaho

A4-4. Map showing distribution of model parameters defining hydraulic conductivity of the noncarbonate confining unit in the GBCAAS v. 2.0 groundwater model, Malad-Lower Bear River study area and surrounding areas, Utah and Idaho

A4-5. Map showing distribution of hydraulic conductivity of the lower carbonate aquifer unit in the GBCAAS v. 2.0 groundwater model, Malad-Lower Bear River study area and surrounding areas, Utah and Idaho

A4-6. Map showing distribution of model parameters defining hydraulic conductivity of the lower carbonate aquifer unit in the GBCAAS v. 2.0 groundwater model, Malad-Lower Bear River study area and surrounding areas, Utah and Idaho

A4-7. Map showing distribution of hydraulic conductivity of the upper siliciclastic confining unit in the GBCAAS v. 2.0 groundwater model, Malad-Lower Bear River study area and surrounding areas, Utah and Idaho 
A4-8. Map showing distribution of hydraulic conductivity of the upper basin-fill aquifer unit in the GBCAAS v. 2.0 groundwater model, Malad-Lower Bear River study area and surrounding areas, Utah and Idaho

A4-9. Map showing distribution of model parameters defining hydraulic conductivity of the upper basin-fill aquifer unit in the GBCAAS v. 2.0 groundwater model, Malad-Lower Bear River study area and surrounding areas, Utah and Idaho

A4-10. Map showing distribution of vertical anisotropy of the upper basin-fill aquifer unit in the GBCAAS v. 2.0 groundwater model, Malad-Lower Bear River study area and surrounding areas, Utah and Idaho

A4-11. Map showing distribution of parameter values for evapotranspiration of groundwater in the GBCAAS v. 2.0 groundwater model, Malad-Lower Bear River study area and surrounding areas, Utah and Idaho....

A4-12. Map showing distribution of simulated evapotranspiration in the GBCAAS v. 2.0 groundwater model, Malad-Lower Bear River study area and surrounding areas, Utah and Idaho

A6-1. Map showing change in simulated water levels in layer 1 from the GBCAAS v. 1.0 to the GBCAAS v. 2.0 groundwater models, Malad-Lower Bear River study area and surrounding areas, Utah and Idaho

A6-2. Map showing location and model fit of observations used for calibration in the GBCAAS v. 2.0 groundwater model, Malad-Lower Bear River study area and surrounding areas, Utah and Idaho

A6-3. Map showing direction of simulated subsurface flow between hydrographic areas in the GBCAAS v. 2.0 groundwater model, Great Basin carbonate and alluvial aquifer system study area

\section{Tables}

1. Average annual groundwater budget, Malad-Lower Bear River study area ...............................13

2. Groundwater recharge from precipitation, Malad-Lower Bear River study area ..........................17

3. Groundwater recharge from irrigation, Malad-Lower Bear River study area...............................20

4. Average annual diversion from major canals to irrigation areas, Malad-Lower Bear River study area

5. Groundwater discharge to the Bear and Malad Rivers, Malad-Lower Bear River study area ....21

6. Groundwater discharge as diffuse seepage, Malad-Lower Bear River study area ....................25

7. Average annual surface-water flow at State Highway 83, Malad-Lower Bear River study area

8. Groundwater discharge as evapotranspiration, Malad-Lower Bear River study area ................27

9. Spring discharge for generalized areas, Malad-Lower Bear River study area ............................29

10. Summary statistics of observations in the GBCAAS v. 2.0 groundwater model, Great Basin carbonate and alluvial aquifer system study area

11. Horizontal hydraulic-conductivity estimates of hydrogeologic units in the Death Valley regional groundwater flow system and the Great Basin carbonate and alluvial aquifer system study area

12. Estimates of properties describing parameter values for recharge, drains, rivers, horizontalflow barriers, vertical anisotropy, and wells in the GBCAAS v. 2.0 groundwater model, Great Basin carbonate and alluvial aquifer system study area

13. Prior-information statistics for selected parameters in the GBCAAS v. 2.0 groundwater model, Great Basin carbonate and alluvial aquifer system study area 
14. Summary statistics for measures of model fit, HA273UTchild model, Malad-Lower Bear River study area

15. Simulated and conceptual groundwater budget, Malad-Lower Bear River study area .68

A1-1. Water levels in selected wells, March 1971 and March 2013, Malad-Lower Bear River study area

A1-2. Mean crop acreage within individual irrigation areas, Malad-Lower Bear River study area .....77

A1-3. Average irrigated acreage, effective precipitation, and representative crop consumptive use for irrigation areas, Malad-Lower Bear River study area

A1-4. Discharge measurements of irrigation canals across State Highway 83, Malad-Lower Bear River study area

A1-5. Tailwater from irrigation areas, Malad-Lower Bear River study area 77

A1-6. Surface-water inflow, spring discharge, and surface-water outflow used to estimate groundwater discharge as diffuse seepage, Malad-Lower Bear River study area

A1-7. Miscellaneous discharge measurements of culverts and bridges across State Highway 83, Malad-Lower Bear River study area

A1-8. Detailed description of groundwater discharge as evapotranspiration from groundwater discharge areas, Malad-Lower Bear River study area

A1-9. Discharge from selected springs, ditches, and drains, Malad-Lower Bear River study area .....77

A1-10. Results of stable isotope analysis of water from selected springs, streams, and wells, Malad-Lower Bear River study area

A1-11. Annual diversions to West Canal and East Hammond Canal, Malad-Lower Bear River study area

A2-1. Discharge measurements of selected rivers, creeks, and canals, Malad-Lower Bear River study area

A2-2. Calculations of groundwater discharge to selected rivers and creeks, Malad-Lower Bear River study area

A3-1. Well data, water-level observation, observation variance, simulated values, and simulated residuals for observations of water levels in wells in selected areas of the GBCAAS v. 2.0 groundwater model, Malad-Lower Bear River study area and surrounding areas, Utah and Idaho

A3-2. Model observations for discharge to Bear River, Malad River, and Sulphur Creek area in the HA273UTchild model, Malad-Lower Bear River study area

A3-3. Model observations for discharge to selected springs, field drains, and evapotranspiration in the GBCAAS v. 2.0 groundwater model, Malad-Lower Bear River study area .........80

A3-4. Discharge of municipal springs and model observations in the GBCAAS v. 2.0 groundwater model, Malad-Lower Bear River study area

A3-5. Selected springs not simulated explicitly in the GBCAAS v. 2.0 groundwater model, Malad-Lower Bear River study area

A3-6. Simulated discharge at each discharge observation in the Great Salt Lake model region of the GBCAAS v. 2.0 groundwater model, Great Basin carbonate and alluvial aquifer system study area

A4-1. Model zones, multiplier arrays, and parameter values and statistics for recharge, pumpage, and lateral flow boundaries in the GBCAAS v. 2.0 groundwater model, Great Basin carbonate and alluvial aquifer system study area

A4-2. Hydrogeologic zones, model zones, and parameter values and statistics for horizontal hydraulic conductivity of the confining units in the GBCAAS v. 2.0 groundwater model, Great Basin carbonate and alluvial aquifer system study area

A4-3. Hydrogeologic zones, model zones, and parameter values and statistics for horizontal hydraulic conductivity of the carbonate aquifer units in the GBCAAS v. 2.0 groundwater model, Great Basin carbonate and alluvial aquifer system study area 
A4-4. Hydrogeologic zones, model zones, and parameter values and statistics for horizontal hydraulic conductivity of the volcanic and basin-fill units in the GBCAAS v. 2.0 groundwater model, Great Basin carbonate and alluvial aquifer system study area

A4-5. Parameter values and statistics for horizontal-to-vertical anisotropy of all hydrogeologic units in the GBCAAS v. 2.0 groundwater model, Great Basin carbonate and alluvial aquifer system study area

A4-6. Simulated values at discharge observations for different values of vertical anisotropy of the upper basin-fill aquifer unit in the HA273UTchild model, Malad-Lower Bear River study area

A4-7. Parameter values and statistics for evapotranspiration conductance multiplier, drain leakance, river conductivity, and river leakance in the GBCAAS v. 2.0 groundwater model, Great Basin carbonate and alluvial aquifer system study area

A4-8. Parameter values and statistics for the hydraulic characteristic of horizontal-flow barriers in the GBCAAS v. 2.0 groundwater model, Great Basin carbonate and alluvial aquifer system study area

A6-1. Groundwater budgets for the simulated groundwater regions and subregions in the GBCAAS v. 2.0 groundwater model, Great Basin carbonate and alluvial aquifer system study area

A6-2. Comparison of conceptual and simulated recharge and discharge for each hydrographic area in the GBCAAS v. 2.0 groundwater model, Great Basin carbonate and alluvial aquifer system study area

A6-3. Model-predicted flow between hydrographic areas in the GBCAAS v. 2.0 groundwater model, Great Basin carbonate and alluvial aquifer system study area 


\section{Conversion Factors, Datums, and Water-Quality Units}

Inch/Pound to International System of Units

\begin{tabular}{|c|c|c|}
\hline Multiply & By & To obtain \\
\hline \multicolumn{3}{|c|}{ Length } \\
\hline foot $(\mathrm{ft})$ & 0.3048 & meter $(\mathrm{m})$ \\
\hline mile (mi) & 1.609 & kilometer (km) \\
\hline \multicolumn{3}{|c|}{ Area } \\
\hline square foot $\left(\mathrm{ft}^{2}\right)$ & 0.09290 & square meter $\left(\mathrm{m}^{2}\right)$ \\
\hline square mile $\left(\mathrm{mi}^{2}\right)$ & 2.590 & square kilometer $\left(\mathrm{km}^{2}\right)$ \\
\hline \multicolumn{3}{|c|}{ Volume } \\
\hline acre-foot (acre-ft) & 1,233 & cubic meter (m3) \\
\hline \multicolumn{3}{|c|}{ Flow rate } \\
\hline acre-foot per year (acre-ft/yr) & 1,233 & cubic meter per year $\left(\mathrm{m}^{3} / \mathrm{yr}\right)$ \\
\hline foot per day (ft/d) & 0.3048 & meter per day (m/d) \\
\hline foot per year (ft/yr) & 0.3048 & meter per year (m/yr) \\
\hline cubic foot per second $\left(\mathrm{ft}^{3} / \mathrm{s}\right)$ & 0.02832 & cubic meter per second $\left(\mathrm{m}^{3} / \mathrm{s}\right)$ \\
\hline cubic foot per day $\left(\mathrm{ft}^{\mathrm{t}} / \mathrm{d}\right)$ & 0.02832 & cubic meter per day $\left(\mathrm{m}^{3} / \mathrm{d}\right)$ \\
\hline inch per year (in/yr) & 25.4 & millimeter per year (mm/yr) \\
\hline gallon per minute (gal/min) & 0.06309 & liter per second $(\mathrm{L} / \mathrm{s})$ \\
\hline \multicolumn{3}{|c|}{ Hydraulic conductivity } \\
\hline foot per day (ft/d) & 0.3048 & meter per day $(\mathrm{m} / \mathrm{d})$ \\
\hline \multicolumn{3}{|c|}{ Transmissivity* } \\
\hline foot squared per day $\left(\mathrm{ft}^{2} / \mathrm{d}\right)$ & 0.09290 & meter squared per day $\left(\mathrm{m}^{2} / \mathrm{d}\right)$ \\
\hline \multicolumn{3}{|c|}{ Leakance $^{* *}$} \\
\hline per day $(/ d)$ & 1 & per day $(/ d)$ \\
\hline
\end{tabular}

Temperature in degrees Celsius $\left({ }^{\circ} \mathrm{C}\right)$ can be converted to degrees Fahrenheit $\left({ }^{\circ} \mathrm{F}\right)$ as follows:

$$
{ }^{\circ} \mathrm{F}=\left(1.8 \times{ }^{\circ} \mathrm{C}\right)+32 .
$$

Temperature in degrees Fahrenheit $\left({ }^{\circ} \mathrm{F}\right)$ can be converted to degrees Celsius $\left({ }^{\circ} \mathrm{C}\right)$ as follows:

${ }^{\circ} \mathrm{C}=\left({ }^{\circ} \mathrm{F}-32\right) / 1.8$.

Vertical coordinate information is referenced to the North American Vertical Datum of 1988 (NAVD 88).

Horizontal coordinate information is referenced to the North American Datum of 1983 (NAD 83).

Altitude, as used in this report, refers to distance above the vertical datum.

*Transmissivity: The standard unit for transmissivity is cubic foot per day per square foot times foot of aquifer thickness [( $\left.\left.\mathrm{ft}^{3} / \mathrm{d}\right) / \mathrm{ft}^{2}\right] \mathrm{ft}$. In this report, the mathematically reduced form, foot squared per day $\left(\mathrm{ft}^{2} / \mathrm{d}\right)$, is used for convenience.

**Leakance: The standard unit for leakance is feet per day per foot [(ft/d)/ft]. In this report, the mathematically reduced form, per day $(/ d)$, is used for convenience. 


\section{Wells by the Cadastral System of Land Subdivision}

The well-numbering system used in Utah is based on the Cadastral system of land subdivision. The well-numbering system is familiar to most water users in Utah, and the well number shows the location of the well by quadrant, township, range, section, and position within the section. Well numbers for most of the State are referenced to the Salt Lake Base Line and Meridian. This system is also used for spring numbers.

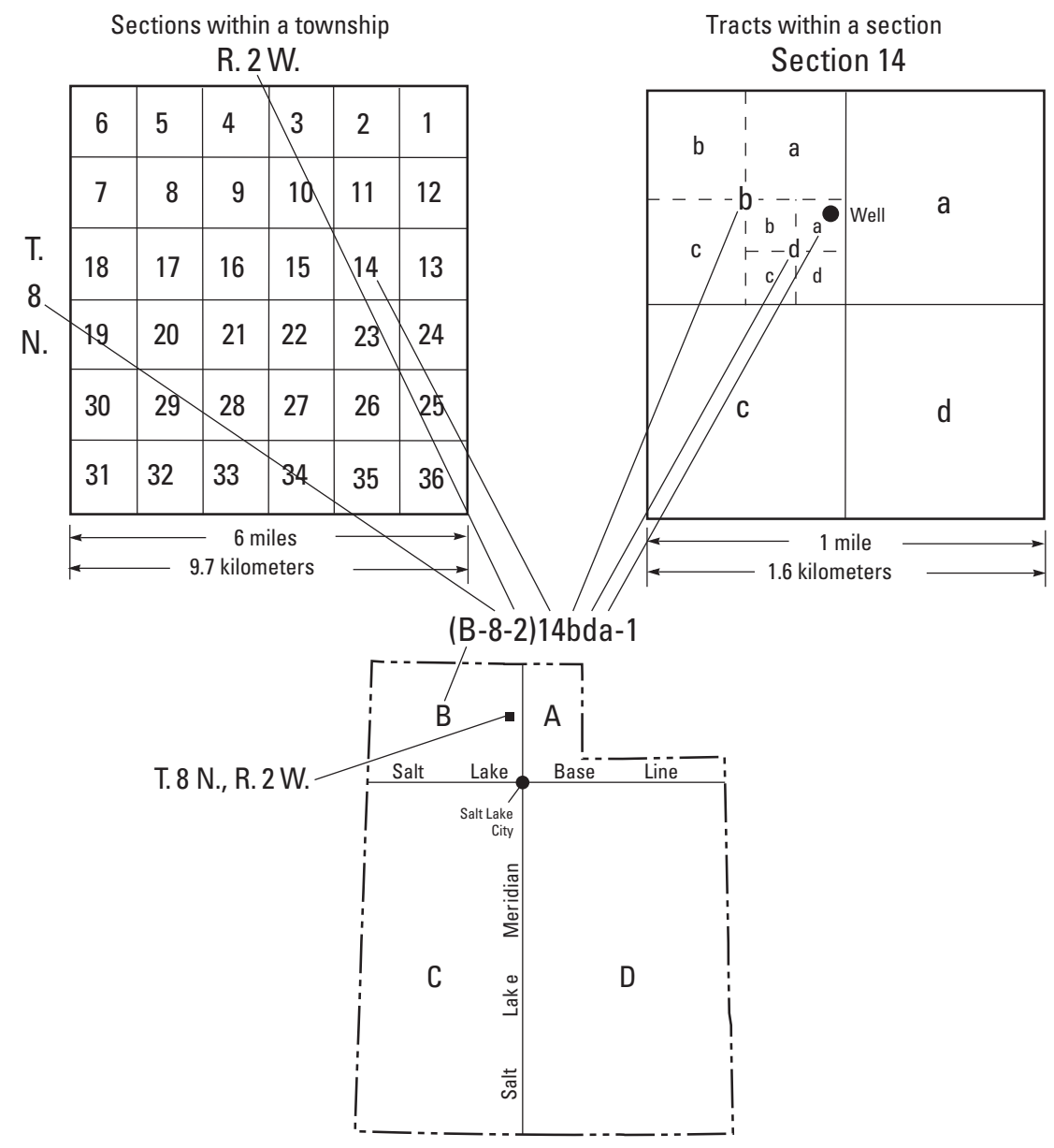

\section{Surface-Water Sites-Downstream Order and Station Number}

Since October 1, 1950, hydrologic-station records in U.S. Geological Survey reports have been listed in order of downstream direction along the mainstem. All stations on a tributary entering upstream from a mainstem station are listed before that station. A station on a tributary entering between two mainstem stations is listed between those stations.

As an added means of identification, each hydrologic station and partial-record station has been assigned a station number. These station numbers are in the same downstream order used in this report. In assigning a station number, no distinction is made between partial-record stations and other stations; therefore, the station number for a partial-record station indicates downstream order position in a list comprising both types of stations. Gaps are consecutive. The complete 8-digit (or 10-digit) number for each station such as 10125600 , which appears just to the left of the station name, includes a 2-digit part number "10" plus the 6-digit (or 8-digit) downstream order number "125600." In areas of high station density, an additional two digits may be added to the station identification number to yield a 10-digit number. The stations are numbered in downstream order as described above between stations of consecutive 8-digit numbers. 


\title{
Hydrology and Numerical Simulation of Groundwater Flow and Streamflow Depletion by Well Withdrawals in the Malad-Lower Bear River Area, Box Elder County, Utah
}

\author{
By Bernard J. Stolp, Lynette E. Brooks, and John E. Solder
}

\section{Abstract}

The Malad-Lower Bear River study area in Box Elder County, Utah, consists of a valley bounded by mountain ranges and is mostly agricultural or undeveloped. The Bear and Malad Rivers enter the study area with a combined average flow of about 1,100,000 acre-feet per year (acre-ft/yr), and this surface water dominates the hydrology. Groundwater occurs in consolidated rock and basin fill. Groundwater recharge occurs from precipitation in the mountains and moves through consolidated rock to the basin fill. Recharge occurs in the valley from irrigation. Groundwater discharge occurs to rivers, springs and diffuse seepage areas, evapotranspiration, field drains, and wells. Groundwater, including springs, is a source for municipal and domestic water supply. Although withdrawal from wells is a small component of the groundwater budget, there is concern that additional groundwater development will reduce the amount of flow in the Malad River. Historical records of surface-water diversions, land use, and groundwater levels indicate relatively stable hydrologic conditions from the 1960s to the 2010s, and that current groundwater development has had little effect on the groundwater system. Average annual recharge to and discharge from the groundwater flow system are estimated to be 164,000 and 228,000 acre-ft/yr, respectively. The imbalance between recharge and discharge represents uncertainties resulting from system complexities, and the possibility of groundwater inflow from surrounding basins.

This study reassesses the hydrologic system, refines the groundwater budget, and creates a numerical groundwater flow model that is used to analyze the effects of groundwater withdrawals on surface water. The model uses the detailed catalog of locations and amounts of groundwater recharge and discharge defined during this study. Calibrating the model to adequately simulate recharge, discharge, and groundwater levels results in simulated aquifer properties that can be used to understand the relation between pumping and the reduction in discharge to rivers, springs, natural vegetation, and field drains. Simulations run by the calibrated model were used to calculate the reduction of groundwater discharge to the Malad River (stream depletion) in response to a well withdrawal of 360 acre-ft/yr at any location within the study area. Modeling results show that streamflow depletion in the Malad River depends on both depth and location of groundwater withdrawal, and varies from less than 1 percent to 96 percent of the well withdrawal. The relation between simulated withdrawal and reductions in Malad River streamflow, Bear River streamflow, and spring discharge are shown on capture maps.

\section{Introduction}

The Malad-Lower Bear River study area in Box Elder County, Utah, is about 70 miles (mi) north of Salt Lake City, and consists of a valley bounded by mountain ranges (fig. 1). The area is mostly agricultural or undeveloped. The largest population centers are Brigham City and Tremonton. Surface water dominates the hydrology; surface water entering the study area is about five times more than estimated groundwater flow within the area. The Bear River enters the area with an average flow of 1,060,000 acre-feet per year (acre-ft/yr), supplies 240,000 acre-ft/yr of irrigation water, and provides water to the wetlands and migratory bird refuge north of Great Salt Lake. The Malad River enters the area with an average flow of $51,000 \mathrm{acre}-\mathrm{ft} / \mathrm{yr}$, has minor irrigation use, and is used to support wetlands and wildlife habitat in the southern part of the study area. The study area contains many large springs, some of which are used for municipal water use, and some of which provide additional water to the rivers and wetlands.

Groundwater supplies all non-irrigation municipal and domestic water, mostly from springs in or near the eastern mountains. Withdrawals from wells for municipal, domestic, and irrigation use are a small component of the groundwater budget, and groundwater development has had little effect on the groundwater system. Increases in groundwater appropriation, however, are being requested to expand irrigated cropland and supplement municipal, domestic, and industrial water supplies. There is concern that additional groundwater development will impact surface water and associated water rights. A specific concern is that additional groundwater development will reduce the amount of flow in the Malad River. To better understand the reduction of groundwater flow to the Malad River (streamflow depletion) in response to groundwater withdrawals from wells, the U.S. Geological Survey (USGS), in cooperation with the Utah Department of Natural Resources, Division of Water Rights, conducted this study. The scope of 


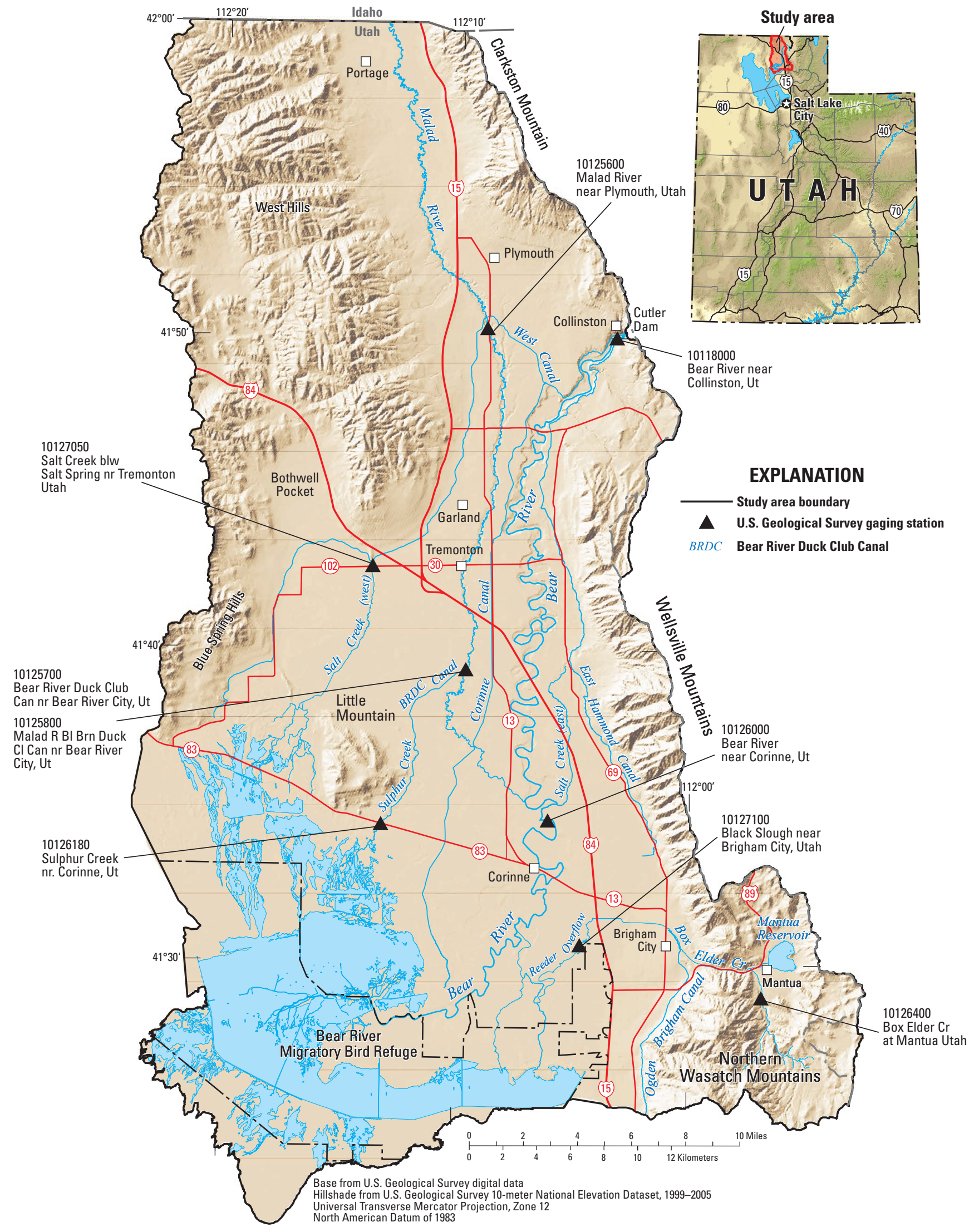

Figure 1. Location of Malad-Lower Bear River study area and U.S. Geological Survey streamflow gaging stations. 
the study included reassessing the hydrologic system to determine if changes have occurred since the previous study in the 1970s (Bjorklund and McGreevy, 1974), refining the groundwater budget, creating a numerical groundwater flow model, and using the model to analyze the effects of groundwater withdrawals on surface water.

The purpose of this report is to present an analysis of hydrologic conditions in 2013 and compare the conditions to those in the 1970s; present an average annual groundwater budget with details of locations and amounts of recharge and discharge; and present the construction, calibration, and use of the numerical groundwater flow model. Creating the numerical model requires more detail than previously described (Bjorklund and McGreevy, 1974), and the report presents tables detailing water-budget components. The report also presents maps showing the model-simulated reduction in groundwater discharge to surface-water features caused by groundwater withdrawals. The maps provide guidance on how much certain locations of withdrawal affect different surfacewater features, and may aid in future decisions relating to development of groundwater resources.

\section{Description of the Study Area}

The study area is located in the northeastern corner of the Basin and Range physiographic province (Fenneman, 1931) and covers about 800 square miles $\left(\mathrm{mi}^{2}\right)$ within the Utah portion of Hydrographic Area 273 (fig. 1; Harrill and Prudic, 1998). The mountainous areas are mostly undeveloped, are used for grazing and recreation, and range in altitude from 6,000 to 10,000 feet (ft). The valley is dominated by irrigated and non-irrigated cropland, but also includes residential, commercial, and industrial areas. The southern end of the valley includes the Bear River Migratory Bird Refuge, other wetlands, open water, and playas. Valley altitudes range from $4,200 \mathrm{ft}$ in the south to $5,200 \mathrm{ft}$ at the Utah-Idaho state line.

\section{Climate}

The climate is humid continental in the valley and eastern mountains, and transitions to steppe in the west (Wahlquist, 1981). Average valley precipitation (1949-2011) is 15.1 inches per year (in/yr) and ranges between 8 and $28 \mathrm{in} / \mathrm{yr}$ (fig. 2). Most precipitation occurs during winter and early spring as snowfall. Monsoonal rainfall occurs during late summer and early fall. Precipitation statistics are based on Western Regional Climate Center records from 1948-2012 for Brigham City, Corinne, Cutler Dam, Garland, Plymouth, Thiokol (west of study area), and Tremonton, and averaged to account for variations within the study area. During the period of record, there was a slightly decreasing trend in annual precipitation from 1965 to 2010.

\section{Surface Water and Springs}

The Bear and Malad Rivers enter the study area near Collinston and Portage, respectively (fig. 1). They are the largest streams in the study area, and the combined average flow into the study area is about 1,100,000 acre-ft/yr as shown in the following table. In addition, about 240,000 acre-ft/yr enter the study area near Collinston via the West Canal and East Hammond Canal (fig. 1) that in turn, distribute water to a network of canals and ditches for irrigation. A large portion of the Malad River also is diverted at the Bear River Duck Club Canal (U.S. Geological Survey gage 10125700) to supply water to wetland and wildlife areas north of Great Salt Lake (fig. 1).

The combined flow of the Bear and Malad Rivers at the most downstream gages in the study area (station numbers 10126000 and 10125700) is about 1,200,000 acre-ft/yr. No perennial streams enter the rivers, indicating that runoff in the study area is minimal. The increase in flow in rivers through the study area is from irrigation return flow, springs near the channels, field drains that discharge to the channels, and groundwater discharge directly to the rivers.

No perennial streams originate from the western side of the Wellsville Mountains north of Brigham City (fig. 1) and there is little physical evidence of ephemeral runoff. The steep topography and narrow width of the Wellsville Mountains results in a relatively small zone where seasonal precipitation exceeds infiltration, which is a possible reason for limited surface-water runoff. Box Elder Creek starts in the mountains east of Brigham City, but most of the flow is derived from large springs near Mantua (fig. 1). South of Brigham City, small perennial streams flow from the western side of the Northern Wasatch Mountains. The Blue Spring Hills and West Hills in the western portion of the study area are semi-arid, lower elevation mountains that generate minor amounts of runoff and perennial surface water.

Springs are also an important part of the hydrology and water rights in the study area. Most springs occur in or along the base of the Wellsville Mountains, but some occur in the more central and western parts of the area (see "Springs" section of this report). Many contribute flow to the Bear River, are used for municipal water supply, or contribute to wetland areas.

\section{U.S. Geological Survey gaging stations on Bear and Malad Rivers}

\begin{tabular}{|c|c|c|}
\hline $\begin{array}{l}\text { Station name and number } \\
\text { (from USGS National Water Information System) }\end{array}$ & $\begin{array}{l}\text { Period of } \\
\text { record }\end{array}$ & $\begin{array}{c}\text { Average } \\
\text { annual flow } \\
\text { (acre-feet } \\
\text { per year) }\end{array}$ \\
\hline Bear River near Collinston, Ut (10118000) & 1964 to 2010 & $1,060,000$ \\
\hline Bear River near Corinne, Ut (10126000) & 1964 to 2010 & $1,200,000$ \\
\hline $\begin{array}{l}\text { Malad River at Woodruff, ID (Located } 2 \text { miles } \\
\text { north of study area boundary) (10125500) }\end{array}$ & 1965 to 1980 & 51,000 \\
\hline Malad River near Plymouth, Utah (10125600) & 1965 to 1980 & 60,000 \\
\hline Malad River near Plymouth, Utah (10125600) & 1965 to 1973 & 49,000 \\
\hline $\begin{array}{l}\text { Bear River Duck Club Can nr Bear River } \\
\text { City, Ut (10125700) }\end{array}$ & 1965 to 1973 & 38,000 \\
\hline $\begin{array}{l}\text { Malad R Bl Brn Duck Cl Can nr Bear River } \\
\text { City, Ut (10125800) }\end{array}$ & 1965 to 1973 & 32,000 \\
\hline
\end{tabular}




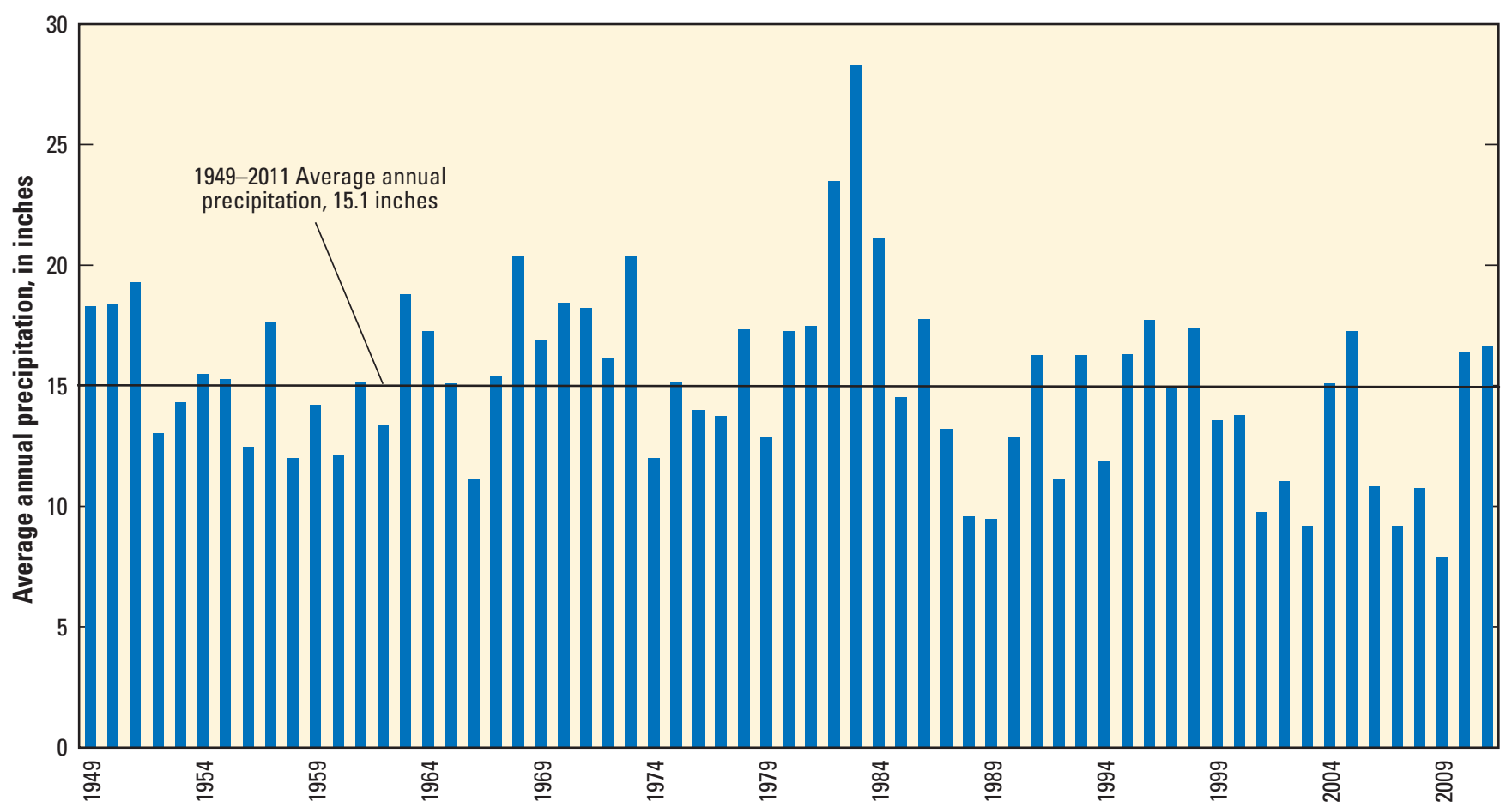

Figure 2. Average annual precipitation measured at Brigham City, Corinne, Cutler Dam, Garland, Plymouth, Thiokol, and Tremonton, for the period 1949-2011, Malad-Lower Bear River study area.

\section{Agricultural Land Use}

In addition to urban and residential areas, the study area contains about 160,000 acres of agricultural land, of which about 80,000 acres are irrigated (fig. 3). With the exception of about 3,500 acres in Bothwell Pocket, and other small isolated areas, surface water is used for all irrigation. Buried field drains, dating back to the early 1900s, underlie large parts of the irrigated areas (fig. 4). The field drains lower the water table, flush salts from the soil structure, expand the range of arable land, and convey groundwater to rivers and other areas of discharge.

\section{Groundwater Development}

Unlike many populated Utah valleys, groundwater development is a minimal part of the hydrologic system in the study area. Much of the municipal water supply is obtained from springs and most of the irrigation supply is obtained from surface water. Municipal and industrial wells withdraw about 7,400 acre-ft/yr from wells, and withdrawals have increased only about 100 acre-ft/yr from the late 1970 s to the early 2010s (see "Well Withdrawals" section of this report). Irrigation well withdrawals occur mainly in the Bothwell Pocket area and near the mountain front south of Brigham City. Irrigation withdrawals depend on climatic conditions and vary annually, but overall long-term irrigation pumping has remained relatively constant from 1976 to 2013 at about $4,000 \mathrm{acre}-\mathrm{ft} / \mathrm{yr}$.

\section{Hydrogeology}

Groundwater occurs in the consolidated rock in the mountains and in the basin fill of the valley. The basin fill and the underlying and adjacent consolidated rock are considered parts of a single groundwater flow system. The mountains consist mainly of Precambrian- and Paleozoic-age sedimentary rocks that include fractured quartzite and carbonates. Sweetkind and others (2011) provide descriptions of the lithology, permeability, and thicknesses of hydrogeologic units within the study area. Primary permeability of the consolidated rock is generally low, but secondary permeability, created by fracturing or solution openings, can be high (Bjorklund and McGreevy, 1974, table 4). Hurlow (1999, p. 4) also noted that secondary permeability may be a factor in controlling groundwater occurrence and movement in the consolidated rock.

The valley is down-dropped in response to Basin and Range extension, and is underlain by the same consolidated rocks exposed in the adjacent mountains. The basin is filled with unconsolidated, semi-consolidated, and consolidated materials eroded from the mountains. Numerous cycles of inundation and desiccation of Quaternary-age lake sediments (Currey and others, 1984) have reworked the basin fill and shaped the valley bottom. The deepest and oldest basin fill comprises the semi-consolidated to consolidated late Tertiary Salt Lake Formation (Anderson and others, 1994, p. 7). Shallower and younger basin-fill deposits consist of alluvium derived from the adjacent mountains, and lacustrine sediments associated with Lake Bonneville (Bjorklund and McGreevy, 1974, table 4; Hugh Hurlow, Utah Geological Survey, 


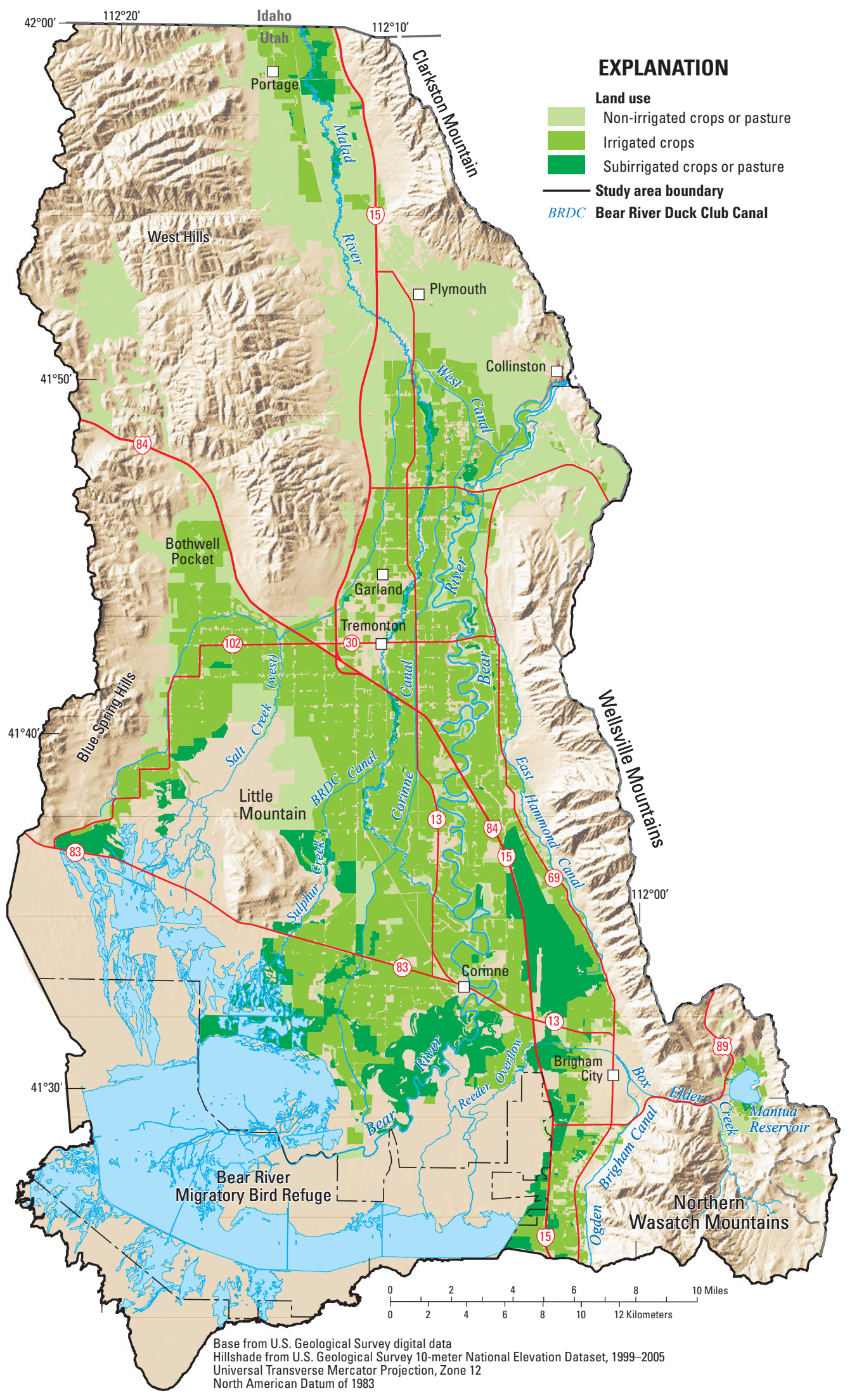

Figure 3. Distribution of agricultural lands, Malad-Lower Bear River study area. 


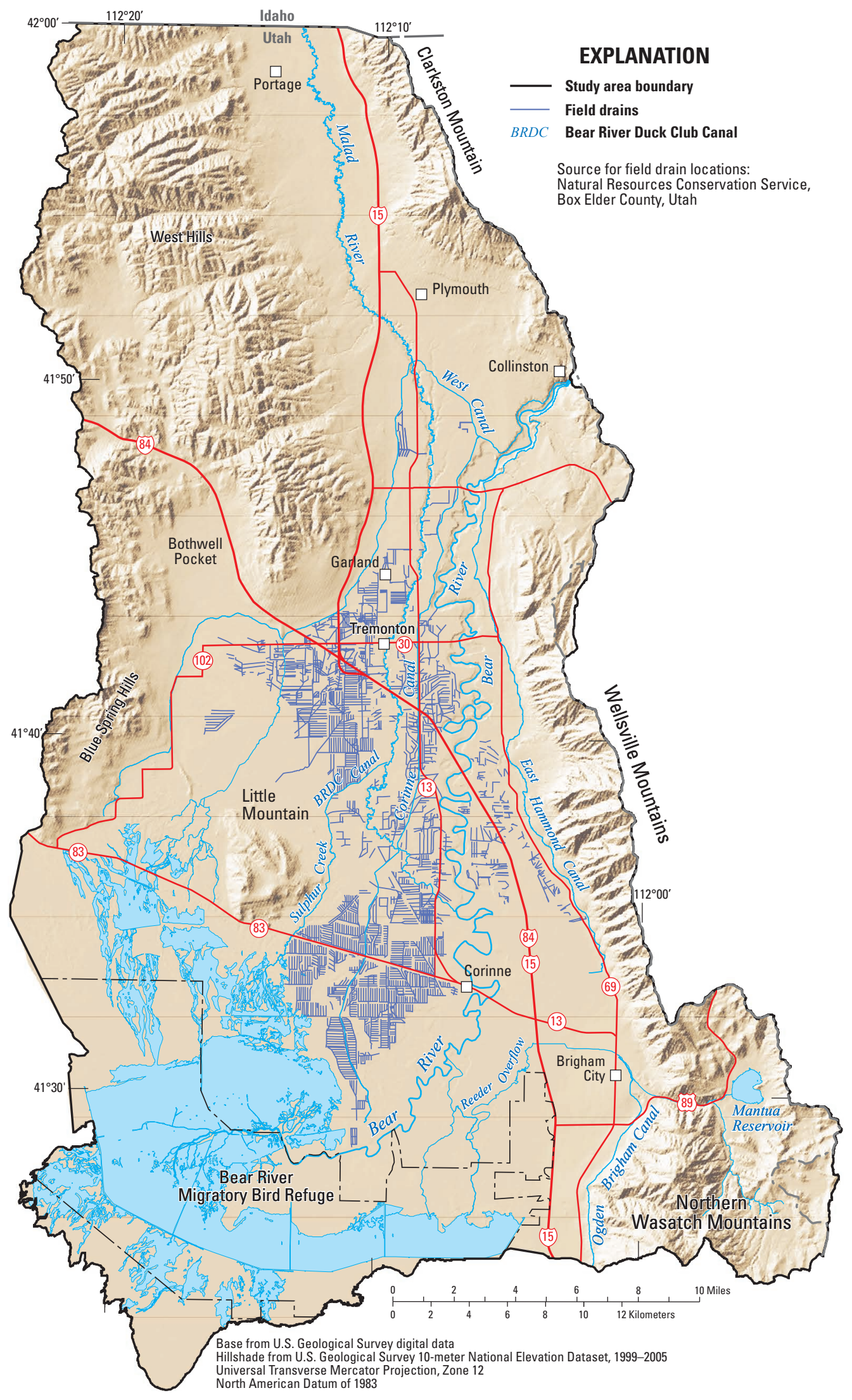

Figure 4. Location of known field drains, Malad-Lower Bear River study area. 
written commun., February 2016). The estimated thickness of unconsolidated basin-fill deposits ranges from $600 \mathrm{ft}$ near Tremonton (Anderson and others, 1994, p. 13) to greater than $3,000 \mathrm{ft}$ south of State Highway 83 (Cederberg and others, 2011, fig. A1-4). Transmissivity, as estimated by aquifer tests, ranges from 2,000 to 140,000 $\mathrm{ft}^{2} / \mathrm{d}$ (Bjorklund and McGreevy, 1974, table 5).

Bjorklund and McGreevy (1974, table 4) describe the basin fill as interbedded, poorly to well sorted deposits of clay, silt, sand, gravel, cobbles, and boulders. Grain size grades laterally to finer deposits in the valley center. Wallace and others (2010, p. 12) determined that in the Bothwell Pocket area, the basin fill consists of coarse-grained alluvial fan marginal deposits that grade into fluvial or fluvial-lacustrine fine-grained deposits, and that clay layers are discontinuous. Anderson and others (1994, fig. 3) show the concept of discontinuous deposits in and near the study area. Inkenbrandt and Lachmar (2012, fig. 2) show similar gradation and discontinuity of layers for Cache Valley, east of the study area. The presence of clay, whether in layers or in discontinuous lenses, increases vertical anisotropy of the basin fill as a ratio of horizontal-to-vertical conductivity. Ratios of horizontal-to-vertical hydraulic conductivity usually are 2 to 10 for alluvium, but can be up to 100 or greater where clay layers are present (Todd, 1980, p. 81).

\section{Hydrologic Conditions}

Hydrologic conditions in this report refer to streamflow, irrigation diversions and application, land use, precipitation, groundwater levels, groundwater discharge to rivers, and groundwater discharge to springs. The assessment of longterm hydrologic conditions was achieved by comparing current conditions to those described in the 1970s (Bjorklund and McGreevy, 1974). Assessment of long-term hydrologic conditions is important for a general understanding of the study area and to verify that a steady-state numerical model will sufficiently simulate the conditions of the study area. Short-term changes in the hydrologic system provide insight into how components of the hydrologic system are interrelated.

\section{Long-Term Consistency}

Because the hydrologic system is dominated by surface water and irrigation, changes in the application of surface water or in land use could have large effects on the hydrologic conditions. Surface-water diversions and land use appear stable from the 1960s to the 2010s. Diversions from the Bear River to West Canal and East Hammond Canal (fig. 1) for 1961-2013 averaged about 240,000 acre-ft/yr; for most years the total diversion varied by less than 11 percent from the 1961-2013 average (table A1-11). Irrigated areas reported by State of Utah Water Related Land Use maps for 1986,
1996, 2003, and 2009 varied by less than 15 percent from the average (table A1-2). Little change in diversions or irrigated acreage indicates that recharge from irrigation or in tailwater contributions to surface water has probably been fairly consistent.

With the exception of the early 1980s, average annual precipitation has decreased slightly from 1965 to 2010 (fig. 2; Western Regional Climate Center, 2012). It is possible this could cause a downward trend in groundwater recharge, groundwater discharge to springs and rivers, or a decrease in groundwater levels. These possible effects have not been detected.

In addition to examining components of the hydrologic system (irrigation and precipitation) that could produce changes in the groundwater system, indicators of change in the groundwater system were also investigated. First, changes in groundwater levels as measured in wells were examined. Changes in water levels were calculated for 24 wells measured in 1971 (Bjorklund and McGreevy, 1973, table 3) and in 2013 (fig. 5, table A1-1). Additional wells measured in 1971 could not be found, had been destroyed, or were no longer accessible for measurements. Water levels for each year were compared graphically in box plots (fig. 6) and by using the MannWhitney statistical analysis for non-normally distributed data (Mann and Whitney, 1947). Results indicate with 96-percent confidence that measured levels in 2013 are essentially the same (no statistical difference) as they were in 1971 (MannWhitney $\mathrm{U}=285, \mathrm{n}_{1}=\mathrm{n}_{2}=24, \mathrm{P}<0.01$ two-tailed). Water levels in five wells that have been measured more frequently show little long-term change throughout the valley (fig. 7).

In areas with significant groundwater discharge, it is possible for groundwater discharge to decrease without a noticeable change in water levels. To determine if this is occurring, discharge to the Bear and Malad Rivers through time was examined. The difference in flow of the Bear River between Collinston and 39 mi downstream near Corinne (fig. 1) was examined over the 1965-2010 period using data from USGS streamflow gaging stations 10118000 and 10126000 (http://waterdata.usgs.gov). The difference in streamflow between the two gages incorporates hydrologic processes that contribute inflow to the Bear River, including discharge from groundwater, discharge from field drains, irrigation return flow, and surface-water inflows. The difference between the gages also incorporates outflow between the two gages, but this is negligible. Trends in the difference are best illustrated by using the cumulative difference between the gages (fig. 8). An increase in slope indicates an increase in discharge to the Bear River between the two gages. A decrease in slope indicates a decrease in discharge to the river between the two gages. The relatively constant slope of the cumulative difference curve from 1965 to 2010 indicates that, other than changes caused by precipitation variability, little has changed in the system. 


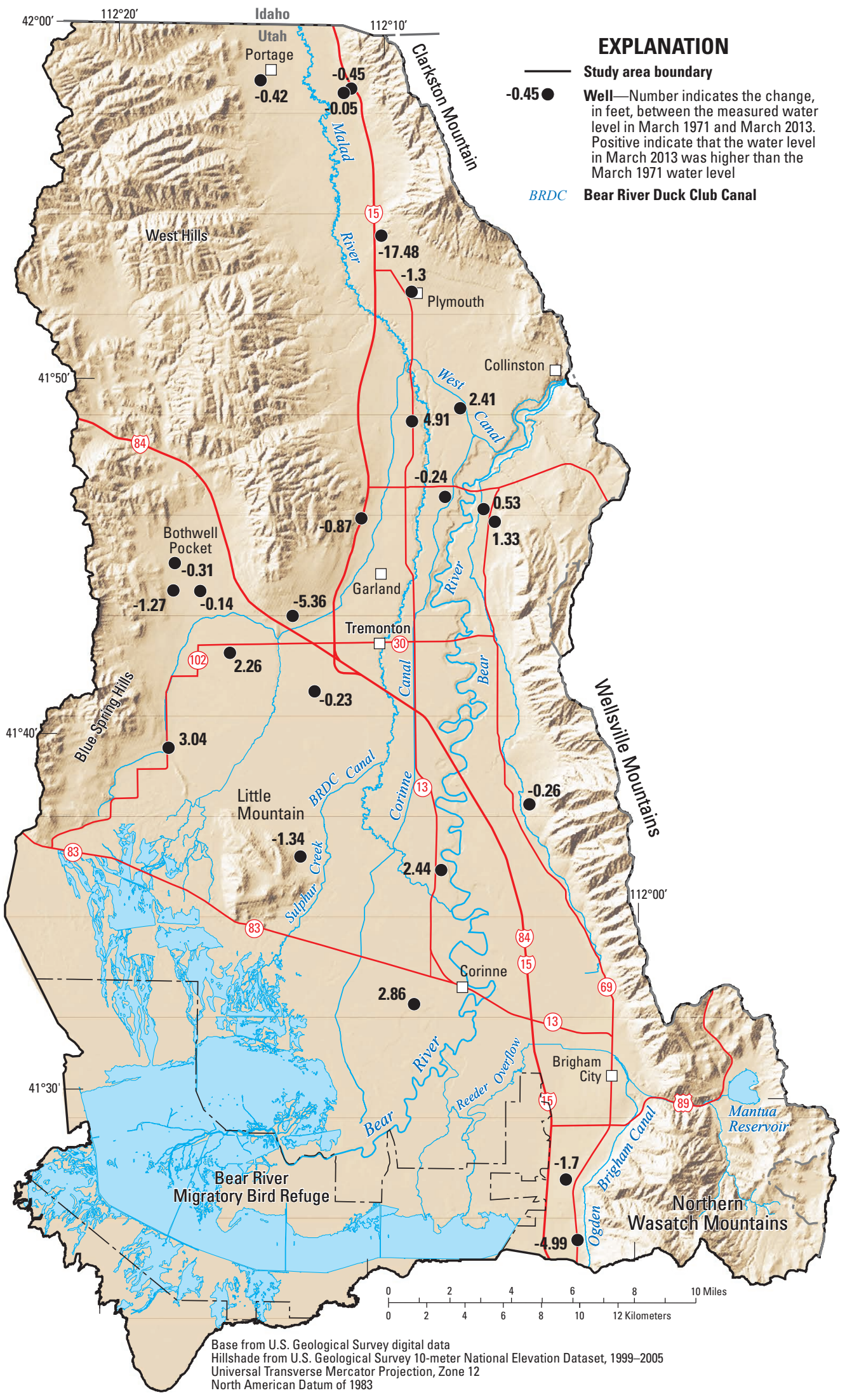

Figure 5. Location of wells and changes in measured water levels from 1971 to 2013, Malad-Lower Bear River study area. 


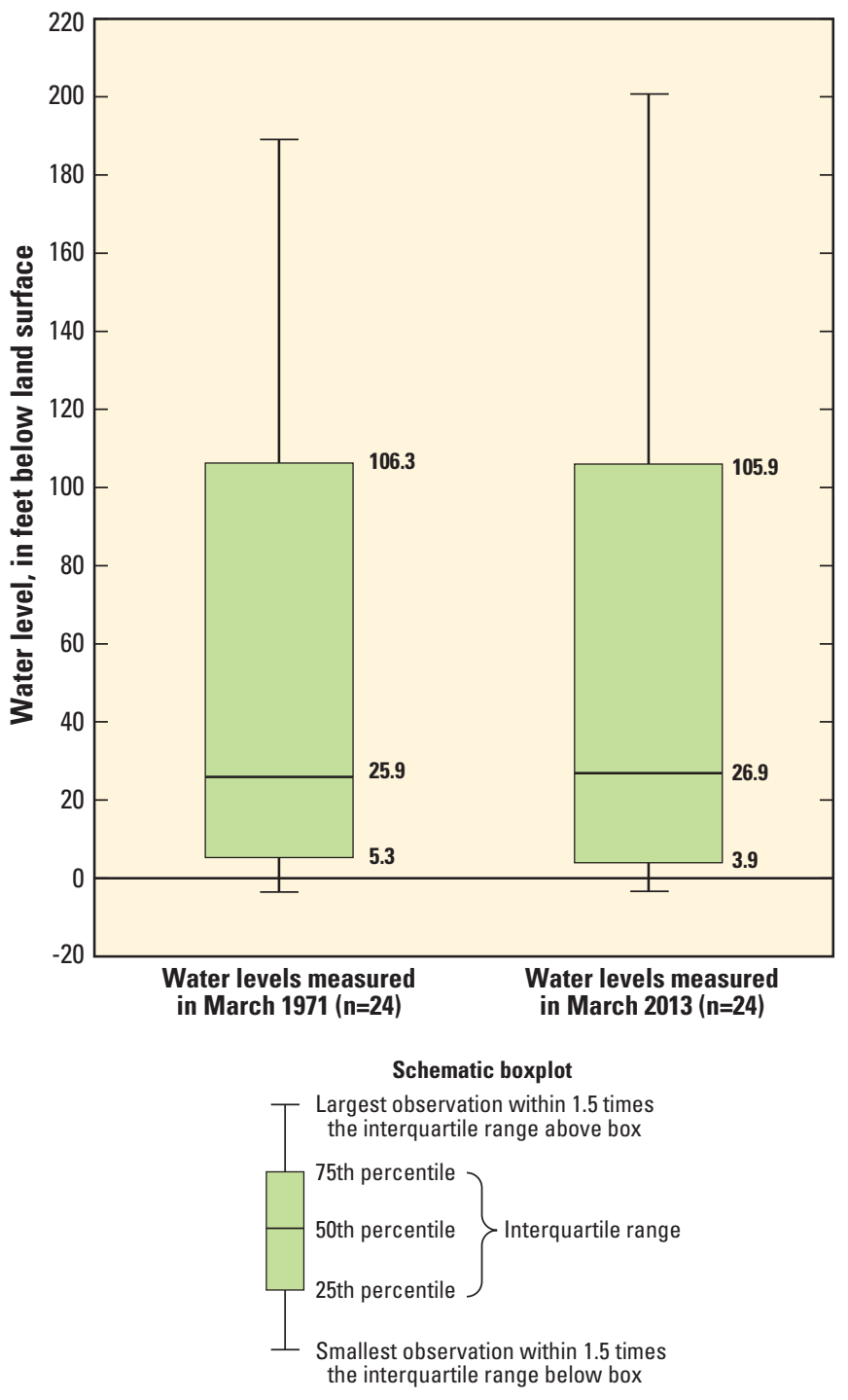

Figure 6. Water levels measured in selected wells in March 1971 and March 2013, Malad-Lower Bear River study area.
Because streamgages on the Malad River have been discontinued, an analysis of the cumulative difference between gages for the 1965-2010 period is not possible. Seepage assessments (appendix 2) indicate, however, that the 25 cubic feet per second $\left(\mathrm{ft}^{3} / \mathrm{s}\right)$ gain in streamflow measured in September 2012 between Plymouth, Utah, and the Bear River Duck Club Canal diversion was similar to the annual gaged difference of $28 \mathrm{ft}^{3} / \mathrm{s}$ in 1965-73. A seepage assessment in August 1971 (McGreevy, 1972) for the same reach of the Malad River showed a gain of $29 \mathrm{ft}^{3} / \mathrm{s}$. Given streamflow measurement uncertainty and variations in antecedent conditions, it can be assumed that the gain along this reach of the Malad River has remained constant from the mid-1960s to 2010s.

Groundwater discharge to the Bear and Malad Rivers, springs that flow into the rivers, and field drains that flow into the rivers are a major part of the groundwater budget (table 1). The consistency of the gain in the rivers indicates that the groundwater system in general, is about the same in the 2010s as in the mid-1960s. Little data and seasonal variability prevented comparison of individual spring discharges between the two periods.

\section{Short-Term Fluctuations}

Although long-term hydrologic conditions have remained stable, both groundwater and surface water fluctuate at shorter time scales. A clearly defined period of higher water levels from the early 1980s to 1990 (fig. 7) was caused by above average precipitation from 1980-84 (fig. 2). Water-level fluctuations in the 1990s through 2010s are similar to the precipitation variability. Seasonally, water levels in the valley are highest in summer in response to surface-water irrigation.

Differences in streamflow between the Bear River at Collinston and Corinne show a pattern that is similar to the variability in precipitation (fig. 8) and water levels (fig. 7). Streamflow differences increase during wet years, when groundwater levels are higher, and decrease during dry years, as water levels decline. Examples of the correlation between streamflow differences and precipitation are shown by increasing precipitation and increased streamflow differences during the early 1980 s and decreasing precipitation and decreased streamflow differences from the mid-2000s to the 2010s. 


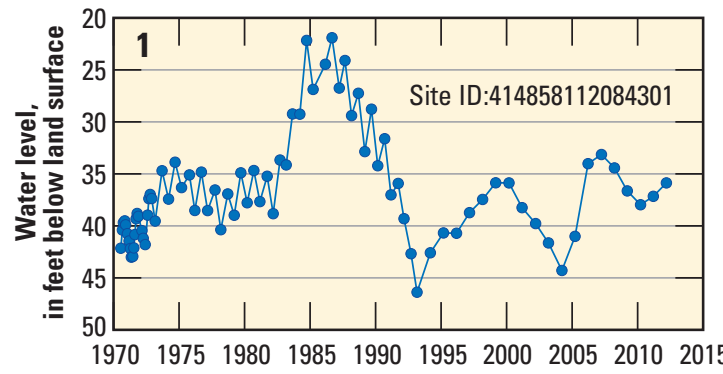

EXPLANATION

10 Hydrograph site and number

$B R D C$ Bear River Duck Club Canal

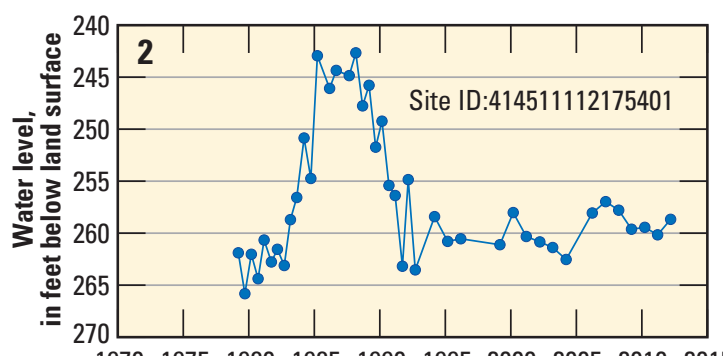

$19701975 \quad 19801985199019952000200520102015$
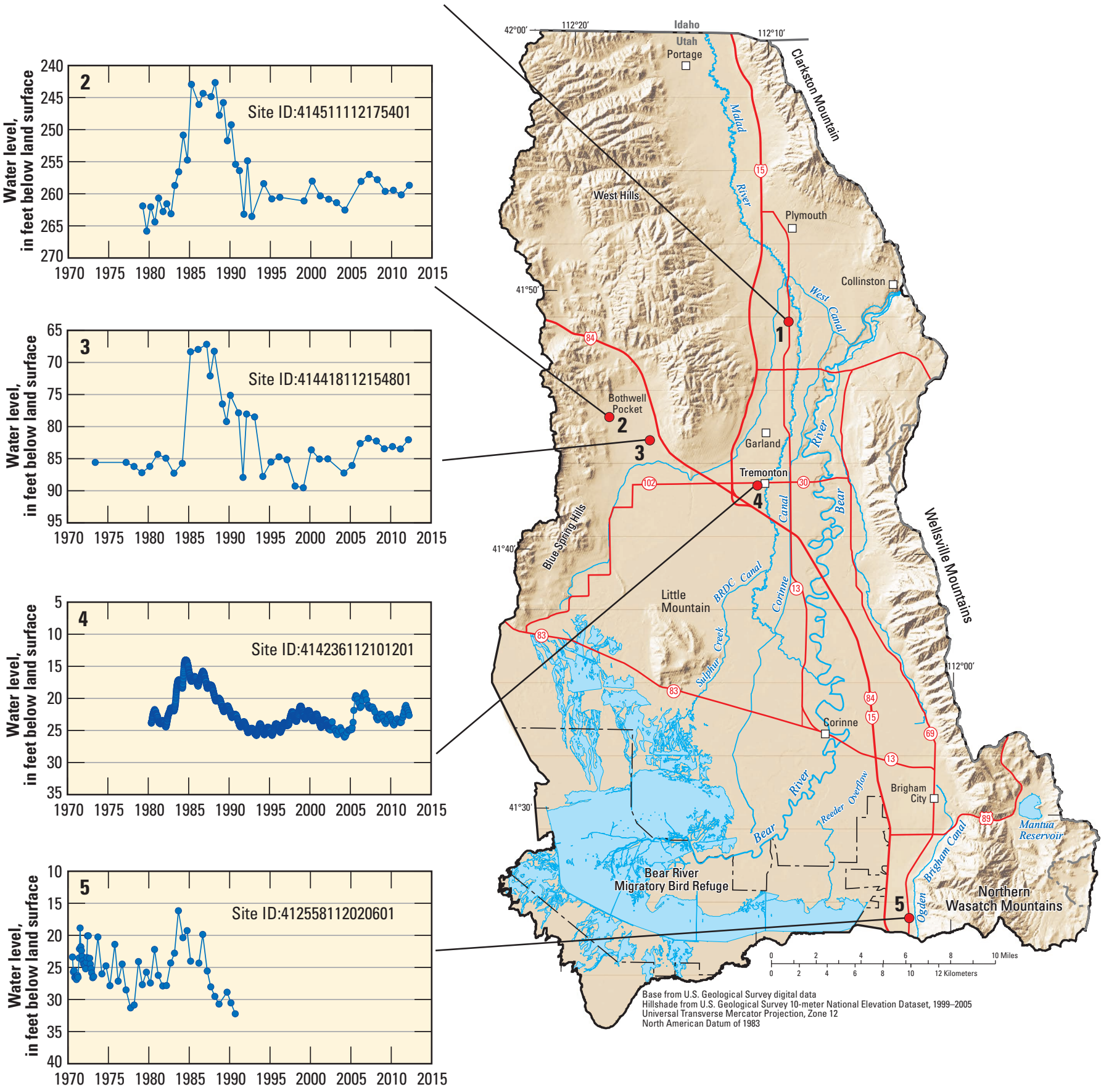

Figure 7. Annual water-level fluctuations in selected wells from 1971 to 2013, Malad-Lower Bear River study area. 


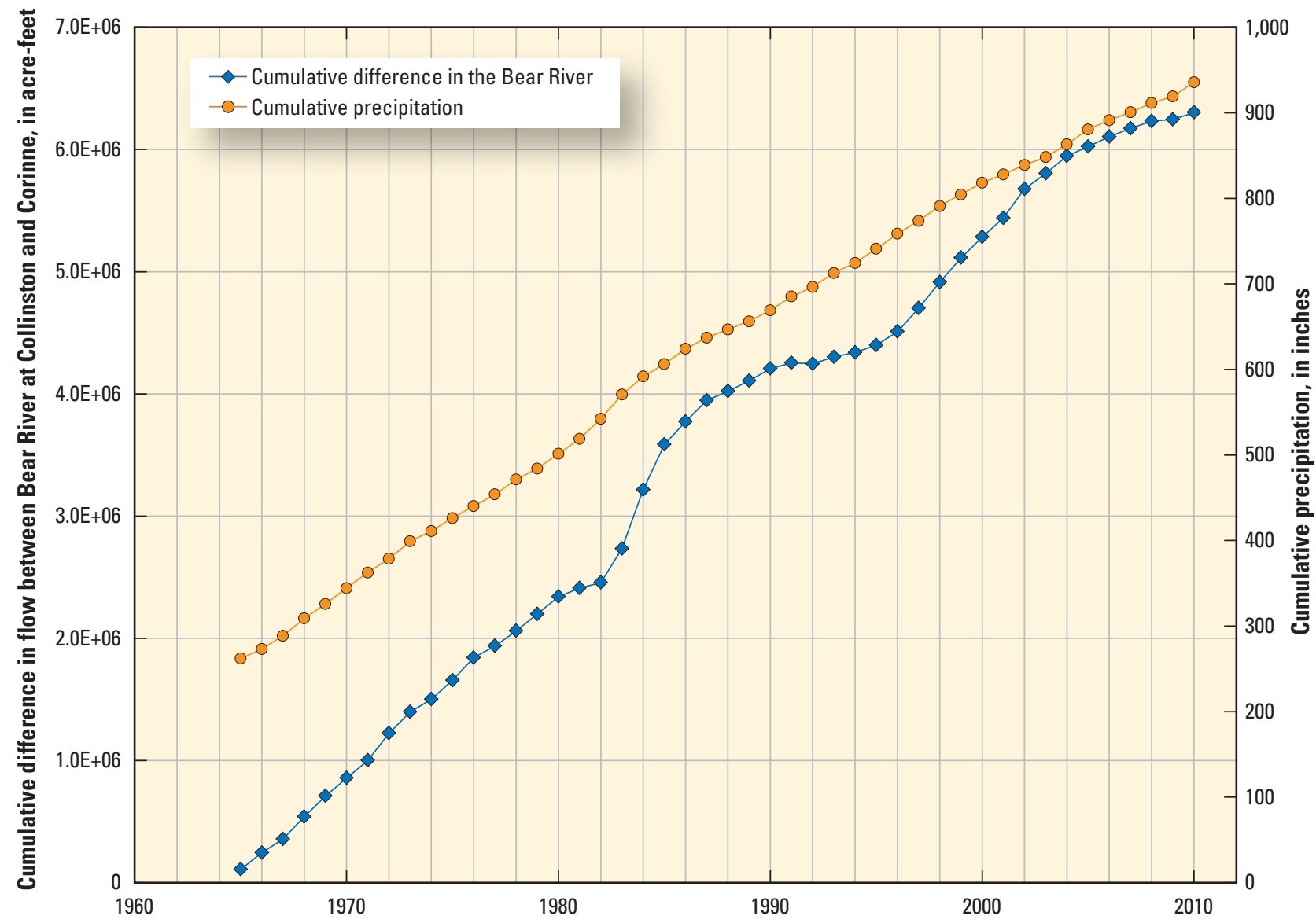

Figure 8. Cumulative difference in flow between the Bear River at Collinston and Corinne, and cumulative precipitation, Malad-Lower Bear River study area. 


\section{Conceptual Groundwater Model}

The conceptual model of the groundwater flow system in the Malad-Lower Bear River Area is illustrated in figure 9. The mountains and valley are considered part of the same groundwater system, and groundwater that is recharged from precipitation in the mountains moves through consolidated rock to the basin fill. Recharge occurs in the valley from irrigation. Discharge occurs to rivers, springs and diffuse seepage areas, evapotranspiration, wells, and field drains.

The general direction of groundwater movement within the study area is from the mountains to the valley and then southward toward Great Salt Lake. The potentiometric map of Bjorklund and McGreevy (1974, pl. 2) shows steep hydraulic gradients along the eastern mountain fronts, converging groundwater flow paths to the Bear and Malad Rivers, and water levels near or above land surface in the southern areas. Groundwater movement in 2013 is similar to that in 1971 (see "Hydrologic Conditions" section of this report).

Irrigation and field drains have changed hydrologic conditions within the study area since the development of extensive surface-water irrigation in the early 1900s. Recharge from irrigation between the Malad and Bear Rivers has resulted in a groundwater divide centered on the Corinne Canal (Bjorklund and McGreevy, 1974, pl. 2), and increasing groundwater discharge to the Malad River. Recharge from irrigation west of the Malad River also contributes discharge to the river. Future changes in land use and the amount and distribution of irrigation may affect groundwater movement to and from the Malad River.

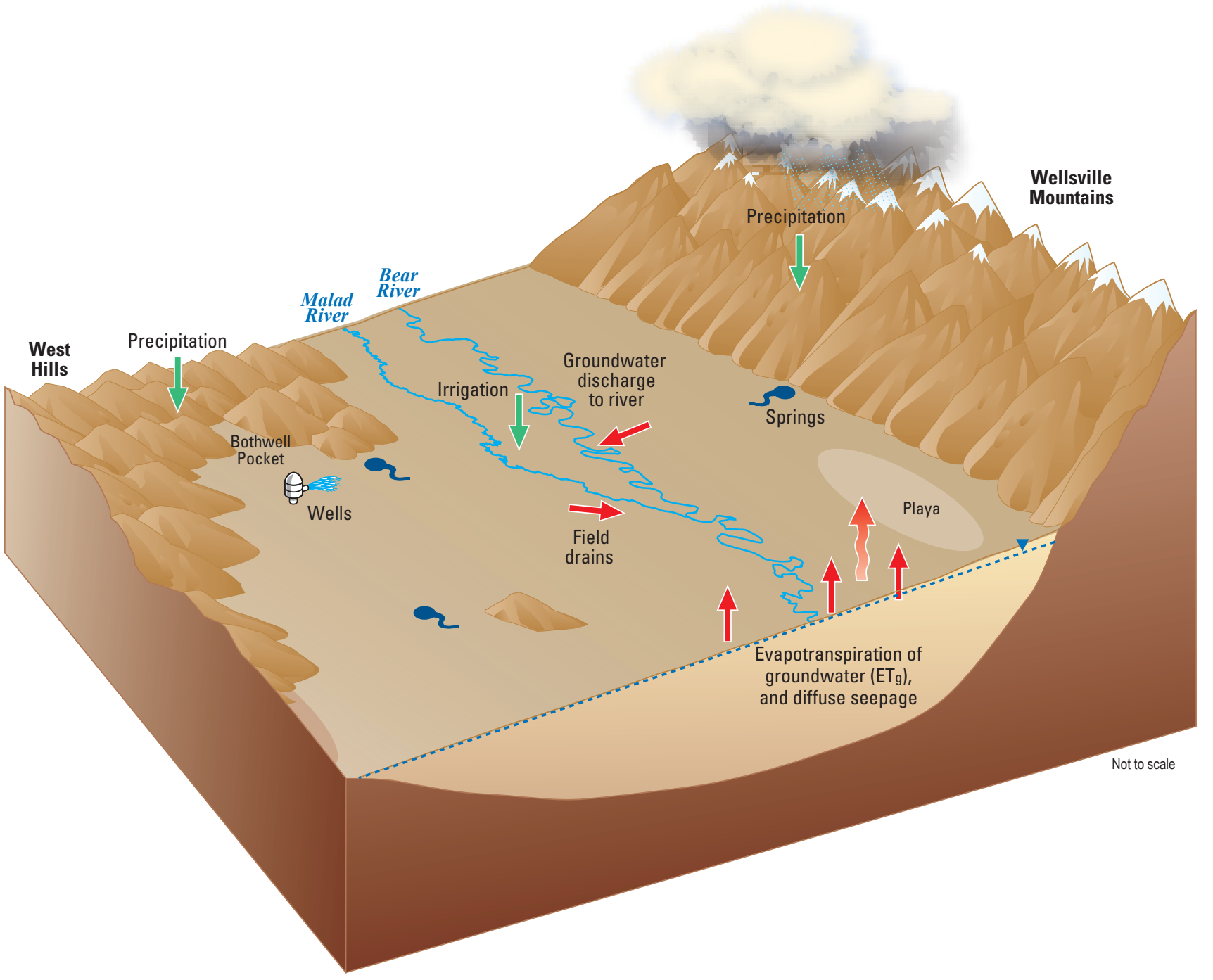

Figure 9. Conceptual groundwater system, Malad-Lower Bear River study area. 


\section{Groundwater Budget}

Although the groundwater system in the study area does not appear to have changed significantly from 1971 to 2013, a new groundwater budget was developed as part of this project (table 1). Methods for estimating recharge have changed since the last budget was prepared (Bjorklund and McGreevy, 1974), and the longer period of record for gaging stations on the Bear River and additional measurements on the Malad River allow for more certainty in a major component of groundwater discharge. Additionally, a more detailed budget was required for model construction, calibration, and simulation of groundwater development on surface-water features. Recharge and discharge estimates do not include the wetlands, playas, and open water adjacent to Great Salt Lake that are west of Interstate 15 and south of Highway 83 (fig. 1). Minimal groundwater movement was assumed in that area because of (1) increasing amounts of fine-grained lacustrine basin fill, (2) no identified springs, (3) ample surface water to meet the water demands of crops and natural vegetation, and (4) no statistically significant groundwater gain along the Bear River south of Highway 83 (table A2-2).

The groundwater budget presented in this report is about two-thirds of the budget estimated by Bjorklund and McGreevy (1974, p. 16). The difference does not reflect a change in hydrologic conditions, but rather an improvement in individual budget components because of additional streamflow data, better estimates of groundwater discharge, and more detailed estimates of groundwater recharge from precipitation and irrigation.

Average annual groundwater recharge to and discharge from the groundwater flow system are estimated at 164,000 and 228,000 acre-ft/yr, respectively. The imbalance between recharge and discharge represents uncertainties resulting from system complexities and incomplete data, and the possibility of groundwater inflow from surrounding basins that cannot be directly measured. Individual budget components are estimated on the basis of available data, with no assumption that independent calculations of discharge and recharge would equal. The imbalance does not represent declines in groundwater storage, nor change the interpretation of stable hydrologic conditions during the 1965-2010 time period.

Each element of the groundwater budget is assigned a qualitative uncertainty of low (about 10 percent), moderate (about 20 percent), and high (greater than 30 percent). The uncertainty assigned to a budget component is a function of the availability and quality of data, complexity of computations, and degree of temporal interpolation and extrapolation. For groundwater discharge, spring discharges are directly measured, but the relatively limited data does not fully describe temporal flow variability. Long-term surface-water

Table 1. Average annual groundwater budget, Malad-Lower Bear River study area.

[Units in acre-feet per year]

\begin{tabular}{|c|c|c|}
\hline Budget component & Amount & Uncertainty $^{1}$ \\
\hline \multicolumn{3}{|c|}{ Recharge } \\
\hline Precipitation $^{2}$ & 82,000 & high \\
\hline Irrigation $^{3}$ & 82,000 & moderate \\
\hline Other recharge ${ }^{4}$ & unknown & \\
\hline Total recharge (rounded) & 164,000 & moderate \\
\hline \multicolumn{3}{|c|}{ Discharge } \\
\hline Bear River $^{5}$ & 74,000 & moderate \\
\hline Malad River ${ }^{5}$ & 21,000 & low \\
\hline Diffuse seepage $^{6}$ & 22,000 & high \\
\hline Evapotranspiration ${ }^{7}$ & 26,000 & moderate \\
\hline Springs $^{8}$ & 74,000 & high \\
\hline \multicolumn{3}{|l|}{ Well withdrawals } \\
\hline Municipal/Industrial & 7,400 & low \\
\hline Irrigation & 4,000 & low \\
\hline Total discharge (rounded) & 228,000 & moderate \\
\hline
\end{tabular}

${ }^{1}$ Uncertainty is a qualitative assessment that incorporates all factors used in the estimation of individual budget components. Low uncertainty indicates errors that are approximately plus/minus 10 percent. Moderate uncertainty indicates errors that are approximately plus/minus 20 percent. High uncertainty indicates errors that uncertainty indicates errors that are approxin
are approximately plus/minus 30 percent.

${ }^{2}$ Details presented in table 2 .

${ }^{3}$ Details presented in table 3 .

${ }^{4}$ Other recharge includes groundwater inflow across the study area boundary.

${ }^{5}$ Details presented in table 5. Discharge to rivers includes all field drains that discharge along the river; therefore, this value aggregates direct groundwater seepage to the river and seepage to the field drain networks that terminate along the river.

${ }^{6}$ Details presented in table 6.

${ }^{7}$ Details presented in table 8 .

${ }^{8}$ Details presented in table 9 . 
data from successive downstream gages represent overall discharge to the rivers; however, ungaged inflows can result in erroneous accounting of individual groundwater fluxes.

Evapotranspiration is estimated for large areas on the basis of generalized land cover; the effects of specific plant types and depths to groundwater are not described. Similarly, estimates of recharge in mountainous areas are calculated from spatially interpolated meteorological data, generalized land cover, and soil characteristics. Given the variations in data and individual budget computations, a rigorous statistical description of uncertainty is not possible.

\section{Recharge}

The sources of recharge are precipitation in the mountains and irrigation in the valley. The large water-level increases in the 1980s and smaller increases during other periods with above-normal precipitation (fig. 7) indicate that recharge from precipitation is a significant source of groundwater. In much of the valley, water levels are highest during the summer months, which validate the concept of valley recharge from irrigation (fig. 7; Bjorklund and McGreevy, 1974, p. 18).

\section{Precipitation}

Groundwater recharge from precipitation is estimated by using the Basin Characterization Model (BCM) developed for the Great Basin carbonate and alluvial aquifer system (Flint and others, 2011). BCM is a distributed-parameter, waterbalance accounting model that computes in-place recharge and surface runoff at a $270-\mathrm{m}^{2}$ grid spacing. Estimates of in-place recharge and surface runoff depend on climatic and physical characteristics that include precipitation, temperature, solar radiation, soil thickness, hydraulic conductivity of the material underlying the soil horizon, vegetation type and density, evapotranspiration rates, and topography. The distribution of BCM in-place recharge and runoff is shown on figure 10. Only a minor amount of in-place recharge from precipitation is estimated in the valley because precipitation rarely exceeds consumptive use of vegetation.

The BCM calculates runoff for each grid cell, but does not accumulate and route runoff. Based on the limited runoff observed in the study area, BCM-calculated runoff is assumed to be consumed by evapotranspiration or to recharge the groundwater system within the same general area for which it is calculated. As in Masbruch and others (2011, p. 86), 30 percent of $\mathrm{BCM}$ runoff is assumed to become groundwater recharge.
Analysis of BCM estimates indicates that in-place recharge plus 30 percent of runoff does not balance the measured discharge of springs along the mountain fronts and gains to the Malad River above irrigation areas. For example, $\mathrm{BCM}$ recharge to the Wellsville Mountains is calculated as $13,200 \mathrm{acre}-\mathrm{ft} / \mathrm{yr}(12,000 \mathrm{acre}-\mathrm{ft} / \mathrm{yr}$ of in-place recharge plus 30 percent of 4,000 acre-ft/yr of runoff). Discharge to springs located along the base of the Wellsville Mountains is approximately 34,000 acre-ft/yr (table 2). The only known source of recharge for these springs is the Wellsville Mountains; thus, a multiplication factor of 2.6 is applied to BCM recharge in this area to obtain the conceptual recharge. Using the same approach, $\mathrm{BCM}$ recharge estimates are adjusted to match local spring discharge throughout the study area (fig. 11, table 2). The multiplication factor is largest in the Wellsville Mountains, possibly because of the steep topography and associated difficulty with extrapolating meteorological inputs and physical parameters used in the BCM. Although the other areas, such as the West Hills, may not have the orographic complexities of the Wellsville Mountains, small errors in the hydraulic permeability of bedrock or amount of precipitation could change the amount of recharge estimated by the BCM. Because of the larger size of these areas, small changes in areal recharge could have significant impacts on the groundwater budget.

These multiplication factors are considered minimums because they are based on matching discharge to specific locations. The analysis does not account for discharge of mountain-derived recharge to the Bear River, most of the Malad River, or diffuse seepage and evapotranspiration of groundwater (ETg) below irrigation areas, because it is not possible to determine how much of the discharge to those features is derived from mountain recharge and how much from valley recharge. For reference, multiplication factors used to match discharge in the Great Basin carbonate and alluvial aquifer system study area vary from 0.29 to 2.25 (Masbruch and others, 2011, fig. D-8).

After adjustments to BCM recharge, the estimated average annual recharge from precipitation in the study area is 82,000 acre feet (acre-ft), 50 percent of the estimated total recharge. Because of the many variables associated with the BCM and because BCM recharge does not appear to be accurate within the study area, recharge from precipitation is considered to have an uncertainty of at least 30 percent. 
$\boldsymbol{A}$

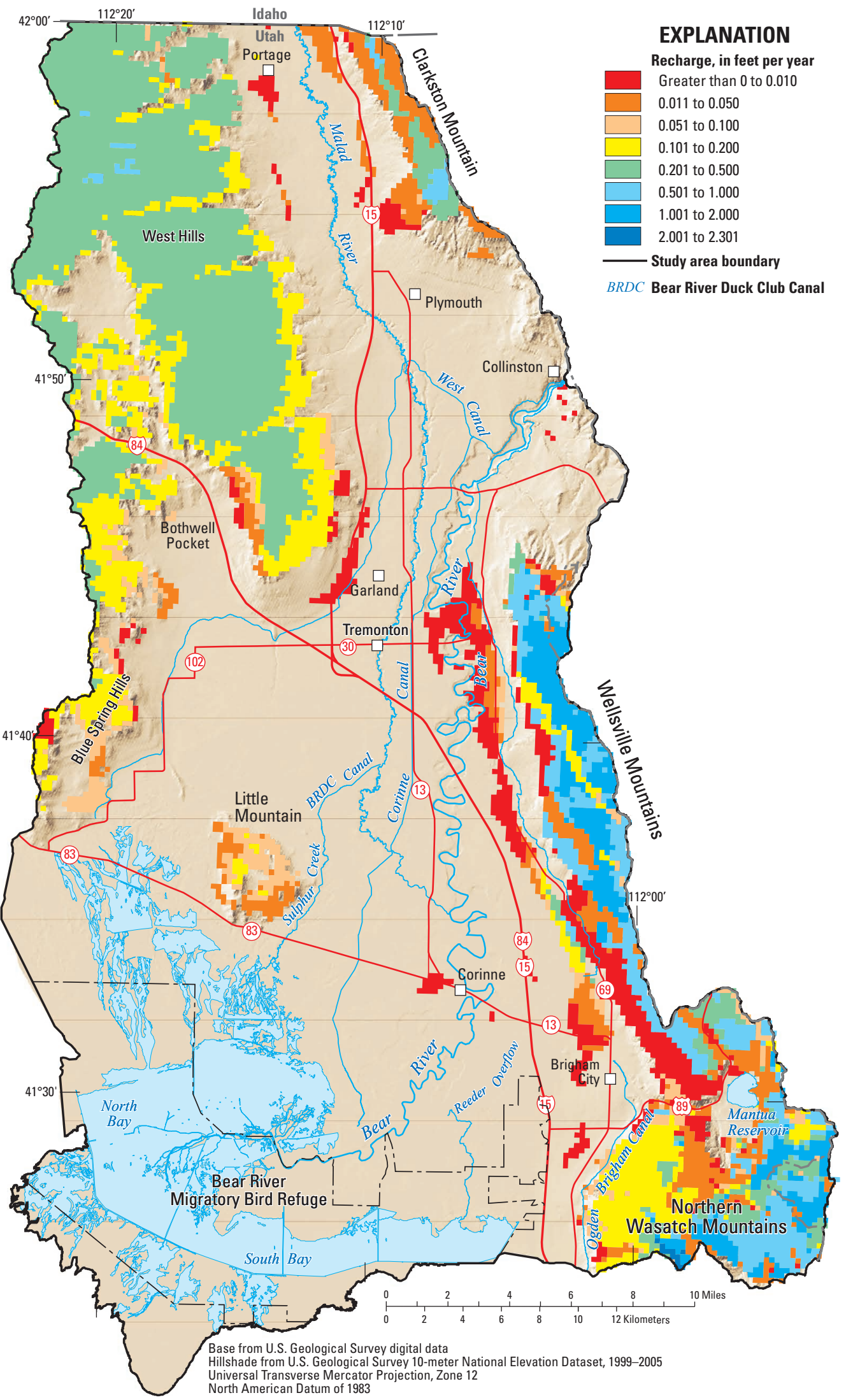

Figure 10. Distribution of average annual 1940-2006 recharge and runoff from the Basin Characterization Model, Malad-Lower Bear River study area. $A$, in-place recharge, and $B$, runoff. 


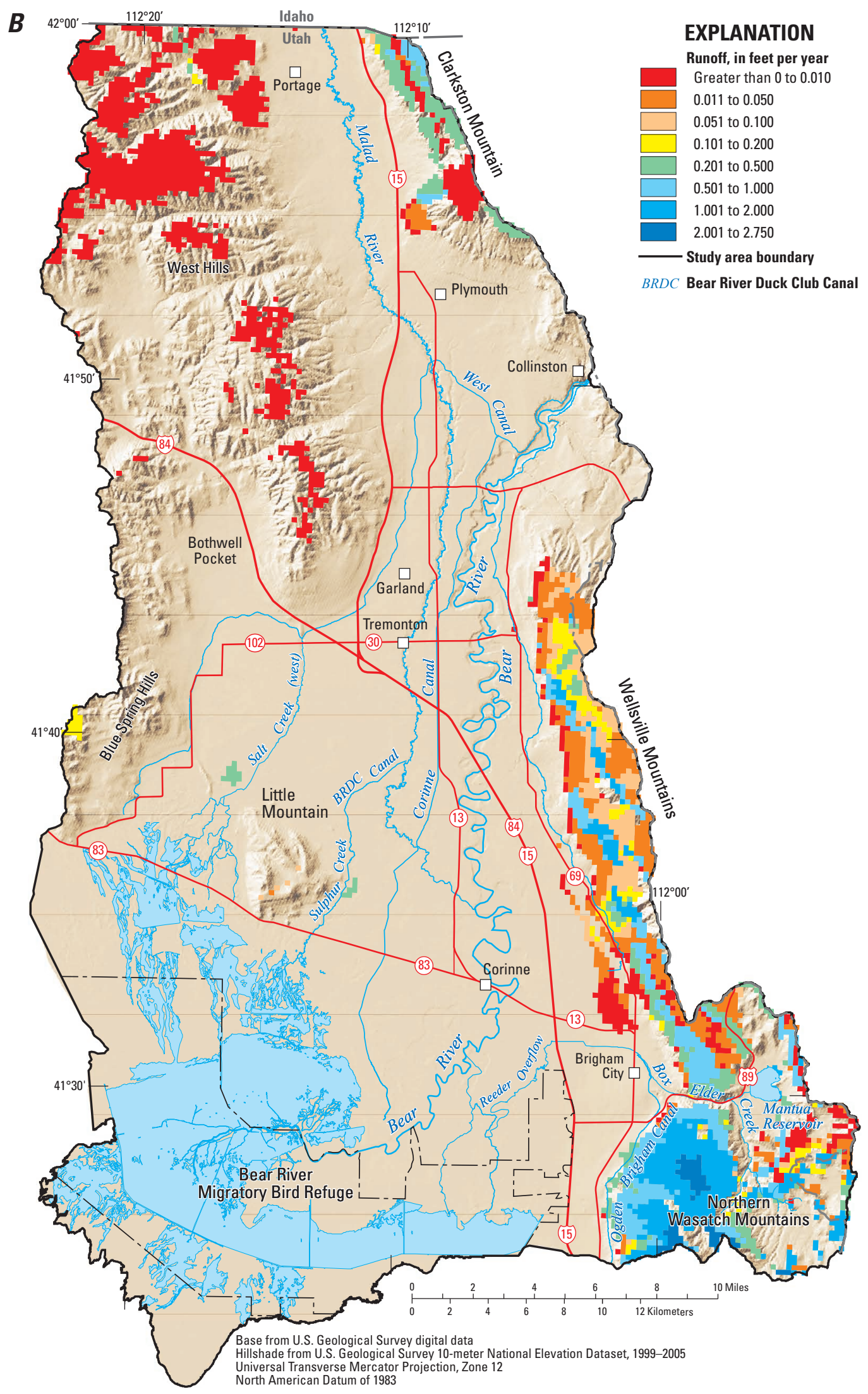

Figure 10. Distribution of average annual 1940-2006 recharge and runoff from the Basin Characterization Model, Malad-Lower Bear River study area. $A$, in-place recharge, and $B$, runoff.-Continued 
Table 2. Groundwater recharge from precipitation, Malad-Lower Bear River study area.

[Units in acres for Area; Units in acre-feet per year for In-place recharge, Recharge from runoff, Associated discharge, and Adjusted recharge; - , unknown]

\begin{tabular}{|c|c|c|c|c|c|c|}
\hline Area $^{1}$ & Area & In-place recharge ${ }^{2}$ & Recharge from runoff ${ }^{2}$ & Associated discharge & Recharge multiplier & Adjusted recharge \\
\hline Wellsville Mountains ${ }^{3}$ & 36,000 & 12,000 & 1,200 & 34,000 & 2.6 & 34,000 \\
\hline West Hills $^{5}$ & 120,000 & 18,000 & 360 & 24,000 & 1.3 & 23,000 \\
\hline Total & & & & & & 82,000 \\
\hline
\end{tabular}

${ }^{1}$ Areas are shown on figure 11.

${ }^{2}$ In-place recharge and Recharge from runoff from Basin Characterization Model (BCM) as published in Buto, 2011, and Masbruch and others, 2011, and shown on figure 10a and $10 \mathrm{~b}$.

${ }^{3}$ Associated discharge for the Wellsville Mountains is diffuse groundwater and field drain discharge to Salt Creek (east) and Black Slough (table 6); evapotranspiration of groundwater from the Salt Creek (east) and Black Slough areas (table 8); and spring discharge to Black Slough, Salt Creek (east), and springs that contribute to the Bear River (table 9).

${ }^{4}$ Associated discharge for the Northern Wasatch Mountains is spring discharge in Mantua Valley (table 9).

${ }^{5}$ Associated discharge for the West Hills is the Malad River from Woodruff to Plymouth (table 5), Salt Creek Springs, and springs near the Malad River (table 9).

${ }^{6}$ Associated discharge for the Blue Spring Hills/Little Mountain area could not be estimated, and the recharge multiplier is set equal to the value used for the northern Wasatch Mountains and West Hills.

\section{Irrigation}

Recharge from irrigation occurs when water available in the root zone exceeds the amount of water consumed by the crop. Water that reaches the root zone is termed "effective applied water," and includes irrigation and precipitation. Effective applied water is less than applied water plus precipitation because of transmission losses, surface runoff as tailwater, and evaporation from the soil and plants. To calculate recharge from irrigation, irrigated lands were subdivided into 10 areas on the basis of the locations of major canals, the Bear and Malad Rivers, topography, and Highway 83 (fig. 12). The Water Related Land Use maps for 1986, 1996, 2003, and 2009 were used to determine the mean acreage of individual crops and total irrigated area within each irrigation area (table 3 ). The amount of water diverted for irrigation was determined from various sources (table 4), including diversion records from 1961 to 2013 for East Hammond Canal and West Canal (U.S. Geological Survey and the Bear River Commission), miscellaneous field measurements, and estimated flow in Corinne Canal (50 percent of West Canal flow; Darin McFarland, oral commun., March 2014).

The amount of irrigation water inflow to the study area minus the surface-water outflow from the area in canals is considered to be applied irrigation; 80 percent of the applied water is assumed to be effective. The remaining 20 percent accounts for general inefficiencies associated with flood irrigation (Mizue, 1968) and is assumed to become tailwater that flows from the fields to ditches, rivers, and wetland areas. The amount of annual effective precipitation for each irrigation area was calculated by using the National Climatic Data Center 30-year normal (1981-2010) for Tremonton, UT (17.03 inches) and multiplying by the size of the irrigated area. As with irrigation, 80 percent of precipitation is considered available for crop consumptive use. The remaining 20 percent is conceptualized as a direct loss of water from the system by evaporation, sublimation, and tailwater runoff. Crop consumptive use is estimated for each area based on local estimates of annual consumptive use for individual crop types provided by
Hill and others (2011; appendix J, p. 58 and 88). Recharge is calculated as the sum of the effective applied irrigation and effective precipitation minus crop consumptive use (table 3 ).

The calculations of recharge from irrigation are modified for several situations. In cases where Water Related Land Use crop types and consumptive-use categories are not the same, representative values of consumptive use are applied as best as possible. For the urban-grass/parks category, it is assumed that no excess watering is applied and zero recharge was assigned; the area represented by this category is small. In the Samaria Lake Canal and Bothwell irrigation areas (fig. 12), crop consumptive use exceeds the estimated applied irrigation, and no recharge was assigned in these areas (table 3). An unknown but small amount of spring and well water is used to irrigate areas north of West Canal near Plymouth, above East Hammond Canal, and in Mantua Valley. Based on the analysis for the Bothwell and Samaria Lake Canal irrigation areas, recharge is assumed to be negligible.

Recharge from irrigation and precipitation on irrigated fields is estimated to be 82,000 acre-ft/yr (table 1). Because of the variables associated with crop type, soil type, and large areas where applied water is assumed to be constant, recharge from irrigation is assumed to have a qualitative uncertainty of about 20 percent (moderate). The rigorous analysis conducted in this study provided spatial distribution for the numerical model that was not available previously, but the amount of recharge is similar to the $85,000 \mathrm{acre}-\mathrm{ft} / \mathrm{yr}$ estimated by Bjorklund and McGreevy (1974, p. 17) on the basis of specific yield and water-level fluctuations.

Although tailwater is not part of recharge from irrigation, the accounting and routing of tailwater is important in estimating groundwater discharge to rivers and other discharge areas. In the discharge calculations presented in the following sections, tailwater is considered an inflow to the river or discharge area. Tailwater from each irrigation area was routed on the land surface to rivers or groundwater discharge areas (table A1-5) using the National Elevation Dataset (U.S. Geological Survey EROS Data Center, 1999). 


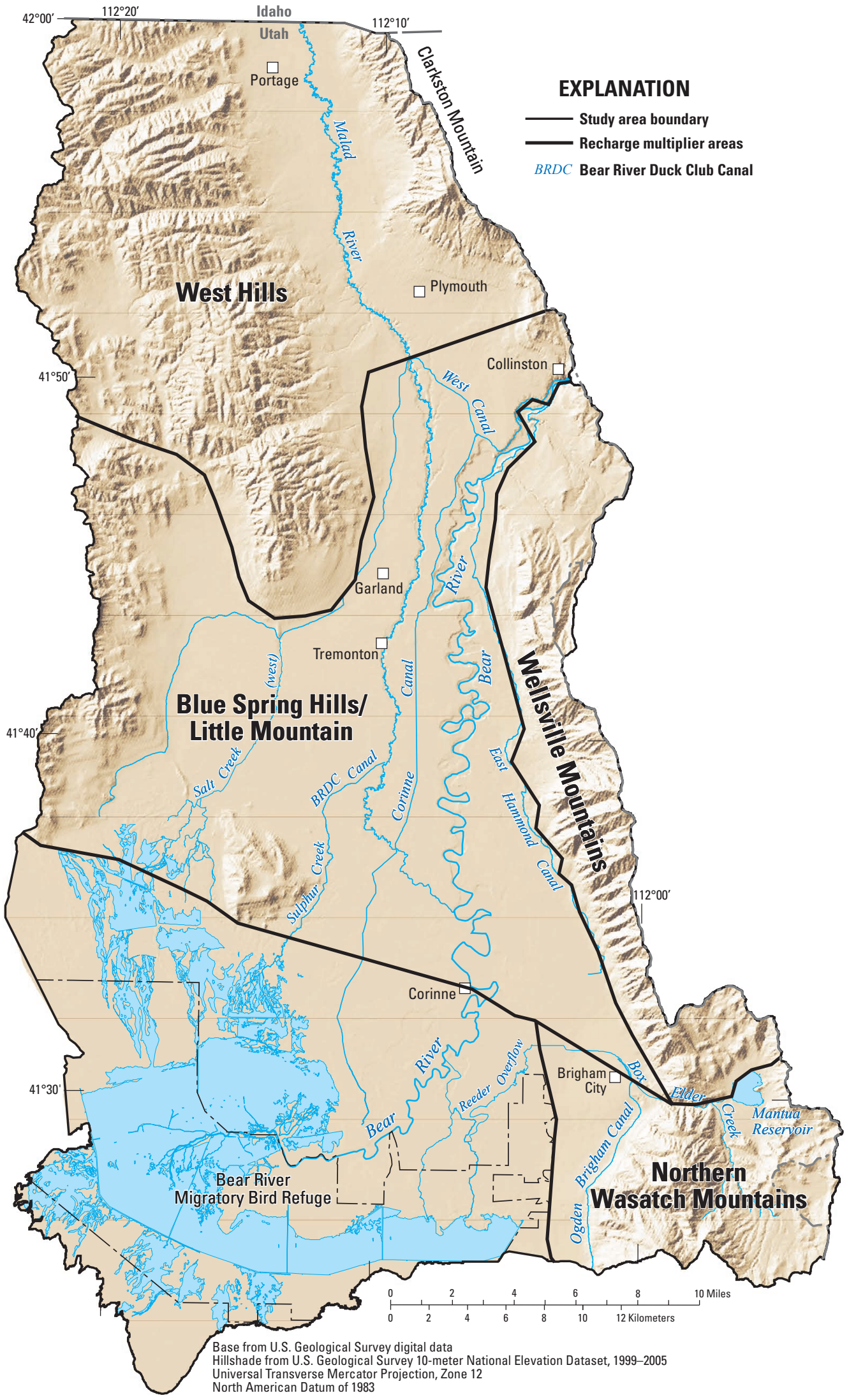

Figure 11. Basin Characterization Model multiplier areas, Malad-Lower Bear River study area. 


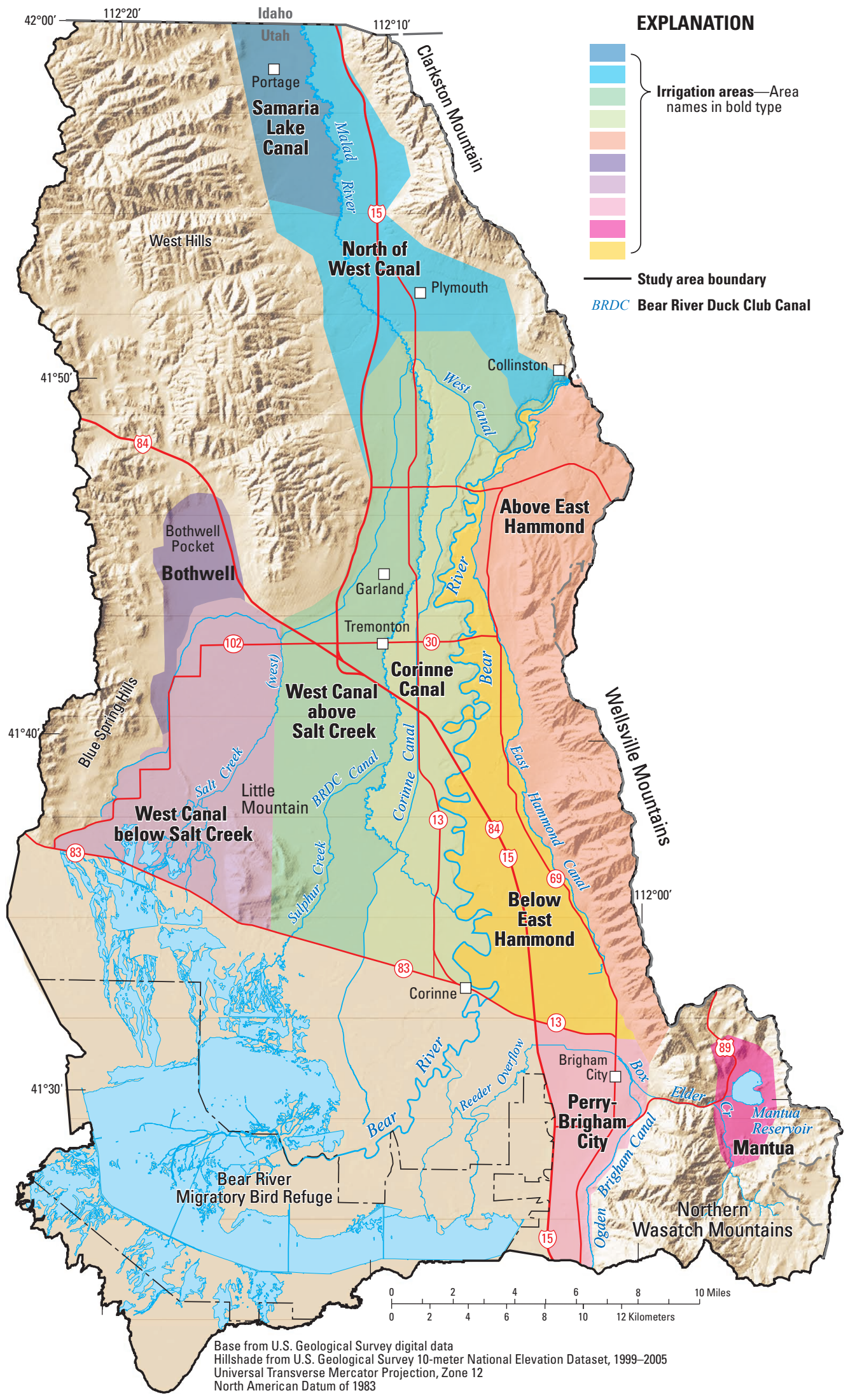

Figure 12. Irrigation areas, Malad-Lower Bear River study area. 
Table 3. Groundwater recharge from irrigation, Malad-Lower Bear River study area.

[Units in acre-feet per year. - , unknown but considered negligible]

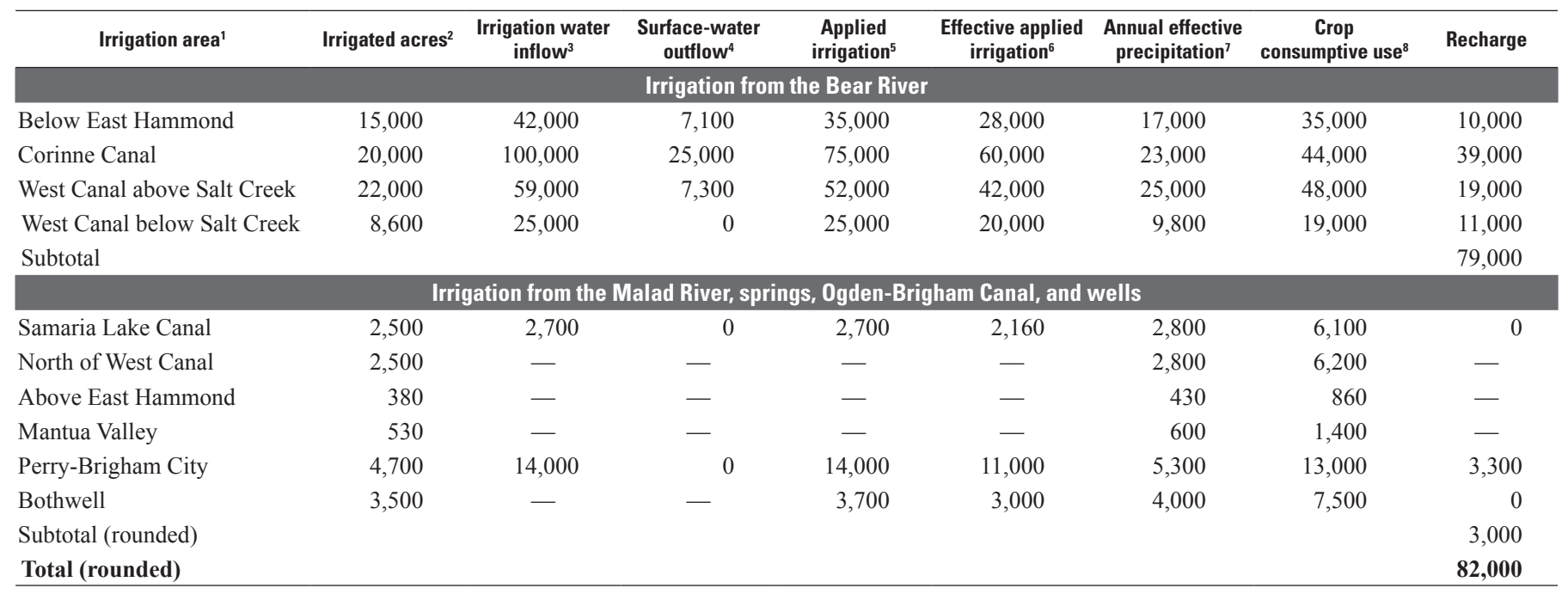

${ }^{1}$ Irrigation areas are shown on figure 12.

${ }^{2}$ Irrigated acres are detailed in table A1-2.

${ }^{3}$ Irrigation water inflow is listed in table 4.

${ }^{4}$ Surface-water outflow is in canals that convey water south and underneath State Highway 83 (table A1-4).

${ }^{5}$ Applied irrigation is Irrigation water inflow minus Surface-water outflow; Applied irrigation in the North of West Canal, Above East Hammond and Mantua Valley irrigation areas is unknown; Applied irrigation in the Bothwell irrigation area from unpublished U.S. Geological Survey records of groundwater pumping.

${ }^{6}$ Effective applied irrigation is estimated to be 80 percent of Applied irrigation; the remaining 20 percent is tailwater that flows to a down gradient groundwater discharge area or river reach.

${ }^{7}$ Annual effective precipitation is 80 percent of total precipitation, the remaining 20 percent is lost to sublimation and evaporation.

${ }^{8}$ Crop consumptive use is detailed in table A1-3.

Table 4. Average annual diversion from major canals to irrigation areas, Malad-Lower Bear River study area.

[Units in acre-feet per year]

\begin{tabular}{lcc}
\hline \multicolumn{1}{c}{ Canal } & $\begin{array}{c}\text { Annual diversion of water for } \\
\text { irrigation }\end{array}$ & Irrigation area $^{1}$ \\
\hline East Hammond Canal $^{2}$ & 42,000 & Below East Hammond \\
West Canal $^{3}$ & 201,000 & Corinne Canal $^{4}$ \\
& 100,000 & West Canal above Salt Creek $^{5}$ \\
& 59,000 & West Canal below Salt Creek $^{6}$ \\
Samaria Lake Canal $^{7}$ & 25,000 & Samaria Lake Canal \\
Ogden-Brigham Canal $^{8}$ & 2,700 & Perry-Brigham City \\
Total (rounded) & 14,000 & \\
\hline
\end{tabular}

${ }^{1}$ Irrigation areas are shown on figure 12.

${ }^{2}$ Annual diversion of water for irrigation from East Hammond Canal is based on U.S. Geological Survey gaging station 10117000 (HAMMOND (EAST SIDE) CANAL NEAR COLLINSTON, UT) 1961-2006, and State of Utah Division of Water Rights gaging station 1862 (2006-2013).

${ }^{3}$ Annual diversion of water for irrigation from West Canal is based on U.S. Geological Survey gaging station 10117500 (WEST CANAL NEAR COLLINSTON, UT) 1961-2006, and Utah Division of Water Rights gaging station 1863 (2006-2013).

${ }^{4}$ Annual diversion to Corinne Canal from West Canal is approximately 50 percent of the total West Canal diversion, based on miscellaneous current meter measurements (Darin McFarland, oral commun., March 2014).

${ }^{5}$ Calculated as difference between 50 percent of West Canal diversion (100,000 acre-feet per year) and average gaged flow at U.S Geological Survey gaging station 1017510 (WEST CANAL ABV SALT CREEK DIV NR TREMONTON UT) $1979-1986$.

${ }^{6}$ Average discharge from U.S. Geological Survey station 1017530 ( WEST CANAL BLW SALT CREEK DIV NR TREMONTON, UT) 1979-1986; Average spill from West Canal to Salt Creek between U.S. Geological Survey gaging stations 1017510 and 1017530 is 18,000 acre-feet per year.

${ }^{7}$ Average of single discharge measurements made by U.S. Geological Survey in 1967, 1968, 1970, and 2012.

${ }^{8}$ Compiled from Ogden-Brigham Canal records reported in Bjorklund and McGreevy, 1974, plus 90 percent of the estimated flow in Box Elder Creek at the point where water is diverted. Box Elder Creek flow is estimated from U.S. Geological Survey gaging station 10126400 (BOX ELDER CR AT MANTUA UTAH) 1961-1963, plus Mantua Valley spring discharge (Bjorklund and McGreevy, 1974) minus Brigham City Corporation diversions (oral commun., 2014). 


\section{Discharge}

The majority of groundwater discharge in the study area occurs to the Bear River and to springs in the study area (table 1). Additional groundwater discharge occurs to the Malad River, as areas of diffuse seepage, as direct evapotranspiration from the water table, and to wells.

\section{Malad and Bear Rivers}

All reaches of the Malad and Bear Rivers within the study area have net gains in streamflow (table 5). The difference in long-term streamflow records between consecutive gaging stations provides a robust and integrated measure of groundwater discharge directly to the rivers, discharge of field drains to the rivers, spring discharge to the rivers, tributary inflow, and irrigation tailwater flow to the rivers. Estimates of spring discharge to the rivers, tributary inflow, and irrigation tailwater flow in each reach is subtracted from the difference in the gaged streamflow to determine the amount of groundwater discharge directly to the rivers or to field drains that enter the rivers. Uncertainty in the estimated groundwater discharge is caused by possible error in streamflow measurements and by estimations of surface-water inflows (springs, tributaries, and tailwater). Consumption of stream water by riparian vegetation and direct pumping of water from the river are estimated to be small relative to the other factors influencing streamflow differences between gaging stations and are not considered in this analysis.

Average annual groundwater discharge to the Bear River is estimated for the 39-mi reach between streamflow gages near Collinston and Corinne, Utah (fig. 1). Discharge to the Malad River is partitioned into two reaches between streamflow gages and an additional reach downstream from the gages. Because there are no paired gaging stations on the Malad River between the Bear River Duck Club Canal diversion and the Bear River, individual streamflow measurements are used to estimate groundwater discharge in this reach. Annual inflow to the rivers from springs and tributaries was estimated from discrete measurements of the springs and tributaries (table A2-2). Synoptic seepage assessments confirm the discharge estimated from the streamflow gage data, and are used to distribute the groundwater discharge to shorter reaches of the rivers for use in the numerical groundwater flow model.

Groundwater discharge to rivers and field drains that enter rivers is estimated to be 95,000 acre-ft/yr (tables 1 and 5). Because long-term surface-water data from successive downstream gages represent a robust integrated signal of groundwater discharge to the rivers, the amount of discharge to rivers has an assigned qualitative uncertainty of low to moderate (about 10 percent for the Malad River and about 20 percent for the Bear River). Discharge to the Bear River has a higher uncertainty because of unknowns associated with discharge of springs and tributaries to the river.

Table 5. Groundwater discharge to the Bear and Malad Rivers, Malad-Lower Bear River study area.

[Units in acre-feet per year. —, unknown]

\begin{tabular}{|c|c|c|c|c|c|c|}
\hline River reach ${ }^{1}$ & $\begin{array}{l}\text { Surface-water } \\
\text { inflow }\end{array}$ & $\begin{array}{c}\text { Spring } \\
\text { discharge and } \\
\text { tributary stream } \\
\text { inflow }\end{array}$ & $\begin{array}{l}\text { Tailwater from } \\
\text { irrigation areas }\end{array}$ & $\begin{array}{l}\text { Surface-water } \\
\quad \text { outflow }\end{array}$ & $\begin{array}{l}\text { River gain based } \\
\text { on seepage } \\
\text { assessments }\end{array}$ & $\begin{array}{l}\text { Groundwater dis } \\
\text { charge including } \\
\text { field drains }\end{array}$ \\
\hline \multicolumn{7}{|c|}{ Bear River } \\
\hline Total & & & & & & 74,000 \\
\hline \multicolumn{7}{|c|}{ Malad River } \\
\hline $\begin{array}{l}\text { Malad River from Bear River Duck Club Diversion to Bear } \\
\text { River }^{7}\end{array}$ & - & - & 6,000 & - & ${ }^{6} 10,000$ & 4,000 \\
\hline Total (rounded) & & & & & & 21,000 \\
\hline
\end{tabular}

${ }^{1}$ River reach shown on figure 1.

${ }^{2}$ Tailwater from irrigation areas is detailed in table A1-5.

${ }^{3}$ Surface-water inflow is the annual mean for 1964-2010 from U.S. Geological Survey gaging station 10118000 (BEAR RIVER NEAR COLLINSTON, UT) 1964-1995 and State of Utah Division of Water Rights gaging station 1901, 1996-2010; Spring discharge and tributary stream inflow includes an estimated mean of 32,000 acre-feet per year for 1964-2010 for the Malad River below the Bear River Duck Club Diversion (see footnote 7 for explanation); 10,000 acre-feet per year river gain based on seepage assessments (see this table, Malad River from Bear River Duck Club Diversion; 12,000 acre-feet per year as tributary inflow from Salt Creek (east) (see table A2-1); and 3,600 acre-feet per year from springs (see table 9, Springs that discharge to Bear River); Surface-water outflow calculated from U.S. Geological Survey gaging station 10126000 (BEAR RIVER NEAR CORINNE, UT) 1964-2010.

${ }^{4}$ Surface-water inflow from U.S. Geological Survey gaging station 10125500 (MALAD RIVER AT WOODRUFF, ID) 1965-1980: Spring discharge and tributary stream inflow listed in table A2-2 (Malad River, September 13-14, 2012, (B-14-3)10cac-S1, 10cdb-S1, and 27dcb-S1; (B-13-3)4ddd-S1, and 9aac-S1, and 23aca; Surface-water outflow calculated from U.S. Geological Survey gaging station 10125600 (MALAD RIVER NEAR PLYMOUTH, UTAH) $1965-1980$.

${ }^{5}$ Surface-water inflow from U.S. Geological Survey gaging station 10125600 (MALAD RIVER NEAR PLYMOUTH, UT) 1965-1973: Spring discharge and tributary stream inflow listed in table A2-2 (Malad River, August 12-13, 1971, September 13-14, 2012, and Feburary 20, 2013 (B-12-3)12dab; Surface-water outflow calculated from U.S. Geological Survey gaging stations 10125700 (BEAR RIVER DUCK CLUB CAN NR BEAR RIVER CITY, UT) and 10125800 (MALAD R BL BRN DUCK CL CAN NR BEAR RIVER CITY, UT) $1965-1973$.

${ }^{6}$ River gain based on seepage assessments is average amount measured in August 1971, April 24, 2013, and November 6, 2013.

${ }^{7}$ The 1964-2010 annual mean streamflow in the Malad River below the Bear River Duck Club Diversion was estimated by comparing streamflow from U.S. Geological Survey gaging station 10125800 (MALAD R BL BRN DUCK CL CAN NR BEAR RIVER CITY, UT) for 1965-1973, and streamflow from U.S. Geological Survey gaging station 10126000 (BEAR RIVER NEAR CORINNE, UT) for the same time period. Comparison shows that streamflow in the Malad River below the Bear River Duck Club Diversion was 2.67 percent of streamflow in the Bear River near Corinne. The percentage for 1965-73 was applied to the 1964-2010 annual mean for the Bear River near Corinne to estimate the 1964-73 annual mean for the Malad River below the Bear River Duck Club Diversion. 


\section{Stable Isotopes}

The stable isotopes of water, hydrogen-2 or deuterium $\left({ }^{2} \mathrm{H}\right)$ and oxygen-18 $\left({ }^{18} \mathrm{O}\right)$, were used to evaluate sources and movement of groundwater that discharge to the Malad River. Isotopic composition is reported as the ratio of the rare to common isotope $\left({ }^{2} \mathrm{H} /{ }^{1} \mathrm{H}\right.$ and $\left.{ }^{18} \mathrm{O} /{ }^{16} \mathrm{O}\right)$. The ratio is reported relative to a standard (Vienna Standard Mean Ocean Water [VSMOW]) in units of parts per thousand (permil) as $\delta^{18} \mathrm{O}$ and $\delta^{2} \mathrm{H}$ values.

The sources of groundwater inflow to the Malad River are recharge from precipitation and recharge from irrigation. Samples collected from five springs and a well, all upgradient of irrigation canals (fig. 13A), are assumed to represent the isotopic composition of groundwater recharged from precipitation. A sample collected from West Canal is assumed to represent the isotopic composition of groundwater recharged from irrigation. Isotopic ratios of groundwater recharged from precipitation are significantly lighter (more negative) than surface water applied for irrigation (fig. 13B). The water in West Canal is enriched due to evaporation at Cutler Dam and further enriched when applied for irrigation. The isotopic ratios of the two sources of groundwater (fig. 13B, table A1-10) were used to establish a mixing line that shows theoretical isotopic ratios of waters that are a combination of groundwater recharged from precipitation and groundwater recharged from irrigation.

Malad River water was collected from a reach adjacent to irrigated areas. Isotopic ratios of water collected in winter, when there is no irrigation, are similar to groundwater recharged from precipitation. This indicates that the source of groundwater inflow to the Malad River during the winter is recharge from precipitation. Samples collected during the summer have isotopic values that are enriched (less negative) relative to the winter values. This indicates that the source of inflow to the river is a mixture of groundwater recharged from precipitation and groundwater recharged from irrigation. The small shift of the summer values to the right of the theoretical mixing line may be due to additional evaporation of the canal water when applied to the irrigated areas. Streamflow gaging records and seepage assessments (table A2-1) quantified a nearly three-fold increase in net inflow to the Malad River during the summer.

\section{Discharge Areas}

Areal discharge of groundwater occurs in the valley areas where the water table is near or intersects land surface. Seven groundwater discharge areas (fig. 14) were delineated on the basis of topography and surface drainage using the National Elevation Dataset (U.S. Geological Survey EROS Data Center, 1999) and land cover. Land cover is determined from the National Land Cover Dataset (Homer and others, 2015, natural vegetation and playa areas) and satellite imagery from the National Agriculture Imagery Program (2011). Areal groundwater discharge includes both diffuse seepage to land surface and ETg. Diffuse seepage is quantified on the basis of measured surface-water inflows and outflows. ETg is determined from the occurrence and consumptive use of non-cultivated vegetation. Although quantified independently, diffuse seepage and ETg processes are interrelated. During summer, increased ETg results in less diffuse seepage because groundwater is diverted to plant roots rather than discharging at land surface. During winter, the effect is opposite as ETg is decreased and diffuse seepage increases. The magnitude of interaction between the two processes is not fully described by available data, and is a source of uncertainty in the areal discharge estimates.

\section{Diffuse Seepage}

Groundwater discharge as diffuse seepage was estimated for five of the groundwater discharge areas shown on figure 14 by using a water-balance approach (table 6). Inflow consists of surface water from diversions, tailwater from adjacent irrigation areas, and measured spring discharge within the area. Outflow was determined from gaged, estimated, and instantaneous measurements of all identifiable surface water leaving the groundwater discharge area. Diffuse seepage is quantified as outflow minus inflow. The separate components of inflow and outflow are listed in table A1-6.

Diffuse seepage is negligible in the Upper Malad discharge area as shown by lack of gain in the Malad River through the area (appendix 2). For Salt Creek (east), surface-water outflow is based on three measurements of streamflow at and near the confluence with the Bear River. Surface-water inflow and outflow from the Sulphur Creek groundwater discharge area is based on 1972-73 data from USGS gaging stations at the Bear River Duck Club Canal diversion from the Malad River and Sulphur Creek where it flows under Highway 83.

Surface-water outflow from Black Slough, Corinne, and West of Little Mountain groundwater discharge areas was determined from instantaneous measurements of surfacewater flows at Highway 83 during 1972-1986 (table 7). Gaged streamflows for the Bear River at Corinne, Black Slough, and Sulphur Creek, and calculated flows in Hammond West 


\section{EXPLANATION}

$7 \triangle$ Groundwater recharge from precipitation

$13 \triangle$ Groundwater recharge from irrigation $3 \bigcirc$ Malad River (summer sampling sites)

$6 \bigcirc$ Malad River (summer and winter sampling sites)

Number is site identification (see table A1-10)
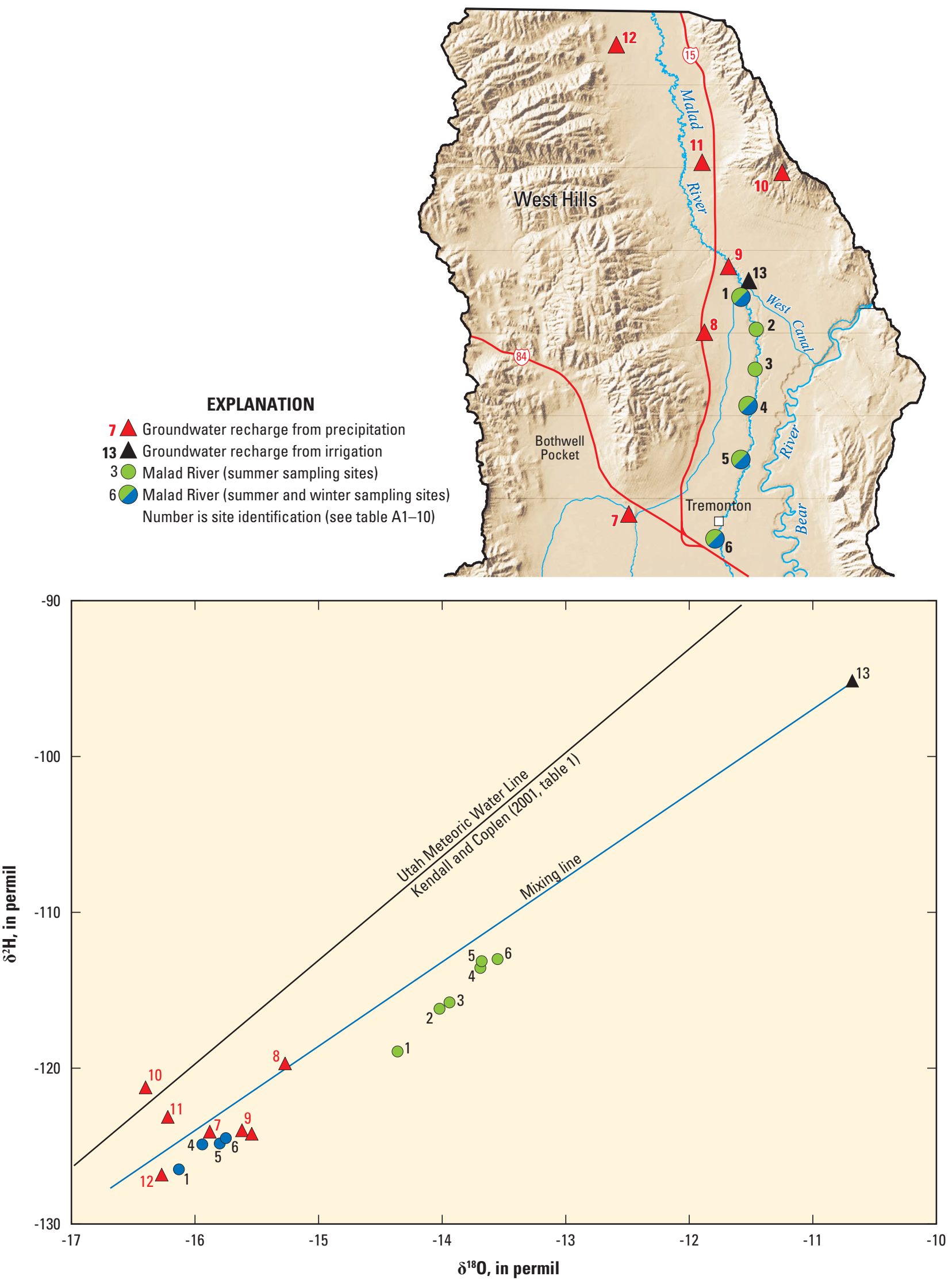

Figure 13. Locations $A$, and plot of $\delta^{18} 0$ versus $\delta^{2} H B$, for samples collected from the West Canal, Malad River, and surrounding areas, Malad-Lower Bear River study area. 


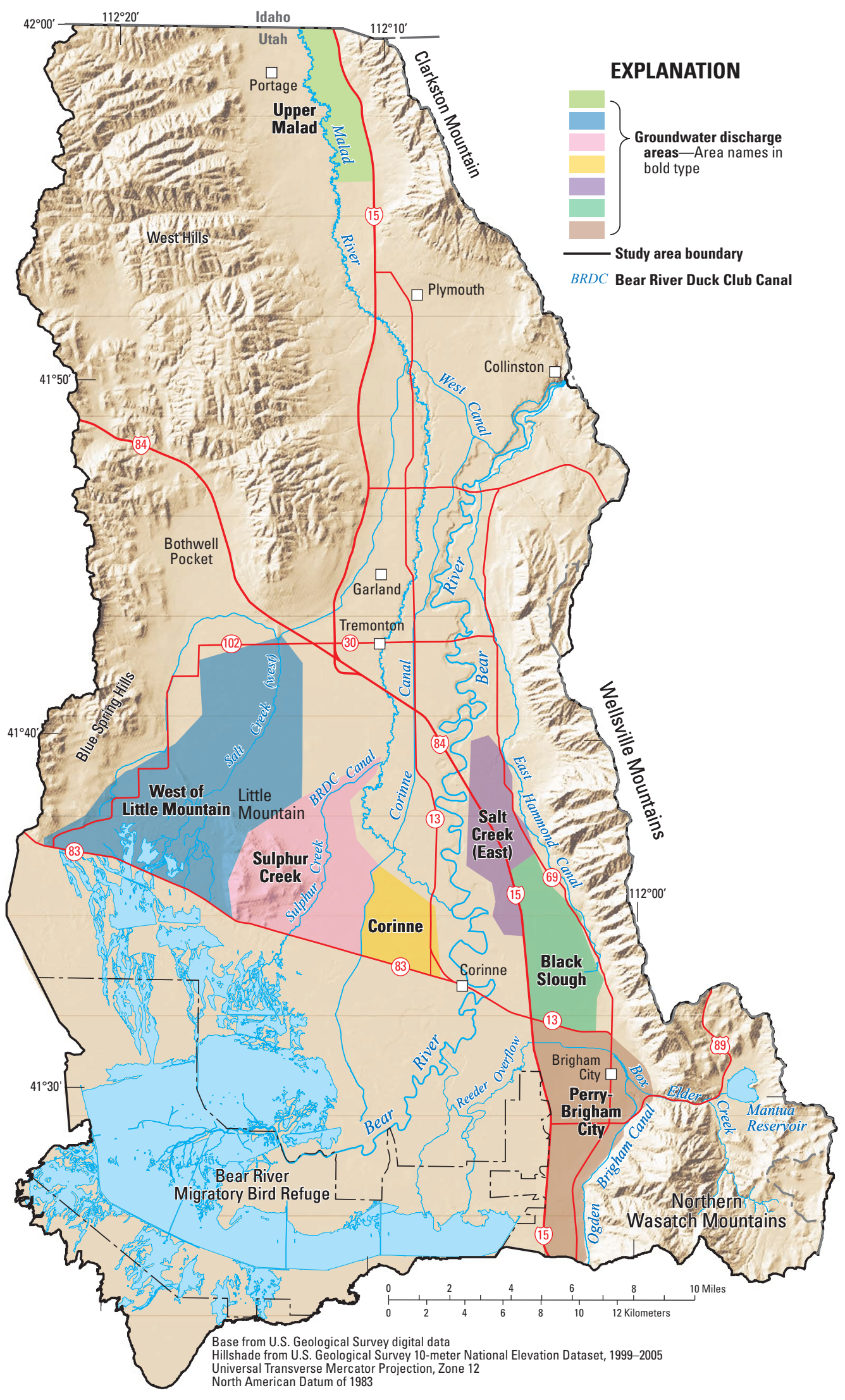

Figure 14. Groundwater discharge areas, Malad-Lower Bear River study area. 
Bench, Corinne, and Central irrigation canals are subtracted from total flow at Highway 83 because they are included in separate calculations. Instantaneous measurements of flow in the canals (table A1-4) are converted to annual volumes based on the assumption that canals only convey water during the irrigation season (approximately 170 days a year). Instantaneous measurements of flow at the culverts and bridges (fig. 15, table A1-7) are converted to annual volumes based on the assumption that those flows are perennial. Because few measurements of flow were made at the culverts and bridges, and because most of those were made in the mid-1980s, the flows may not be representative of long-term conditions. To account for this, the flow in Bear River at Corinne, Black Slough, Sulphur Creek, Hammond West Bench Canal, Corinne Canal, and Central Canal were subtracted from the flow at USGS gaging station 10127110 (B R BASIN OUTFLOW AC ST HWY 83 NR CORINNE, UT) for the years 1972-86; the resulting difference is $57,000 \mathrm{acre}-\mathrm{ft} / \mathrm{yr}$. The instantaneous flow measurements at canals and bridges are used to partition the average 57,000 acre-ft/yr to individual groundwater discharge areas (table A1-7).

Table 6. Groundwater discharge as diffuse seepage, Malad-Lower Bear River study area.

[Units in acre-feet per year]

\begin{tabular}{|c|c|c|c|c|c|}
\hline \multirow[b]{2}{*}{$\begin{array}{l}\text { Groundwater discharge areas for which } \\
\text { diffuse seepage was estimated' }\end{array}$} & \multicolumn{3}{|c|}{ Inflow } & \multirow[b]{2}{*}{$\begin{array}{l}\text { Surface-water } \\
\text { outflow }^{2}\end{array}$} & \multirow[b]{2}{*}{$\begin{array}{c}\text { Groundwater } \\
\text { discharge as } \\
\text { diffuse seepage }\end{array}$} \\
\hline & Surface water ${ }^{2}$ & $\begin{array}{l}\text { Irrigation } \\
\text { tailwater }^{3}\end{array}$ & $\begin{array}{c}\text { Spring } \\
\text { discharge } \\
\text { within area }^{4}\end{array}$ & & \\
\hline Salt Creek (east) & 0 & 1,400 & 9,800 & 12,000 & 800 \\
\hline Black Slough & 0 & 1,400 & 5,700 & 16,000 & 8,900 \\
\hline Sulphur Creek & 37,000 & 3,000 & 0 & 50,000 & 10,000 \\
\hline Corinne & 0 & 1,500 & 0 & 2,200 & 700 \\
\hline West of Little Mountain & 18,000 & 7,000 & 24,000 & 51,000 & 2,000 \\
\hline Total (rounded) & & & & & 22,000 \\
\hline
\end{tabular}

${ }^{1}$ Groundwater discharge areas are shown on figure 14.

${ }^{2}$ Surface-water inflow and Surface-water outflow are detailed in table A1-6; Surface-water outflow for Corinne groundwater discharge area is detailed in table A1-4.

${ }^{3}$ Irrigation tailwater is detailed in table A1-5.

${ }^{4}$ Spring discharge within study area is detailed in table 9.

${ }^{5}$ Groundwater as diffuse discharge is calculated as Surface-water outflow minus Surface-water inflow minus Irrigation tailwater minus Spring discharge within area.

Table 7. Average annual surface-water flow at State Highway 83, Malad-Lower Bear River study area.

[Units in acre-feet per year]

\begin{tabular}{|c|c|}
\hline Name & $\begin{array}{l}\text { Annual average surface-water } \\
\text { flow across State Highway } 83\end{array}$ \\
\hline Streamflow in Bear River near Corinne ${ }^{1}$ & $1,744,000$ \\
\hline Streamflow in Black Slough near Brigham City ${ }^{2}$ & 40,900 \\
\hline Streamflow in Sulphur Creek near Corinne ${ }^{3}$ & 45,600 \\
\hline Hammond West Bench Canal ${ }^{4}$ & 7,100 \\
\hline Corinne Canal ${ }^{4}$ & 25,000 \\
\hline Central Canal ${ }^{4}$ & 7,400 \\
\hline Subtotal & $1,870,000$ \\
\hline Surface-water outflow at State Highway 83 from Black Slough groundwater discharge area ${ }^{5}$ & 2,800 \\
\hline Surface-water outflow at State Highway 83 from Corinne groundwater discharge area $^{5}$ & 2,200 \\
\hline Surface-water outflow at State Highway 83 from West of Little Mountain groundwater discharge area ${ }^{5}$ & 51,000 \\
\hline Subtotal (surface-water outflow across State Highway 83 in 27 culverts/bridges) & 56,000 \\
\hline Total annual average surface-water flow across State Highway $83^{6}$ & $1,926,000$ \\
\hline
\end{tabular}

${ }^{1}$ U.S. Geological Survey gaging station 10126000 (BEAR RIVER NEAR CORINNE, UT) 1972-1986.

${ }^{2}$ U.S. Geological Survey gaging station 10127100 (BLACK SLOUGH NEAR BRIGHAM CITY, UTAH) 1972-1986, which includes Box Elder Creek streamflow.

${ }^{3}$ U.S. Geological Survey gaging station 10126180 (SULPHUR CREEK NR. CORINNE, UT) 1972-1986.

${ }^{4}$ Canal flows are determined from instantaneous flow measurements made from 1972 through 1986. Annual flow volumes are calculated from instantaneous measurements assuming that canals convey water only during the irrigation season. The average length of the irrigation season is estimated to be 170 days. Canals were assumed to be dry for 195 days.

${ }^{5}$ Estimates of surface-water outflow from groundwater discharge areas were made by assigning specific culverts/bridges to specific groundwater discharge areas. Because surface water in culverts/bridges originates from multiple sources (springs, diffuse seepage, and canals), annual volumes are based on the assumption that flow is perennial (365 days per year). Annual flow volumes calculated from instantaneous measurements are scaled to total the residual (57,000 acre-feet per year) between total flow across State Highway 83 and the sum of gaged streamflow and estimated canal flows. An estimated 1,000 acre-feet per year of additional surface water flows across State Highway 83 west of the groundwater budget accounting area. Details are listed in table A1-7.

${ }^{6}$ U.S. Geological Survey gaging station 10127110 (B R BASIN OUTFLOW AC ST HWY 83 NR CORINNE, UT) 1972-1986. 


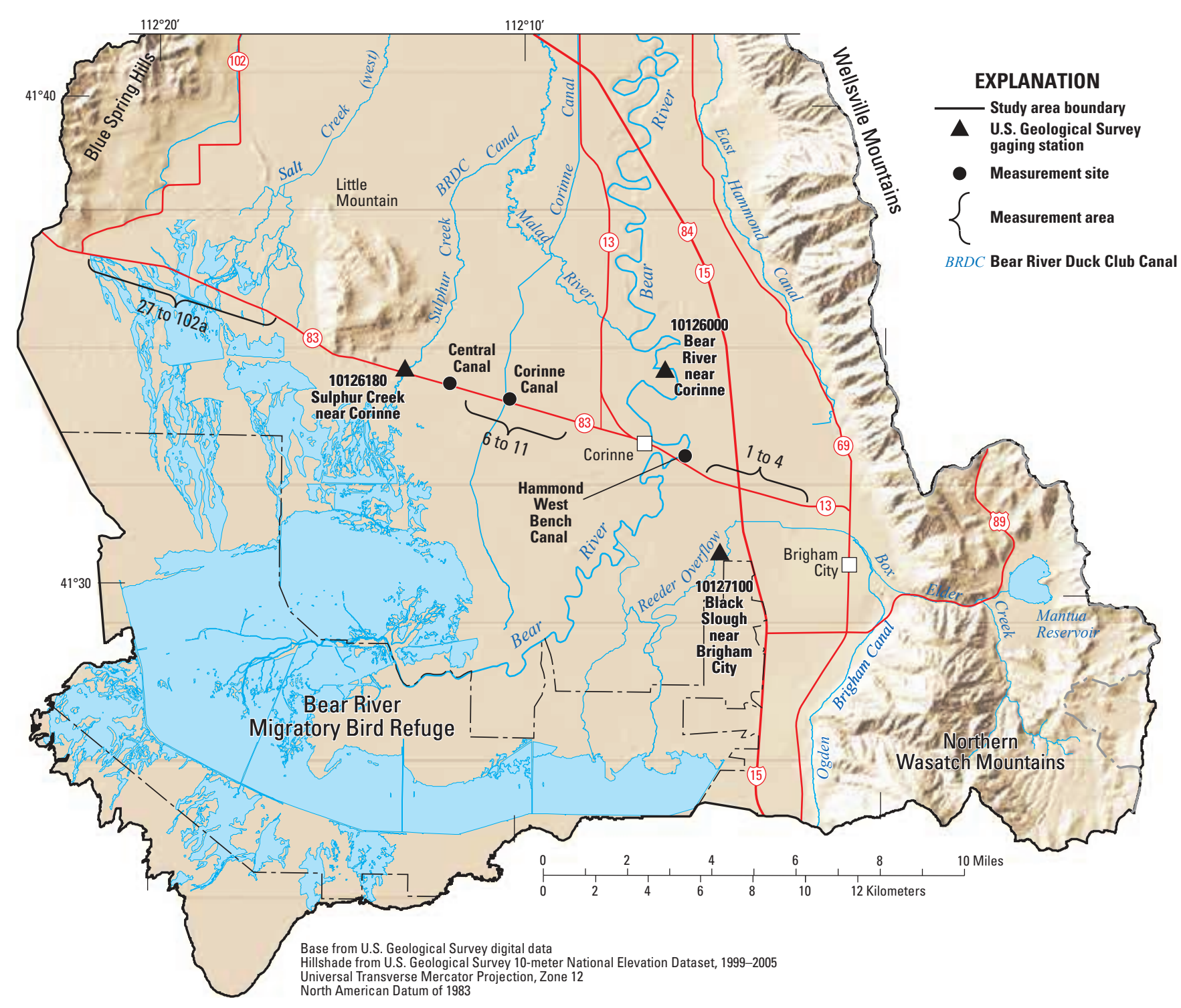

Names correspond to location in table 7

Numbering corresponds to measurement location number in table A1-7

Measurement location numbers 1 to 4 indicate where surface water is conveyed from the Black Slough groundwater discharge area

Measurement location numbers 6 to 11 indicate where surface water is conveyed from the Corinne groundwater discharge area

Measurement location numbers 27 to 102a indicate where surface water is conveyed from the West of Little Mountain groundwater discharge area

Figure 15. Measurement locations used to estimate 1972-1986 average annual volume of surface-water flow at State Highway 83, Malad-Lower Bear River study area.

Total estimated discharge to the diffuse seepage areas is $22,000 \mathrm{acre}-\mathrm{ft} / \mathrm{yr}$ (tables 1 and 6). Because diffuse seepage is calculated as the residual of numerous measurements and estimates, the estimate of discharge is considered to have a qualitative uncertainty of at least 30 percent (high). In addition, because the emphasis of this project was on the Malad River, detailed field investigations of surface-water outflow from the Perry-Brigham City area were not done, and a water budget for the area was not calculated. Diffuse seepage may occur in the area but is not included in the groundwater budget.

\section{Evapotranspiration}

Evapotranspiration of groundwater (ETg) within the seven groundwater discharge areas (fig. 14) is based on total acreage of emergent herbaceous wetlands, hay/pasture, woody wetlands, barren land, and open water (table A1-8; Homer and others, 2015). Consumptive use for each land cover is assigned a value from Hill and others (2011, appendix J) and Masbruch and others (2011). Precipitation rate is the National Climatic Data Center 30-year average annual precipitation for Tremonton, UT (17.03 inches, Western Regional Climate Center, 2012); all precipitation is considered to be available 
for use by natural vegetation. The ETg is calculated as the difference between consumptive use and precipitation; the average annual total is 26,000 acre- $\mathrm{ft}$ (table 8 ). The estimate is considered to have moderate uncertainty of about 20 percent because of the application of consumptive use estimates from other areas, changing plant type, and application of the same precipitation at all locations.

\section{Springs}

Springs in the study area are used for municipal supply, to provide water to rivers and wetland areas, and for recreation at resorts associated with Crystal Hot and Cold Springs and Udy Springs (fig. 16). Discharge to springs is estimated on the basis of measurements made by Bjorklund and McGreevy (1974), municipal records, and measured discharges in 2012-13 (table A1-9). For the budget analysis in this report, springs are grouped into general areas that relate to surface-water and groundwater discharge areas (table 9). Numerous carbonaterock springs exist in Mantua Valley that provide municipal water for Brigham City, water for a State of Utah fish hatchery, and streamflow to Box Elder Creek below the gage. Most of the springs are east of the Bear River and generally have lower dissolved-solids concentrations than springs near or west of the Malad River (Bjorklund and McGreevy, 1973, table 5); many are developed for municipal water supply. The source of water for springs east of the Bear River is recharge on the Northern Wasatch and Wellsville Mountains. Although most springs are east of the Bear River, several large-discharge springs are located west of the Malad River, including Udy Springs, Salt Springs (west), and springs around Jesse's Knoll (fig. 16). These springs discharge slightly saline to briny water (Bjorklund and McGreevy, 1974, p. 23). The likely source of water for these springs is the low mountains west of the valley, and possibly interbasin flow from adjacent areas.
Total discharge to springs is about 74,000 acre-ft/yr with a qualitative uncertainty of at least 30 percent (high). Most springs have been measured or estimated only a few times, making extrapolation to average annual flows uncertain. Adding to the uncertainty, municipal records are unclear as to whether total discharge or only the amount used is reported.

\section{Well Withdrawals}

Groundwater withdrawals from wells are a small part of the groundwater budget (table 1, fig. 17). Groundwater pumping for municipal use represents the majority of well withdrawals and occurs throughout the study area. Some small wells supply water to private residences. Most industrial water use, except near Plymouth, is supplied by municipalities. Pumping augments springs, which are the largest source of municipal water. In general, municipal pumping has been increasing on the order of $100 \mathrm{acre}-\mathrm{ft} / \mathrm{yr}$ from the late $1970 \mathrm{~s}$ to the early 2010s (Utah Division of Water Rights database, accessed July 12, 2014, at http://www.waterrights.utah.gov). Irrigation well withdrawals are mainly in the Bothwell Pocket area. Additional pumping for irrigation occurs near the mountain front south of Brigham City. Irrigation withdrawals depend on climatic conditions and vary annually, but overall long-term pumping has remained relatively constant from 1976-2013. Irrigation withdrawals for the study area were obtained from Burden and others (2015). Because well discharge is either provided by the cities or estimated for each well by the USGS, the estimated annual well withdrawal of about 11,000 acre- $\mathrm{ft}$ (table 1) is assigned a qualitative uncertainty of about 10 percent (low).

Table 8. Groundwater discharge as evapotranspiration, Malad-Lower Bear River study area.

[See table A1-8 for additional information]

\begin{tabular}{|c|c|c|c|c|c|c|}
\hline Groundwater discharge area' & $\begin{array}{c}\text { Area size }^{2} \\
\text { (acres) }\end{array}$ & $\begin{array}{c}\text { Evapotranspiration } \\
\text { rate } \\
\text { (feet per year) }\end{array}$ & $\begin{array}{l}\text { Evapotranspiration } \\
\text { volume } \\
\text { (acre-feet per year) }\end{array}$ & $\begin{array}{c}\text { Precipitation } \\
\text { volume } \\
\text { (acre-feet per year) }\end{array}$ & $\begin{array}{c}\text { Effective } \\
\text { evapotranspiration } \\
\text { (acre-feet per year) }\end{array}$ & $\begin{array}{c}\text { Groundwater } \\
\text { discharge as } \\
\text { evapotranspiration } \\
\text { (acre-feet per year) }\end{array}$ \\
\hline Upper Malad & 1,800 & 2.8 & 5,000 & 2,600 & 2,400 & 2,400 \\
\hline Salt Creek (east) & 1,100 & 2.7 & 3,000 & 1,500 & 1,500 & 1,500 \\
\hline Black Slough & 3,800 & 2.1 & 7,900 & 3,800 & 4,100 & 4,100 \\
\hline Sulphur Creek and Corinne & 1,100 & 2.8 & 3,100 & 1,500 & 1,600 & 1,600 \\
\hline West of Little Mountain & 9,500 & 2.6 & 25,000 & 12,000 & 13,000 & 13,000 \\
\hline Perry-Brigham City & 1,700 & 2.8 & 4,700 & 2,400 & 2,300 & 2,300 \\
\hline Along rivers and isolated small areas ${ }^{3}$ & 3,300 & 2.9 & 9,700 & 4,700 & 5,000 & 1,500 \\
\hline Total (rounded) & & & & & & 26,000 \\
\hline
\end{tabular}

${ }^{1}$ Groundwater discharge areas are shown on figure 14.

${ }^{2}$ Area size from National Land Cover Data, 2011.

${ }^{3}$ Because of proximity to surface water, Effective evapotranspiration along rivers and isolated small areas represents discharge from both surface water and groundwater. Evapotranspiration supplied by surface water is estimated to be 3,500 acre-feet per year (1,000 acre-feet per year from open water within the river corridor and 2,500 acre-feet per year as subsurface loss to riparian vegetation). The remaining 1,500 acre-feet per year is considered Groundwater discharge as evapotranspiration. Evapotranspiration supplied by surface water is not accounted for in other budget categories. 


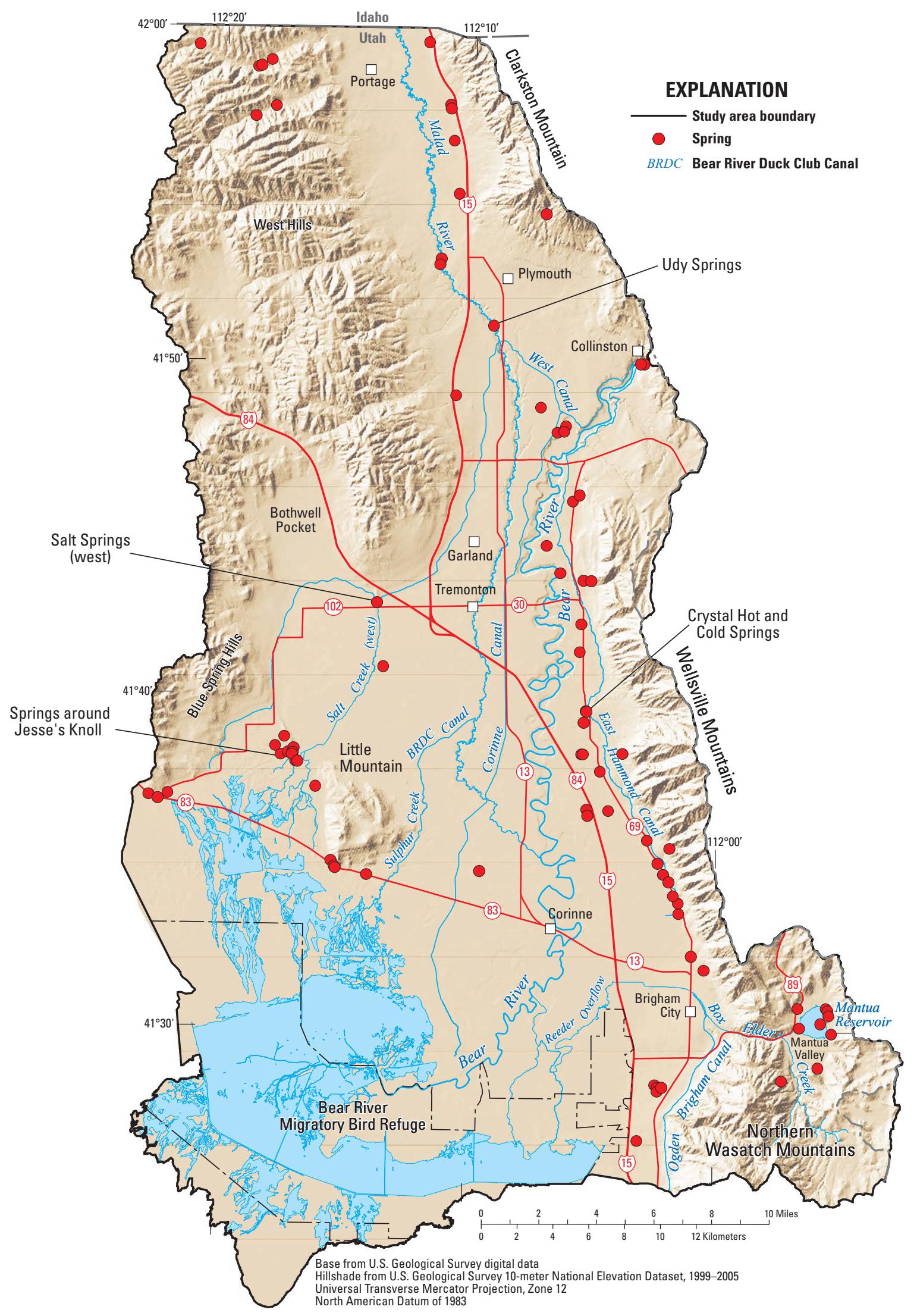

Figure 16. Location of selected springs, Malad-Lower Bear River study area. 
Table 9. Spring discharge for generalized areas, Malad-Lower Bear River study area.

[Units in acre-feet per year]

\begin{tabular}{|c|c|}
\hline Area & Spring discharge ${ }^{1}$ \\
\hline Mantua Valley & 21,000 \\
\hline Perry-Brigham City groundwater discharge area & 2,900 \\
\hline Salt Creek (east) groundwater discharge area & 9,800 \\
\hline Black Slough groundwater discharge area & 5,700 \\
\hline Springs and drains on eastern edge of valley, north of State Highway 83 and south of Collinston & 870 \\
\hline Springs that discharge to Bear River & 3,600 \\
\hline \multicolumn{2}{|l|}{ West of Little Mountain groundwater discharge area } \\
\hline Salt Creek Springs ${ }^{2}$ & 15,000 \\
\hline Springs west of Sulphur Creek and north of State Highway $83^{2}$ & 1,900 \\
\hline Jesse's Knoll area² & 6,500 \\
\hline Field drains between Malad River and Sulphur Creek & 160 \\
\hline Springs that discharge to Malad River & 5,600 \\
\hline Springs east of Malad River and north of Collinston & 300 \\
\hline Springs west of Malad River and north of Tremonton & 1,100 \\
\hline Total (rounded) & 74,000 \\
\hline
\end{tabular}

Spring discharge is detailed in table A1-9.

${ }^{2}$ Springs discharge within West of Little Mountain groundwater discharge area.

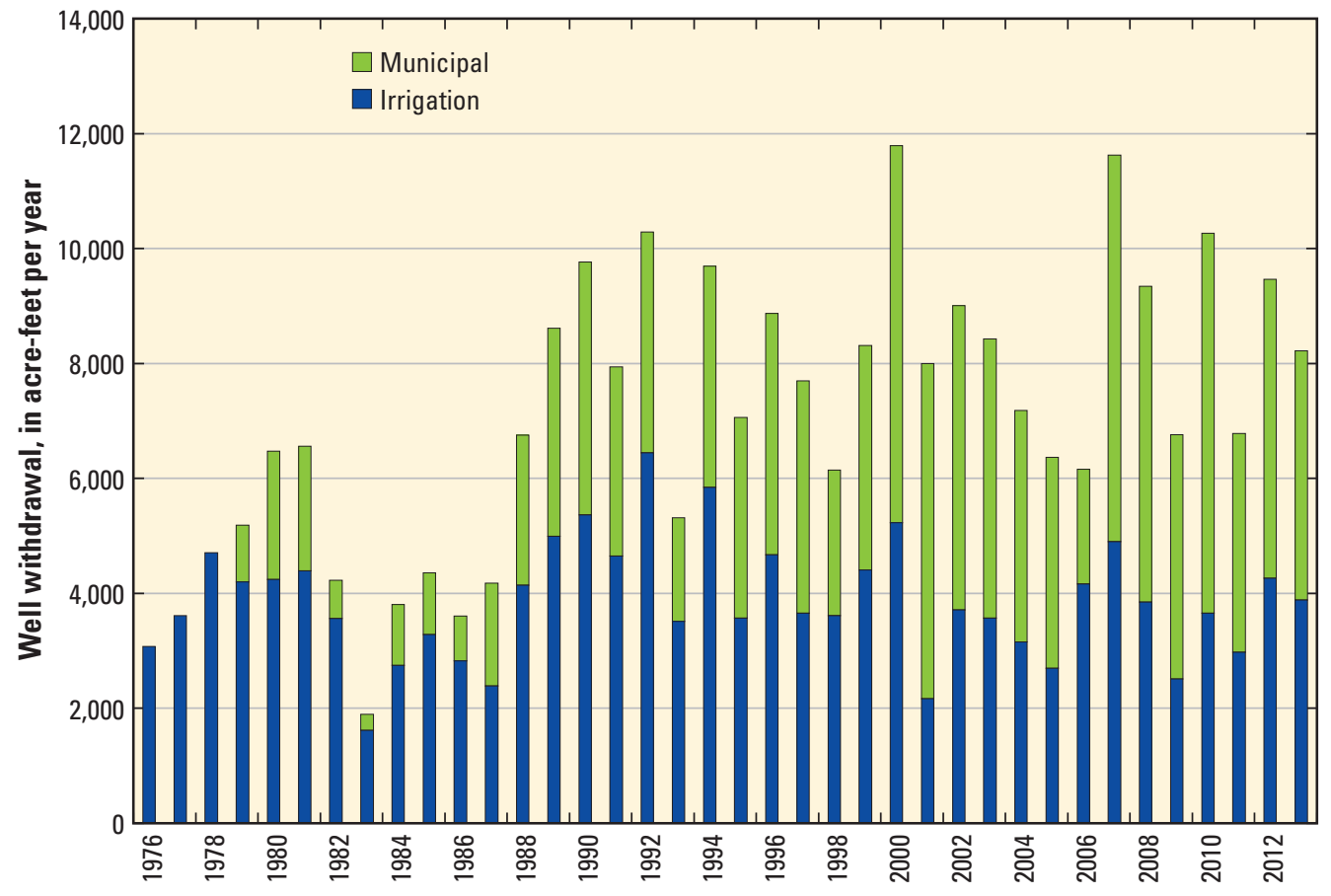

Figure 17. Annual municipal and irrigation well withdrawals, 1976-2013, Malad-Lower Bear River study area.

\section{Imbalance}

Under steady-state hydrologic conditions and no subsurface flow into or out of an area, groundwater discharge is equal to groundwater recharge. Imbalance in the estimated groundwater budget (table 1) results from system complexities that are not fully understood or correctly quantified. Although the budget imbalance appears large, if recharge were increased by 16 percent (or 26,000 acre-ft/yr of subsurface inflow occurs) and if discharge were reduced by 16 percent, the groundwater budget would balance with about $190,000 \mathrm{acre}-\mathrm{ft} / \mathrm{yr}$ of recharge or inflow and 190,000 acre-ft/yr of discharge. The greatest uncertainty is related to recharge estimates and the possibility of subsurface inflow to the study area. The discharge components of the budget are better understood and quantified. Discharge often occurs at discrete locations, where it can be described and quantified.

Adjustments that increase BCM estimates of recharge (see "Precipitation" section of this report) are for specific locations and address only a small portion of the budget imbalance (table 1). Even with adjustments, total recharge from precipitation is considered a minimum. In addition to the uncertainty of recharge estimates within the study area, it is likely that subsurface inflow to the study area occurs from the north and 
the surrounding mountains and valleys. At the regional scale, Heilweil and Brooks (2011, pl. 2) show that water levels in surrounding valleys are generally higher than in the study area and the likelihood of hydraulic connections across study area boundaries in the area is uncertain or high. At a more local scale, geologic structure, jointing, and faulting in the Wellsville Mountains indicate groundwater flow across the topographic divide is possible (Hurlow, 1999, p. 4).

\section{Previous Groundwater Budget}

The estimated total annual recharge of 315,000 acre-ft/yr in the previous groundwater budget (Bjorklund and McGreevy, 1974, p. 16) was determined by subtracting evaporation (not including ETg) and runoff from precipitation, diversions, and subsurface inflow to obtain the amount of water that would be available to recharge the groundwater system. Total discharge is balanced to match the estimated recharge (Bjorklund and McGreevy, 1974, p. 21). Budget components that could be separated out from the total budget are listed below. Comparison to budget values presented in this report (table 1) assumes that "recharge areas" referred to by Bjorklund and McGreevy (1974) loosely correspond to the budget area delineated in this report (north of Highway 83, and east of Interstate15 south of Brigham City).

The previous and current budgets differ most in recharge from precipitation and discharge as ETg. The previous estimate of ETg was determined by subtracting discharge to rivers, springs, and wells from total recharge (315,000 acre-ft/yr). The ETg in this report is determined from a detailed water balance for seven groundwater discharge areas (table 8), and is considered a more accurate estimate. Both the previous and current estimates of recharge from precipitation are problematic. The previous estimates from Bjorklund and McGreevy (1974, p. 16) may be high because of the following: (1) subsurface inflow should not be included as water that can be evapotranspired or as runoff from recharge areas, and (2) water diverted for irrigation is not 100 percent efficient. The previous quantification of subsurface inflow is highly uncertain because it is calculated as a difference between values that

\section{Budget components}

\begin{tabular}{lcc}
\hline \multicolumn{1}{c}{ Category } & $\begin{array}{c}\text { Previous esti- } \\
\text { mate (1974) }\end{array}$ & $\begin{array}{c}\text { Table 1 in } \\
\text { this report }\end{array}$ \\
\hline Recharge from irrigation & 85,000 & 82,000 \\
Recharge from precipitation & 203,000 & 82,000 \\
Recharge from subsurface inflow & 27,000 & unknown \\
Discharge to rivers & 130,000 & 95,000 \\
Discharge to diffuse seepage & not calculated & 22,000 \\
Discharge as evapotranspiration (ETg) of & 100,000 & 26,000 \\
$\quad$ groundwater & & \\
Discharge to springs & 80,000 & 74,000 \\
Discharge to wells & 4,000 & 11,000 \\
\hline
\end{tabular}

are approximately two orders of magnitude larger (Bjorklund and McGreevy, 1974, p. 17 and tables 11 and 12). The estimates of recharge from irrigation are essentially equal in both budgets. The previous estimate was calculated by using the measured water-level rise during the growing season. The rise was multiplied by the irrigated area and divided by an effective porosity of 0.15 to determine recharge volume (Bjorklund and McGreevy, 1974, p. 17). The current estimate is based on water-balance calculations (table 3 ).

\section{Numerical Groundwater Flow Model}

Numerical groundwater flow models simulate recharge, discharge, and aquifer properties in a groundwater flow system and provide a better understanding of the integrated system than can the study of individual components. The groundwater model in the Malad-Lower Bear River study area was developed to help assess the reduction in streamflow and other natural discharge with increasing groundwater development. The model used for this analysis is a refined version of the steady-state numerical groundwater flow model of the Great Basin carbonate and alluvial aquifer system (GBCAAS; Brooks and others, 2014), which is referred to as GBCAAS v. 1.0 in this report.

\section{Hydrographic Areas}

This section of the report uses hydrographic areas (HAs) as a basis for describing locations, naming model observations, and presenting groundwater budgets for consistency with previously published reports about the Great Basin carbonate and alluvial aquifer system (Heilweil and Brooks, 2011; Brooks and others, 2014). Most HAs represent a single watershed, including both basin fill and adjacent mountain blocks up to the topographic divide (Harrill and Prudic, 1998); some HAs, however, are arbitrary (Welch and others, 2007). This study uses the naming and numbering convention for HAs used by Harrill and others (1988). The study area is primarily within the Utah portion of the Malad-Lower Bear River Area (HA 273; fig. 18).

\section{MODFLOW-LGR}

The model presented in this report uses MODFLOW-LGR (Mehl and Hill, 2013), which allows for local grid refinement (LGR) within a larger regional model (fig. 19). Modifications to the model allow it to simulate the large regional system in mostly the same way as GBCAAS v. 1.0 (Brooks and others, 2014), but add detail to recharge, discharge, and aquifer properties within most of the Malad-Lower Bear River study area. MODFLOW-LGR provides the capability to simulate groundwater flow by using one or more block-shaped, higher resolution local grids (child model) within a coarser grid (parent model) by iteratively coupling separate MODFLOW-2005 


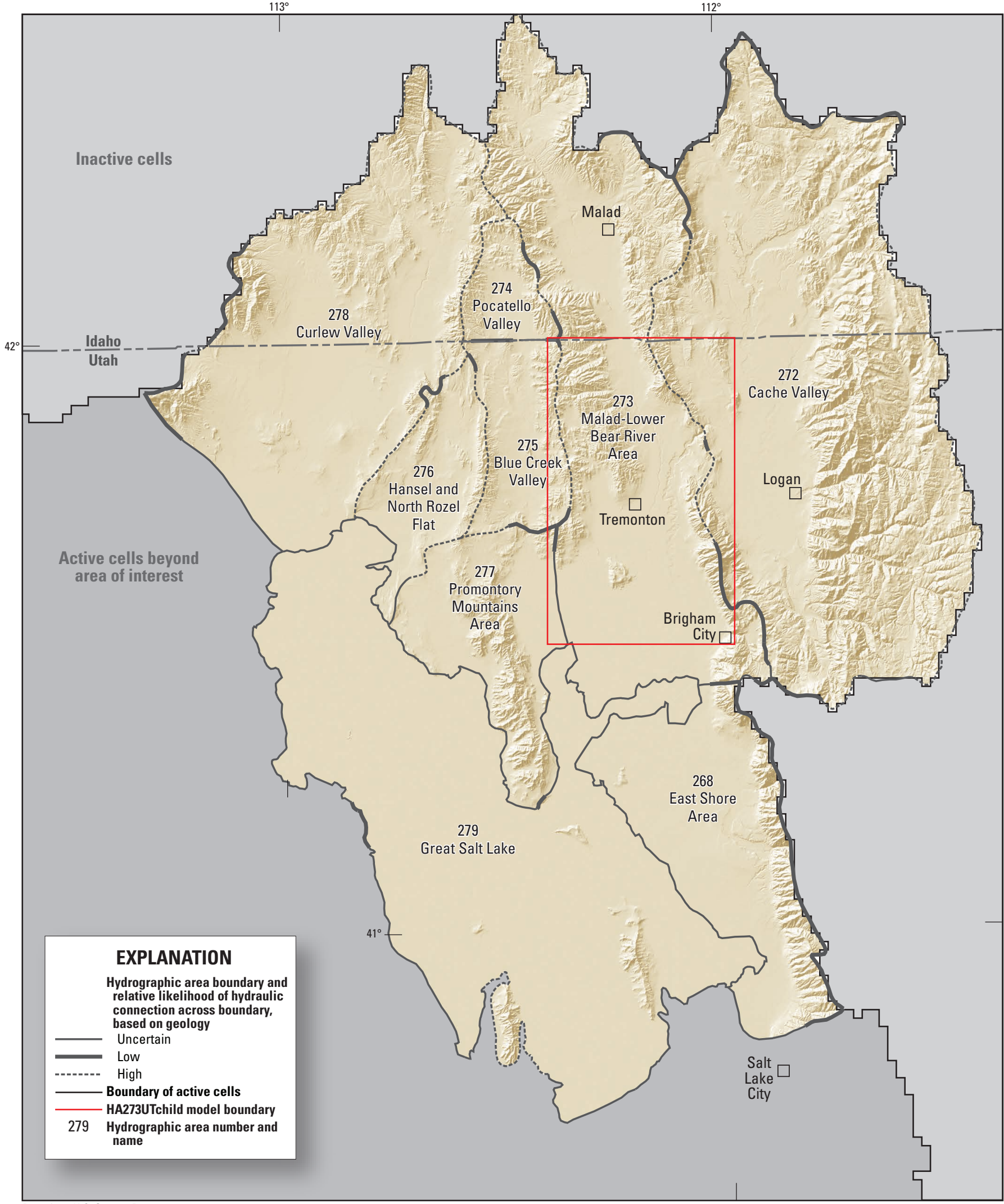

Albers Equal Area Conic Projection, Central Meridian $-114^{\circ}$

Standard Parallels at $29.5^{\circ}$ and $45.5^{\circ}$, Latitude of Origin $23^{\circ}$,

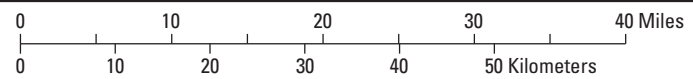

Figure 18. Hydrographic areas near the Malad-Lower Bear River study area, Utah and Idaho. 


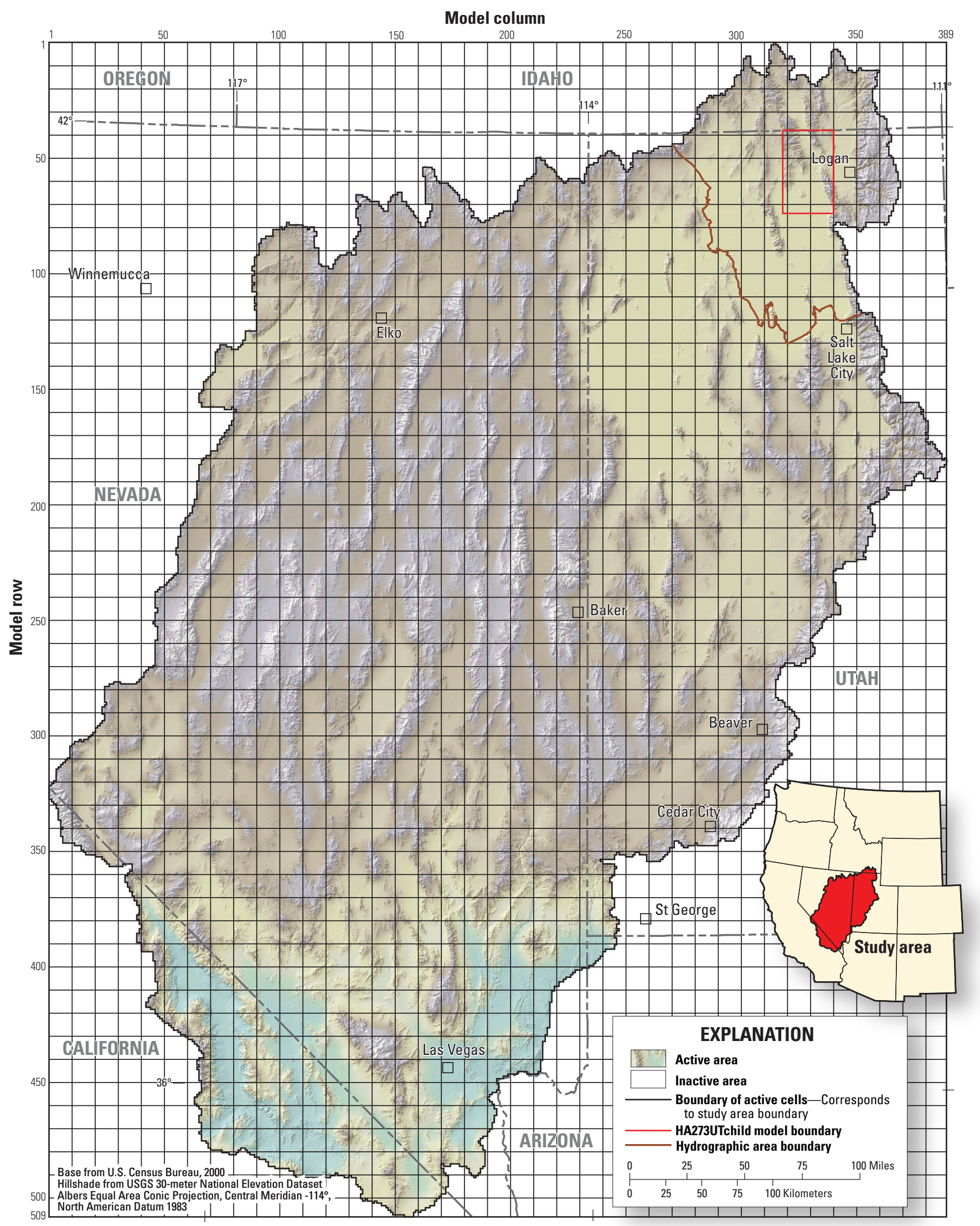

Figure 19. Location of the Great Basin carbonate and alluvial aquifer system (GBCAAS) groundwater model and area of local grid refinement, Malad-Lower Bear River study area. 
models such that heads and fluxes are balanced across the shared interfacing boundaries. The parent and child models can be run either as a coupled system of models or separately, as independent models. The parent model should not be run separately to examine model results within, or near, the child model. The model will be referred to as GBCAAS v. 2.0 in this report, and the terms "GBCAASv2parent model" and "HA273UTchild model" will describe the regional model and refined area, respectively.

Advantages of refining GBCAAS v. 1.0 instead of using a separately constructed model of the study area include the following: (1) the regional model accounts for subsurface inflow to and outflow from the study area, (2) projected withdrawals are not as likely to reach a simulated no-flow boundary which would artificially increase the simulated drawdown and effects on natural discharge within the study area, and (3) effects of withdrawals or other stresses within the study area on other areas are simulated. Calibrating the regional model to achieve adequate calibration in the study area, in the northern part of the Malad-Lower Bear River Area (HA 273) in Idaho, in Cache Valley (HA 272) east of the study area, and in Blue Creek Valley (HA 275) and the Promontory Mountains Area (HA 277) west of the study area probably required a different distribution of recharge and hydraulic conductivity than would have been derived by assuming no-flow boundaries at the surface-water divide of the study area.

Advantages of using LGR to refine the grid within the study area include the following: (1) stresses can be simulated more specifically where they occur; (2) hydraulic properties can change across smaller areas; and (3) altitude of rivers, springs, field drains, and evapotranspiration can be more accurately simulated. For the purpose of illustrating the reduction in groundwater discharge to rivers and springs with increasing groundwater development, the smaller grid and other refinements increase the precision of the maps developed to help guide management decisions regarding groundwater withdrawals.

\section{Existing Great Basin Carbonate and Alluvial Aquifer System Model}

GBCAAS v. 1.0 (Brooks and others, 2014) was constructed by using MODFLOW-2005 (Harbaugh, 2005) and simulates the groundwater system in about $110,000 \mathrm{mi}^{2}$ of Utah, Nevada, California, Idaho, and Arizona (fig. 19). Model construction, discretization, recharge, discharge, and MODFLOW packages used are described in Brooks and others (2014) and are summarized here. The model simulates steady-state pre-pumping conditions and consists of 509 rows, 389 columns, and 8 layers. Model grid rows are oriented in an east-west direction, and model grid columns are oriented in a north-south direction. Model grid spacing is $1 \mathrm{mi}$ in both the north-south and east-west directions. GBCAAS v. 1.0 was used to develop six simulated groundwater regions (fig. 20) that connect recharge areas to discharge areas (Brooks and others, 2014, p. 73). The study area is in the Great Salt Lake region.
Although the top of the groundwater system is unconfined, all model layers were designated confined because simulating layer 1 as unconfined caused numerical instability. For a steady-state model, the only consequence of simulating layer 1 as confined is that the transmissivity of the layer does not change with changes in simulated water level. Simulating layer 1 as confined is a reasonable approximation if the top of the simulated saturated thickness is close to the specified saturated thickness (Reilly and Harbaugh, 2004, p. 15). The top of the model and thicknesses of layers were adjusted during calibration to allow the top of the model to be close in altitude to simulated water levels and to ensure that the bottom of layer 1 is lower than simulated heads and the top of layer 1 is never above land surface as defined by the National Elevation Dataset (NED) available from the USGS (U.S. Geological Survey EROS Data Center, 1999). In areas where the bottom of layer 1 was lowered from the original discretization, the bottom altitudes of layers 2 through 6 were also lowered as needed to ensure that the layers are at least $10 \mathrm{ft}$ thick at all locations.

Unconsolidated basin fill and consolidated rock are modeled as a connected system, with most of the recharge occurring on consolidated rock in the mountains and most discharge occurring as ETg in the basins. The model simulates recharge from precipitation and from irrigation with surface water. Irrigation recharge was assigned to generalized areas within each HA with irrigation from surface water, not to specific fields or crops. Recharge from rivers and canals is not explicitly simulated, but the estimated amount is applied as areal recharge on selected cells in each HA. The model simulates groundwater discharge to ETg and to selected springs, rivers, and lakes. Impermeable boundaries are assumed below an altitude of $-12,000 \mathrm{ft}$ and along most lateral boundaries (fig. 19; Brooks and others, 2014, pl. 1).

The nine hydrogeologic units (HGUs) described in Sweetkind and others (2011) are the basis for assigning horizontal hydraulic conductivity and vertical anisotropy to the model layers. HGUs representing consolidated, pre-Cenozoic rocks, in stratigraphic order from deepest to shallowest, include (1) a non-carbonate confining unit (NCCU) representing lowpermeability Precambrian siliciclastic formations, and crystalline igneous and metamorphic rocks, (2) a lower carbonate aquifer unit (LCAU) representing high-permeability Cambrian through Devonian limestone and dolomite, (3) an upper siliciclastic confining unit (USCU) representing low-permeability Mississippian shale, and (4) an upper carbonate aquifer unit (UCAU) representing high-permeability Pennsylvanian and Permian carbonate rocks. For computational reasons in the construction of the framework, separate HGUs must be defined where the stratigraphic section is duplicated by largeoffset thrust faults (Sweetkind and others, 2011). In these situations, a thrusted non-carbonate confining unit (TNCCU) and a thrusted lower carbonate aquifer unit (TLCAU) are defined, representing low-permeability siliciclastic rocks and high-permeability limestone and dolomite, respectively. HGUs representing Cenozoic basin fill and volcanic rocks include a volcanic unit (VU) representing outcrop areas of volcanic 


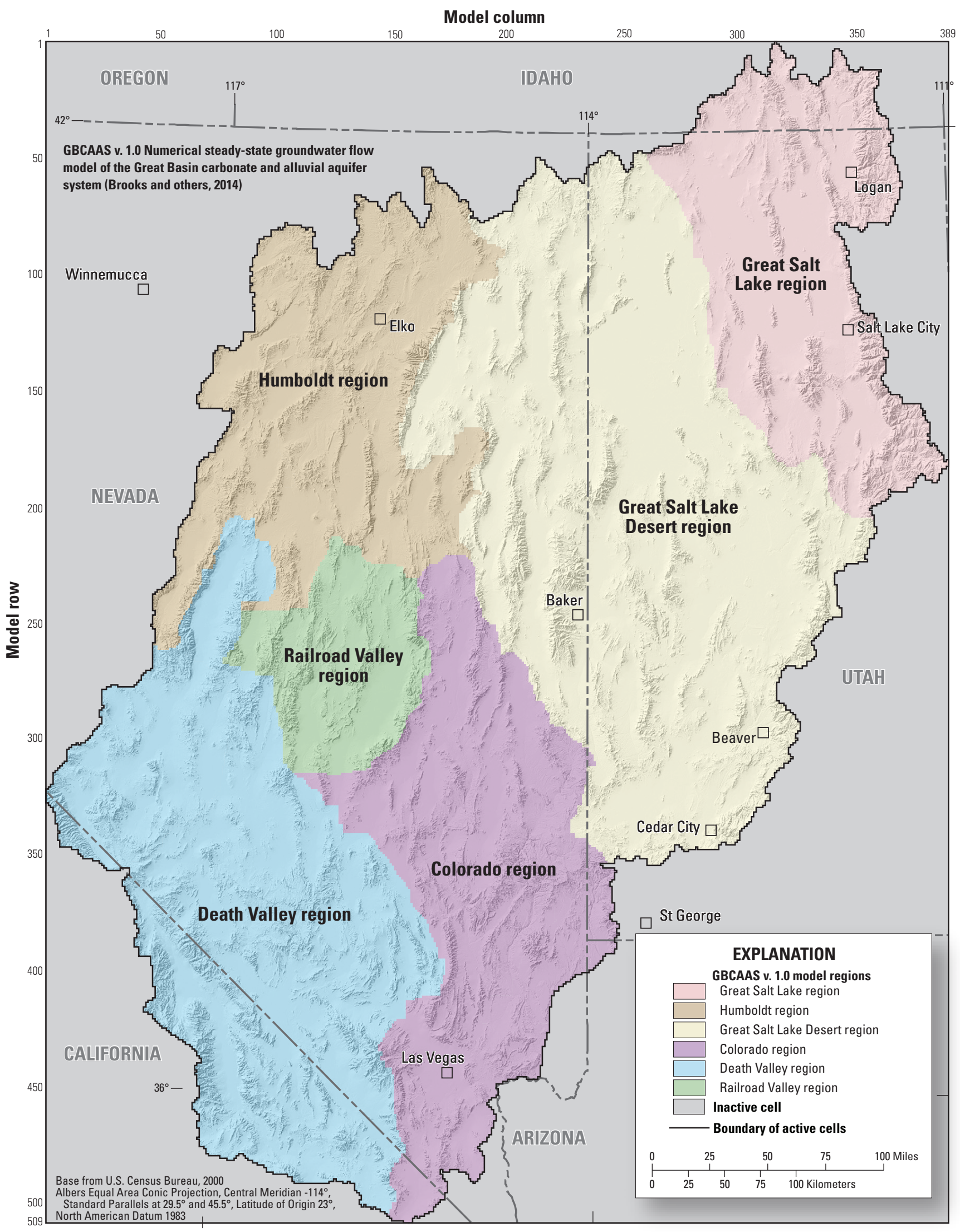

Figure 20. Simulated groundwater regions in the GBCAAS v. 1.0 groundwater model, Great Basin carbonate and alluvial aquifer system study area. 
rocks, a lower basin-fill aquifer unit (LBFAU) representing the lower one-third of the Cenozoic basin fill, and an upper basin-fill aquifer unit (UBFAU) representing the upper twothirds of the Cenozoic basin fill. The TNCCU, TLCAU, and VU HGUs do not exist in the Malad-Lower Bear River study area. The HGUs are simulated by using the HydrogeologicUnit Flow (HUF) Package (Anderman and Hill, 2000; 2003) of MODFLOW-2005, which can represent the complexities of the geology (Brooks and others, 2014, fig. 3). Hydrogeologic structures that act as barriers to groundwater flow were simulated by using the Horizontal-Flow Barrier (HFB) Package (Harbaugh, 2005, p. 5-21 to 5-22).

Although GBCAAS v. 1.0 (Brooks and others, 2014) was not constructed to represent each HA in detail, groundwater budgets and discharge observations are presented for simulated groundwater regions in Brooks and others (2014, tables 12 and $\mathrm{A} 3-1$ ), and groundwater budgets are presented for each HA in Brooks and others (2014, table A3-2). Several model observations were included in and around the MaladLower Bear River study area (Brooks and others, 2014). The model fit to the observations indicates that GBCAAS v. 1.0 provides an adequate representation of the regional flow in and around the study area. Because of the large cell size in GBCAAS v. 1.0 and the lack of delineation by Bjorklund and McGreevy (1974) of some of the amounts and locations of discharge, some discharges were combined and simulated using the Drain Package (Harbaugh, 2005, p. 6-12 to 6-15). Springs were grouped together into observations in GBCAAS v. 1.0 because the goal was to achieve discharge in the approximate location, not the exact location. Springs discharging less than 300 gallons per minute (gal/min; about 500 acre-ft/yr) were not included as discharge boundaries or observations in GBCAAS v. 1.0 unless they were part of a group of springs that had total discharge of greater than $300 \mathrm{gal} / \mathrm{min}$.

\section{Local Grid Refinement}

The large cell size of GBCAAS v. 1.0 limits the ability to simulate the correct location of rivers, springs, field drains, ETg, withdrawals, and projected withdrawals. MODFLOW-2005 makes all calculations at the center of model cells; using a $1-\mathrm{mi}^{2}$ cell size could simulate a withdrawal well that is almost $1 \mathrm{mi}$ from a river in the same cell as the river. This could cause simulated drawdown at the river, and the simulated effect on groundwater discharge to the river, to be unrealistically large.

For the study area, the grid was refined to be $0.2 \mathrm{mi}$ on each side for a grid-cell area of $0.04 \mathrm{mi}^{2}$ to provide better delineation of the rivers (fig. 21). This required changing the top of the model, the bottom and thicknesses of model layers, the top of each hydrogeologic unit (HGU) in the model, and the thickness of the bottom HGU to reflect the finer discretization of the land surface. Additional vertical layers were not added to the HA273UTchild model, but the vertical discretization of model layers allows adequate definition to simulate vertical gradients. The UBFAU is represented by several model layers and the layer thicknesses are sufficiently thin near the rivers to vertically separate the discharge to rivers from deeper withdrawals (figs. 22 and 23). In addition to refining the grid, boundary conditions were changed throughout the child model. These changes were necessary to match the refined grid, to match the conceptual groundwater budget described in this report, and to cause simulated values of groundwater discharge to match observed values more closely. These changes are documented in the following sections.

\section{Boundary Conditions}

The boundaries chosen for the model describe mathematically how the simulated groundwater system interacts with the surrounding hydrologic system. Mathematical boundaries used to represent hydrologic boundaries in the child model include specified-flow boundaries and head-dependent flow boundaries (Reilly, 2001, p. 1). These boundaries define both the physical limits of the model and how recharge to and discharge from the groundwater system are simulated. Boundary conditions in the GBCAASv2parent model are mostly the same as in GBCAAS v. 1.0 (Brooks and others, 2014). This report describes boundary conditions in the HA273UTchild model and changes in boundary conditions from GBCAAS v. 1.0 to the GBCAASv2parent model (appendix 5).

\section{Specified-Flow Boundaries}

Specified-flow boundaries allow a specified rate of water into or out of a cell and are used to simulate recharge from precipitation, ephemeral streams, and irrigation; discharge to wells; and the physical boundary at the bottom of the model. The boundary at the bottom of the model is a no-flow boundary, which is a specified-flow boundary with a flow of zero.

\section{Recharge from Precipitation, Ephemeral Streams, and Irrigation}

Recharge from precipitation and ephemeral streams (runoff from precipitation) is simulated as a specified-flux boundary with the Recharge Package (Harbaugh, 2005, p. 6-2 to 6-4); applied to the highest active cell (always layer 1 in this model); and defined using multiplier arrays, zones, and parameters (Harbaugh, 2005). Three multiplier arrays define (1) recharge that occurs in-place from rainfall and snowmelt, (2) recharge that occurs from runoff in intermittent and ephemeral streams, and (3) recharge that occurs from mountain-stream baseflow in streams that enter the basins (does not exist within the HA273UTchild model). The sources of recharge were separated for consistency with Masbruch and others (2011, table D-1) and Brooks and others (2014). Recharge parameters are used to multiply these conceptual rates and to apply the rates to specific zones (table A4-1). 


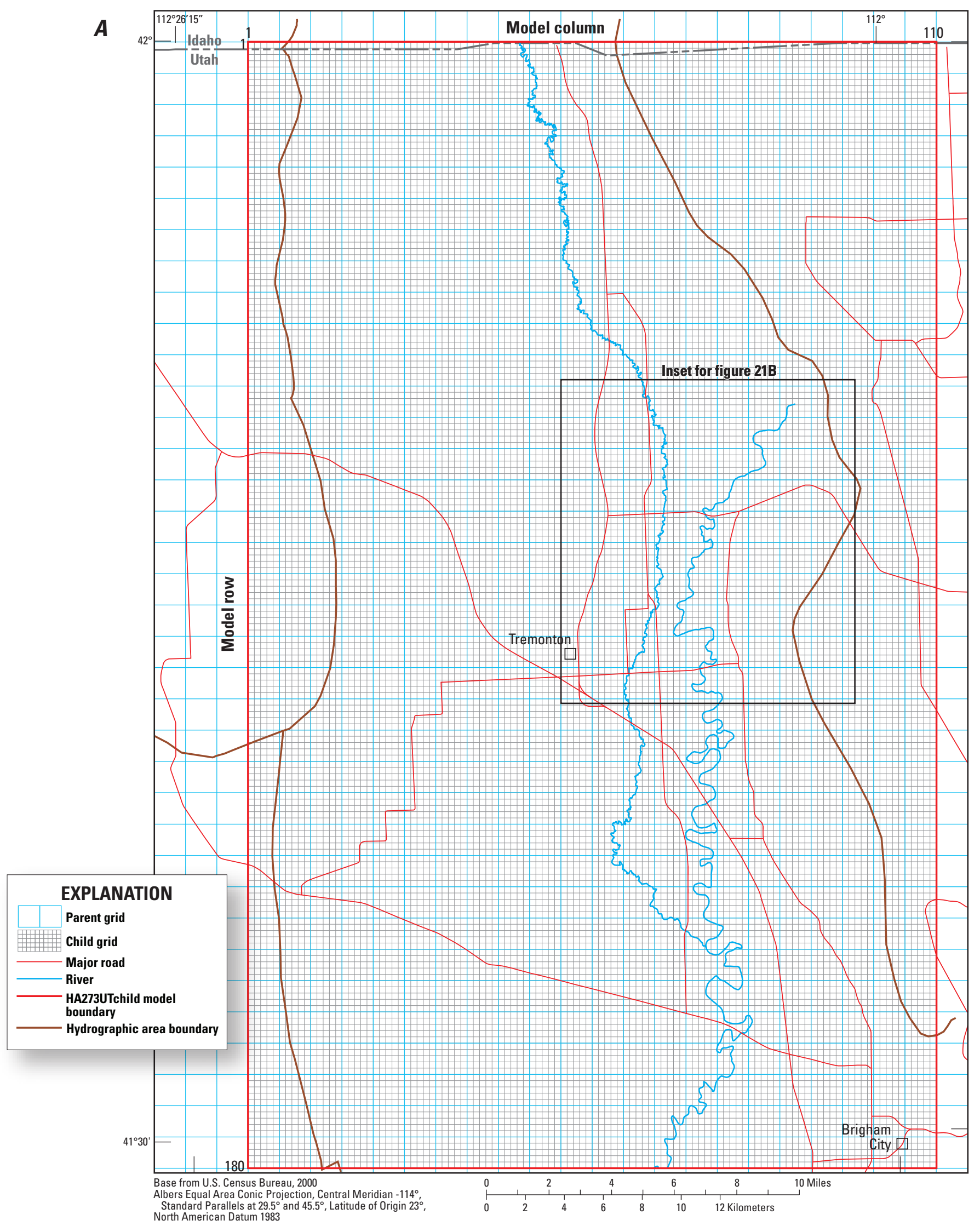

Figure 21. Model grid refinement for the HA273UTchild model, Malad-Lower Bear River study area. A, study area and HA273UTchild model grid, and $B$, delineation of rivers in the HA273UTchild model. 
B 51

Model column

97

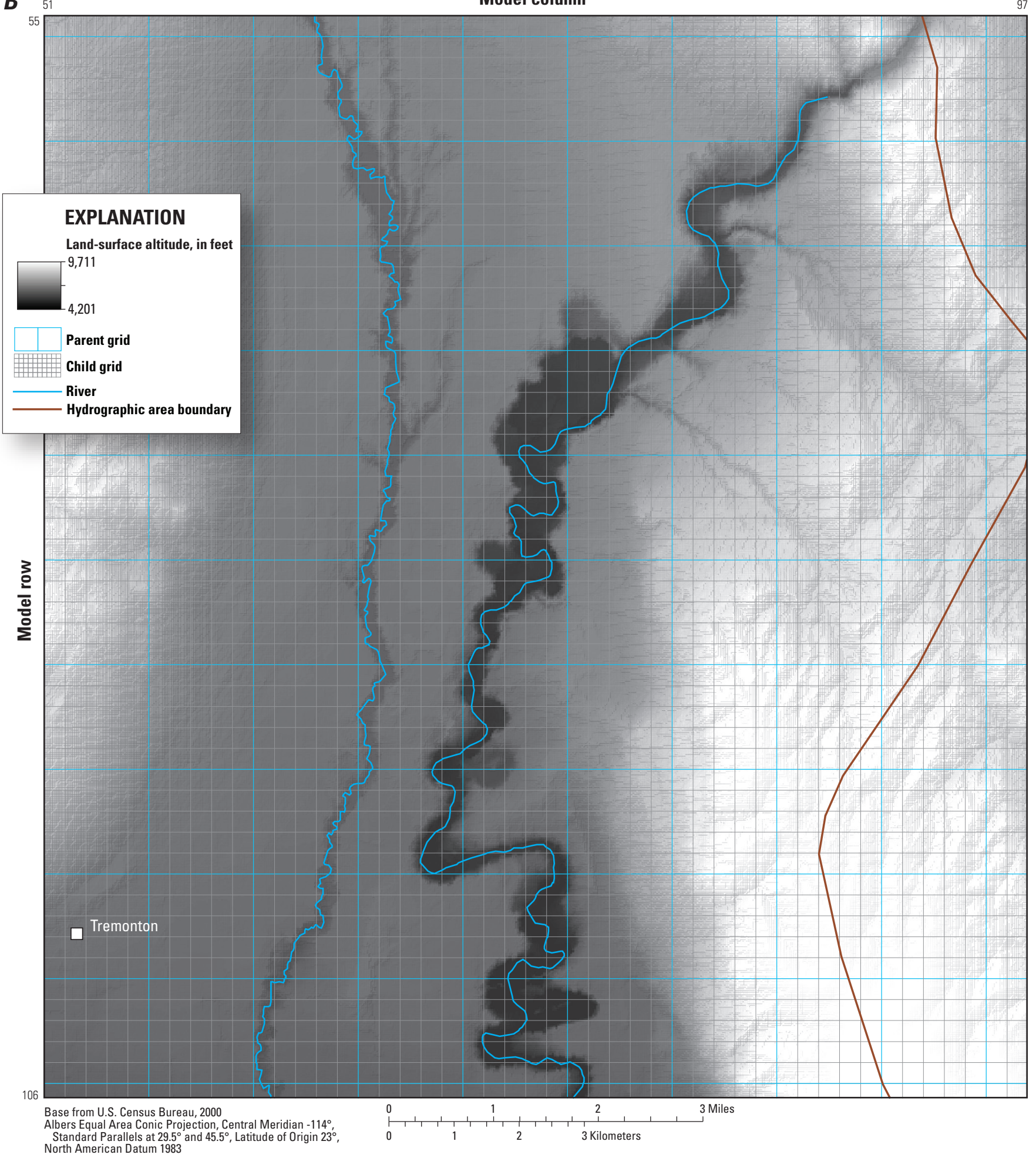

Figure 21. Model grid refinement for the HA273UTchild model, Malad-Lower Bear River study area. A, study area and HA273UTchild model grid, and B, delineation of rivers in the HA273UTchild model.-Continued 


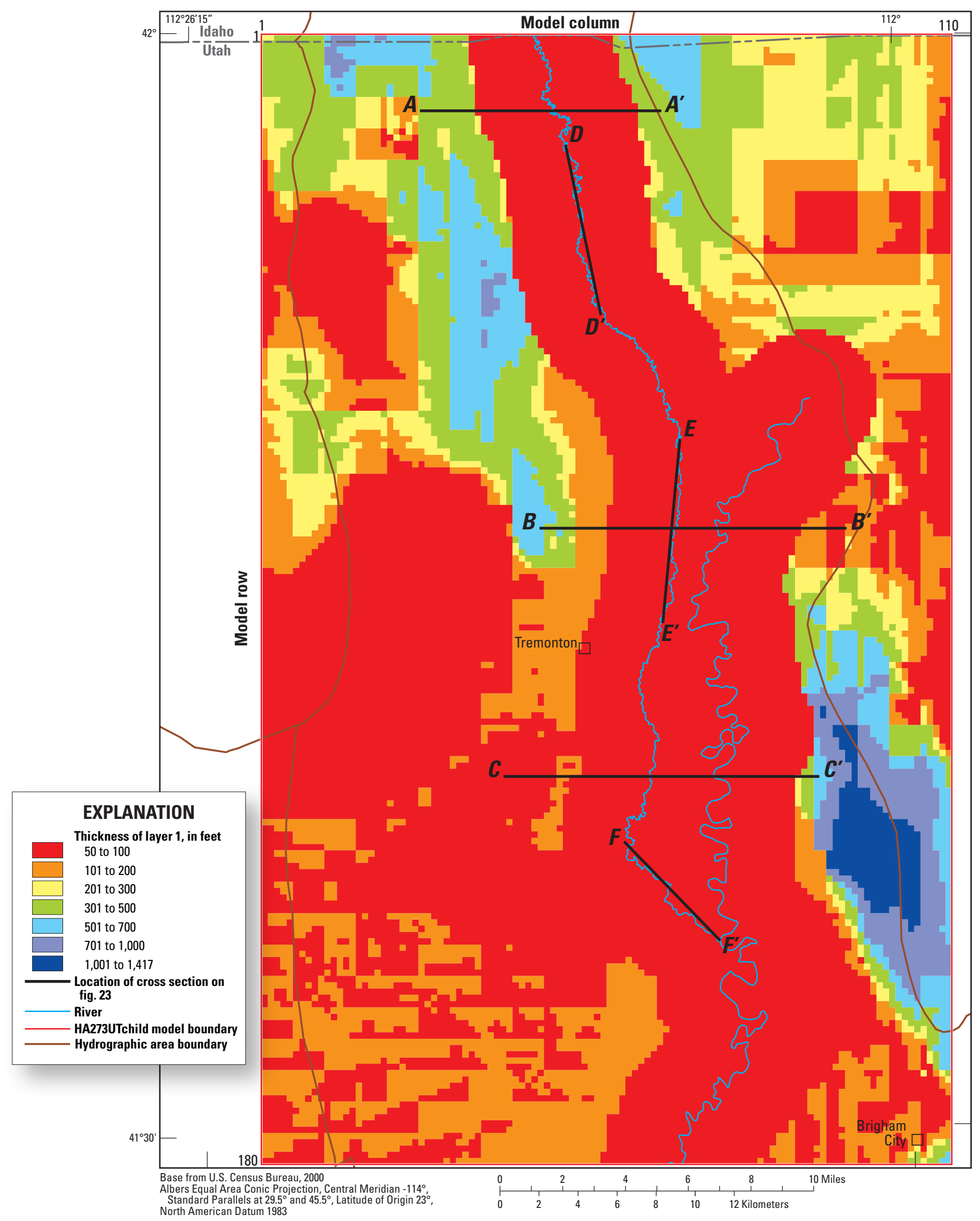

Figure 22. Thickness of layer 1 in the HA273UTchild model and location of cross sections, Malad-Lower Bear River study area. 


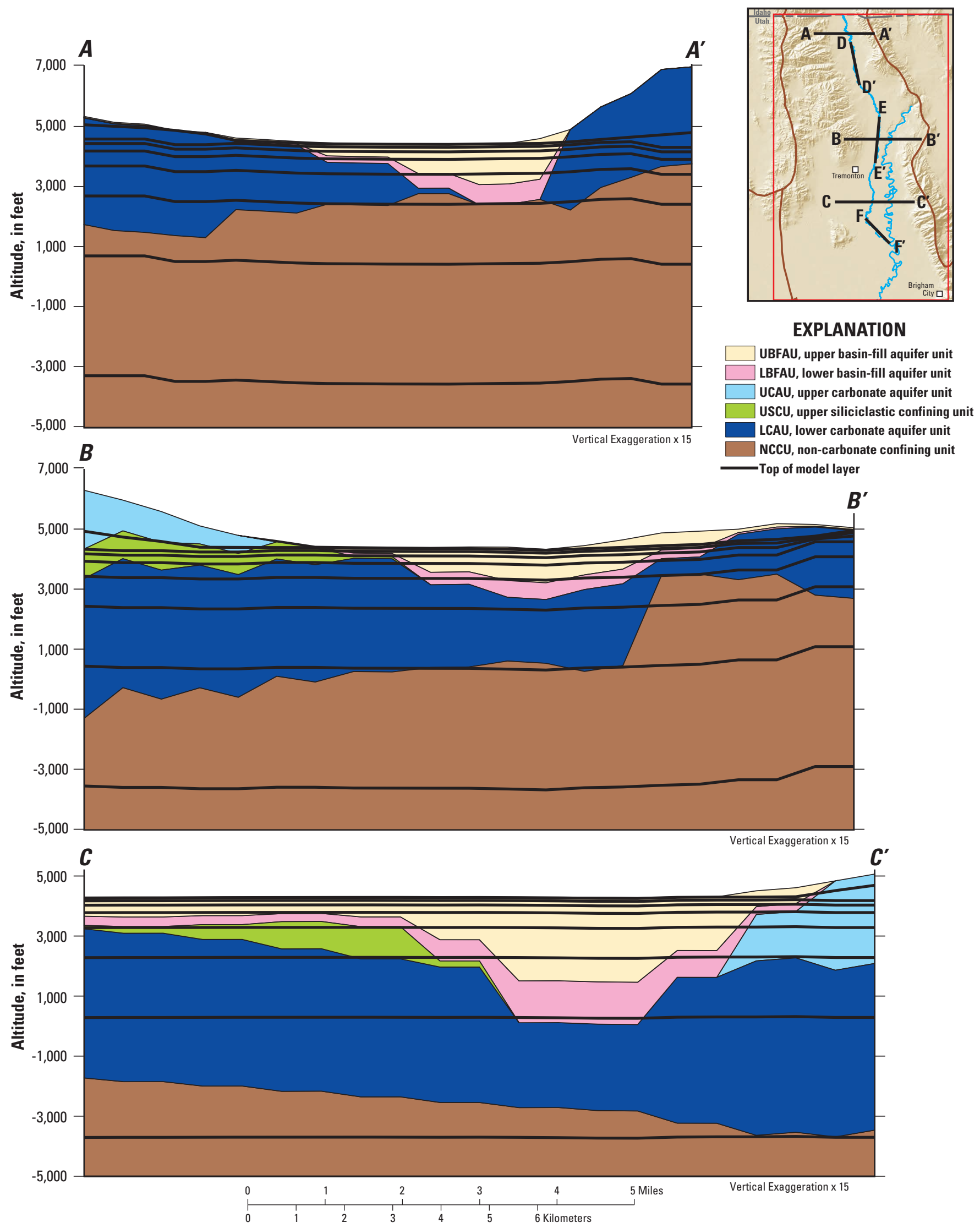

Figure 23. Model layer and hydrogeologic thicknesses in the HA273UTchild model, Malad-Lower Bear River study area. 

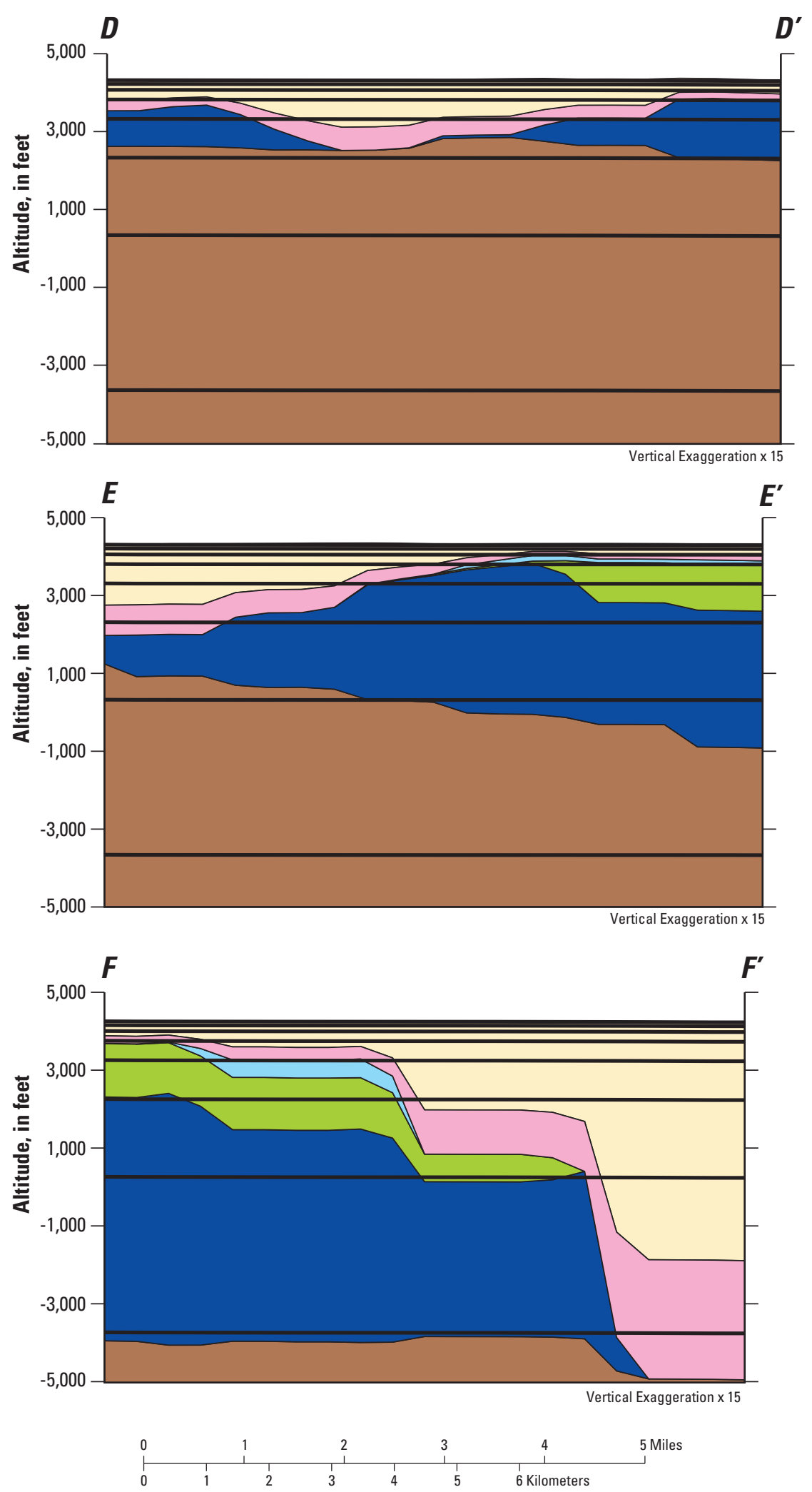

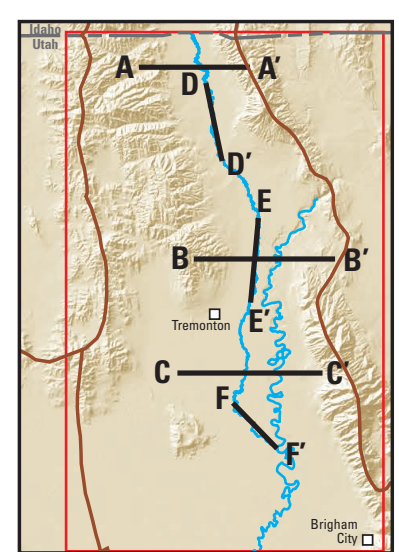

\section{EXPLANATION}

UBFAU, upper basin-fill aquifer unit LBFAU, lower basin-fill aquifer unit UCAU, upper carbonate aquifer unit USCU, upper siliciclastic confining unit LCAU, lower carbonate aquifer unit NCCU, non-carbonate confining unit Top of model layer

Figure 23. Model layer and hydrogeologic thicknesses in the HA273UTchild model, Malad-Lower Bear River study area. —Continued 
Recharge from precipitation was calculated by using the results of the Basin Characterization Model (BCM) average annual recharge and runoff from 1940-2006 (Flint and others, 2011; Masbruch and others, 2011, p. 76). The BCM divides available water into "in-place recharge" and "runoff." In GBCAAS v. 1.0 and GBCAAS v. 2.0, BCM in-place recharge is simulated at the same location as it occurs in the BCM model (fig. 24A), but was resampled from a 270-m grid to the 1-mi model grid using bilinear interpolation. The conceptual distribution of in-place recharge (multiplier array "rech_inplace") was not changed from GBCAAS v. 1.0 to the GBCAASv2parent model or most of the HA273UTchild model, but was changed to 0 in 26 child cells to prevent recharge on cells simulating the Bear River.

The BCM does not route runoff, but distributes runoff at the location it is generated (fig. 24B). In GBCAAS v. 1.0, runoff at higher altitudes was typically redistributed to model cells along the mountain front that contained unconsolidated basin-fill material with a slope of 5 to 10 percent (fig. 24C); in this way, upland runoff was accounted for as recharge where streams enter valleys. During this redistribution of recharge from runoff, the percent of runoff that becomes recharge was calculated as either 10 or 30 percent (Masbruch and others, 2011, p. 86 and fig. D-7). Thirty percent of the runoff is estimated to become recharge within the study area.

Two major changes were made within the HA273UTchild model to distribute recharge from runoff more realistically within the study area and parts of Cache Valley (HA 273). First, very little runoff is used for irrigation, so the runoff was concentrated at model cells near the mountain fronts (fig. 24C). Second, the amount of recharge from runoff was distributed at the mountain front closer to where it is generated in the BCM, rather than applying an average over the study area. In the Cache Valley (HA 273) part of model area where rates were changed, recharge parameters were set to large values to simulate the same rate of recharge as in the GBCAAS v. 1.0 model. Recalibrating the model outside of the study area to match more refined stresses was beyond the scope of this study.

In the GBCAAS v. 1.0 model, recharge from mountain stream baseflow (fig. 24D) was distributed to the same cells as recharge from runoff, but does not occur in every HA (Masbruch, 2011a, table A4-1). During this study, it was determined that there is little baseflow in mountain streams within the study area (see "Surface Water and Springs" section of this report), and recharge from baseflow was removed from the HA273UTchild model.

Recharge from irrigation is included in the "recharge from imported water" multiplier because most of the irrigation water originates outside of the study area and enters the study area through canals from the Bear River. Recharge from irrigation in the HA273UTchild model was changed substantially from GBCAAS v. 1.0. First, the area of recharge simulated in GBCAAS v. 1.0 included areas that are not irrigated with canal diversions from the Bear and Malad Rivers; this was caused by the rough estimate of irrigated areas on the basis of land slope of between 5 and 10 percent (Brooks and others, 2014, p. 20). In the HA273UTchild model, only the areas that are supplied by canals are included in the areas that have recharge from imported water (fig. 24E). Second, the scope of the GBCAAS study (Heilweil and Brooks, 2011) did not include detailed analysis of the amount of applied water for each HA. In the study area, the GBCAAS study assumed that all of the Bear River near Collinston (fig. 1 and "Surface Water and Springs" section of this report) was diverted for irrigation in the Malad-Lower Bear River Area (HA 273) and that 30 percent of that became recharge. The estimated $330,000 \mathrm{acre}-\mathrm{ft} / \mathrm{yr}$ of recharge (Masbruch, 2011a) greatly exceeds the effective applied water of 160,000 acre-ft/yr and recharge of 82,000 acre-ft/yr estimated during this study (table 3). The total conceptual recharge is the summation of inplace recharge, recharge from runoff, recharge from baseflow (GBCAASv2parent model only), and recharge from imported (irrigation) water (fig. 24F).

\section{Wells}

The average annual withdrawal from municipal and irrigation wells was simulated by using the Well Package (Harbaugh, 2005, p. 6-1 to 6-2). The Well Package simulates a specified stress at the row, column, and layer of each well (fig. 25). The discharge from each layer for each well was assumed to be proportional to the length of the screened interval in each layer. No wells are simulated in layers deeper than layer 4. Although this is a steady-state model, the wells were added because the system appears to be in steady-state; the well withdrawals are a small part of the water budget (table 1), and it is likely that their impact on groundwater discharge has been too small to measure. The accuracy of maps showing the effects of projected withdrawals, however, may be improved by accounting for current withdrawals in the model. For consistency with other areas, wells were not added to the GBCAASv2parent model, even within the study area.

\section{Head-Dependent Boundaries}

Most discharge from the groundwater system in the study area occurs as discharge to rivers, springs, field drains, and ETg (table 1); these discharge processes are simulated by using head-dependent flow boundaries. In cells with a headdependent boundary, groundwater is simulated as discharging from a cell when the simulated head is above the specified boundary altitude. The rate of discharge is determined by the difference in simulated water level and boundary altitude and by the boundary conductance. Because multiple head-dependent boundaries in a single model cell can cause numerical instability, only one boundary is simulated in each cell with a head-dependent boundary. Generally in the HA273UTchild model, the order of priority for assigning discharge to a specific observation was as follows: individual springs, rivers, field drains, and ETg. This allowed the model boundary conditions to be the most specific. Selected small springs were included with rivers or ETg (table A3-5). 


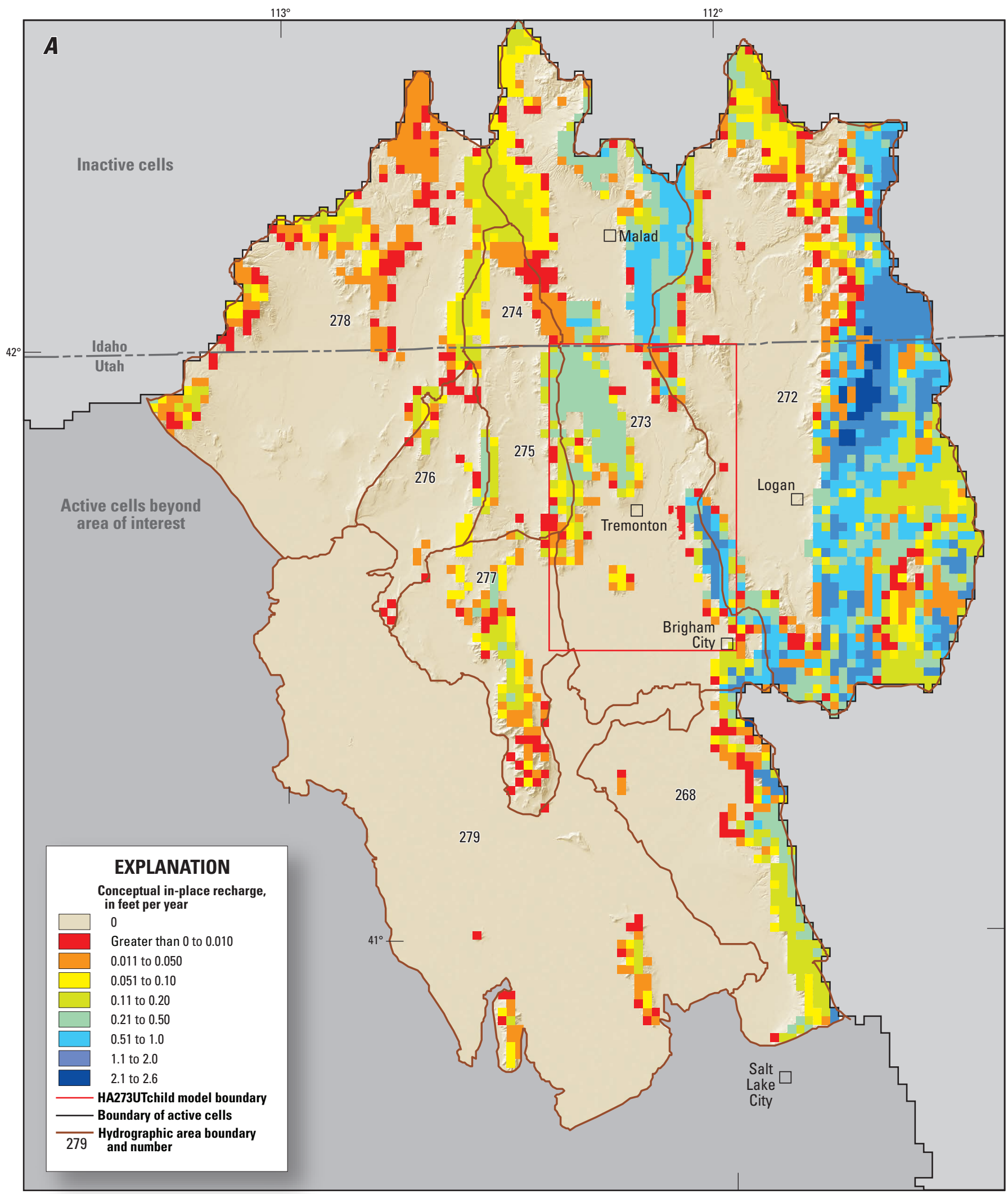

Base from U.S. Census Bureau, 2000

Albers Equal Area Conic Projection, Central Meridian $-114^{\circ}$

Standard Parallels at $29.5^{\circ}$ and $45.5^{\circ}$, Latitude of Origin $23^{\circ}$,

North American Datum 1983

Figure 24. Rates of conceptual recharge and runoff from various sources, Malad-Lower Bear study area and surrounding areas, Utah and Idaho. $A$, in-place recharge, $B$, runoff, $C$, recharge from runoff, $D$, recharge from baseflow, $E$, recharge from imported water, and $F$, total conceptual recharge. 


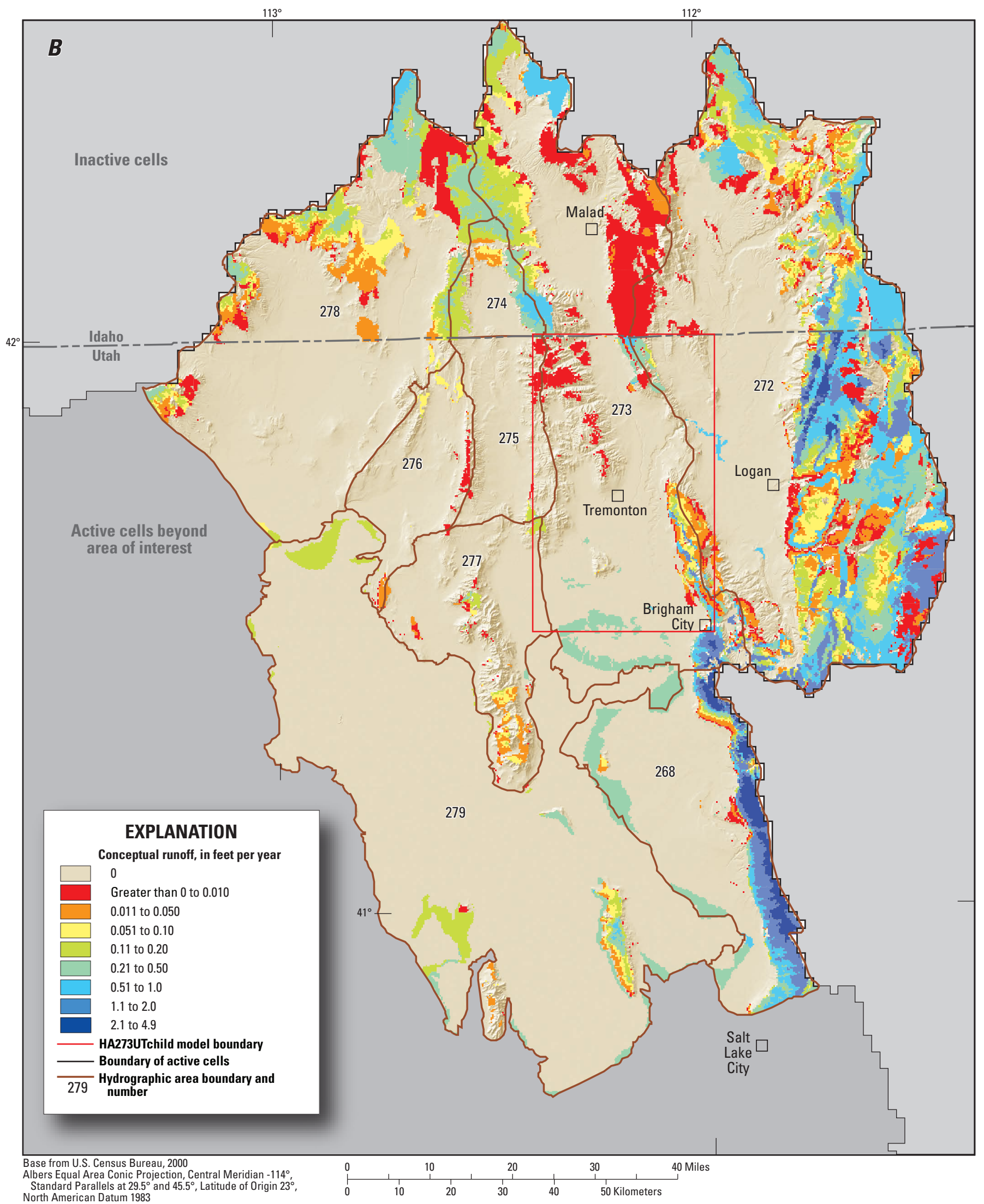

Figure 24. Rates of conceptual recharge and runoff from various sources, Malad-Lower Bear study area and surrounding areas, Utah and Idaho. $A$, in-place recharge, $B$, runoff, $C$, recharge from runoff, $D$, recharge from baseflow, $E$, recharge from imported water, and $F$, total conceptual recharge.-Continued 


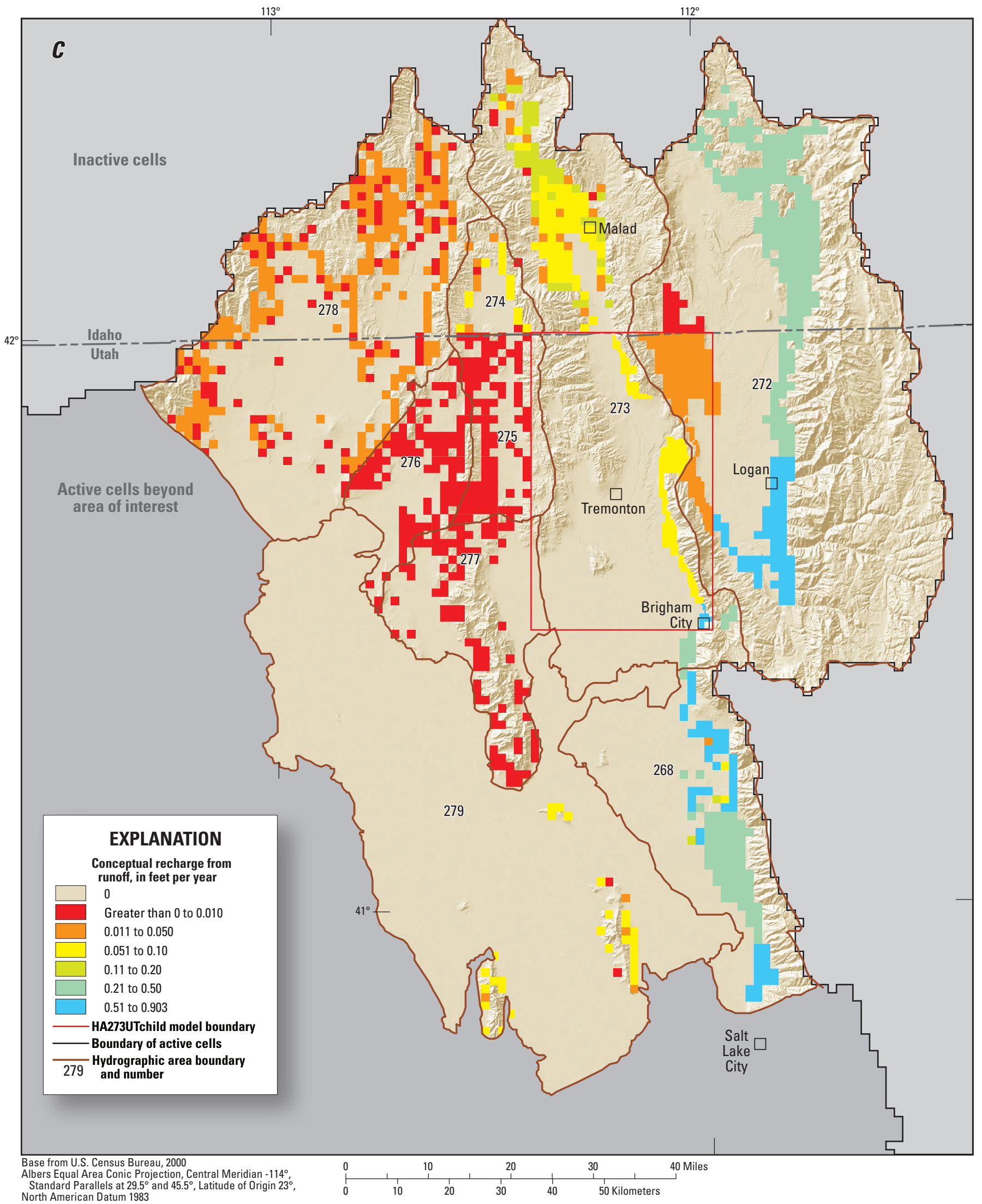

Figure 24. Rates of conceptual recharge and runoff from various sources, Malad-Lower Bear study area and surrounding areas, Utah and Idaho. $A$, in-place recharge, $B$, runoff, $C$, recharge from runoff, $D$, recharge from baseflow, $E$, recharge from imported water, and $F$, total conceptual recharge.-Continued 


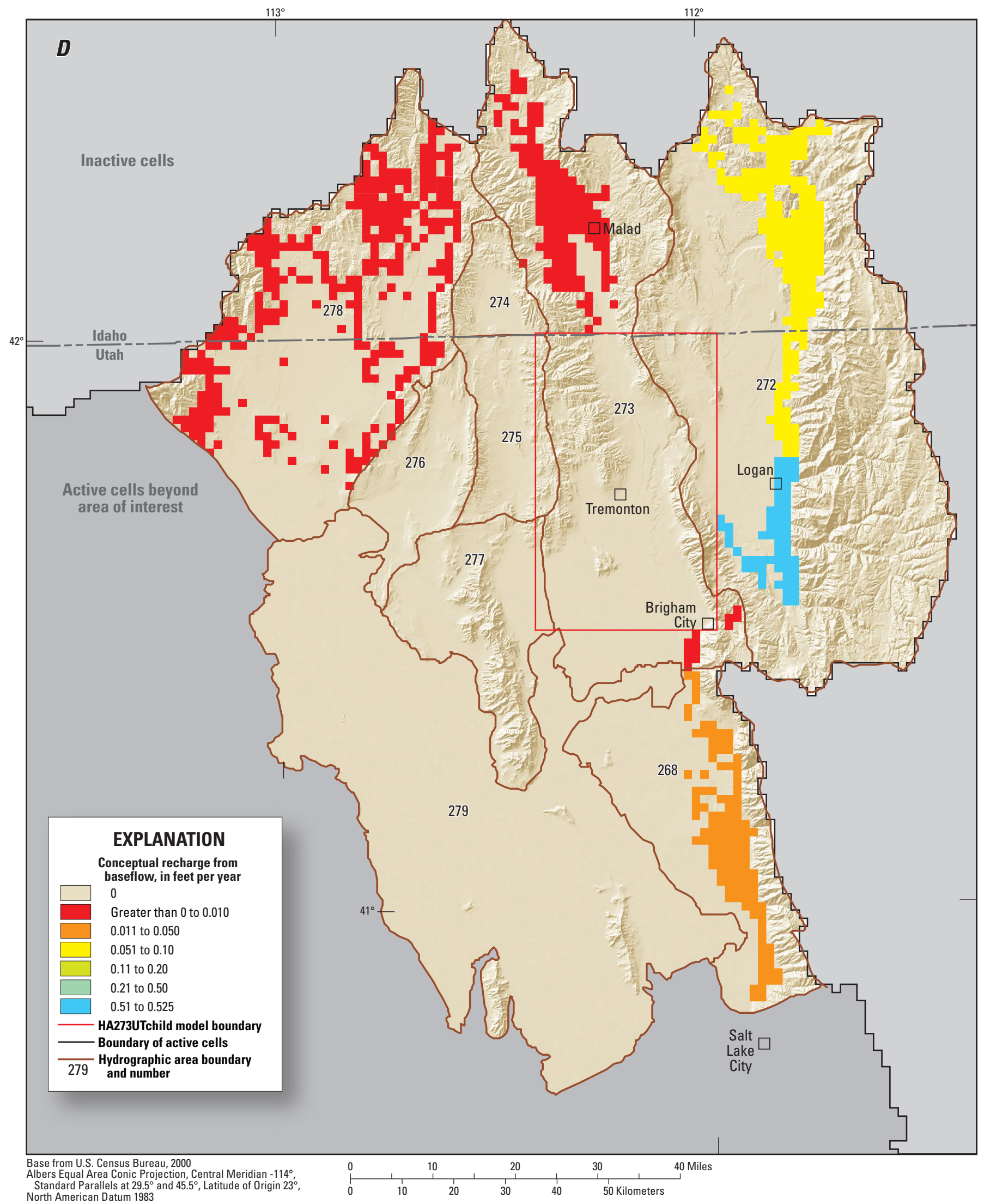

Figure 24. Rates of conceptual recharge and runoff from various sources, Malad-Lower Bear study area and surrounding areas, Utah and Idaho. $A$, in-place recharge, $B$, runoff, $C$, recharge from runoff, $D$, recharge from baseflow, $E$, recharge from imported water, and $F$, total conceptual recharge.-Continued 


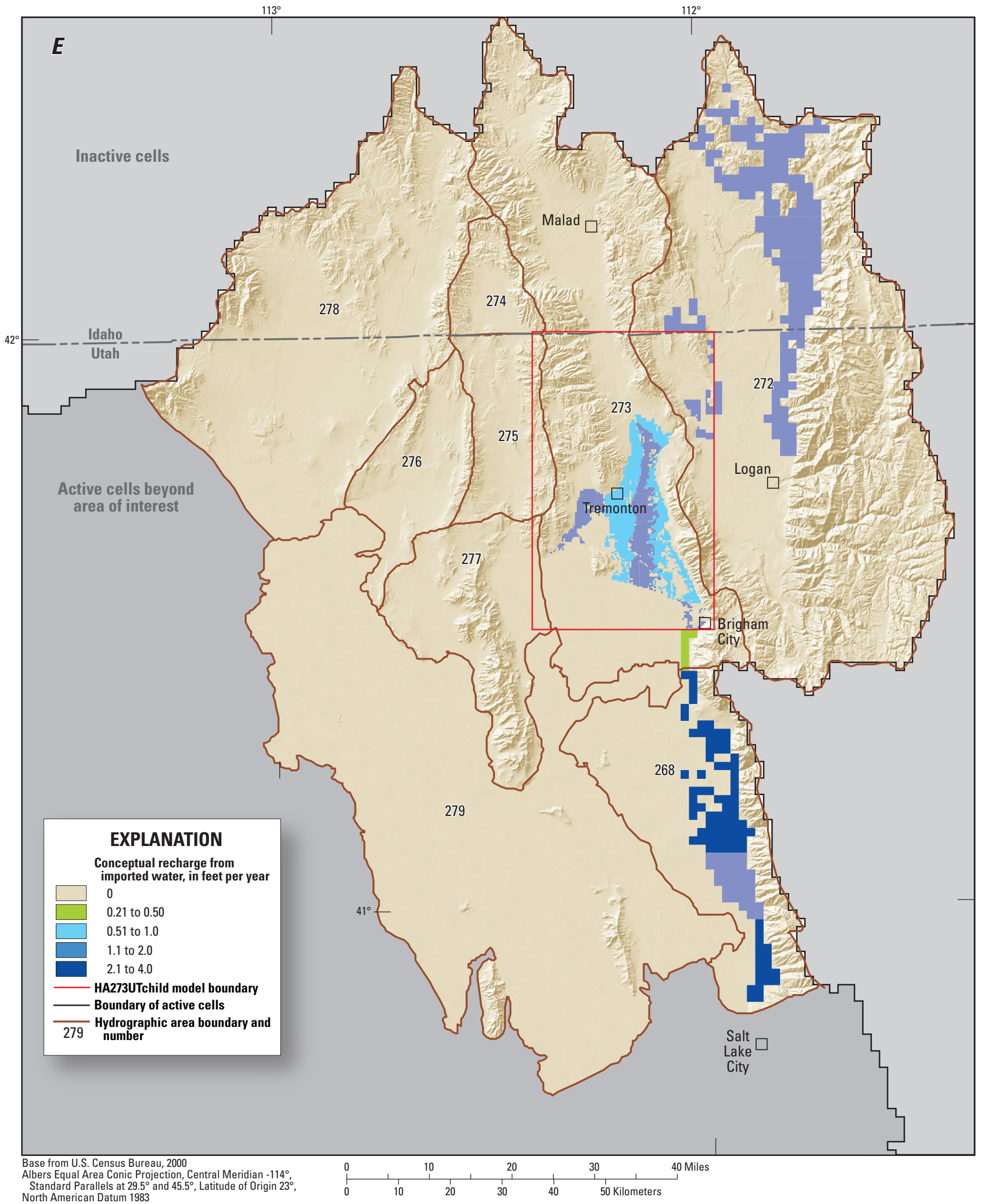

Figure 24. Rates of conceptual recharge and runoff from various sources, Malad-Lower Bear study area and surrounding areas, Utah and Idaho. $A$, in-place recharge, $B$, runoff, $C$, recharge from runoff, $D$, recharge from baseflow, $E$, recharge from imported water, and $F$, total conceptual recharge.-Continued 


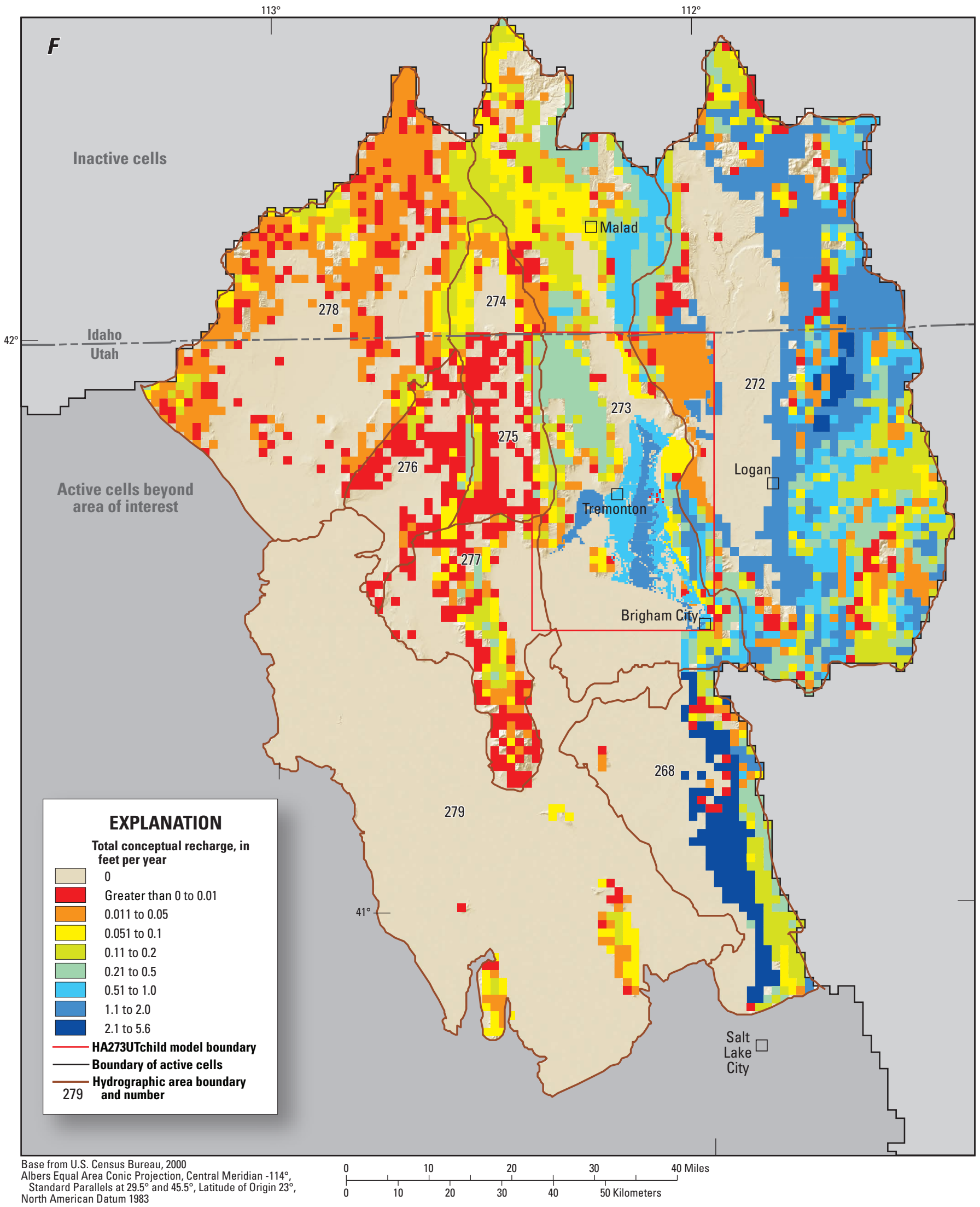

Figure 24. Rates of conceptual recharge and runoff from various sources, Malad-Lower Bear study area and surrounding areas, Utah and Idaho. $A$, in-place recharge, $B$, runoff, $C$, recharge from runoff, $D$, recharge from baseflow, $E$, recharge from imported water, and $F$, total conceptual recharge.-Continued 


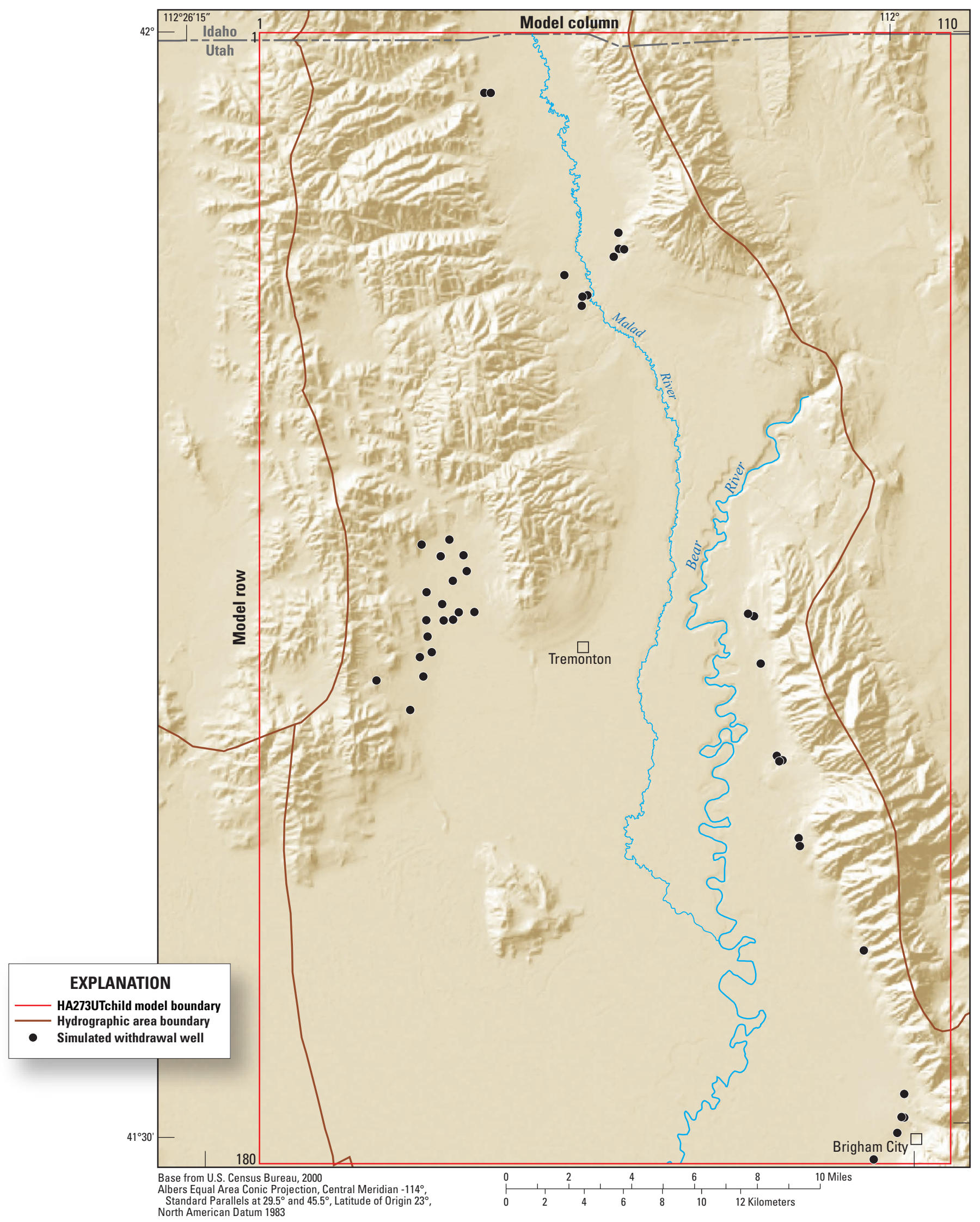

Figure 25. Location of simulated groundwater withdrawals by wells in the HA273UTchild model, Malad-Lower Bear River study area. 


\section{Rivers}

The smaller cell size of the child model, the analysis of previous data, and the collection and analysis of new data during this study provides the ability to simulate the Bear and Malad Rivers by using the River Package (Harbaugh, 2005, p. 6-6 to 6-12). This change from GBCAAS v. 1.0 allows for better resolution of the location and altitude of the rivers and more automated accounting of groundwater discharge to rivers than was possible in GBCAAS v. 1.0. The location of the rivers (fig. 26) was derived from the National Hydrography Dataset (U.S. Geological Survey, variously dated).

The simulated altitude of the rivers was determined to be the minimum of the river altitude in each cell or the altitude of the center of the grid as determined from the National Elevation Dataset (NED; U.S. Geological Survey EROS Data Center, 1999). The River Package calculates recharge and discharge through river cells as the product of riverbed conductance times the head difference between the river elevation and the simulated head in each cell (Harbaugh, 2005, eq. 6-5). Riverbed conductance is a function of the hydraulic conductivity of the riverbed material, the length of the river in each cell, the width of the river, and the thickness of the riverbed. In the HA273UTchild model, the length and width of the river in each cell is specified, and parameters define the hydraulic conductivity of the riverbed divided by the thickness of the riverbed. The Bear River is simulated as being $200 \mathrm{ft}$ wide and having a water-level stage $3 \mathrm{ft}$ above the bottom of the riverbed. The Malad River is simulated as being $30 \mathrm{ft}$ wide and having a water-level stage $2 \mathrm{ft}$ above the bottom of the riverbed. If simulated groundwater levels are above the stage of the river, flow from the groundwater system to the river is simulated. If simulated groundwater levels are below the stage of the river, flow from the river to the groundwater system is simulated.

\section{Springs}

Discharge to springs (figs. 26 and 27, tables A3-3 and A3-4) is simulated from multiple layers by using the Drain Package (Harbaugh, 2005, p. 6-12). The boundary conditions in GBCAAS v. 1.0 were changed to the boundary conditions in the HA273UTchild model by locating the spring at the correct child cell and changing the simulated altitude of the spring to reflect the more detailed land surface available for the child cell. More individual springs were simulated (table A3-6) than in the GBCAAS v. 1.0 model because (1) data were found detailing previous measurements that were not previously in the USGS National Water Information System (NWIS; Mathey, 1998) database, (2) new measurements were made, and (3) smaller springs are simulated because of the smaller cell size and more refined groundwater budget in the study area. Springs measured by the USGS with discharge greater than $10,000 \mathrm{ft}^{3} / \mathrm{d}$ and municipal springs reported to the State of Utah (table A3-4) with discharge greater than $20,000 \mathrm{ft}^{3} / \mathrm{d}$ are simulated. Large seeps without definite point locations are defined as area springs (fig. 27). More area springs are simulated in the child model than in the GBCAAS v. 1.0 model, mostly because the large discharge areas (table 6 , fig. 14) that were simulated as ETg in GBCAAS v. 1.0 were found during this study to consist more of diffuse groundwater discharge that is then used by vegetation than of groundwater use directly by vegetation.

The altitude of point springs was initially set at the altitude in the NWIS database or $10 \mathrm{ft}$ below the altitude at the center of the model cell as determined from NED, whichever is lowest. The altitude for area springs was set at $5 \mathrm{ft}$ below the altitude at the center of the cell or the lowest point of the spring area in the cell, whichever is lowest. Area springs typically occur in flat areas where the NED is likely to be accurate and the spring is not as incised as point springs. The conductance of drains representing springs is defined as parameters in the groundwater flow model. Drain conductance is defined by the conductance factor multiplied by the parameter value. The conductance factor for all point springs in GBCAAS v. 1.0 and the GBCAASv2parent model is one-tenth of the GBCAAS v. 1.0 model cell area, which is 250 percent of the HA273UTchild cell area. To prevent point springs having an assigned area larger than the child model cell area, the conductance factor in the HA273UTchild model was reduced to 100 percent of the child cell area. The parameter value (leakance, in /d) for point springs in the HA273UTchild model is defined as 2.5 times the parameter value for point springs in the GBCAASv2parent model. These changes create equal drain conductance for point springs in both models for consistent representation of springs. The conductance factor for area springs is the area of the spring in each cell. All springs are simulated in layer 1; drain boundaries were added to deeper layers as needed to achieve a closer match to observed spring discharge. Large springs typically required drain boundaries in multiple model layers to match observed spring discharge.

\section{Field Drains}

Field drains (fig. 27) were added to the model by using the Drain Package (Harbaugh, 2005, p. 6-12). In the Drain Package, the simulated discharge is calculated as the drain conductance multiplied by the difference in altitude between the simulated head and the drain; the drain conductance is defined by parameters in this model. The altitude of the drains was assigned as $5 \mathrm{ft}$ below land surface as defined by NED. Every cell containing field drains (fig. 27) was simulated as a drain boundary; the conductance factor is the length of field drains in each cell. The simulated conductance is the conductance factor multiplied by the drain parameter.

\section{Evapotranspiration from Groundwater}

Evapotranspiration of groundwater is simulated from layer 1 (fig. 27) by using the Drain Package (Harbaugh, 2005, p. 6-12). The Evapotranspiration Package (Harbaugh, 2005, p. 6-16) was not used in GBCAAS v. 1.0 because of numerical instability at the break in the discharge curve (Harbaugh, 2005, fig. 6-13), and is not used in the HA273UTchild model 


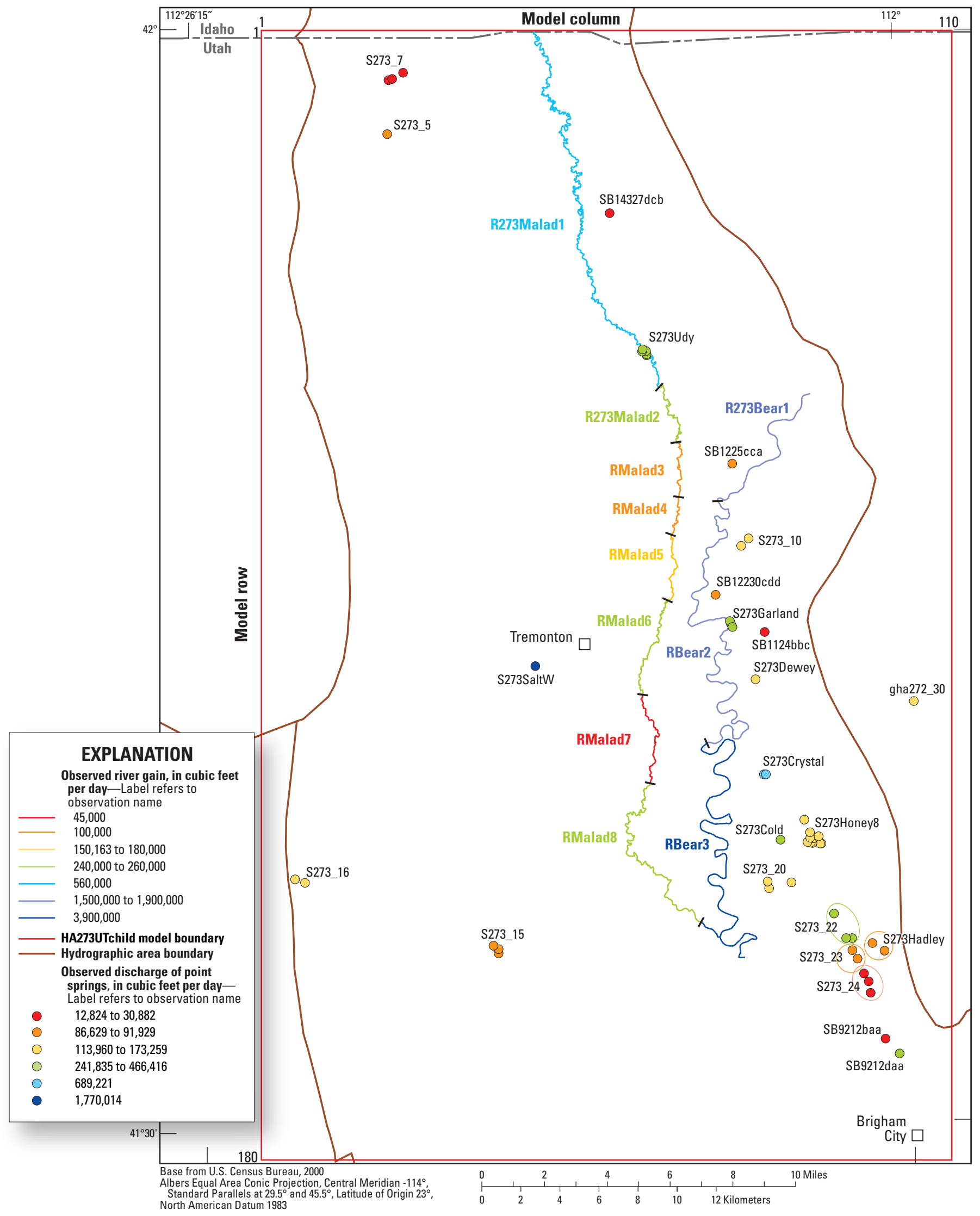

Figure 26. Conceptual discharge to springs and rivers simulated in the HA273UTchild model, Malad-Lower Bear River study area. 


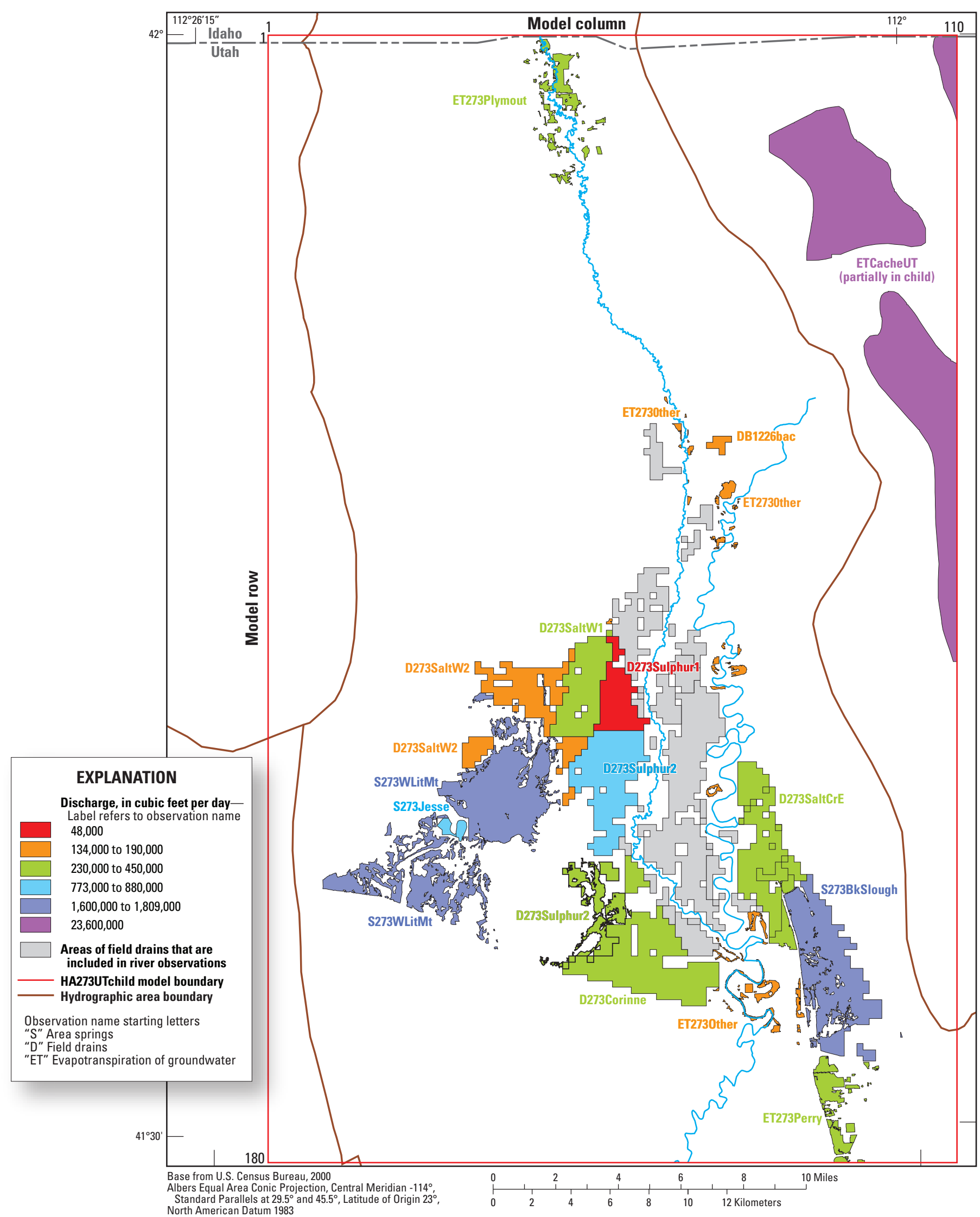

Figure 27. Conceptual discharge to area springs, field drains, and evapotranspiration in the HA273UTchild model, Malad-Lower Bear River study area. 
for consistency with the GBCAASv2parent model. Required information to simulate ETg in this model is the rate of ETg, the extinction depth (drain altitude), and the depth below land surface at which the observed ETg is presumed to occur (fig. 28). Only the portion of a cell in the ETg area is included in the calculation. Cells with less than 4 percent of the cell area in ETg areas were not included as ETg drain cells in the model. This method of simulating ETg allows ETg to vary linearly from the conceptual rate to zero when the simulated hydraulic head is from 0 to $5 \mathrm{ft}$ below land surface, which is similar to the Evapotranspiration Package (Harbaugh, 2005, fig. 6-13). The Drain Package does not limit the maximum rate of discharge (Harbaugh, 2005, fig. 6-10), so defining ETg as drains in this model allows ETg to be higher than the conceptual rate when simulated heads are above land surface. To eliminate the instability that can occur from multiple head-dependent boundaries in one cell, ETg is not simulated in areas with simulated rivers, springs, or field drains. Drain conductance is defined as parameters in this model; the ETg parameters are multipliers of the initial drain conductance.

The head-dependent boundaries representing ETg in the HA273UTchild model within the study area were changed extensively from GBCAAS v. 1.0 because (1) the refined cell size allowed for more accurate location and altitude, (2) analysis of data yielded refined areas where ETg occurs and refined rates of ETg (fig. 28 and "Evapotranspiration" section of this report), and (3) local grass vegetation has a shallower rooting depth than the assumed rooting depth of the shrub vegetation in GBCAAS v. 1.0.

In GBCAAS v. 1.0, it was assumed that the observed ETg occurs when the average water level is $5 \mathrm{ft}$ below land surface, and that the extinction depth is $40 \mathrm{ft}$ (Brooks and others, 2014, p. 27). In the portion of the HA273UTchild model within the study area, it was assumed that the observed ETg occurs when the average water level is at land surface, and that the extinction depth is $5 \mathrm{ft}$. The changes were made because most of the vegetation using groundwater in the study area consists of

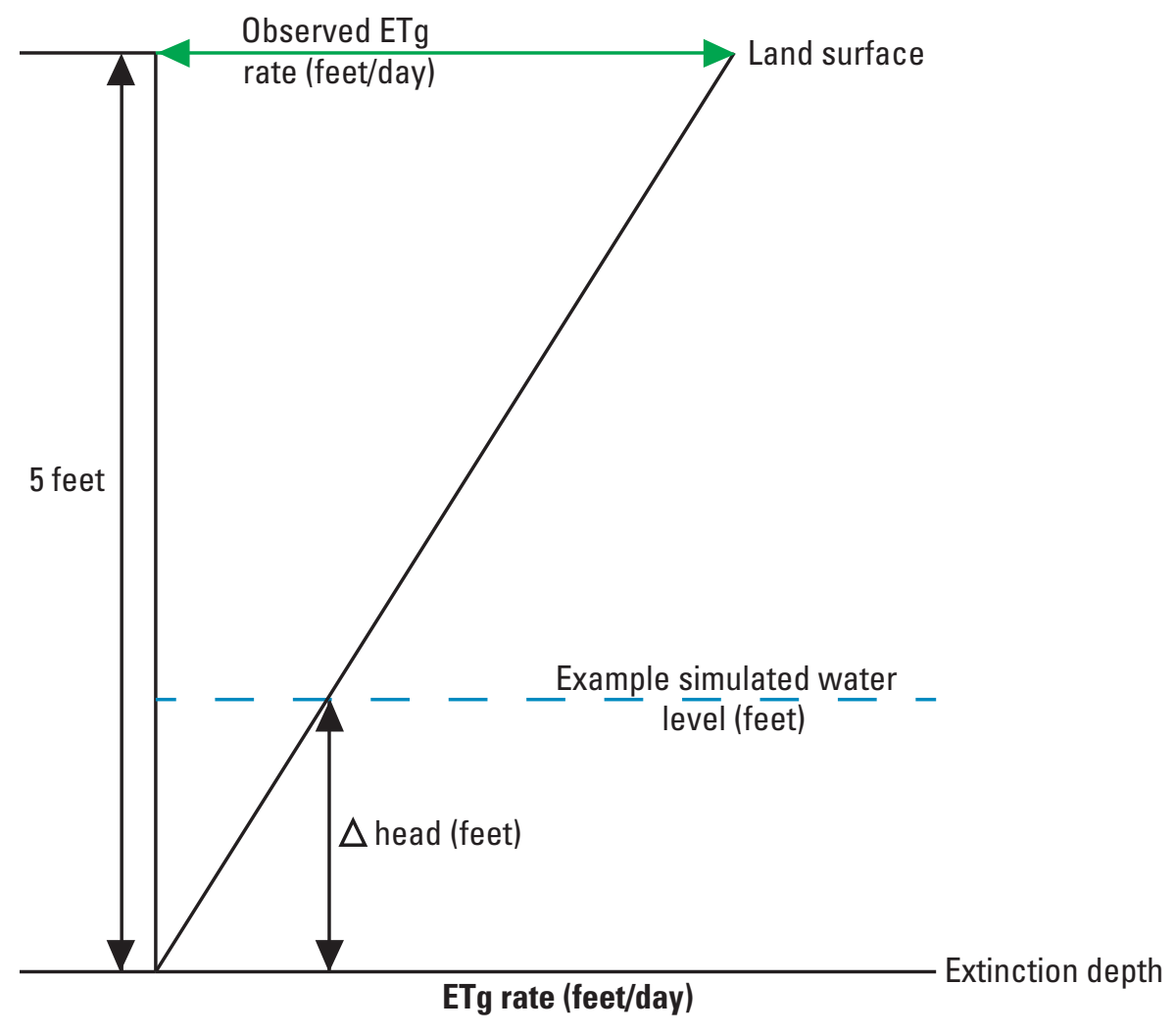

ETg is evapotranspiration of groundwater Leakance $(1 /$ day $)=$ Observed ETg rate $\div 5$ feet Cell conductance factor $\left(\right.$ feet ${ }^{2} /$ day; CF) $=$ Leakance $\times$ area $\left(\right.$ feet $\left.^{2}\right)$ of $E T g$ area in cell Parameter is a dimensionless multiplier of the $\mathrm{CF}$ Simulated ETg $($ feet $3 /$ day $)=$ Parameter $\times \mathrm{CF} \times \Delta$ head

Figure 28. Calculation of drain conductance used to simulate evapotranspiration of groundwater in the HA273UTchild model, MaladLower Bear River study area. 
grasses; grasses tend to use shallower sources of groundwater than woody species (Goedhart and Pataki, 2011, p. 464). Goedhart and Pataki (2011, fig. 5) show that the canopy cover of grasses is highest when groundwater is within about $1 \mathrm{ft}$ of land surface and decreases rapidly with groundwater depth from about 3 to $6.5 \mathrm{ft}$.

The simulation of ETg was not changed from GBCAAS v. 1.0 outside of the Malad-Lower Bear River Area (HA 273), even within the HA273UTchild model in Cache Valley (HA 272). During this study, it was estimated that all of the ET in the area south of Highway 83 and west of Interstate 15 is supplied by surface water, not groundwater (see "Groundwater Budget" section of this report). As a result, all ETg in this area was deleted in the HA273UTchild and GBCAASv2parent models within the study area.

\section{Hydraulic Properties}

Six of the nine hydrogeologic units (HGUs) described in Sweetkind and others (2011) are the basis for assigning horizontal hydraulic conductivity and vertical anisotropy to the model layers. The volcanic unit (VU), the thrusted lower carbonate aquifer unit (TLCAU), and the thrusted non-carbonate aquifer unit (TNCCU) do not exist within the HA273UTchild model. The HGUs are simulated by using the HydrogeologicUnit Flow (HUF) Package (Anderman and Hill, 2000; 2003) of MODFLOW-2005, which can represent the complexities of the geology (fig. 23). Hydrogeologic structures that act as barriers to groundwater flow are simulated by using the Horizontal-Flow Barrier (HFB) Package (Harbaugh, 2005, p. 5-21 to 5-22).

\section{Hydrogeologic Units}

The HUF Package takes as input the tops and thicknesses of each HGU and allows the hydraulic conductivity and vertical anisotropy of the HGUs to be defined through zones and parameters. The tops of the HGUs (Cederberg and others, 2011) were modified for consistency with the refined land surface and are used as the tops of the HUF units in the model; thickness of a HUF unit was defined as the top of the HGU minus the top of the next lower HGU. Because the geologic framework was developed using a 1-mi ${ }^{2}$ grid cell (Cederberg and others, 2011, p. 127), adjustments were necessary in the HA273UTchild model to ensure the geology was defined everywhere up to the refined land surface. These adjustments were made by assigning the land surface as the top of the UBFAU, and keeping the thickness of the units the same as in the geologic framework by moving the tops of the lower layers up or down. In this way, only the thickness of the NCCU (deepest HGU) differs from the framework or from GBCAAS v. 1.0, and the units exist in the same locations. Horizontal hydraulic conductivity and vertical anisotropy (the ratio of horizontal to vertical hydraulic conductivity) is defined for each HGU by using the HUF Package, parameters, and zones.
The HUF Package determines the hydrogeologic units that apply to each model cell (Anderman and Hill, 2000, fig. 1C). Although some model cells are filled by a single HGU, other model cells contain multiple HGUs. The HUF Package calculates the effective hydraulic conductivity in both the vertical and horizontal directions for each cell (Anderman and Hill, 2000, p. 7).

\section{Structures Simulated as Barriers}

Faults can create barriers to groundwater flow by juxtaposition of low-permeability materials and relatively highpermeability materials, and by low-permeability material (fault gouge) in the fault zone itself, which forms a barrier to flow across the fault (Caine and others, 1996). Juxtaposition is represented in the flow model by the geometry of the hydrogeologic framework (Cederberg and others, 2011). Faults, or portions of faults, that appear to create an additional barrier to flow are simulated by using the HFB Package (Harbaugh, 2005 , p. 5-21 to 5-22) of MODFLOW-2005. These flow barriers (fig. 29) were located along cell boundaries to approximate the location of selected major faults (Sweetkind and others, 2011, fig. B-8). HFBs are simulated in all model layers in some locations or in model layers 2 through 8 in areas where they were removed from layer 1 to prevent simulated water levels from being above land surface on the upgradient side of the barrier. The model input required for the HFB Package is the hydraulic characteristic of the barrier, which is the hydraulic conductivity of the barrier divided by the width of the barrier. It is assumed in this model that the width is $1 \mathrm{ft}$. The hydraulic characteristic is defined using parameters.

\section{Observations Used in Model Calibration}

The term "observation" is used to denote that model output is compared to a measured value of water level or discharge, and that the comparison is part of calibration, sensitivity analyses, and parameter estimation. Model observations used in GBCAAS v. 2.0 are groundwater levels at wells and discharge locations, and discharge to springs, evapotranspiration, rivers, lakes, and field drains (table 10). All observations used in the model are considered representative of steady-state conditions. For each observation, uncertainty was determined as part of model input. Uncertainties were expressed as standard deviation, variance, or coefficient of variation, and were converted to variance, which UCODE 2005 (Poeter and others, 2008) uses to define weights ( 1 divided by the variance). Weights are applied to the observations for calibration statistics, sensitivity analyses, and parameter estimation.

\section{Water Levels in Wells}

The water levels used for observations in GBCAAS v. 1.0 are documented in Brooks and others (2014). During this study, it was determined that two water levels used for 


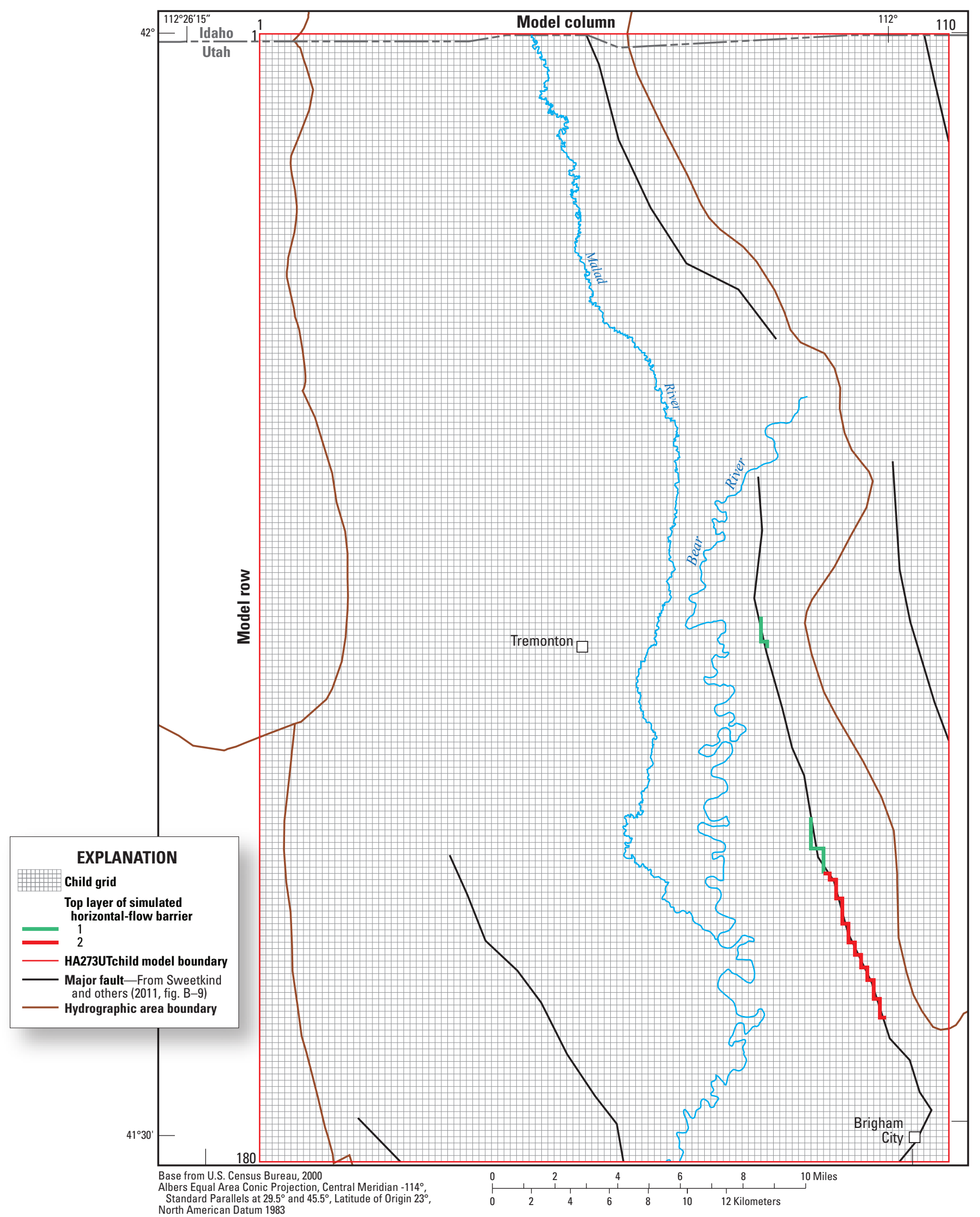

Figure 29. Horizontal-flow barriers representing selected faults in the HA273UTchild model, Malad-Lower Bear River study area. 
Table 10. Summary statistics of observations in the GBCAAS v. 2.0 groundwater model, Great Basin carbonate and alluvial aquifer system study area.

[All water-level observations in feet. All discharge observations in cubic feet per day. Average standard deviation in feet squared. Weights of discharge observations were increased for calibration, and average weighted coefficient of variation is value used in model regression and fit statistics. -, not applicable]

\begin{tabular}{|c|c|c|c|c|c|c|c|}
\hline Type of observation & $\begin{array}{c}\text { Number of } \\
\text { observations }\end{array}$ & $\begin{array}{c}\text { Minimum } \\
\text { observation }\end{array}$ & $\begin{array}{c}\text { Maximum } \\
\text { observation }\end{array}$ & $\begin{array}{c}\text { Average } \\
\text { observation }\end{array}$ & $\begin{array}{l}\text { Average } \\
\text { standard } \\
\text { deviation }\end{array}$ & $\begin{array}{l}\text { Average } \\
\text { coefficient of } \\
\text { variation }\end{array}$ & $\begin{array}{c}\text { Average } \\
\text { weighted } \\
\text { coefficient of } \\
\text { variation }\end{array}$ \\
\hline \multicolumn{8}{|c|}{ Water levels in HA273UTchild model } \\
\hline Water levels in wells & 50 & 4,221 & 5,062 & 4,419 & 27.9 & - & - \\
\hline River altitudes & 0 & - & - & - & - & - & - \\
\hline Spring altitudes & 9 & 4,300 & 5,448 & 4,929 & 31.6 & - & - \\
\hline Total or weighted average & 59 & 4,221 & 5,448 & 4,497 & 28.5 & - & - \\
\hline \multicolumn{8}{|c|}{ Discharge ${ }^{1}$ in HA273UTchild model } \\
\hline Spring and field drain discharge & 35 & $-12,824$ & $-1,800,000$ & $-339,659$ & - & 0.38 & 0.17 \\
\hline Evapotranspiration & 3 & $-191,000$ & $-286,000$ & $-250,433$ & - & 0.45 & 0.20 \\
\hline River discharge $^{2}$ & 11 & $-90,000$ & $-4,900,000$ & $-1,043,000$ & - & 0.32 & 0.14 \\
\hline Lake discharge & 0 & - & - & - & - & - & - \\
\hline Total or weighted average & 49 & $-12,824$ & $-4,900,000$ & $-492,000$ & - & 0.37 & 0.17 \\
\hline \multicolumn{8}{|c|}{ Water levels in GBCAASv2parent model } \\
\hline Water levels in wells & 1,502 & -280 & 9,645 & 4,568 & 23.6 & - & - \\
\hline River altitudes & 33 & 4,897 & 8,632 & 6,731 & 31.6 & - & - \\
\hline Spring altitudes & 173 & 680 & 8,235 & 5,241 & 28.6 & - & - \\
\hline Total or weighted average & 1,708 & -280 & 9,645 & 4,678 & 24.3 & - & - \\
\hline \multicolumn{8}{|c|}{ Discharge ${ }^{1}$ in GBCAASv2parent model } \\
\hline Spring discharge & 152 & $-46,282$ & $-4,367,281$ & $-539,318$ & - & 0.26 & 0.12 \\
\hline Evapotranspiration ${ }^{3}$ & 96 & $-51,282$ & $-18,666,076$ & $-2,974,191$ & - & 0.30 & 0.13 \\
\hline River discharge $e^{4}$ & 53 & $-57,813$ & $-20,274,333$ & $-1,537,186$ & - & 0.24 & 0.11 \\
\hline Lake discharge & 5 & $-143,000$ & $-6,797,864$ & $-2,652,313$ & - & 0.30 & 0.13 \\
\hline Total or weighted average & 306 & $-46,282$ & $-20,274,333$ & $-1,510,559$ & - & 0.27 & 0.12 \\
\hline
\end{tabular}

\footnotetext{
${ }^{1}$ Discharge is considered negative in MODFLOW. A larger discharge, therefore, is a more negative number.

${ }^{2}$ Three are only river observations; eight are derived observations of rivers and drains to rivers. The lower reach of Bear River is simulated, but is not a model observation.

${ }^{3}$ One evapotranspiration observation is a derived observation including the parent and child models. Most of the discharge is in the parent model.

${ }^{4}$ Fifty-six river observations are used in MODFLOW-LGR for budget accounting, but the amount of groundwater discharge to three of the rivers is not known, and they are not used as UCODE observations for calibration.
}

calibration of the GBCAAS v. 1.0 model in the area defined by the HA273UTchild model could not be verified and they were removed from the model (table A3-1). Because data collected during this study indicated that the groundwater system in the study area can be considered to be in steady-state conditions, more water levels were added as observations. These included 24 observations in the HA273UTchild model and 1 observation in the GBCAASv2parent model (table A3-1).

Water levels at 50 wells in the HA273UTchild model (fig. 30, table A3-1) and 1,502 wells in the GBCAASv2parent model (table A3-1; Brooks and others, 2014, fig. 19 and pl. 1) are defined as steady-state water-level observations. The calibration target at each well is the average water level over the time period for which water-level measurements in the well were used. Decadal and seasonal fluctuations were treated as noise in the observations and are accounted for through an analysis of observation errors. Wells were used as observations only if their land-surface altitude and depth were known. The open intervals of wells were used to determine the model layers associated with the observations. For wells open to more than one model layer, simulated heads are a weighted average calculated by the MODFLOW-2005 Head Observation Package (HOB) on the basis of the length of opening in each layer (Harbaugh and Hill, 2009, p. 5). Most of the wells have open intervals and completion depths in the upper model layers (fig. 30; Brooks and others, 2014, table 5 and fig. 19). Uncertainty associated with water levels in wells is explained in Brooks and others (2014) and San Juan and others (2004). The methods used to determine uncertainty in this groundwater flow model are the same as used to determine uncertainty in GBCAAS v. 1.0 (Brooks and others, 2014, appendix 2) and are not repeated in this report.

\section{Water Levels at Discharge Locations}

Water levels at selected spring locations are used as observations to provide sensitivity to parameters if the simulated discharge is zero. If a head-dependent discharge boundary is not discharging water, changing parameter values does not cause the discharge to change and sensitivity to the parameter 


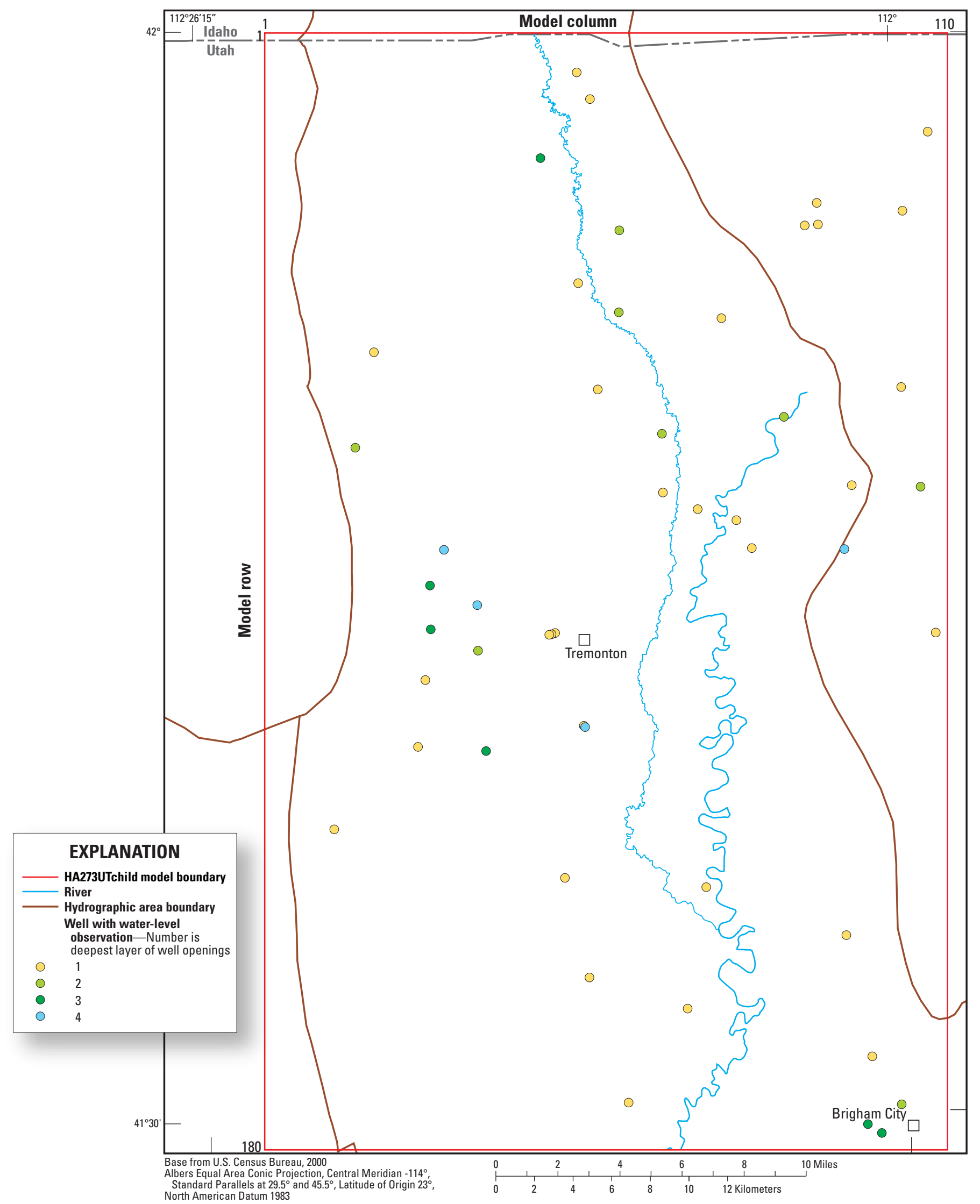

Figure 30. Model-layer distribution of water-level observations at wells used in the HA273UTchild model, Malad-Lower Bear River study area. 
is zero. Water levels at these locations, however, do have sensitivity to model parameters. Water levels at springs also are used as observations if the spring altitude was lowered in the Drain Package to allow discharge to be simulated. The altitude used for water-level observations at springs is the spring altitude reported in the NWIS database (Mathey, 1998), but a minimum of $10 \mathrm{ft}$ below the altitude of land surface at the center of the grid cell or the spring point as determined from the NED. The variance assigned to the altitude of discharge points was $1,000 \mathrm{ft}^{2}$, which is similar to variances in water levels at wells (table A3-1).

\section{Groundwater Discharge and Uncertainty}

Groundwater discharge observations in GBCAAS v. 2.0 include discharge to springs and field drains, ETg, rivers, and lakes. Discharge is considered negative in MODFLOW, and all discharge observations are reported as negative in this report to match model files. A larger discharge, therefore, is a more negative number. The amount of discharge used for each observation and the uncertainty of these observations for the GBCAASv2parent model are documented in Brooks and others (2014). In general, discharge data have larger uncertainty than water-level data, largely because of measurement error and because of seasonal or annual changes that are not measured by what are often only one-time measurements or estimates. The discharge observations for the HA273UTchild model, which do not include lakes, are discussed in the following sections.

\section{Rivers}

Groundwater discharge to the Bear and Malad Rivers (table A3-2) was determined as explained in the "Discharge" section of this report. The coefficients of variation for the observations were determined by the accuracy of the measurements during seepage runs as part of this study (table A2-2). Many sections of the rivers have field drains that enter them. The discharge from these drains is assumed to be part of the measured gain in the rivers, and the model observations are the summation of flow from the drains and gain or loss in the river segments.

\section{Springs}

Discharge observations for springs in the HA273UTchild model (tables A3-3 and A3-4) were developed from discharge data collected during this study, the NWIS database, Bjorklund and McGreevy $(1973,1974)$, and the Utah Division of Water Rights (2014). For springs with more than one measurement, the repeated measurements were used to calculate variance and coefficient of variation. The average coefficient of variation of the discharge at these springs was 0.45 ; this coefficient of variation is assumed to apply to all springs with only one discharge measurement.
Multiple springs were sometimes combined into one observation (tables A3-3 and A3-4) because they are located in the same model cell or they are located near other springs, and at the scale of this model, minor variations of discharge in nearby cells is not as important as the total discharge in an area. When springs were combined, the variances were added to determine the new variance; the coefficients of variation, therefore, do not equal the original coefficients of variation.

\section{Field Drains}

Only three measurements of discharge from field drains are available (observations D273Sulphur1 and D273SaltW1; tables A3-2 and A3-3, fig. 27). Discharge from other areas of field drains are included with discharge in one of the major discharge areas (fig. 14), discharge to one of the rivers, or was estimated (observation D273SaltW2, table A3-3). Because measurements were made only once or the discharge was estimated, the coefficient of variation for each of the observations is 0.45 .

\section{Evapotranspiration from Groundwater}

Discharge observations for ETg in the HA273UTchild model (table A3-3) were developed from data in table 8. In four major discharge areas (tables 6 and 8, fig. 14), it is difficult to separate ETg from groundwater discharge to field drains or to diffuse seepage. In these areas, the spring, drain, or ETg observation includes all forms of discharge. For simplification, ETg also was assumed to have a coefficient of variation of 0.45 for all ETg observations in the HA273UTchild model.

\section{Calibration}

The original scope of this study included using the existing GBCAAS v. 1.0 model with the addition of a refined model in the study area by using MODFLOW-LGR, but without additional calibration. During the course of this study, however, data were collected that caused several model boundary conditions to change more than anticipated, and calibration was performed to adjust the model to the more realistic boundary conditions. These major changes in boundary conditions are as follows: (1) recharge from irrigation is less and is distributed differently than in GBCAAS v. 1.0, (2) field drains are added to the model, (3) groundwater discharge to the rivers is distributed to each river and to each reach along the rivers, and (4) evapotranspiration of groundwater is much less and is concentrated in smaller areas.

The purpose of the model calibration for this study was to develop a model that reasonably represents groundwater recharge, movement, and discharge within the study area. During calibration, model parameters were changed to adjust the value and distribution of recharge, horizontal hydraulic conductivity, vertical anisotropy, river conductance, and the location of horizontal-flow barriers. Because of the use 
of this model to develop maps showing the effects of projected withdrawals, the emphasis of calibration was to match discharge to rivers and major springs (discharge greater than 1,000 acre-ft/yr; $119,000 \mathrm{ft}^{3} / \mathrm{d}$ ) to within 30 percent of the observed discharge. Another purpose of calibration was to limit changes to the simulated values at observations in the GBCAASv2parent model outside of the study area; this required some adjustment of parameters in the GBCAASv2parent model in response to the different boundary conditions in the HA273UTchild model.

\section{Method}

For the calibration of GBCAAS v. 2.0, an abbreviated version of the calibration methods described for GBCAAS v. 1.0 was used; more details are provided in Brooks and others (2014). In general, nonlinear regression was used only to guide selection of parameter values, composite scaled sensitivities were used to guide separation and combination of parameters, and influence statistics were used to guide parameter zonation. Composite scaled sensitivities reflect the amount of information provided by the observations for the estimation of each parameter (Hill and Tiedeman, 2007, p. 50). During calibration, the regressed values of parameters were compared to reasonable values. Unrealistic estimated parameter values can indicate model error (Hill and Tiedeman, 2007, p. 80) and were used to guide model changes and calibration. Reasonable parameter values in GBCAAS v. 2.0 are the same as in GBCAAS v. 1.0, with the addition of reasonable values for pumping in the HA273UTchild model (tables 11 and 12; Brooks and others, 2014, tables 3 and 6).
As with GBCAAS v. 1.0 (Brooks and others, 2014, p. 40), the weight of discharge observations was increased in comparison to water-level observations. This increased weighting is frequently done, especially for observations that provide unique information (Hill and Tiedeman, 2007, p. 301). In groundwater systems, discharge data provide information that reduces correlation among parameters (Hill and Tiedeman, 2007, p. 302). All discharge observations were given a weight multiplier of 5.0 as in GBCAAS v. 1.0. During calibration, spring altitude at selected point springs was lowered by as much as $200 \mathrm{ft}$ in an attempt to simulate observed discharge. Sixteen percent ( 9 out of 56) of the drain cells representing point springs had the altitude adjusted, but only two percent ( 1 out of 56) had the altitude adjusted as much as $200 \mathrm{ft}$. Altitude adjustment was not made at area springs.

During model calibration, the simulated water level in layer 1 was frequently compared to land-surface altitude to ensure that abnormally high simulated water levels were not occurring. These comparisons are not formal observations, but parameter values or zones were modified if they created areas of water levels more than $50 \mathrm{ft}$ above land surface.

Some model parameters were divided and refined in this model even though the composite scaled sensitivities are not high. This achieved a better match between simulated and observed discharge in some locations. Because model observations provide little information about insensitive parameters, it is difficult to assess how well they are estimated in the simulation. Many of the parameters with the lowest composite scaled sensitivities are HFB parameters, which have a low conductance value, or hydraulic-conductivity parameters that have a low hydraulic-conductivity value. Hill and Tiedeman (2007, p. 43) state that measures of importance (including sensitivity)

Table 11. Horizontal hydraulic-conductivity estimates of hydrogeologic units in the Death Valley regional groundwater flow system and the Great Basin carbonate and alluvial aquifer system study area.

[Modified from Belcher and others, 2002, table 1 and Brooks and others, 2014, table 3. Geometric mean and standard deviation are back-transformed from logarithmic values. Abbreviations: GBCAAS, Great Basin carbonate and alluvial aquifer system; DVRFS, Death Valley regional groundwater flow system. Hydrogeologic unit acronyms for Great Basin carbonate and alluvial aquifer system: UBFAU, upper basin-fill aquifer unit; LBFAU, lower basin-fill aquifer unit; VU, volcanic unit; UCAU, upper carbonate aquifer unit; LCAU, lower carbonate aquifer unit; TLCAU, thrusted lower carbonate aquifer unit; USCU, upper siliciclastic confining unit; NCCU, non-carbonate confining unit; TNCCU, thrusted non-carbonate confining unit. Hydrogeologic unit acronyms for Death Valley regional groundwater flow system: AA, alluvial aquifer; ACU, alluvial confining unit; YVU, younger volcanic rocks unit; VSU, volcaniclastic and sedimentary rocks unit; TV, Tertiary volcanic rocks; OVU, older volcanic rocks unit; UCA, upper carbonate aquifer; LCA, lower carbonate aquifer; UCCU, upper clastic confining unit; LCCU, lower clastic confining unit]

\begin{tabular}{|c|c|c|c|c|c|c|c|c|c|}
\hline \multirow{3}{*}{ GBCAAS hydrogeologic unit } & \multirow{3}{*}{$\begin{array}{c}\text { DVRFS } \\
\text { hydrogeologic } \\
\text { unit or subunit }\end{array}$} & \multicolumn{8}{|c|}{ Hydraulic conductivity (feet per day) } \\
\hline & & \multirow[t]{2}{*}{$\begin{array}{l}\text { Geometric } \\
\text { mean }\end{array}$} & \multirow[t]{2}{*}{$\begin{array}{l}\text { Arithmetic } \\
\text { mean }\end{array}$} & \multirow[t]{2}{*}{ Minimum } & \multirow[t]{2}{*}{ Maximum } & \multicolumn{2}{|c|}{$\begin{array}{l}\text { 95-percent confidence interval } \\
\text { (reasonable range) }\end{array}$} & \multirow[t]{2}{*}{$\begin{array}{l}\text { Number of } \\
\text { measurements }\end{array}$} & \multirow[t]{2}{*}{$\begin{array}{r}\text { Standard } \\
\text { deviation o } \\
\text { log values }\end{array}$} \\
\hline & & & & & & Low & High & & \\
\hline UBFAU, non-playa & AA & 4.9 & 35 & 0.0002 & 430 & 0.02 & 1,400 & 52 & 1.3 \\
\hline UBFAU, playa & $\mathrm{ACU}$ & 9.8 & 34 & 0.01 & 110 & 0.07 & 1,500 & 15 & 1.1 \\
\hline LBFAU & YVU/VSU & 0.2 & 4.9 & 0.0001 & 20 & 0.0002 & 260 & 15 & 1.6 \\
\hline UCAU, LCAU, and TLCAU & $\begin{array}{l}\text { UCA and } \\
\text { LCA }\end{array}$ & 8.2 & 300 & 0.0003 & 2,700 & 0.003 & 25,000 & 53 & 1.8 \\
\hline USCU, NCCU, and TNCCU & $\begin{array}{l}\text { UCCU and } \\
\text { LCCU }\end{array}$ & 0.00007 & 0.7 & 1.E-07 & 16 & 3. $\mathrm{E}-10$ & 9.8 & 29 & 2.7 \\
\hline
\end{tabular}


Table 12. Estimates of properties describing parameter values for recharge, drains, rivers, horizontal-flow barriers, vertical anisotropy, and wells in the GBCAAS v. 2.0 groundwater model, Great Basin carbonate and alluvial aquifer system study area.

[Modified from Brooks and others, 2014, table 6. Abbreviations: ETg, evapotranspiration from groundwater; —, not applicable]

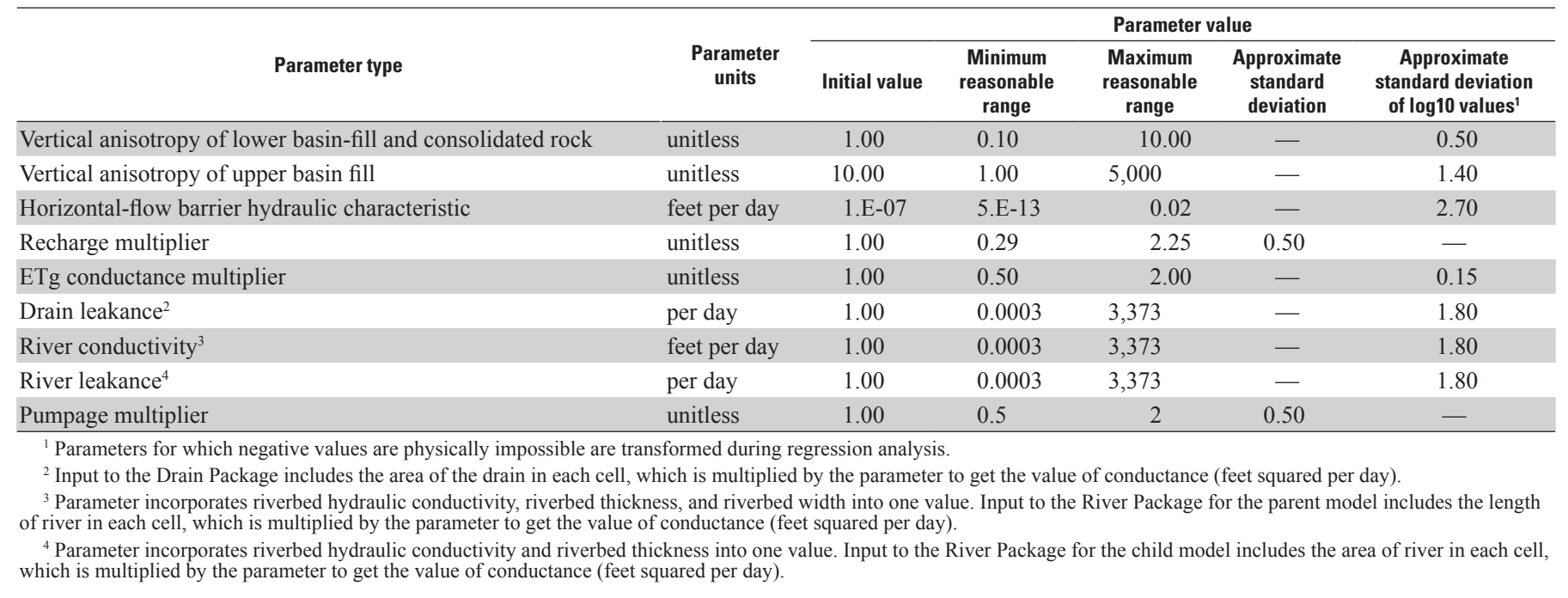

of the value of parameters with extremely small values of conductivity will tend to be small.

For final analysis of sensitivity, parameter correlation, parameter confidence intervals, and prediction uncertainty, prior information is used for 10 parameters (table 13) that cannot be estimated by the model with a standard deviation lower than the observed standard deviation listed in tables 11 and 12. Prior information is used to simulate a realistic degree of uncertainty in these 10 parameters (Hill and Tiedeman, 2007, p. 131). Seven of these parameters also required prior information in GBCAAS v. 1.0, including parameter rch275 in and near the HA273UTchild model. Two new recharge parameters (rchrun2721 and rchrun2722) that represent recharge in limited areas require prior information. They were introduced in GBCAAS v. 2.0 to allow the multiplier defining recharge from runoff to match more closely conceptual runoff, but allow total simulated recharge to match GBCAAS v. 1.0 simulated recharge. The third new parameter with prior information is pumpage, which defines the withdrawal from wells in the HA273UTchild model; withdrawals are a small part of the groundwater budget.

\section{Parameter Values in Calibrated Model}

During calibration of GBCAAS v. 2.0, most differences from GBCAAS v. 1.0 were in the representation of recharge, horizontal hydraulic conductivity, vertical anisotropy of the UBFAU, and riverbed conductance in the HA273UTchild model. Changes to parameters describing conductance of ETg and springs, and the representation of HFBs were not

Table 13. Prior-information statistics for selected parameters in the GBCAAS v. 2.0 groundwater model, Great Basin carbonate and alluvial aquifer system study area.

[Modified from Brooks and others, 2014, table 7. Prior value: unitless for well, recharge multiplier, and ETg conductance multiplier parameters; feet per day for hydraulic conductivity parameter. Standard deviation: of the value for recharge and well parameters, of the log of the value for hydraulic conductivity and evapotranspiration parameters. Abbreviations: HA, hydrographic area; ETg, evapotranspiration from groundwater]

\begin{tabular}{|c|c|c|c|c|}
\hline Parameter type & Parameter name & Prior value & Standard deviation & Location \\
\hline \multicolumn{5}{|c|}{ Parameter only in HA273UTchild model } \\
\hline Well & pumpage & 0.995 & 0.5 & HA 273 \\
\hline \multicolumn{5}{|c|}{ Parameters in HA273UTchild model and GBCAASv2parent model } \\
\hline Recharge multiplier & rchrun2721 & 66.5 & 0.5 & Small part of HA 272 \\
\hline Recharge multiplier & rchrun2722 & 24.1 & 0.5 & Small part of HA 272 \\
\hline Recharge multiplier & $\operatorname{rch} 275$ & 6.64 & 0.5 & HAs 275 and 276 , small part of HA 273 \\
\hline Recharge multiplier & rch9999 & 0.01 & 0.5 & Various locations \\
\hline \multicolumn{5}{|c|}{ Parameters only in GBCAASv2parent model } \\
\hline Recharge multiplier & $\operatorname{rch} 282$ & 1.82 & 0.5 & Part of HA 282 \\
\hline Hydraulic conductivity & ucau31hk & 0.0005 & 1.8 & Near Lake Mead \\
\hline ETg conductance multiplier & et265 & 1.5 & 0.15 & HAs 265 and 266 \\
\hline ETg conductance multiplier & et268 & 0.986 & 0.15 & HA 268 \\
\hline ETg conductance multiplier & et_sevier & 2.21 & 0.15 & HAs $259,285-287$ \\
\hline
\end{tabular}


as varied. Appendix 4 presents descriptions, statistics, and distributions of the model parameters. The final GBCAAS v. 2.0 model has 186 parameters; GBCAAS v. 1.0 had 176 parameters. GBCAAS v. 2.0 has 179 parameters that are used by the GBCAASv2parent model because two recharge parameters and one hydraulic-conductivity parameter were added to the GBCAASv2parent model to represent conditions near the HA273UTchild model. The recharge parameters are also in the HA273UTchild model. The child model has 37 parameters, 27 of which were in GBCAAS v. 1.0, and three of which were added to the GBCAASv2parent model and the HA273UTchild model. Only seven parameters are exclusively in the HA273UTchild model. The value of only one parameter in GBCAAS v. 1.0 was changed during the calibration of this model. The value of rch 275 was increased from 6.47 to 6.64. Values of other parameters in GBCAAS v. 1.0 were not changed in GBCAAS v. 2.0. Final parameter values are not optimized; further regression by UCODE_2005 changed the values, but did not necessarily improve model fit, or caused other problems such as larger areas of simulated water levels above land surface.
Final model parameters have little correlation, which indicates that the parameters can be determined independently of each other. No parameters have correlation coefficients exceeding 0.95 and only three pairs (rch117 and et_marshes, rch364 and NCCU11hk, and rch272 and LCAU612HK) have correlation coefficients exceeding 0.85 .

Composite scaled sensitivities (fig. 31) indicate the observations of discharge to rivers, springs, field drains, and ETg provide more information about the new model parameters than do water-level observations. Linear confidence intervals of parameters (fig. 32) indicate the simulated values provide enough information to constrain most of the new parameters to smaller ranges than the conceptual constraints, and that most of the new parameter values are within reasonable ranges (fig. 32, tables 11 and 12). Because the model is nonlinear, these confidence intervals are not exact, but the error cannot be quantified. Poeter and others (2008, p. 26) state that the 95-percent interval may in reality reflect a 99 - or 50-percent significance level. Christensen and Cooley (1999) state that nonlinear effects can cause the nonlinear intervals to be asymmetric and either larger or smaller than the linear approximations.

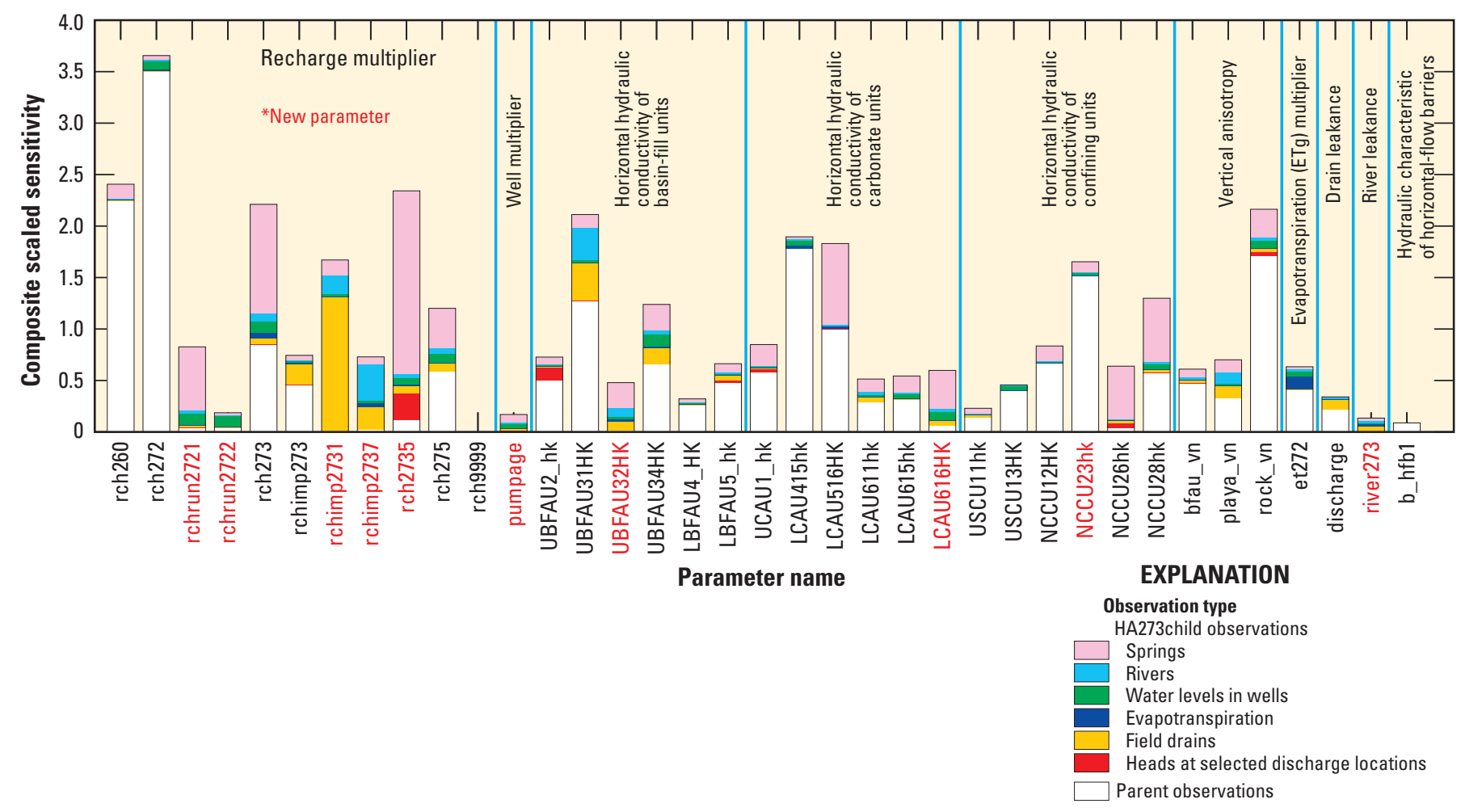

Figure 31. Composite scaled sensitivities for final parameters used in the HA273UTchild model, Malad-Lower Bear River study area. 


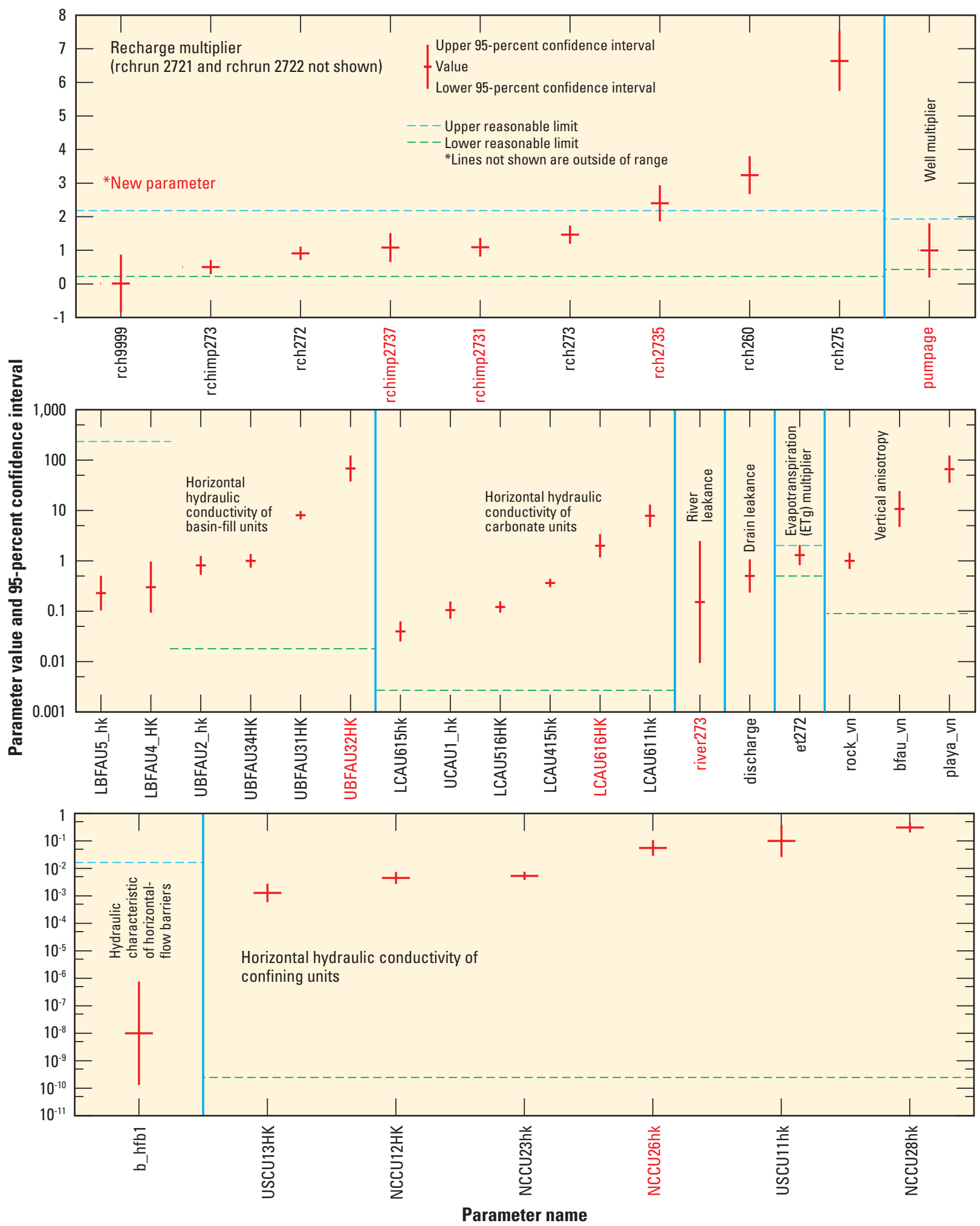

Figure 32. Values and linear confidence intervals of final parameters used in the HA273UTchild model, Malad-Lower Bear River study area. 


\section{Model Evaluation}

The model was evaluated to assess the likely accuracy of simulated results. As part of the model evaluation, the model fit to observations of water levels and discharge, and comparison of simulated to conceptual water budgets were evaluated. Results of this evaluation, as detailed in the following sections, indicate this model provides a reasonable representation of the groundwater system. This report discusses only the model evaluation of the HA273UTchild model; the discussion presented by Brooks and others (2014) closely approximates the statistics for GBCAAS v. 2.0.

\section{Model Fit to Observations}

Because of the intended use of this model for capture maps, the specific interest in the Malad River, and the limited project scope for calibration, calibration attempts were concentrated on reducing the unweighted residuals for large discharge observations to within 30 percent of the observations. Model fit to observations (table 14) is evaluated by using both unweighted and weighted residuals (the difference between observed and simulated values). Unweighted residuals have the same dimensions as the observations and are clearly understood, but they can be misleading because observations may be measured with different accuracy. Two unweighted residuals that are of equal value may not indicate an equally satisfactory model fit.

Weighted residuals are used in summary statistics (table 14) and regression. Weighted residuals are dimensionless quantities that reflect model fit in the context of the expected accuracy of the observations (Hill and Tiedeman,
2007, p. 35). A weighted residual of 2.0, for example, indicates that the unweighted residual is twice the observation error, where the error is defined as standard deviation. Weighted residuals are expected to be random and normally distributed (Hill and Tiedeman, 2007, p. 109). The correlation coefficient $\left(\mathrm{R}_{\mathrm{N}}^{2}\right)$ between the weighted residuals and the normal order statistics as calculated by UCODE_2005 for the HA273UTchild model is 0.801 . This is substantially less than the required 0.98 (Hill and Teideman, 2007, table D.3) and indicates the residuals are not normally distributed. Histograms of the residuals (fig. $33 A, B$ ), however, show that the distribution is skewed mostly by three discharge observations.

The square root of the sum of square weighted residuals (SOSWR; table 14) divided by the number of observations (Nobs) is called the standard error of the regression (Hill and Tiedeman, 2007, p. 95) and provides a measure of model fit relative to the weighting that can be compared for different types of observations. A value of 1.0 indicates a match that is, overall, consistent with the observation error evaluation used to determine the weighting (Hill and Tiedeman, 2007, p. 96). The standard error of the regression can be used to multiply the standard deviations and coefficients of variation of observations to obtain dimensional values that reflect the fit of any group of observations (Hill and Tiedeman, 2007, p. 95).

\section{Water-Level Observations}

The fit of simulated to observed water levels is generally adequate, especially as the project scope included only limited model calibration. The standard error of the regression of 2.74 for water levels in wells in the HA273UTchild model (table 14) multiplied by the average standard deviation

Table 14. Summary statistics for measures of model fit in the HA273UTchild model, Malad-Lower Bear River study area.

[Abbreviations: SOSWR, sum of squared weighted residuals; Nobs, number of observations; ETg, evapotranspiration from groundwater; - , not applicable]

\begin{tabular}{|c|c|c|c|c|c|c|c|c|}
\hline \multirow[b]{2}{*}{ Type of observation } & \multirow[b]{2}{*}{$\begin{array}{c}\text { Number of } \\
\text { observations }\end{array}$} & \multicolumn{2}{|c|}{ Unweighted residuals } & \multicolumn{5}{|c|}{ Weighted residuals } \\
\hline & & $\begin{array}{l}\text { Average } \\
\text { residual' }\end{array}$ & $\begin{array}{c}\text { Average residual } \\
\text { as percent of range } \\
\text { (for water levels) } \\
\text { or average (for } \\
\text { discharge) }\end{array}$ & $\begin{array}{l}\text { Average posi- } \\
\text { tive weighted } \\
\text { residual }\end{array}$ & $\begin{array}{l}\text { Average nega- } \\
\text { tive weighted } \\
\text { residual }\end{array}$ & $\begin{array}{l}\text { Average } \\
\text { weighted } \\
\text { residual }\end{array}$ & SOSWR & $\begin{array}{c}\text { Standard error } \\
\text { of regression, } \\
\text { (SOSWR/ } \\
\text { Nobs) })^{1 / 2}\end{array}$ \\
\hline \multicolumn{9}{|c|}{ Water levels ${ }^{2}$} \\
\hline Water levels in wells & 50 & 24 & 2.8 & 2.11 & -1.27 & 1.16 & 375 & 2.74 \\
\hline Spring altitudes ${ }^{3}$ & 9 & 177 & 15.4 & 5.60 & - & 5.60 & 523 & 7.62 \\
\hline Total or weighted average & 59 & 47 & 4.7 & 2.64 & - & 1.84 & 898 & 3.90 \\
\hline \multicolumn{9}{|c|}{ Discharge $^{4}$} \\
\hline Spring and drain discharge & 35 & $-22,482$ & 6.6 & 1.52 & -0.87 & 0.22 & 161 & 2.14 \\
\hline ETg discharge & 3 & 105,378 & -42.1 & 4.04 & -0.88 & 2.40 & 36 & 3.47 \\
\hline River discharge & 11 & $-110,807$ & 10.6 & 1.41 & -1.11 & -0.65 & 16 & 1.22 \\
\hline Total or weighted average & 49 & $-34,482$ & 4.5 & 1.65 & -0.92 & 0.16 & 213 & 2.09 \\
\hline \multicolumn{9}{|c|}{ All observations } \\
\hline Total or weighted average & 108 & - & - & 2.19 & - & 1.08 & 1,111 & 3.21 \\
\hline
\end{tabular}



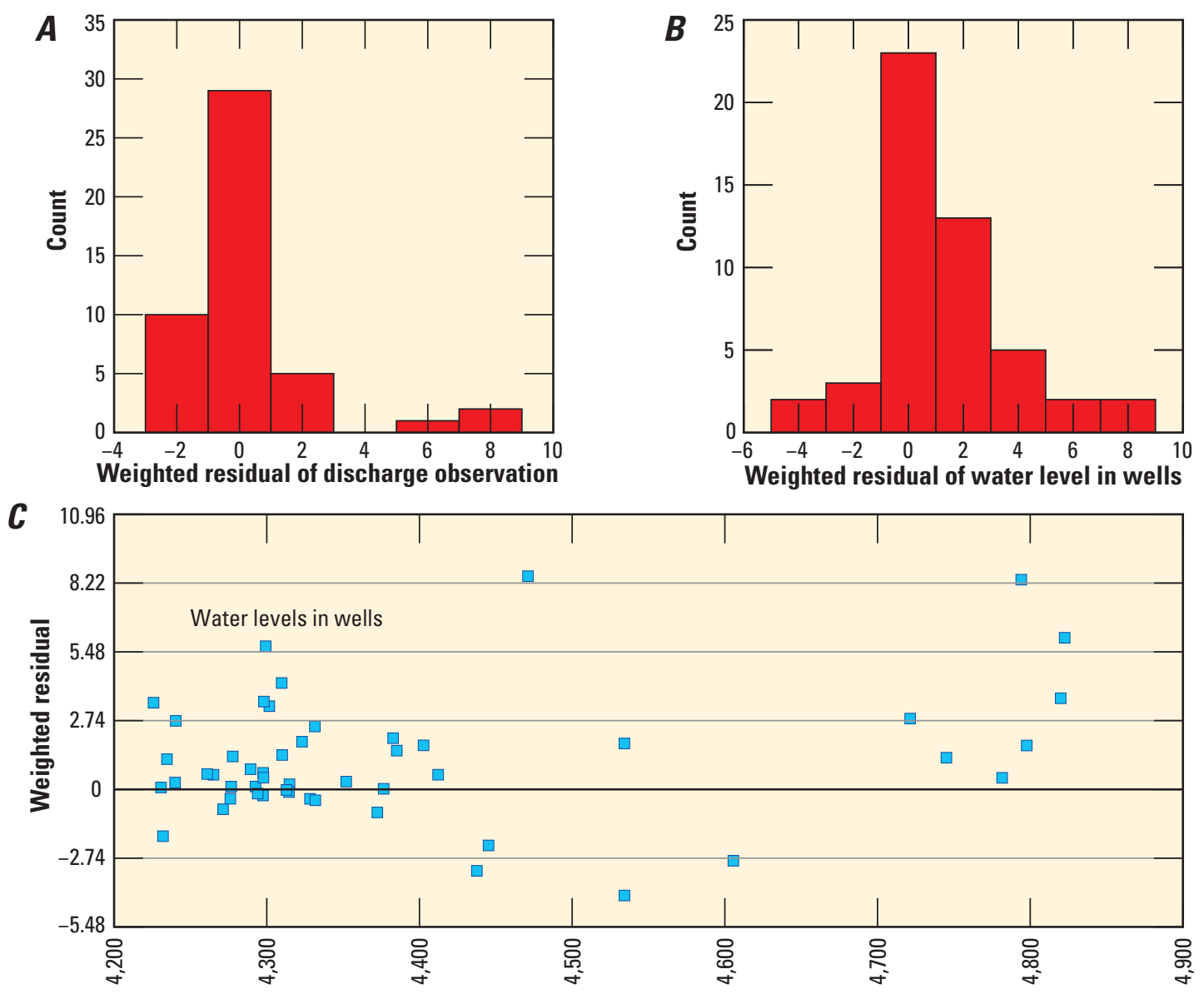

Simulated value, in feet

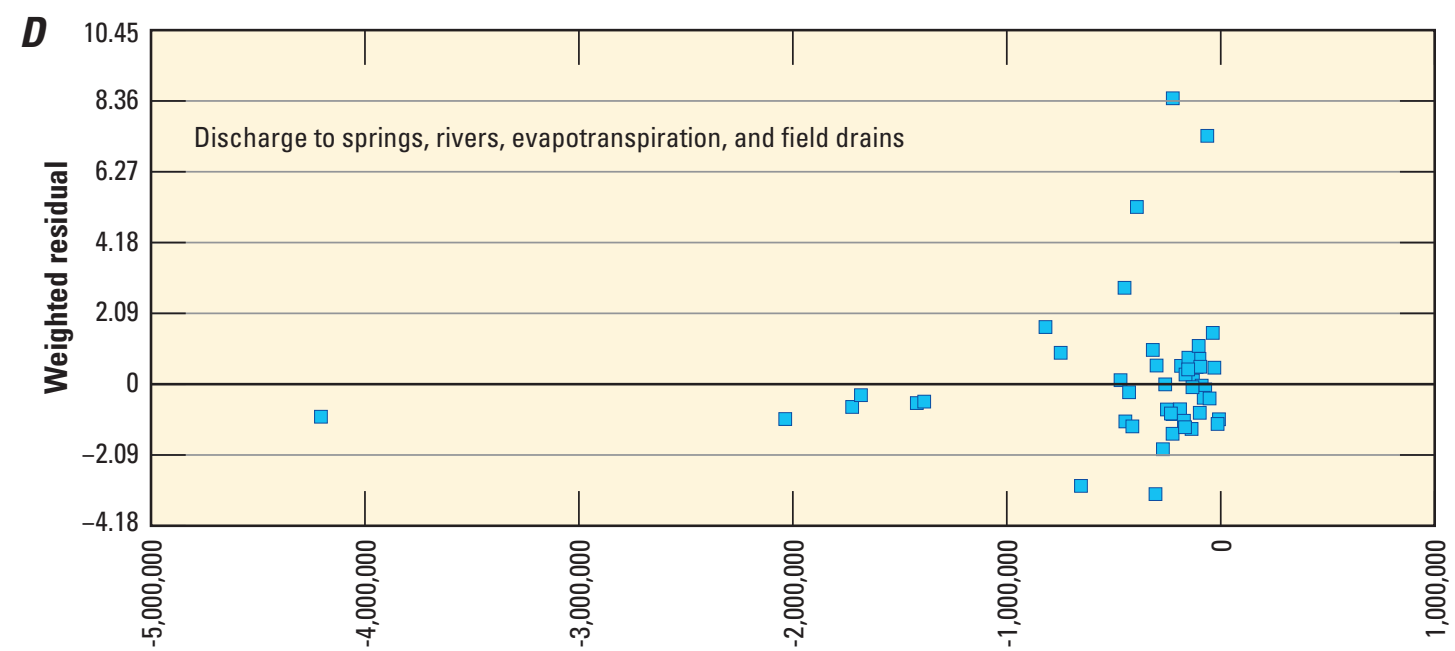

Simulated value, in cubic feet per day

Figure 33. Weighted residuals in the HA273UTchild model, Malad-Lower Bear River study area. $A$, histogram of weighted residuals of discharge, $B$, histogram of weighted residuals of water levels in wells, $C$, weighted residuals of water levels in wells and simulated values, and $D$, weighted residuals of discharge to springs, field drains, rivers, and evapotranspiration, and simulated values. 
of observations in wells of $27.9 \mathrm{ft}$ (table 10) indicates that the model has an overall fit to water levels in wells of $76 \mathrm{ft}$. Eighty-eight percent of the simulated values of observations of water levels in wells are within $76 \mathrm{ft}$ (1 standard deviation of the error) of the observation, and 48 percent of them are within $20 \mathrm{ft}$ (table A3-1, fig. 34). The largest residuals are typically in areas in or near mountains, where complex geology may not be represented in the model. Graphs of weighted residuals and simulated values (fig. 33C) indicate model bias, with more weighted residuals positive than negative; this indicates simulated values are generally less than the observed values. Even though calibration did not concentrate on water levels, for water-level observations used in both GBCAAS v. 1.0 and the HA273UTchild model, the average standard deviation was reduced from 1.85 to 1.29 (table A3-1).

\section{Discharge Observations}

Calibration included matching groundwater discharge to rivers, springs, field drains, and ETg. Simulating accurate discharge was considered important in simulating the groundwater budget and in adequately simulating the groundwater system to create maps showing the effects of projected groundwater withdrawals. The fit of simulated to observed discharge in the HA273UTchild model is generally good. The standard error of the regression of 2.09 (table 14) for discharge observations multiplied by the weighted coefficient of variation of discharge observations of 0.17 (table 10) indicates a coefficient of variation of 0.36 , which is similar to the estimated error in the discharge observations of 0.37. Eighty-four percent of the simulated discharges are within 30 percent of the observed values and 90 percent are within 50 percent of the observed values (table A3-6). Positive and negative residuals are distributed throughout the study area (fig. 35), and graphs of weighted residuals and simulated values (fig. 33D) indicate little model bias; most of the weighted residuals vary randomly about a value of zero. The apparent bias toward more model error with less discharge is an artifact of using the similar coefficients of variation to determine variance and weight of the discharge observations. A smaller discharge has a smaller variance, a higher weight, and possibly a higher weighted residual under this method of weighting.

\section{Water Budget}

The simulated budgets presented in this report are the budgets determined by the model using the calibrated parameters. Uncertainty in the budgets is not presented explicitly; uncertainty in the parameters (fig. 32 and appendix 4), however, provides an approximation of the uncertainty in the water budgets. For example, the uncertainty in recharge parameters (table A4-1) provides one measure of the uncertainty in the budgets, but uncertainty in other parameters also affects the uncertainty of the simulated budgets.
The conceptual and simulated water budgets for the study area are listed in table 15. Simulated recharge from precipitation and irrigation in the study area is 109 percent of the conceptual amount. A conceptual estimate of subsurface inflow is not possible, but one advantage of using local grid refinement within a large model is that subsurface inflow can be a source to meet the discharge in the study area, but is also constrained by calibration of the GBCAASv2parent model to keep the overall calibration of GBCAAS v. 2.0 similar to GBCAAS v. 1.0. GBCAAS v. 2.0 simulates about the same amount of subsurface inflow to HA 273 as GBCAAS v. 1.0, although the distribution of subsurface inflow from surrounding HAs differs (table A6-3). Some of the water that enters the study area from other HAs occurs because the simulated groundwater divide on the Wellsville Mountains is east of the surface-water divide (fig. 36). Total simulated discharge in the study area is 96 percent of the conceptual discharge (table 15).

\section{Simulated Streamflow Capture}

The steady-state MODFLOW-LGR model described in this report was used to examine the effects of pumping on groundwater discharge to the Malad River, the Bear River, and springs. Theis (1940) concluded that all water discharged from wells is balanced by a decrease in storage, a decrease in natural discharge, or an increase in previously rejected recharge. The term "capture" was defined by Lohman and others $(1972$, p. 3) as the combination of decreased discharge and increased recharge. The term capture has been used by many others, including Leake and others (2010) and Konikow and Leake (2014) to describe the effects of groundwater pumping on surface water.

In addition to affecting the Malad River, the Bear River, and springs, groundwater development will also affect field drains, ETg, subsurface inflow to the study area, and discharge in areas outside of the study area. It is also possible in the study area that recharge could be increased in some areas where the current water-table altitude mostly precludes the infiltration of precipitation and irrigation water. That analysis is beyond the scope of this study.

The effect of additional withdrawals is generally described as "capture fraction," which is the fraction of the well discharge that is supplied by reducing streamflow or other groundwater discharge. Using that terminology, the effect on the Malad River is described in this report as the fraction of the well discharge that is supplied by reducing groundwater discharge to the Malad River or increasing groundwater recharge from the Malad River. The first pumping rate used in this analysis is $43,200 \mathrm{ft}^{3} / \mathrm{d}$ (about 360 acre-ft/yr) in model layer 2 (average depth of 100 to $500 \mathrm{ft}$ ) to represent the average discharge and depth of irrigation wells in the study area. A capture fraction of 0.5 for the Malad River, therefore, indicates that $21,600 \mathrm{ft}^{3} / \mathrm{d}$ (181 acre-ft/yr) less flow occurs in the Malad River because of the well. The effect of withdrawals on the Bear River and springs is described in similar fashion. In the 


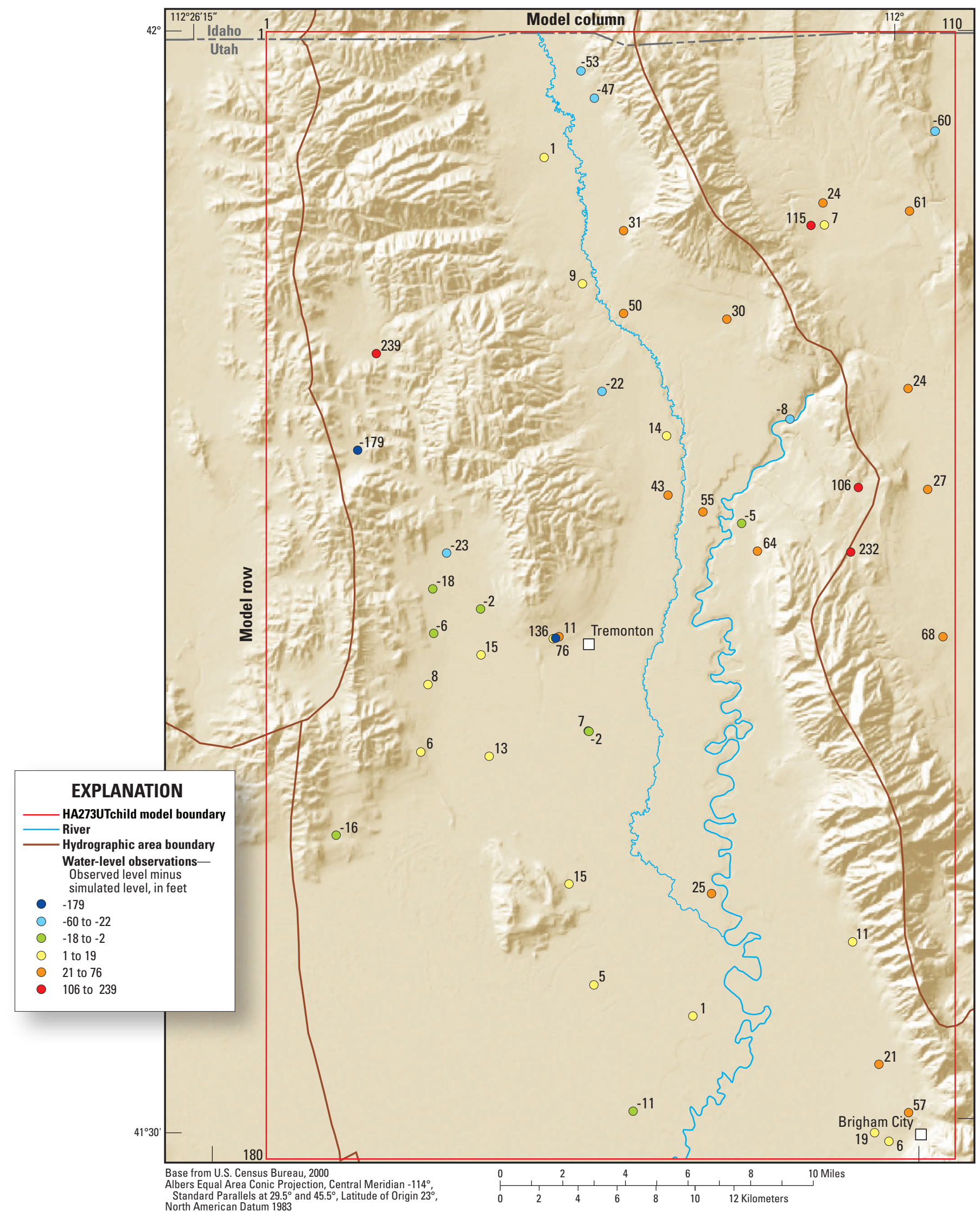

Figure 34. Distribution of residuals of water levels in wells in the HA273UTchild model, Malad-Lower Bear River study area. 


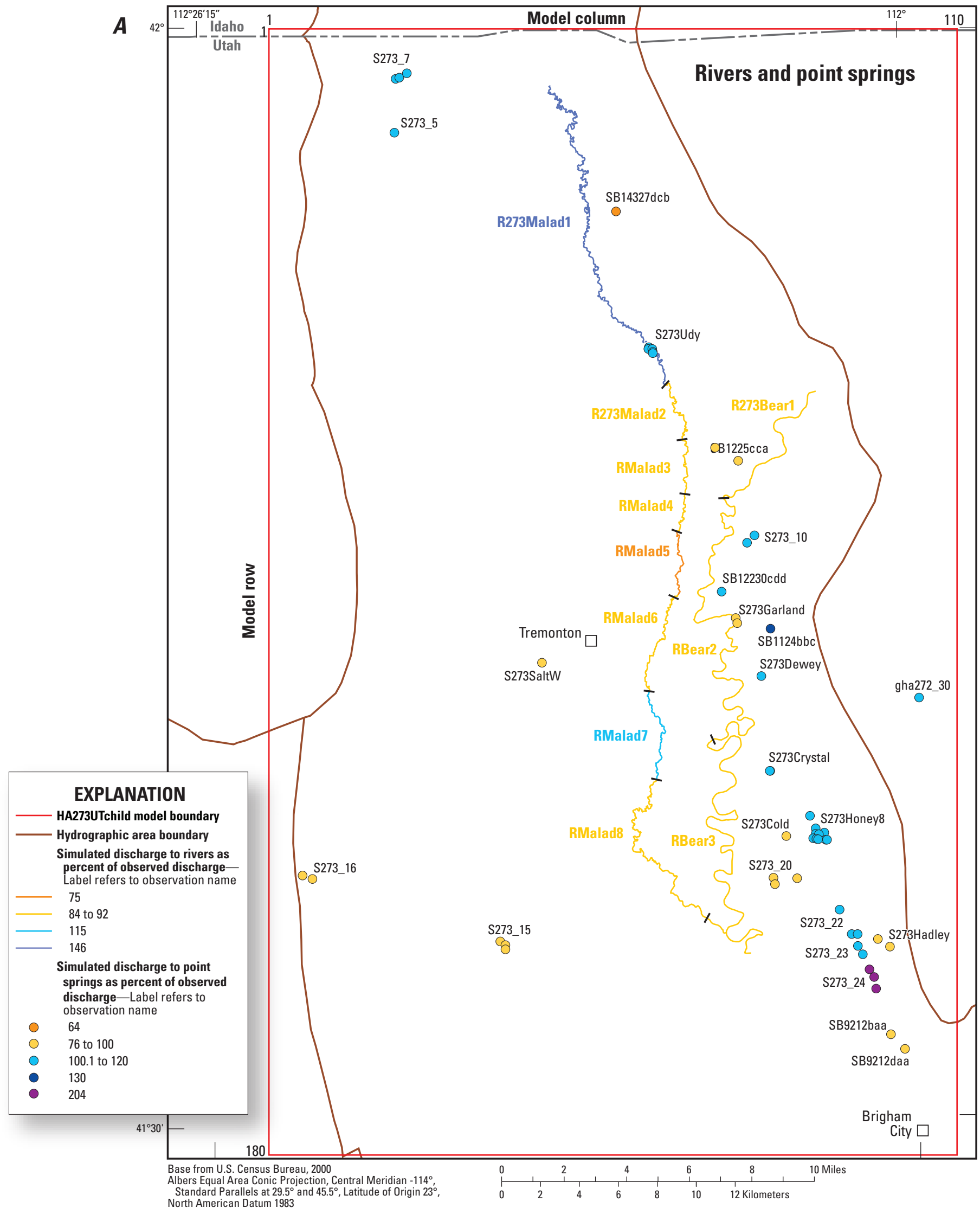

Figure 35. Simulated discharge, as percent of observed discharge in the HA273UTchild model, Malad-Lower Bear River study area. $A$, to rivers and point springs, and $B$, to area springs, field drains, and evapotranspiration. 


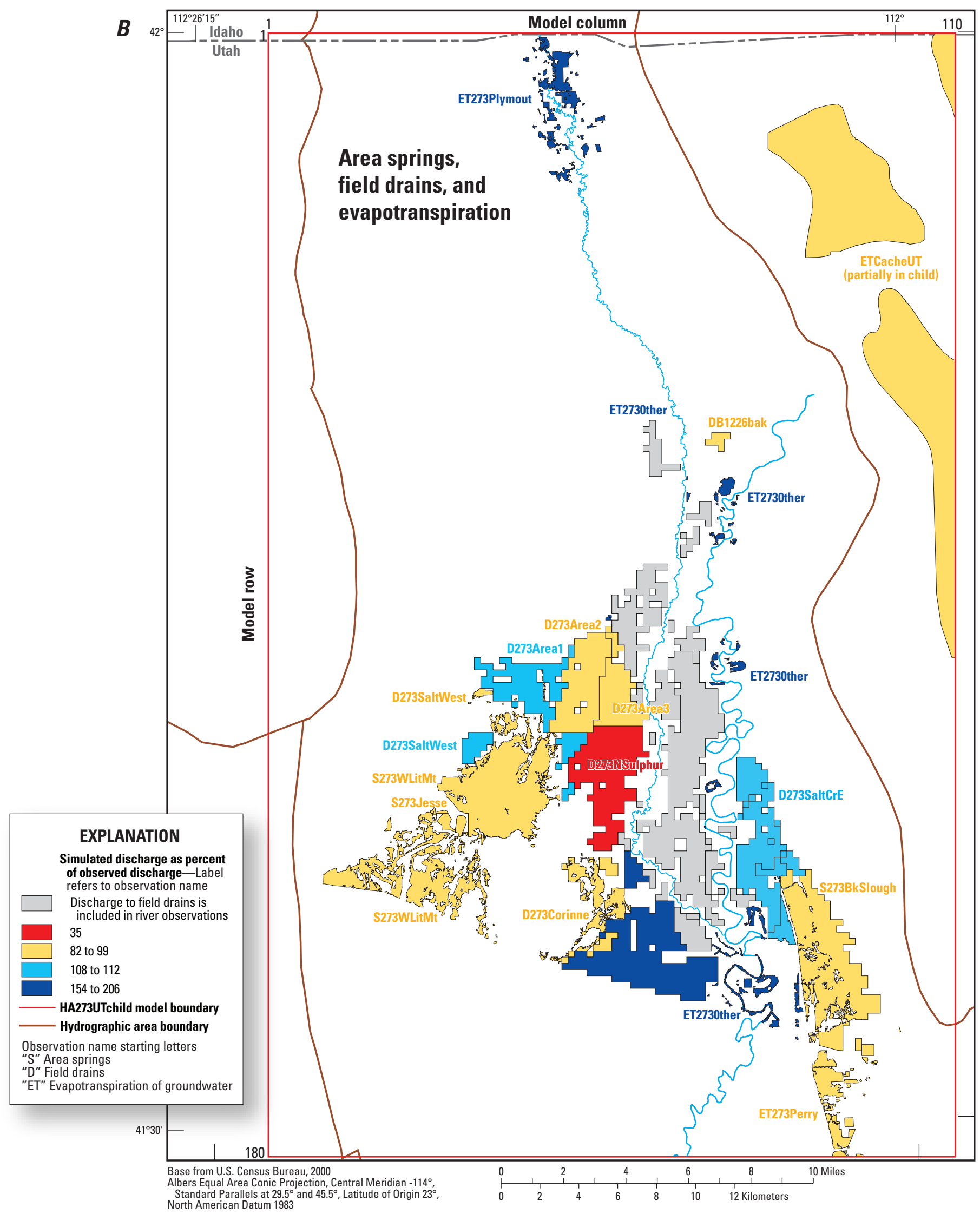

Figure 35. Simulated discharge, as percent of observed discharge in the HA273UTchild model, Malad-Lower Bear River study area. $A$, to rivers and point springs, and $B$, to area springs, field drains, and evapotranspiration.-Continued 
Table 15. Simulated and conceptual groundwater budget, Malad-Lower Bear River study area.

[All flows in acre-feet per year, rounded to two significant figures. Abbreviation: - , not applicable]

\begin{tabular}{|c|c|c|c|c|}
\hline & Child model & Parent model & Total simulated & Conceptual \\
\hline \multicolumn{5}{|c|}{ Recharge } \\
\hline Precipitation on non-irrigated lands & 78,000 & 17,000 & 95,000 & 82,000 \\
\hline Irrigation & 82,000 & 1,000 & 83,000 & 82,000 \\
\hline Net inflow from Idaho within study area & 260 & - & 260 & - \\
\hline Net inflow from other hydrographic areas & 32,000 & 7,800 & 40,000 & - \\
\hline Net inflow from parent model within study area ${ }^{1}$ & 3,200 & - & - & - \\
\hline Total & 200,000 & 26,000 & 220,000 & 160,000 \\
\hline \multicolumn{5}{|c|}{ Discharge } \\
\hline Springs, other field drains, and evapotranspiration & 100,000 & 20,000 & 120,000 & 120,000 \\
\hline Rivers, including field drains to rivers & 87,000 & 0 & 87,000 & 95,000 \\
\hline Great Salt Lake constant-head boundary & - & 1,500 & 1,500 & - \\
\hline Wells ${ }^{2}$ & 9,300 & - & 9,300 & 9,300 \\
\hline Net outflow to child model within study area ${ }^{1}$ & - & 3,900 & - & \\
\hline Total & 200,000 & 25,000 & 220,000 & 220,000 \\
\hline
\end{tabular}

simulations, the net direction of flow is groundwater discharge to the Malad River. Cell-by-cell budgets and simulated water levels along the Malad River were not examined during the capture simulations to determine locations where the flow direction may be reversed to be from the river to groundwater. This is a steady-state model and the results can only be determined for the long-term steady-state condition, or "ultimate" capture; the timing of the capture cannot be determined.

\section{Method}

Capture maps (Leake and others, 2010) were constructed for the HA273UTchild model using the entire model in MODFLOW-LGR. By using both the child and parent models, effects from pumping could be extended to other areas and not be affected by an artificial specified-head boundary at the edge of the child model. The methods described by Leake and others (2010) and Leake and Pool (2010) for creating capture maps were the basis of the methods used in this study and details can be found in those reports. In general, the method consists of the following:

1. Run the calibrated steady-state model.

a. Save values of simulated discharge to the Malad River and field drains that flow directly to the Malad River. These simulated values were calculated using the MODFLOW observation process (Harbaugh and Hill, 2009).

b. Save the simulated values at other model discharge observations, such as springs and the Bear River.

c. Save simulated budget data for both the child and parent models.
2. Add one well at a selected location to the MODFLOWLGR Well Package with a pumping rate of $43,200 \mathrm{ft}^{3} / \mathrm{d}$ in layer 2. Run the model again.

a. Retrieve the simulated values of discharge observations and simulated budget components.

b. Calculate the difference in the simulated values and budget components from the values saved from the calibrated steady-state model.

c. Divide these differences by the pumping rate to obtain the capture fraction for each observation or for each budget component. Save the capture fractions.

3. Complete step two for all desired locations of added wells.

4. Map the fraction of capture from the Malad River, the Bear River, and springs for the area over which wells were simulated.

For this report, the wells were placed at various spacings to provide adequate locations for interpolation; the spacing ranged from about $0.25 \mathrm{mi}$ near the Malad River to a maximum of about $1.5 \mathrm{mi}$ on the edges of the study area.

\section{Results}

The results from each capture analysis were interpolated to produce a map that shows, for each location in the study area, the amount of simulated capture from the Malad River, Sulphur Creek, and field drains that flow directly to the Malad River or Sulphur Creek (fig. 37). The northern part of the study area has little natural discharge other than to the Malad River (figs. 26 and 27), and groundwater development near the river has a large effect on the flow in the river. Along the 


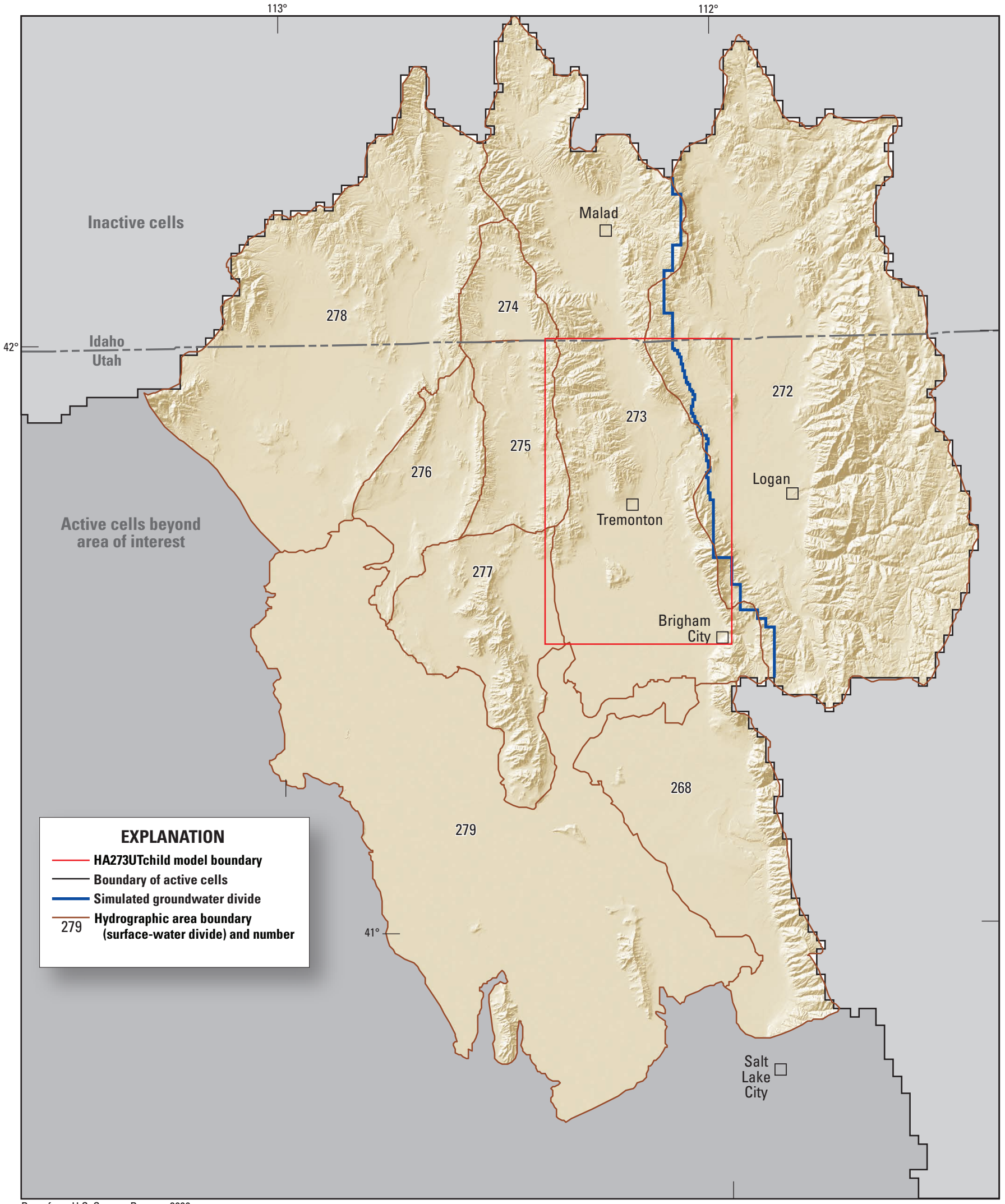

Base from U.S. Census Burrau, 2000

Albers Equal Area Conic Projection, Central Meridian -114

Stan Amd Parallels at $29.5^{\circ}$ and $45.5^{\circ}$, Latitude of Origin $23^{\circ}$,

\begin{tabular}{|c|c|c|c|c|c|c|}
\hline 0 & & & 20 & & 30 & 40 Miles \\
\hline 0 & 10 & 20 & 30 & 40 & & \\
\hline
\end{tabular}

Figure 36. Selected simulated groundwater divide in the GBCAAS v. 2.0 groundwater model, Malad-Lower Bear River study area and surrounding areas, Utah and Idaho. 

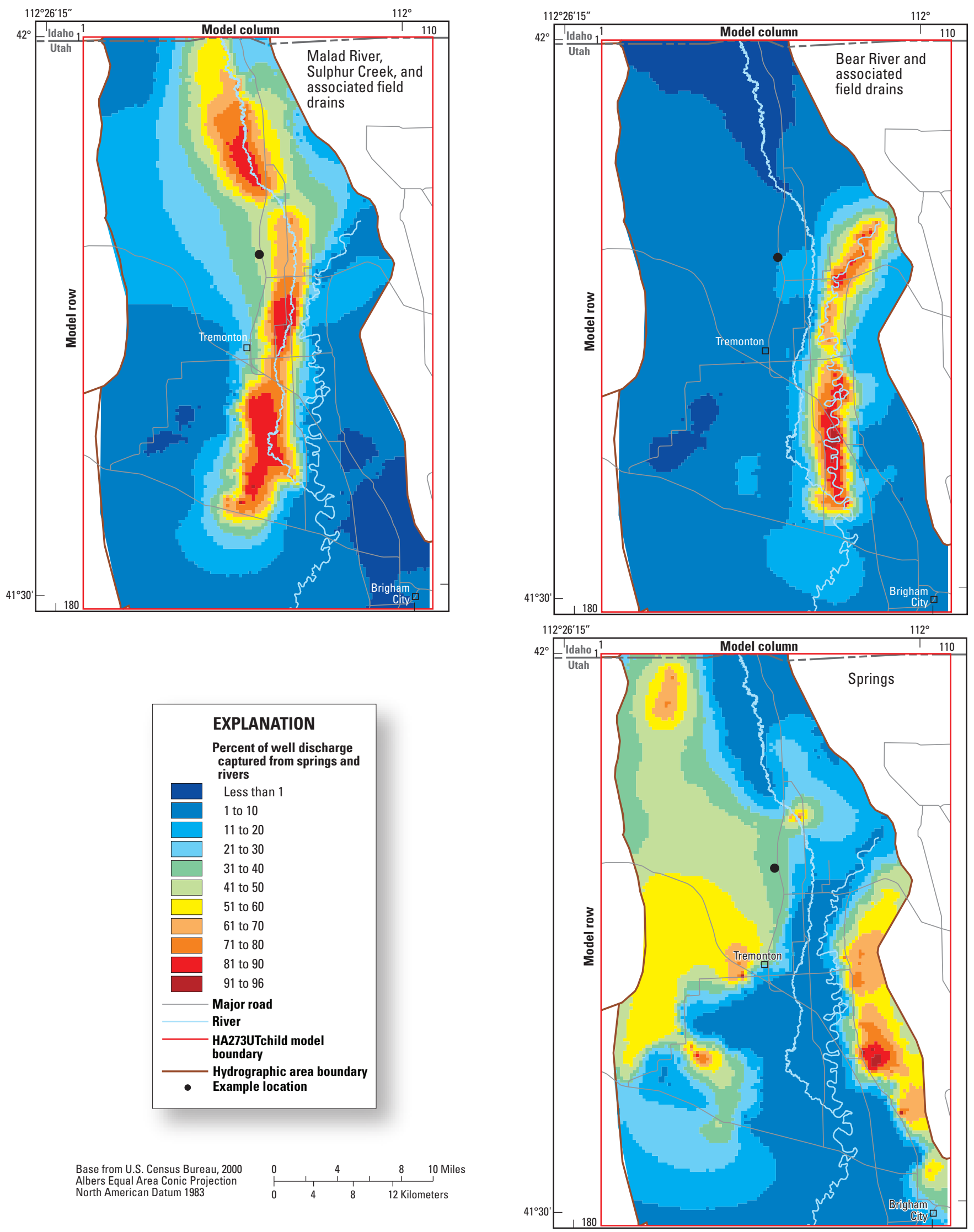

Figure 37. Simulated reduction in flow in the Malad River, Sulphur Creek, the Bear River, and springs as a fraction of pumping rate that would result from long-term pumping from layer 2 at a pumping rate of 43,200 cubic feet per day, Malad-Lower Bear River study area. 
middle and southern reaches of the Malad River and Sulphur Creek, many field drains discharge to the river or creek. The simulated well captures water that was going to these drains, and therefore has a large effect on flow in the river and creek. Areas along the Malad River that have less effect are near springs and areas of ETg that are also captured by the well.

The maps (fig. 37) show that withdrawal anywhere will reduce streamflow or other discharge by the amount of the withdrawal. As an example, a well pumping 362 acre-ft/yr at the point shown on figure 37 would derive 42 percent of its discharge from the Malad River, 36 percent from various springs, 10 percent from the Bear River, 8 percent from other field drains or ETg, and 4 percent from increasing subsurface inflow from outside of the study area. If the model was linear, these results would apply for any pumping rate and any combination of pumping wells. Because of the extensive head-dependent boundaries (figs. 26 and 27) in this model, however, the model is not linear and the responses shown on figure 37 are strictly applicable with only one well with a pumping rate of $43,200 \mathrm{ft}^{3} / \mathrm{d}$. An analysis of different pumping rates shows little difference in the percent capture except near small springs. At those locations, a smaller withdrawal rate will mostly capture the nearby spring and have less effect on the Malad River. At larger withdrawal rates, the small spring is completely captured (becomes dry) and the Malad River and other discharge areas are affected to a greater percent.

To test if simulated well depth and horizontal-to-vertical anisotropy has an effect on capture, withdrawals from model layer 3 were also simulated. For the Malad River, the difference in capture for withdrawals in model layer 2 (average depth of 100 to $500 \mathrm{ft}$ ) minus capture for withdrawals in model layer 3 (average depth of 500 to 1,000 ft) are shown on figure 38. In areas near the central part of the Malad River, Sulphur Creek, and field drains to the river and creek, withdrawals in layer 2 have a better hydraulic connection to the rivers and drains in layer 1 than do the withdrawals in layer 3. Because of this, withdrawals in layer 2 capture a larger percent of their discharge from the Malad River, Sulphur Creek, and the field drains than do withdrawals in layer 3 (fig. 38). Near the Bear River and other areas of field drains or ETg, wells in layer 3 have less hydraulic connection to those features, capture less from them, and capture a higher percent of their discharge from the Malad River.

\section{Applicability}

These capture maps can be used to help water managers and the public understand that all groundwater development will affect surface-water features or areas of groundwater discharge. The maps are best used to help understand how the position of a well determines which features are affected the most. The results illustrate key points that may be useful in developing water management scenarios in the Malad-Lower Bear River study area. First, if development occurs near a spring or near the Bear River, capture of the Malad River will be less. Second, if development occurs near field drains to the Malad River, flow in the Malad River may also be reduced.

The maps can be used as an assessment of locations in which development may or may not have unacceptable effects. The maps are based on simulated transmissivity, anisotropy, and riverbed conductance and should not be considered absolutely accurate at any one location because of the uncertain nature of these parameters. The model and the maps represent hydraulic properties that appear reasonable on the basis of water levels and discharge estimates, but that are not perfect. Regardless of the inaccuracies, the model provides a better tool for estimating the effects of groundwater development than analytical solutions because the complexities of the system are included in the numerical model. An analysis of the sensitivity of these capture maps to various hydraulic properties was not performed, but analyses performed along the Colorado River in Arizona and California (Leake and others, 2013, fig. 6) indicated that varying properties over reasonable ranges may affect the capture by as much as 20 percent, but the largest differences are close to the location of discharge.

\section{Model Limitations}

This model was developed to simulate general groundwater flow throughout the Malad-Lower Bear River study area. It was not developed to simulate local effects of withdrawals or water budgets on a cell-by-cell basis. All groundwater flow models are based on a limited amount of data and are simplifications of natural systems. Model limitations are a consequence of simplifications, inadequacies, or inaccuracies in (1) representation of the geologic complexity in the hydrogeologic framework and model, (2) representation of recharge and discharge boundaries, and (3) observations used in the model. These limitations are described in Brooks and others (2014, p. 84-85) and are summarized here.

Limitations exist in the numerical flow model because of the difficulties inherent in the interpretation and representation of the complex geometry and spatial variability of hydrogeologic materials and structures in the hydrogeologic framework and because the model cell size limits the resolution of the framework in the model. Detailed stratigraphy not represented in the hydrogeologic framework may cause some of the mismatch between simulated and observed hydraulic gradients and heads. It is possible that different parameter zone boundaries could be selected that would provide a similar or better model fit and that additional zones exist that are not simulated because geologic or hydrologic data are not available to delineate them. It is also possible that faults that are not simulated with the HFB Package could act as similar barriers to groundwater flow, but that water-level data are not available to delineate these areas.

Recharge probably varies more across the assigned zones than is simulated. For instance, recharge is dependent on vertical hydraulic conductivity of the materials present at the surface and at the groundwater table. Horizontal flow can 


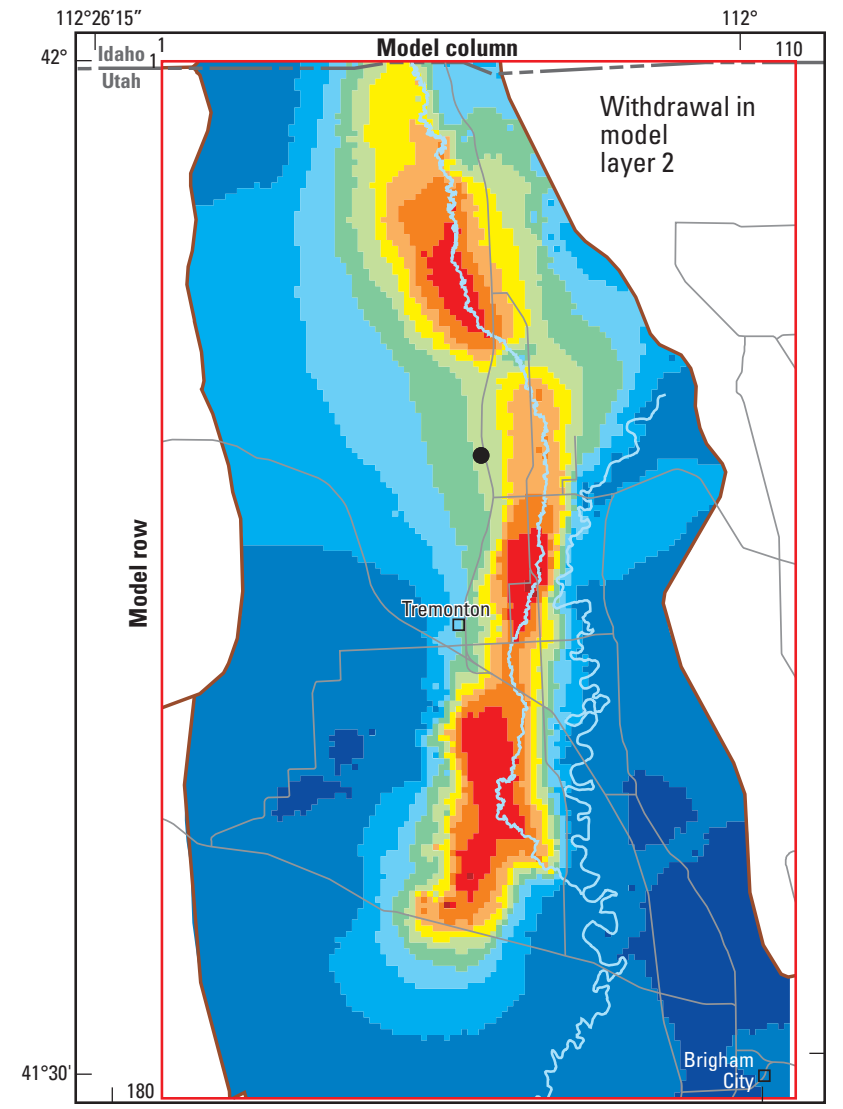

\section{EXPLANATION}

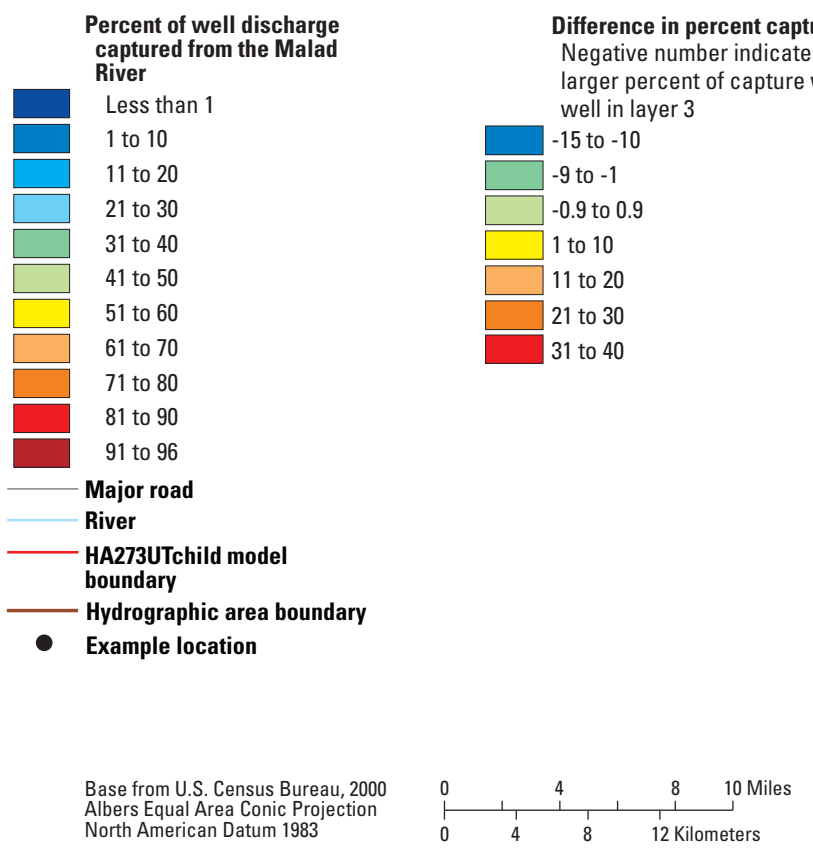

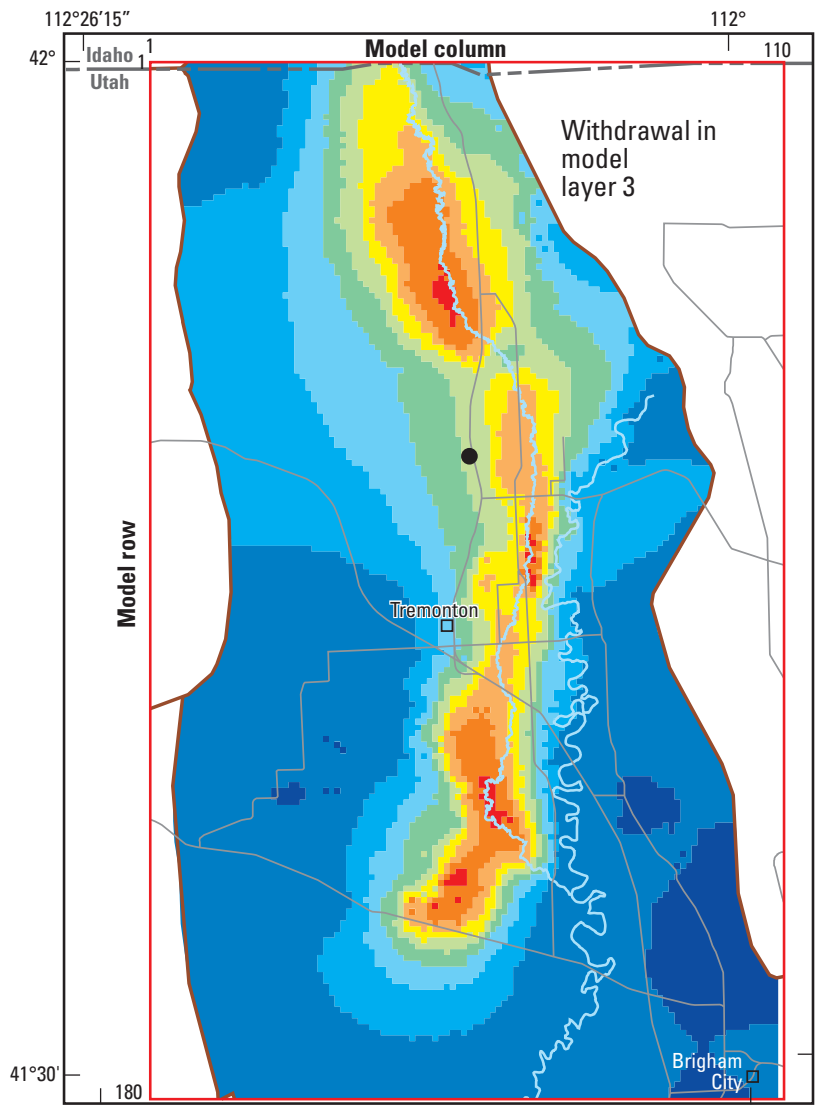

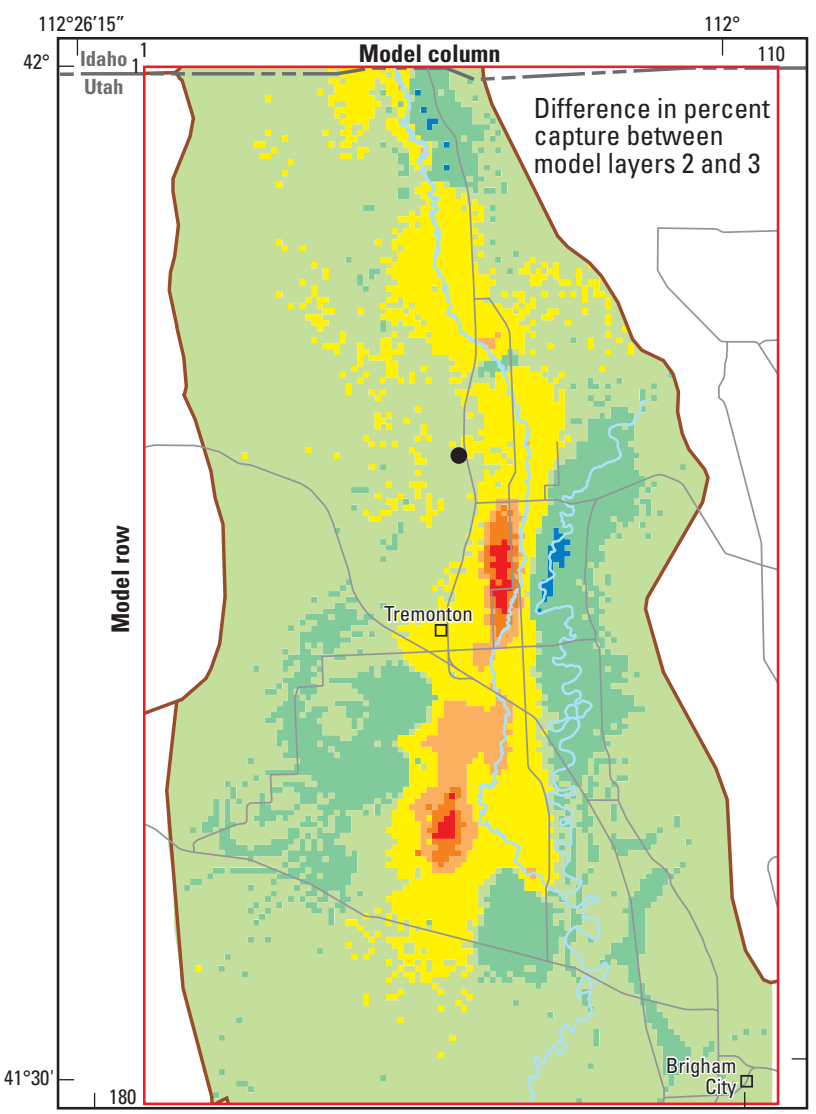

Figure 38. Simulated reduction in flow in the Malad River as a fraction of pumping rate that would result from long-term pumping from layer 2 and layer 3 at a pumping rate of 43,200 cubic feet per day, and the difference in capture percent between layers 2 and 3, MaladLower Bear River study area. 
occur at either of these locations until a more permeable material is encountered. Recharge is also dependent on irrigation practices and can vary on a field by field basis.

Observations of water levels and groundwater discharge constrain model calibration. Uncertainty in these observations introduces uncertainty in the results of the numerical model. Although the water level and discharge observations used in this model were analyzed prior to and throughout calibration, there was uncertainty regarding the accuracy of the observation data. Discharge observations are based on limited data and may not represent the system correctly.

\section{Appropriate Uses of the Model}

The Malad-Lower Bear River child model (HA273UTchild) was developed for the purpose of testing the conceptual groundwater budget and developing a tool to estimate the long-term effect of additional groundwater withdrawals on the Malad River. The model can also be used to investigate other effects on the natural system including (1) the ultimate effects of different recharge throughout the area or large parts of the area, (2) different interpretations of the extent or offset of faults or fault zones, or (3) different conceptual models of depositional environments or tectonic/structural events that would affect the spatial variation of hydraulic properties. This model is a steady-state model; it does not include storage properties, and storage properties were not estimated as part of this study. The model cannot be used to evaluate the timing of the effects of increased withdrawals or other changes, only the long-term (ultimate) results.

The model and statistics from programs such as UCODE_2005 (Poeter and others, 2008) and OPR-PPR (Tonkin and others, 2007) can be used to guide data collection that will be the most useful in reducing prediction uncertainty. The model can be used less formally to guide data collection by consideration of zonation and parameter values that were needed to achieve calibration in selected areas and what data could be collected to verify or dispute the model parameters.

\section{Summary}

The Malad-Lower Bear River study area is located in Box Elder County, Utah, about 70 mi north of Salt Lake City, Utah. The area consists of a valley bounded by mountain ranges, and is mostly agricultural or undeveloped. The Bear and Malad Rivers enter the study area with a combined average flow of about 1,100,000 acre-ft/yr, and this surface water dominates the hydrology. Canals distribute an average of 240,000 acre-ft/yr of surface water to croplands and wetlands north of Great Salt Lake. Groundwater, including springs, supplies municipal and domestic water. Withdrawal from wells is a small component of the groundwater budget, and groundwater development has had little effect on the groundwater system. Increases in groundwater appropriation, however, are being requested, and there is concern that additional groundwater development will reduce the amount of flow in the Malad River. This study reassesses the hydrologic system, refines the groundwater budget, and creates a numerical groundwater flow model that is used to analyze the effects of groundwater withdrawal on surface water.

Groundwater occurs in consolidated rock and basin fill. The basin fill and underlying and adjacent consolidated rock are considered a single groundwater flow system. Groundwater that is recharged from precipitation in the mountains moves through consolidated rock to the basin fill. Recharge occurs in the valley from irrigation. Discharge occurs to rivers, springs and diffuse seepage areas, evapotranspiration, and field drains. Irrigation and field drains have changed hydrologic conditions within the study area, increasing groundwater discharge to the Malad River from pre-development conditions.

Historical records of surface-water diversions, land use, and groundwater levels indicate relatively stable hydrologic conditions from the 1960s to the 2010s. With the exception of the early 1980s, precipitation had a slight downward trend from 1965 to 2010. The effects of less precipitation have not been detected in groundwater discharge to springs and rivers, or to groundwater levels. Average annual groundwater recharge to and discharge from the groundwater flow system are estimated to be 164,000 and 228,000 acre-ft/yr, respectively. The imbalance between recharge and discharge represents uncertainties resulting from system complexities and the possibility of groundwater inflow from surrounding basins. Budget components are estimated independently, with no assumption that discharge must equal recharge. Total budget amounts are approximately two-thirds of the amounts determined previously. The difference does not reflect a fundamental change in hydrologic conditions, but results from improved accounting of surface water made possible by additional streamflow data, more detailed analysis of groundwater recharge from precipitation and irrigation, and better estimates of groundwater discharge.

To better understand the relation between additional groundwater development and groundwater discharge to the Malad River, a numerical groundwater flow model was developed. The model uses the detailed cataloging of locations and amounts of groundwater recharge and discharge defined during this study. Developing the model to adequately simulate recharge, discharge, and groundwater levels results in simulated aquifer properties that can be used to understand the relation between pumping and reduction in discharge to rivers, springs, and natural vegetation.

The numerical groundwater flow model is a version of the steady-state numerical model of the Great Basin carbonate and alluvial aquifer system that is refined within the study area. The advantage of embedding a detailed simulation within the regional model is the determination of groundwater flow into and out of the study area on the basis of simulated recharge, discharge, and aquifer properties rather than a set of pre-defined conditions. The model includes recharge from precipitation and irrigation, and discharge to rivers, springs, 
evapotranspiration, field drains, and wells. The model is calibrated to match water levels in wells; altitudes of selected springs; and discharge to rivers, springs, natural vegetation, and field drains. The calibrated model is used to calculate the reduction of groundwater discharge to the Malad River (stream depletion) in response to a well withdrawal of 360 acre-ft/yr at any location within the study area. Modeling results show that streamflow depletion in the Malad River depends on both depth and location of groundwater withdrawal. The relation between simulated withdrawal and reduction in Malad River streamflow is shown on capture maps. Maps also show the relation between simulated withdrawals and reductions in Bear River streamflow and spring discharge.

\section{References}

Anderman, E.R., and Hill, M.C., 2000, MODFLOW-2000, the U.S. Geological Survey modular ground-water modelDocumentation of the Hydrogeologic-Unit Flow (HUF) Package: U.S. Geological Survey Open-File Report 00-342, $89 \mathrm{p}$.

Anderman, E.R., and Hill, M.C., 2003, MODFLOW-2000, the U.S. Geological Survey modular ground-water modelThree additions to the Hydrogeologic-Unit Flow (HUF) Package: Alternative storage for the uppermost active cells, Flows in hydrogeologic units, and the Hydraulic-conductivity depth-dependence (KDEP) capability: U.S. Geological Survey Open-File Report 03-347, 36 p.

Anderson, P.B., Susong, D.D., Wold, S.R., Heilweil, V.M., and Baskin, R.L., 1994, Hydrogeology of recharge areas and water quality of the principal aquifers along the Wasatch Front and adjacent areas, Utah: U.S. Geological Survey Water-Resources Investigations Report 93-4221, 74 p., 5 pls.

Belcher, W.R., Sweetkind, D.S., and Elliot, P.E., 2002, Probability distributions of hydraulic conductivity for the hydrogeologic units of the Death Valley regional groundwater flow system, Nevada and California: U.S. Geological Survey Water-Resources Investigations Report 02-4212, $18 \mathrm{p}$.

Bjorklund, L.J., and McGreevy, L.J., 1973, Selected hydrologic data, Lower Bear River drainage basin, Box Elder County, Utah: Utah Department of Natural Resources Utah Basic-Data Release No. 23, 22 p., 1 pl.

Bjorklund, L.J., and McGreevy, L.J., 1974, Ground-water resources of the Lower Bear River drainage basin, Box Elder County, Utah: Utah Department of Natural Resources Technical Publication No. 44, 65 p., 5 pls.
Brooks, L.E., Masbruch, M.D, Sweetkind, D.S., and Buto, S.G., 2014, Steady-state numerical flow model of the Great Basin carbonate and alluvial aquifer system study area: U.S. Geological Survey Scientific Investigations Report 20145213, 124 p., 2 pls.

Burden, C.B., and others, 2015, Groundwater conditions in Utah, Spring of 2015: Utah Department of Natural Resources Cooperative Investigations Report No. 56, 136 p.

Buto, S.G., 2011, Description of spatial datasets accompanying the conceptual model of the Great Basin carbonate and alluvial aquifer system, appendix 6 of Heilweil, V.M., and Brooks, L.E., eds., Conceptual model of the Great Basin carbonate and alluvial aquifer system: U.S. Geological Survey Scientific Investigations Report 2010-5193, p. $177-179$.

Caine, J.S., Evans, J.P., and Forster, C.B., 1996, Fault zone architecture and permeability structure: Geology, v. 24 , p. 1025-1028, http://geology.gsapubs.org/content/24/11/1025.

Cederberg, J.R., Sweetkind, D.S., Buto, S.G., and Masbruch, M.D., 2011, Three-dimensional hydrogeologic framework, appendix 1 of Heilweil, V.M., and Brooks, L.E., eds., Conceptual model of the Great Basin carbonate and alluvial aquifer system: U.S. Geological Survey Scientific Investigations Report 2010-5193, p. 127-142.

Christensen, S., and Cooley, R.L., 1999, Evaluation of confidence intervals for a steady-state leaky aquifer model: Advances in Water Resources, v. 22, no. 8, p. 807-817.

Currey, D.R., Atwood, G., and Mabey, D.R., 1984, Major levels of Great Salt Lake and Lake Bonneville: Utah Department of Natural Resources, Utah Geological and Mineral Survey Map 73.

Fenneman, N.M., 1931, Physiography of the western United States: New York, McGraw-Hill, 534 p.

Flint, A.L., Flint, L.E., and Masbruch, M.D., 2011, Input, calibration, uncertainty, and limitations of the Basin Characterization Model, appendix 3 of Heilweil, V.M., and Brooks, L.E., eds., Conceptual model of the Great Basin carbonate and alluvial aquifer system: U.S. Geological Survey Scientific Investigations Report 2010-5193, p. 149-164.

Goedhart, C.M., and Pataki, D.E., 2011, Ecosystem effects of groundwater depth in Owens Valley, California: Ecohydrology, v. 4, issue 3, p. 458-468.

Goessel, K.M., Oaks, R.Q., Jr., Perkins, M.E., and Janecke, S.U., 1999, Tertiary stratigraphy and structural geology, Wellsville Mountains to Junction Hills, north-central Utah, in Spangler, L.E., ed., Geology of northern Utah and vicinity, 1999: Utah Geological Association Publication 27, p. $45-69$. 
Harbaugh, A.W., 2005, MODFLOW-2005, the U.S. Geological Survey modular ground-water model-The groundwater flow process: U.S. Geological Survey Techniques and Methods 6-A16 [variously paged].

Harbaugh, A.W., and Hill, M.C., 2009, Observations in MODFLOW-2005-File OBS.pdf distributed with MODFLOW-2005: U.S. Geological Survey, 32 p., accessed on February 14, 2013, at http://water.usgs.gov/nrp/gwsoftware/ modflow2005/modflow2005.html.

Harrill, J.R., Gates, J.S., and Thomas, J.M., 1988, Major ground-water flow systems in the Great Basin region of Nevada, Utah, and adjacent states: U.S. Geological Survey Hydrologic Investigations Atlas HA-694-C, 2 sheets, scale 1:1,000,000.

Harrill, J.R., and Prudic, D.E., 1998, Aquifer systems in the Great Basin region of Nevada, Utah, and adjacent statesSummary report: U.S. Geological Survey Professional Paper 1409-A, $66 \mathrm{p}$.

Heilweil, V.M., and Brooks, L.E., eds., 2011, Conceptual model of the Great Basin carbonate and alluvial aquifer system: U.S. Geological Survey Scientific Investigations Report 2010-5193, 191 p.

Hill, M.C., and Tiedeman, C.R., 2007, Effective groundwater model calibration - With analysis of data, sensitivities, predictions, and uncertainty: Hoboken, N.J., John Wiley and Sons, Inc., 455 p.

Hill, R.W., Barker, J.B., and Lewis, C.S., 2011, Crop and wetland consumptive use and open water surface evaporation for Utah, final report, appendix J-Updated consumptive use estimates at EWS sites: Utah Agricultural Experiment Station Research Report no. 213, 101 p.

Homer, C.G., Dewitz, J.A., Yang, L., Jin, S., Danielson, P., Xian, G., Coulston, J., Herold, N.D., Wickham, J.D., and Megown, K., 2015, Completion of the 2011 National Land Cover Database for the conterminous United StatesRepresenting a decade of land cover change information: Photogrammetric Engineering and Remote Sensing, v. 81, no. 5 , p. $345-354$.

Hurlow, H.A., 1999, Preliminary hydrogeologic framework characterization-Ground-water resources along the western side of the northern Wasatch Range, eastern Box Elder County, Utah: Utah Geological Survey Special Circular 101, 11 p., 4 appendixes.

Inkenbrandt, P.C., and Lachmar, T.E., 2012, Estimating hydraulic parameters in Cache Valley, Utah with application to engineering and environmental geology, in Hylland, M.D., and Harty, K.M., eds., Selected topics in engineering and environmental geology in Utah: Utah Geological Association Publication 41, p. 69-84.
Kendall, Carol, and Coplen, T.B., 2001, Distribution of oxygen-18 and deuterium in river waters across the United States: Hydrological Processes, v. 15, p. 1363-1393, doi: 10.1002/hyp.217.

Konikow, L.F., and Leake, S.A., 2014, Depletion and capture-Revisiting "the source of water derived from wells": Groundwater, v. 52, supplement 1, p. 100-111, doi: 10.111/gwat.12204.

Leake, S.A., Owen-Joyce, S.J., and Heilman, J.A., 2013, Potential depletion of surface water in the Colorado River and agricultural drains by groundwater pumping in the Parker-Palo Verde-Cibola area, Arizona and California: U.S. Geological Survey Scientific Investigations Report 2013-5134, 13 p.

Leake, S.A., and Pool, D.R., 2010, Simulated effects of groundwater pumping and artificial recharge on surfacewater resources and riparian vegetation in the Verde Valley sub-basin, central Arizona: U.S. Geological Survey Scientific Investigations Report 2010-5147, 18 p.

Leake, S.A., Reeves, H.W., and Dickinson, J.E., 2010, A new capture fraction method to map how pumpage affects surface water flow: Ground Water, v. 48, issue 5, p. 690-700, doi: 10.1111/j.1745-6584.2010.00701.x.

Lohman, S.W., and others, 1972, Ground-water terms-Revisions and conceptual refinements: U.S. Geological Survey Water-Supply Paper 1988, 21 p.

Mann, H.B., and Whitney, D.R., 1947, On a test of whether one of two random variables is stochastically larger than the other: The Annals of Mathematical Statistics, v. 18, no. 1, p. 50-60, accessed on April 20, 2016, at http://www.jstor.org/stable/2236101.

Masbruch, M.D., 2011a, Current study groundwater recharge estimates for predevelopment conditions and ranges of previously reported estimates of groundwater recharge for each hydrographic area within the Great Basin carbonate and alluvial aquifer system study area, appendix 4 of Heilweil, V.M., and Brooks, L.E., eds., Conceptual model of the Great Basin carbonate and alluvial aquifer system: U.S. Geological Survey Scientific Investigations Report 2010-5193, p. $165-170$.

Masbruch, M.D., 2011b, Current study groundwater discharge estimates for predevelopment conditions and ranges of previously reported estimates of groundwater discharge for each hydrographic area within the Great Basin carbonate and alluvial aquifer system study area, appendix 5 of Heilweil, V.M., and Brooks, L.E., eds., Conceptual model of the Great Basin carbonate and alluvial aquifer system: U.S. Geological Survey Scientific Investigations Report 2010-5193, p. 171-176. 
Masbruch, M.D., Heilweil, V.M., Buto, S.G., Brooks, L.E., Susong, D.D., Flint, A.L., Flint, L.E., and Gardner, P.M., 2011, Groundwater budgets, chap. D of Heilweil, V.M., and Brooks, L.E., eds., Conceptual model of the Great Basin carbonate and alluvial aquifer system: U.S. Geological Survey Scientific Investigations Report 2010-5193, p. 73-126.

Mathey, S.B., ed., 1998, National Water Information System (NWIS): U.S. Geological Survey Fact Sheet 027-98, 2 p.

McGreevy, L.J., 1972, Specific-conductance survey of the Malad River, Utah and Idaho: U.S. Geological Survey Professional Paper 800-C, p. C239-C242.

Mehl, S.W, and Hill, M.C., 2013, MODFLOW-LGR-Documentation of ghost node local grid refinement (LGR2) for multiple areas and the boundary flow and head (BFH2) package: U.S. Geological Survey Techniques and Methods 6-A44, $43 \mathrm{p}$.

National Agriculture Imagery Program, 2011, Utah NAIP 2011 Imagery, USDA FSA Aerial Photography Field Office, Salt Lake City, Utah.

Poeter, E.P., Hill, M.C., Banta, E.R., Mehl, Steffen, and Christensen, Steen, 2005, UCODE_2005 and six other computer codes for universal sensitivity analysis, calibration, and uncertainty evaluation, revised February 2008: U.S. Geological Survey Techniques and Methods 6-A11, $283 \mathrm{p}$.

Reilly, T.E., 2001, System and boundary conceptualization in ground-water flow simulation: U. S. Geological Survey Techniques of Water-Resources Investigations, book 3 , chap. B8, 30 p.

Reilly, T.E., and Harbaugh, A.W., 2004, Guidelines for evaluating ground-water flow models: U.S. Geological Survey Scientific Investigations Report 2004-5038, 30 p.

San Juan, C.A., Belcher, W.R., Laczniak, R.J., and Putnam, H.M., 2004, Hydrologic components for model development, chap. C of Belcher, W.R., ed., Death Valley regional ground-water flow system, Nevada and California-Hydrologic framework and transient ground-water flow model: U.S. Geological Survey Scientific Investigations Report 2004-5205, p. 103-136.

Sweetkind, D.S., Cederberg, J.R., Masbruch, M.D., and Buto, S.G., 2011, Hydrogeologic framework, chap. B of Heilweil, V.M., and Brooks, L.E., eds., Conceptual model of the Great Basin carbonate and alluvial aquifer system: U.S. Geological Survey Scientific Investigations Report 2010-5193, p. $15-50$.

Theis, C.V., 1940, The source of water derived from wellsEssential factors controlling the response of an aquifer to development: Civil Engineering, v. 10, no. 5, p. 277-280.

Todd, D.K., 1980, Groundwater hydrology: New York, John Wiley and Sons, $535 \mathrm{p}$.
Tonkin, M.J., Tiedeman, C.R., Ely, D.M., and Hill, M.C., 2007, OPR-PPR, a computer program for assessing data importance to model predictions using linear statistics: U.S. Geological Survey Techniques and Methods Report TM-6E2, 115 p.

U.S. Geological Survey, variously dated, National Hydrography Dataset, accessed October 16, 2007, at ftp://nhdftp.usgs.gov/DataSets/Staged/SubRegions/ FileGDB/MediumResolution/.

U.S. Geological Survey EROS Data Center, 1999, 1 arc-second (30 meter) National Elevation Dataset: U.S. Geological Survey dataset, accessed September 15, 2008, at http://ned.usgs.gov/.

Utah Division of Water Rights, 2014: accessed July 12, 2014, at http://www.waterrights.utah.gov/cgi-bin/wuseview. exe?Startup.

Wahlquist, W.L., ed., 1981, Atlas of Utah: Provo, Utah, Brigham Young University Press, Provo, Utah.

Wallace, Janae, Thomas, Kevin, and Lowe, Mike, 2010, Evaluation of sources of poor quality ground water in the Bothwell Pocket area, Lower Bear River Valley, eastern Box Elder County, Utah: Utah Geological Survey Special Study 135, $51 \mathrm{p}$.

Welch, A.H., Bright, D.J., and Knochenmus, L.A., eds., 2007, Water resources of the Basin and Range carbonate-rock aquifer system, White Pine County, Nevada, and adjacent areas in Nevada and Utah: U.S. Geological Survey Scientific Investigations Report 2007-5261, 96 p., 4 pls., with downloadable appendix, available online at http://pubs.usgs.gov/sir/2007/5261/.

Western Regional Climate Center, 2012, Cooperative climatological data summaries: accessed July 15, 2012, at http://www.wrcc.dri.edu/summary/Climsmut.html. 


\section{Appendix 1. Miscellaneous Tables}

Table A1-1. Water levels in selected wells, March 1971 and March 2013, Malad-Lower Bear River study area.

This table is distributed as part of this report in Microsoft Excel 2010 format and is available for download at https://doi.org/10.3133/sir20175011.

Table A1-2. Mean crop acreage within individual irrigation areas, Malad-Lower Bear River study area.

This table is distributed as part of this report in Microsoft Excel 2010 format and is available for download at https://doi.org/10.3133/sir20175011.

Table A1-3. Average irrigated acreage, effective precipitation, and and representative crop consumptive use for irrigation areas, MaladLower Bear River study area.

This table is distributed as part of this report in Microsoft Excel 2010 format and is available for download at https://doi.org/10.3133/sir20175011.

Table A1-4. Discharge measurements of irrigation canals across State Highway 83, Malad-Lower Bear River study area.

This table is distributed as part of this report in Microsoft Excel 2010 format and is available for download at https://doi.org/10.3133/sir20175011.

Table A1-5. Tailwater from irrigation areas, Malad-Lower Bear River study area.

This table is distributed as part of this report in Microsoft Excel 2010 format and is available for download at https://doi.org/10.3133/sir20175011.

Table A1-6. Surface-water inflow, spring discharge, and surfacewater outflow used to estimate groundwater discharge as diffuse seepage, Malad-Lower Bear River study area.

This table is distributed as part of this report in Microsoft Excel 2010 format and is available for download at https://doi.org/10.3133/sir20175011.

Table A1-7. Miscellaneous discharge measurements of culverts and bridges across State Highway 83, Malad-Lower Bear River study area.

This table is distributed as part of this report in Microsoft Excel 2010 format and is available for download at https://doi.org/10.3133/sir20175011.
Table A1-8. Detailed description of groundwater discharge as evapotranspiration from groundwater discharge areas, Malad-Lower Bear River study area.

This table is distributed as part of this report in Microsoft Excel 2010 format and is available for download at https://doi.org/10.3133/sir20175011.

Table A1-9. Discharge from selected springs, ditches, and drains, Malad-Lower Bear River study area.

This table is distributed as part of this report in Microsoft Excel 2010 format and is available for download at https://doi.org/10.3133/sir20175011.

Table A1-10. Results of stable isotope analysis of water from selected springs, streams, and wells, Malad-Lower Bear River study area.

This table is distributed as part of this report in Microsoft Excel 2010 format and is available for download at https://doi.org/10.3133/sir20175011.

Table A1-11. Annual diversions to West Canal and East Hammond Canal, Malad-Lower Bear River study area.

This table is distributed as part of this report in Microsoft Excel 2010 format and is available for download at https://doi.org/10.3133/sir20175011. 


\section{Appendix 2. Seepage Assessments}

Seepage assessments were conducted to identify spatial and temporal patterns of net groundwater exchange to and from the Bear and Malad Rivers. Seepage assessments consisted of instantaneous stream discharge measurements made in downstream sequence under steady streamflow conditions. All identifiable surface-water inflows (springs, tributary streams, and overflows from irrigation canals) were also measured or estimated. Field drains that terminate within the river corridor are included as groundwater discharge to the river; drain discharge was not measured separately. Instantaneous river discharge was measured with acoustic Doppler current profilers (ADCP). During assessment of the Bear River, releases from Cutler Reservoir were held constant approximately 24 hours prior to and on the day of the measurement (fig. A2-1). The amount of net groundwater exchange is quantified using long-term (10 or more years) gaged streamflow records, and seasonal and spatial distribution of net groundwater exchange is estimated using the seepage assessments. Only for the ungaged reach of the Malad River (from Bear River Duck Club diversion to confluence with the Bear River) are seepage measurements used to quantify net exchange (table 5).

Seepage assessments on the Bear River in March 2012 and March 2013 did not identify a statistically significant groundwater gain or loss (tables A2-1 and A2-2). Whether there was net groundwater exchange (loss or gain) occurring between measurement locations cannot be determined with 95 percent confidence. Daily mean streamflow during the March 2012 and March 2013 assessments was 2,220 ft $3 / \mathrm{s}$ and 1,560 ft's, respectively, near Corinne (station 10126000). In September 2012, instantaneous discharge measurements indicated 47 $\mathrm{ft}^{3} / \mathrm{s}$ of gain between the Collinston (station 10118000) and Corinne streamflow gages. The September 2012 gain is about 55 percent of the long-term average difference after consideration of surface-water inflows (table 5) along the 39-mi river reach. The September 2012 assessment was used to spatially distribute the long-term gain along three sub-reaches (fig. A2-1).

Table A2-1. Discharge measurements of selected rivers, creeks, and canals, Malad-Lower Bear River study area.

This table is distributed as part of this report in Microsoft Excel 2010 format and is available for download at https://doi.org/10.3133/sir20175011.

Table A2-2. Calculations of groundwater discharge to selected rivers and creeks, Malad-Lower Bear River study area.

This table is distributed as part of this report in Microsoft Excel 2010 format and is available for download at https://doi.org/10.3133/sir20175011.
The seepage assessments conducted along the Malad River (fig. A2-1) identified quantifiable groundwater inflow with 95 percent confidence. In September 2012, about $27 \mathrm{ft}^{3} / \mathrm{s}$ $(18,000 \mathrm{acre}-\mathrm{ft} / \mathrm{yr})$ of groundwater discharged to the Malad River (table A2-2) from the Utah-Idaho state line to the Bear River Duck Club Canal diversion. Most of the discharge occurs along the reach between the inactive streamgage Malad River near Plymouth, Utah (station 10125600) and 1200 South at Tremonton, Utah (fig. A2-1). In February 2013, groundwater discharge for the same reach was about $9 \mathrm{ft}^{3} / \mathrm{s}$ (one-third of the summer amount). A seepage assessment in August 1971 (McGreevy, 1972) for the same reach of the Malad River had a measured gain of $29 \mathrm{ft}^{3} / \mathrm{s}$. During 1965-73, the difference between streamflow at Malad River near Plymouth (station 10125600) and the sum of streamflow at Bear River Duck Club Canal near Bear River City, Utah (10125700) and Malad River below Bear River Duck Club Canal near Bear River City, Utah (10125800) indicated a gain of $28 \mathrm{ft}^{3} / \mathrm{s}$. Given streamflow measurement uncertainty and variations in antecedent conditions, the gain along this section of the Malad River has remained relatively constant from the mid-1960s to 2010s. The upper end of the gaining reach coincides with the location where the Malad River enters areas of extensive surface-water irrigation. Both seasonal variation (more in summer, less in winter) and location of gain are consistent with irrigation as a source of groundwater recharge.

Seepage assessments conducted in August 1971, April 2013, and November 2013 quantified groundwater discharge to the Malad River reach from about $1 \mathrm{mi}$ below the Bear River Duck Club Canal diversion to the confluence with the Bear River. Gain for the reach was estimated to be $14 \mathrm{ft}^{3} / \mathrm{s}$ (table A2-2). 


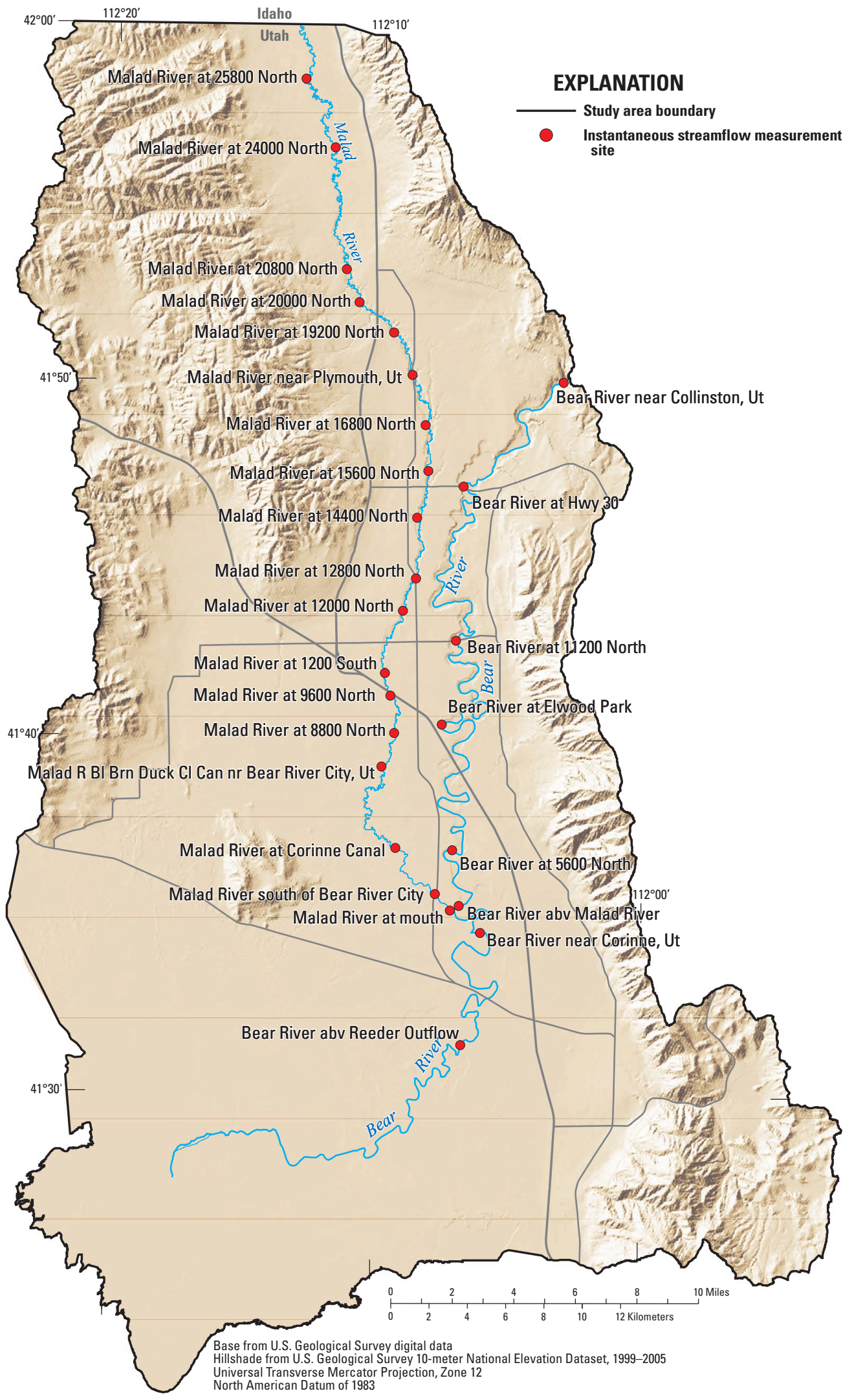

Figure A2-1. Location of seepage assessment measurements on the Bear and Malad Rivers, Malad-Lower Bear River study area. 


\section{Appendix 3. Observations and Error Analysis Used in the Numerical Groundwater Flow Model}

Table A3-1. Well data, water-level observation, observation variance, simulated values, and simulated residuals for observations of water levels in wells in selected areas of the GBCAAS v. 2.0 groundwater model, Malad-Lower Bear River study area and surrounding areas, Utah and Idaho.

This table is distributed as part of this report in Microsoft Excel 2010 format and is available for download at https://doi.org/10.3133/sir20175011.

Table A3-2. Model observations for discharge to Bear River, Malad River, and Sulphur Creek area in the HA273UTchild model, MaladLower Bear River study area.

This table is distributed as part of this report in Microsoft Excel 2010 format and is available for download at https://doi.org/10.3133/sir20175011.

Table A3-3. Model observations for discharge to selected springs, field drains, and evapotranspiration in the GBCAAS v. 2.0 groundwater model, Malad-Lower Bear River study area.

This table is distributed as part of this report in Microsoft Excel 2010 format and is available for download at https://doi.org/10.3133/sir20175011.
Table A3-4. Discharge of municipal springs and model observations in the GBCAAS v. 2.0 groundwater model, Malad-Lower Bear River study area.

This table is distributed as part of this report in Microsoft Excel 2010 format and is available for download at https://doi.org/10.3133/sir20175011.

Table A3-5. Selected springs not simulated explicitly in the GBCAAS v. 2.0 groundwater model, Malad-Lower Bear River study area.

This table is distributed as part of this report in Microsoft Excel 2010 format and is available for download at https://doi.org/10.3133/sir20175011.

Table A3-6. Simulated discharge at each discharge observation in the Great Salt Lake model region of the GBCAAS v. 2.0 groundwater model, Great Basin carbonate and alluvial aquifer system study area.

This table is distributed as part of this report in Microsoft Excel 2010 format and is available for download at https://doi.org/10.3133/sir20175011. 


\section{Appendix 4. Model Parameter Description, Statistics, and Distribution}

This appendix presents descriptions and distributions of model parameters in the HA273UTchild model and the surrounding area in the GBCAASv2parent model. Distributions of model parameters are shown in this appendix only if they have changed from GBCAAS v. 1.0 (Brooks and others, 2014). Parameter values and statistics are presented for all parameters in GBCAAS v. 2.0.

\section{Recharge}

In general, simulated equivalents to model observations of water levels and discharge (hereafter referred to as simulated values) in the HA273UTchild model are more sensitive to (provide more information about) recharge parameters than to any other parameters (fig. 31). This is similar to the results for GBCAAS v. 1.0 (Brooks and others, 2014, fig. 21). Parameters with high composite scaled sensitivity are important to simulated values and were divided into more parameters to represent those aspects of the system in more detail. As a result, 11 recharge parameters are included in the final HA273UTchild model (figs. 31, 32, A4-1, and table A4-1). The recharge parameter values are multipliers of the recharge multiplier arrays described in the "Recharge from Precipitation, Ephemeral Streams, and Irrigation" section of this report. During model calibration, parameter values and zones were changed, and parameters were combined and divided on the basis of composite scaled sensitivities and parameter confidence intervals. The zonation and parameter values result in substantially more in-place recharge than in GBCAAS v. 1.0 on the eastern mountains from Collinston to Brigham City, including the Cache Valley (HA 272) side of the mountains, slightly more recharge along the western edge of the HA273UTchild model (in HA 275), and the same in-place recharge in other areas. Final simulated recharge rates (the summation of the rates for each type of recharge multiplied by the parameter value) range from 0 to $4.53 \mathrm{ft} / \mathrm{yr}$ (fig. A4-2) in the HA273UTchild model.

Two new recharge parameters (rchrun2721 and rchrun2722, unitless multipliers of the recharge rate) have very high values (66.5 and 24.1) in the model. These occur because the multiplier array defining the rate of recharge from runoff (in ft/d) was changed to represent what are thought to be more accurate conditions (lower runoff in the study area than simulated in GBCAAS v. 1.0). Because the areas are outside of the study area, changing the amount of recharge and possible implications of that were beyond the scope of this study. The high parameter values were used, therefore, to maintain a similar rate of recharge as in GBCAAS v. 1.0. South of Collinston, Utah, the parameter was increased beyond that used in GBCAAS v. 1.0 to a value that was necessary to match spring discharge in the study area as estimated during this study; the parameter has a value larger than the reasonable limit of 2.25 (fig. 32). Two other recharge parameters (rch260 and rch275) have values above the reasonable limit of 2.25 (fig. 32). These parameters were in GBCAAS v. 1.0 and are in the GBCAASv2parent model, but only a small portion of the HA273UTchild model is represented by them.

One of the recharge parameters with a low value in GBCAAS v. 1.0 (rch9999; Brooks and others, 2014, p. 45) was also used in the child model to reduce recharge in areas where simulated water levels in layer 1 are above land surface. In some areas, the Basin Characterization Model (BCM) may overestimate the amount of recharge that enters the groundwater system because the surficial rock (used by BCM to calculate the amount of water that can infiltrate) may be more permeable than rock at the depth of the water table. In this case, infiltration may be horizontally diverted to streams and springs, or it may flow laterally to more permeable areas and then move down to the groundwater system. These processes would reduce the amount of recharge at the water table, and may explain some areas where simulated recharge needed to be reduced to cause lower water levels. In some areas, the need for this model parameter may be caused by the reduced cell size of the child model requiring a finer discretization of recharge rates, which was not done. This parameter is set at 0.01 (unitless multiplier of the recharge rate) and did not change during calibration (table A4-1).

As indicated by composite scaled sensitivities and linear confidence intervals, the simulated values provide enough information to constrain the estimates of recharge parameters within the HA273UTchild model more than the conceptual constraints (table 12). UCODE_2005 calculates a standard deviation of less than the estimated standard deviation (0.5) for 7 of the 11 parameters (table A4-1). For the other four parameters (table 13), prior information was used in UCODE_2005 to calculate the statistics presented in this report.

\section{Pumpage}

The simulated values provide little information about the parameter pumpage (fig. 31), which is a multiplier of the estimated withdrawal rate at each simulated well, but regression changed it from 1.0 to 0.995 . The model cannot constrain the value of the parameter with more certainty than the estimated uncertainty (table 12) and prior information (table 13) was used for this parameter to calculate the statistics presented in this report. 


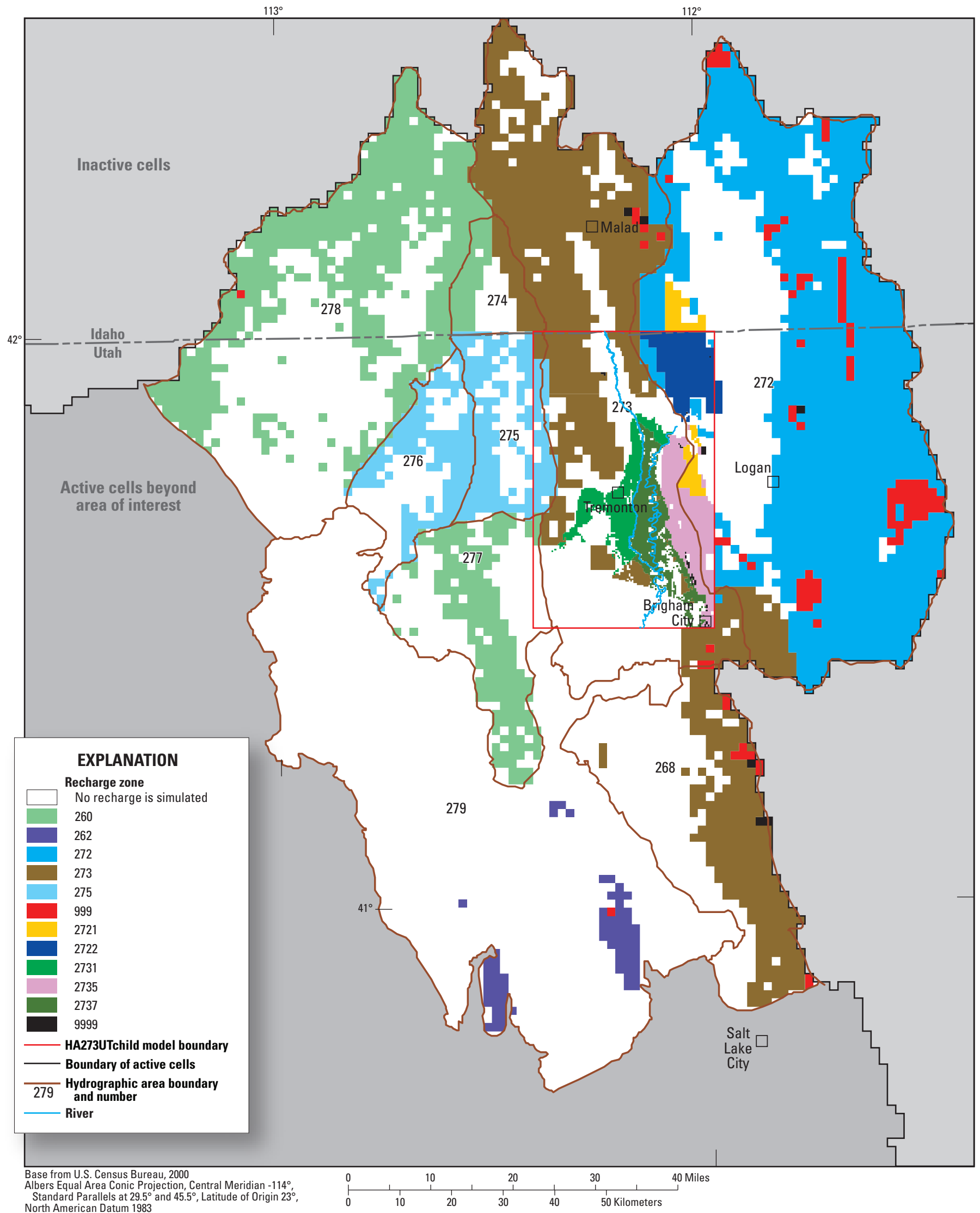

Figure A4-1. Model parameter distribution for recharge in the GBCAAS v. 2.0 groundwater model, Malad-Lower Bear River study area and surrounding areas, Utah and Idaho. 
Table A4-1. Model zones, multiplier arrays, and parameter values and statistics for recharge, pumpage, and lateral flow boundaries in the GBCAAS v. 2.0 groundwater model, Great Basin carbonate and alluvial aquifer system study area.

[Parameter value: multiplier of the conceptual recharge rate defined by the model multiplier arrays. 95-percent confidence interval: 95-percent linear confidence interval calculated by UCODE_2005 (Poeter and others, 2008, p. 174). Standard deviation: calculated by UCODE_2005 (Poeter and others, 2008).

Abbreviations: HA, hydrographic area; - , not applicable]

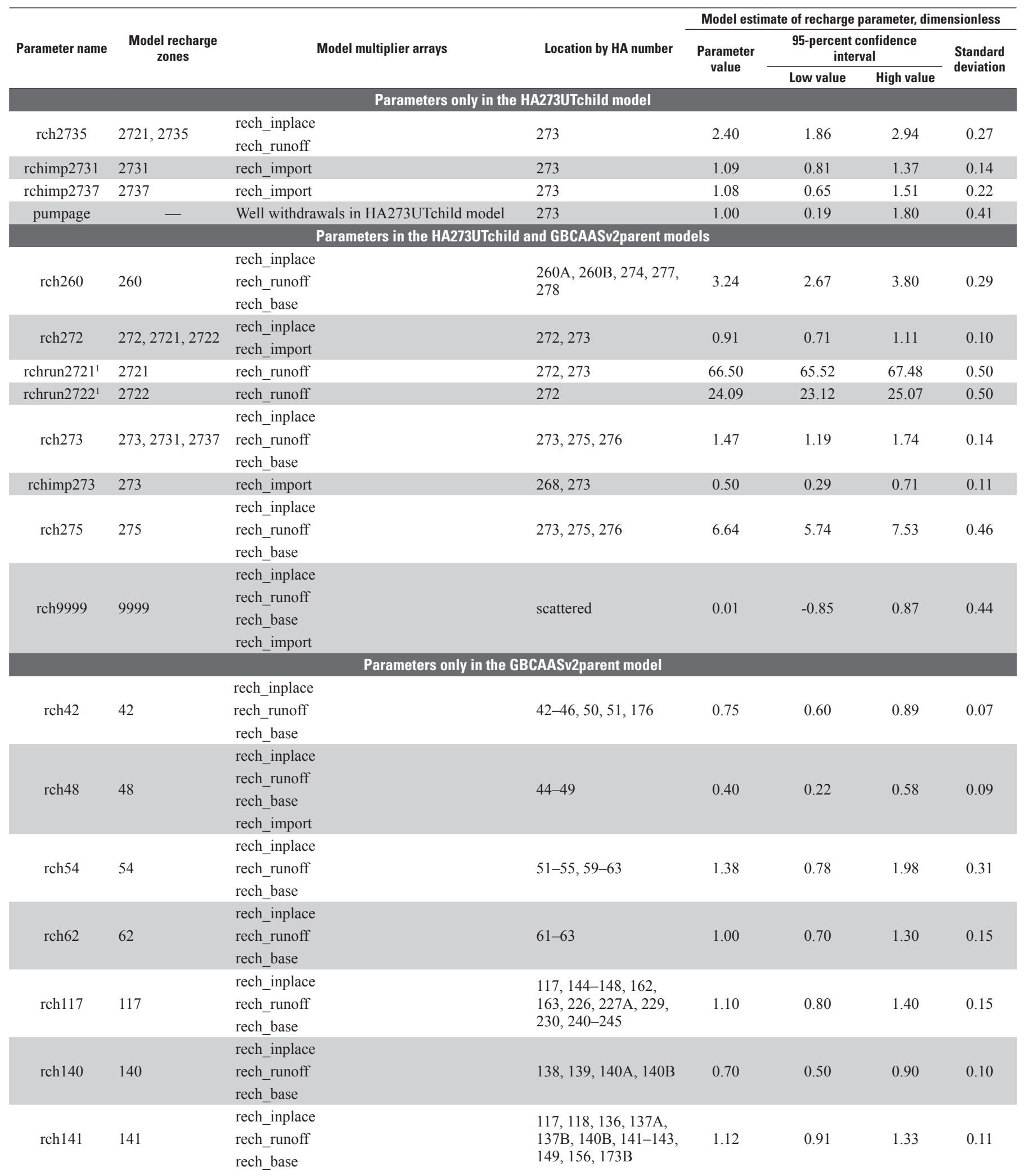


Table A4-1. Model zones, multiplier arrays, and parameter values and statistics for recharge, pumpage, and lateral flow boundaries in the GBCAAS v. 2.0 groundwater model, Great Basin carbonate and alluvial aquifer system study area.—Continued

[Parameter value: multiplier of the conceptual recharge rate defined by the model multiplier arrays. 95-percent confidence interval: 95-percent linear confidence interval calculated by UCODE_2005 (Poeter and others, 2008, p. 174). Standard deviation: calculated by UCODE_2005 (Poeter and others, 2008).

Abbreviations: HA, hydrographic area; - , not applicable]

\begin{tabular}{|c|c|c|c|c|c|c|c|}
\hline \multirow{3}{*}{ Parameter name } & \multirow{3}{*}{$\begin{array}{c}\text { Model recharge } \\
\text { zones }\end{array}$} & \multirow{3}{*}{ Model multiplier arrays } & \multirow{3}{*}{ Location by HA number } & \multicolumn{4}{|c|}{ Model estimate of recharge parameter, dimensionless } \\
\hline & & & & \multirow{2}{*}{$\begin{array}{l}\text { Parameter } \\
\text { value }\end{array}$} & \multicolumn{2}{|c|}{$\begin{array}{l}\text { 95-percent confidence } \\
\text { interval }\end{array}$} & \multirow{2}{*}{$\begin{array}{l}\text { Standard } \\
\text { deviation }\end{array}$} \\
\hline & & & & & Low value & High value & \\
\hline $\operatorname{rch} 144$ & 144 & $\begin{array}{l}\text { rech_inplace } \\
\text { rech_runoff } \\
\text { rech_base }\end{array}$ & $117,143,144,243$ & 0.60 & 0.34 & 0.86 & 0.13 \\
\hline $\operatorname{rch} 147$ & 147 & $\begin{array}{l}\text { rech_inplace } \\
\text { rech_runoff } \\
\text { rech_base }\end{array}$ & $147,157,227 \mathrm{~B}, 228$ & 0.13 & 0.02 & 0.24 & 0.06 \\
\hline $\operatorname{rch} 150$ & 150 & $\begin{array}{l}\text { rech_inplace } \\
\text { rech_runoff } \\
\text { rech_base }\end{array}$ & $\begin{array}{l}56,137 \mathrm{~B}, 150,155 \mathrm{~A} \\
155 \mathrm{~B}, 155 \mathrm{C}, 156 \\
173 \mathrm{~B}, 207\end{array}$ & 1.30 & 0.97 & 1.63 & 0.17 \\
\hline $\operatorname{rch} 154$ & 154 & $\begin{array}{l}\text { rech_inplace } \\
\text { rech_runoff } \\
\text { rech_base }\end{array}$ & $\begin{array}{l}139,151-154,155 \mathrm{~A}, \\
173 \mathrm{~B}, 174\end{array}$ & 0.85 & 0.62 & 1.07 & 0.12 \\
\hline $\operatorname{rch} 157$ & 157 & $\begin{array}{l}\text { rech_inplace } \\
\text { rech_runoff } \\
\text { rech_base }\end{array}$ & $\begin{array}{l}147,148,157,158 \mathrm{~A} \\
159,170,173 \mathrm{~A}, 227 \mathrm{~B} \\
228\end{array}$ & 0.37 & 0.25 & 0.50 & 0.06 \\
\hline $\operatorname{rch} 161$ & 161 & $\begin{array}{l}\text { rech_inplace } \\
\text { rech_runoff } \\
\text { rech_base }\end{array}$ & $\begin{array}{l}\text { 158B, 160-163, 168, } \\
169 \mathrm{~B}, 211,225\end{array}$ & 0.96 & 0.72 & 1.21 & 0.12 \\
\hline $\operatorname{rch} 172$ & 172 & $\begin{array}{l}\text { rech_inplace } \\
\text { rech_runoff } \\
\text { rech_base }\end{array}$ & $\begin{array}{l}158 \mathrm{~A}, 169 \mathrm{~A}, 170-172 \\
209\end{array}$ & 0.44 & 0.29 & 0.59 & 0.08 \\
\hline $\operatorname{rch} 175$ & 175 & $\begin{array}{l}\text { rech_inplace } \\
\text { rech_runoff } \\
\text { rech_base }\end{array}$ & $\begin{array}{l}47,174-177,178,187 \\
188,189 \mathrm{D}, 191,252 \\
261 \mathrm{~A}\end{array}$ & 0.58 & 0.46 & 0.69 & 0.06 \\
\hline $\operatorname{rch} 179$ & 179 & $\begin{array}{l}\text { rech_inplace } \\
\text { rech_runoff } \\
\text { rech_base }\end{array}$ & $179,184,207$ & 1.08 & 0.94 & 1.23 & 0.07 \\
\hline $\operatorname{rch} 180$ & 180 & $\begin{array}{l}\text { rech_inplace } \\
\text { rech_runoff } \\
\text { rech_base }\end{array}$ & 180,183 & 1.62 & 0.87 & 2.37 & 0.38 \\
\hline rch184 & 184 & $\begin{array}{l}\text { rech_inplace } \\
\text { rech_runoff } \\
\text { rech_base }\end{array}$ & $\begin{array}{l}178 \mathrm{~A}, 179,184,185 \\
186 \mathrm{~A}, 186 \mathrm{~B}, 253-257 \\
261 \mathrm{~A}, 284,287\end{array}$ & 0.90 & 0.74 & 1.06 & 0.08 \\
\hline rch189 & 189 & $\begin{array}{l}\text { rech_inplace } \\
\text { rech_runoff } \\
\text { rech_base }\end{array}$ & $\begin{array}{l}\text { 189A, 189B, 189C, } \\
189 \mathrm{D}\end{array}$ & 0.45 & 0.33 & 0.57 & 0.06 \\
\hline $\operatorname{rch} 202$ & 202 & $\begin{array}{l}\text { rech_inplace } \\
\text { rech_runoff } \\
\text { rech_base }\end{array}$ & $\begin{array}{l}171,181-183, \\
198-206,208-210, \\
216-221,254\end{array}$ & 0.19 & 0.16 & 0.23 & 0.02 \\
\hline $\operatorname{rch} 204$ & 204 & $\begin{array}{l}\text { rech_inplace } \\
\text { rech_runoff } \\
\text { rech_base }\end{array}$ & 204 & 0.40 & 0.18 & 0.62 & 0.11 \\
\hline $\operatorname{rch} 207$ & 207 & $\begin{array}{l}\text { rech_inplace } \\
\text { rech_runoff } \\
\text { rech_base }\end{array}$ & 180,207 & 1.40 & 0.90 & 1.89 & 0.25 \\
\hline $\operatorname{rch} 212$ & 212 & $\begin{array}{l}\text { rech_inplace } \\
\text { rech_runoff } \\
\text { rech_base }\end{array}$ & $\begin{array}{l}164 \mathrm{~A}, 164 \mathrm{~B}, 165-167 \\
212,215\end{array}$ & 0.99 & 0.75 & 1.23 & 0.12 \\
\hline
\end{tabular}


Table A4-1. Model zones, multiplier arrays, and parameter values and statistics for recharge, pumpage, and lateral flow boundaries in the GBCAAS v. 2.0 groundwater model, Great Basin carbonate and alluvial aquifer system study area.-Continued

[Parameter value: multiplier of the conceptual recharge rate defined by the model multiplier arrays. 95-percent confidence interval: 95-percent linear confidence interval calculated by UCODE_2005 (Poeter and others, 2008, p. 174). Standard deviation: calculated by UCODE_2005 (Poeter and others, 2008).

Abbreviations: HA, hydrographic area; - , not applicable]

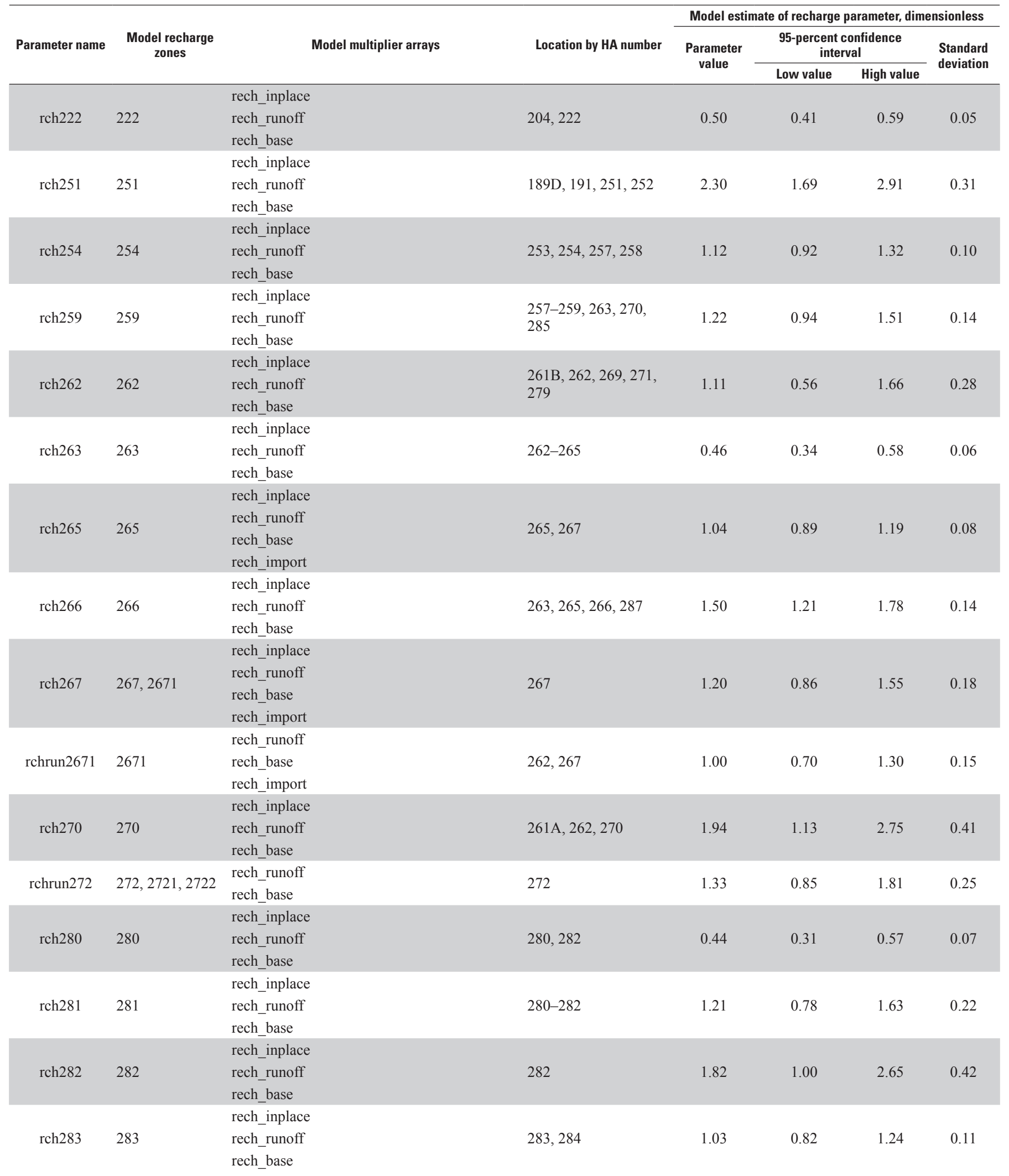


Table A4-1. Model zones, multiplier arrays, and parameter values and statistics for recharge, pumpage, and lateral flow boundaries in the GBCAAS v. 2.0 groundwater model, Great Basin carbonate and alluvial aquifer system study area.-Continued

[Parameter value: multiplier of the conceptual recharge rate defined by the model multiplier arrays. 95-percent confidence interval: 95-percent linear confidence interval calculated by UCODE_2005 (Poeter and others, 2008, p. 174). Standard deviation: calculated by UCODE_2005 (Poeter and others, 2008).

Abbreviations: HA, hydrographic area; - , not applicable]

\begin{tabular}{|c|c|c|c|c|c|c|c|}
\hline \multirow{3}{*}{ Parameter name } & \multirow{3}{*}{$\begin{array}{l}\text { Model recharge } \\
\text { zones }\end{array}$} & \multirow{3}{*}{ Model multiplier arrays } & \multirow{3}{*}{ Location by HA number } & \multicolumn{4}{|c|}{ Model estimate of recharge parameter, dimensionless } \\
\hline & & & & \multirow{2}{*}{$\begin{array}{l}\text { Parameter } \\
\text { value }\end{array}$} & \multicolumn{2}{|c|}{$\begin{array}{c}\text { 95-percent confidence } \\
\text { interval }\end{array}$} & \multirow{2}{*}{$\begin{array}{l}\text { Standard } \\
\text { deviation }\end{array}$} \\
\hline & & & & & Low value & High value & \\
\hline \multirow{3}{*}{$\operatorname{rch} 286$} & \multirow{3}{*}{286} & rech_runoff & \multirow{3}{*}{$283-287$} & \multirow{3}{*}{1.46} & \multirow{3}{*}{1.08} & \multirow{3}{*}{1.85} & \multirow{3}{*}{0.20} \\
\hline & & rech_base & & & & & \\
\hline & & rech_import & & & & & \\
\hline \multirow[t]{2}{*}{$\operatorname{rch} 364$} & \multirow[t]{2}{*}{364} & rech_runoff & \multirow[t]{2}{*}{ 164B, 245} & \multirow[t]{2}{*}{1.33} & \multirow[t]{2}{*}{0.89} & \multirow[t]{2}{*}{1.77} & \multirow[t]{2}{*}{0.23} \\
\hline & & rech_base & & & & & \\
\hline \multirow{4}{*}{ rch999 } & \multirow{4}{*}{999} & rech_inplace & \multirow{4}{*}{ scattered } & \multirow{4}{*}{0.10} & \multirow{4}{*}{-0.18} & \multirow{4}{*}{0.38} & \multirow{4}{*}{0.14} \\
\hline & & rech_runoff & & & & & \\
\hline & & rech_base & & & & & \\
\hline & & rech_import & & & & & \\
\hline
\end{tabular}

${ }^{1}$ Parameter value adjusted to keep same recharge within HA273UTchild model outside of the study area. The recharge from runoff multiplier was reduced to be more realistic at the smaller scale.

\section{Hydraulic Conductivity}

Horizontal hydraulic-conductivity parameters were assigned by using the zonation capability of the HUF Package (Anderman and Hill, 2000). Model zones are used to define areas with the same simulated properties within individual HGUs. Initially, the same zones and parameters used in GBCAAS v. 1.0 (Brooks and others, 2014) were used in GBCAAS v. 2.0. During calibration, however, it became apparent that this did not achieve adequate matches to observations in the Malad-Lower Bear River study area. Zone boundaries and parameters, therefore, were changed in the HA273UTchild model and in nearby areas of the GBCAASv2parent model. This is consistent with Sweetkind and others (2011, p. 19) that the original HGU zones are intended as a geologically based starting point for further refinement of horizontal hydraulic conductivity by the use of groundwater modeling. The delineation of these zones was mostly dependent on dimensionless scaled sensitivity and DFBETAS statistics representing the need to refine the zonation and define additional parameters.

A final set of 21 parameters define horizontal hydraulic conductivity in the HA273UTchild model (tables A4-2 to A4-4). Changes were made from GBCAAS v. 1.0 in the NCCU, LCAU, USCU, and UBFAU HGUs. The variability in simulated hydraulic conductivity is adequate to achieve calibration of this model but should not be considered accurate at a cell-by-cell level. The zone boundaries and parameter values may not be unique; different zonation and values could yield a model with approximately an equally good fit to model observations.
The parameter values and zones defining horizontal hydraulic conductivity of the NCCU in the HA273UTchild model were changed from GBCAAS v. 1.0 (figs. A4-3 and A4-4; Brooks and others, 2014, figs. 25 and A4-1) because of the change in recharge, because more discharge to springs was simulated, and because observed spring discharge was delineated into smaller areas than in GBCAAS v. 1.0. The representation of the NCCU across the child-parent boundary is mostly consistent (figs. A4-3 and A4-4). The parameter values and confidence intervals of all parameters defining horizontal hydraulic conductivity of the NCCU HGU in the HA273UTchild model are within reasonable ranges (table 11, fig. 32).

Parameters and zones defining horizontal hydraulic conductivity of the LCAU in the HA273UTchild model were changed significantly from GBCAAS v. 1.0 because of the changes in simulated recharge and a more detailed distribution of discharge to rivers and springs. Because of the extensive changes to the LCAU in the HA273UTchild model, the parameters are not consistent across the child-parent boundary (figs. A4-5 and A4-6). The values of all parameters defining horizontal hydraulic conductivity of the LCAU HGU in the HA273UTchild model are within reasonable ranges (table 11, fig. 32), but the lower confidence interval of parameter LCAU514hk is less than the lower reasonable range.

Parameters and zones representing the horizontal hydraulic conductivity of the USCU were changed very little. Most of the area is defined by the same zones and values as in GBCAAS v. 1.0, with the exception of zone USCU1 (value of 7.8 on fig. A4-7, table A4-2), which was given the same value of hydraulic conductivity as parameter LCAU611. This zone of higher conductivity was needed to prevent excessive drawdown from the irrigation wells in Bothwell Pocket (fig. 1) 


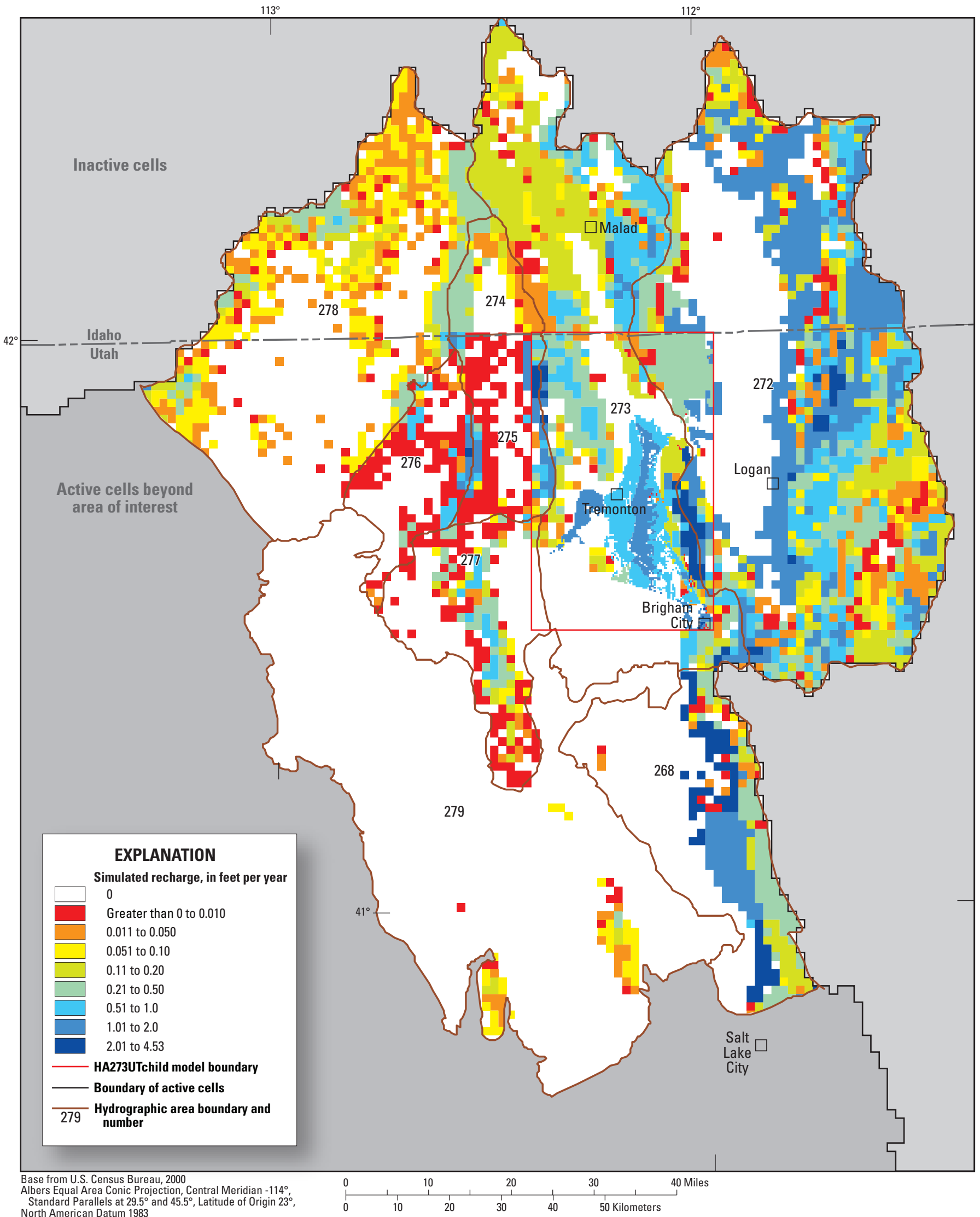

Figure A4-2. Distribution of simulated recharge in the GBCAAS v. 2.0 groundwater model, Malad-Lower Bear River study area and surrounding areas, Utah and Idaho. 
Table A4-2. Hydrogeologic zones, model zones, and parameter values and statistics for horizontal hydraulic conductivity of the confining units in the GBCAAS v. 2.0 groundwater model, Great Basin carbonate and alluvial aquifer system study area.

[Zone code: hydrogeologic zone from Sweetkind and others (2011a). Model zone: zone number used in MODFLOW files. 95-percent confidence interval: 95-percent linear confidence interval as calculated by UCODE_2005 (Poeter and others, 2008, p. 174). Standard deviation of log values: calculated by UCODE_2005 (Poeter and others, 2008). Abbreviations: HK, horizontal hydraulic conductivity; NCCU, non-carbonate confining unit; TNCCU, thrusted noncarbonate confining unit; USCU, upper siliciclastic confining unit]

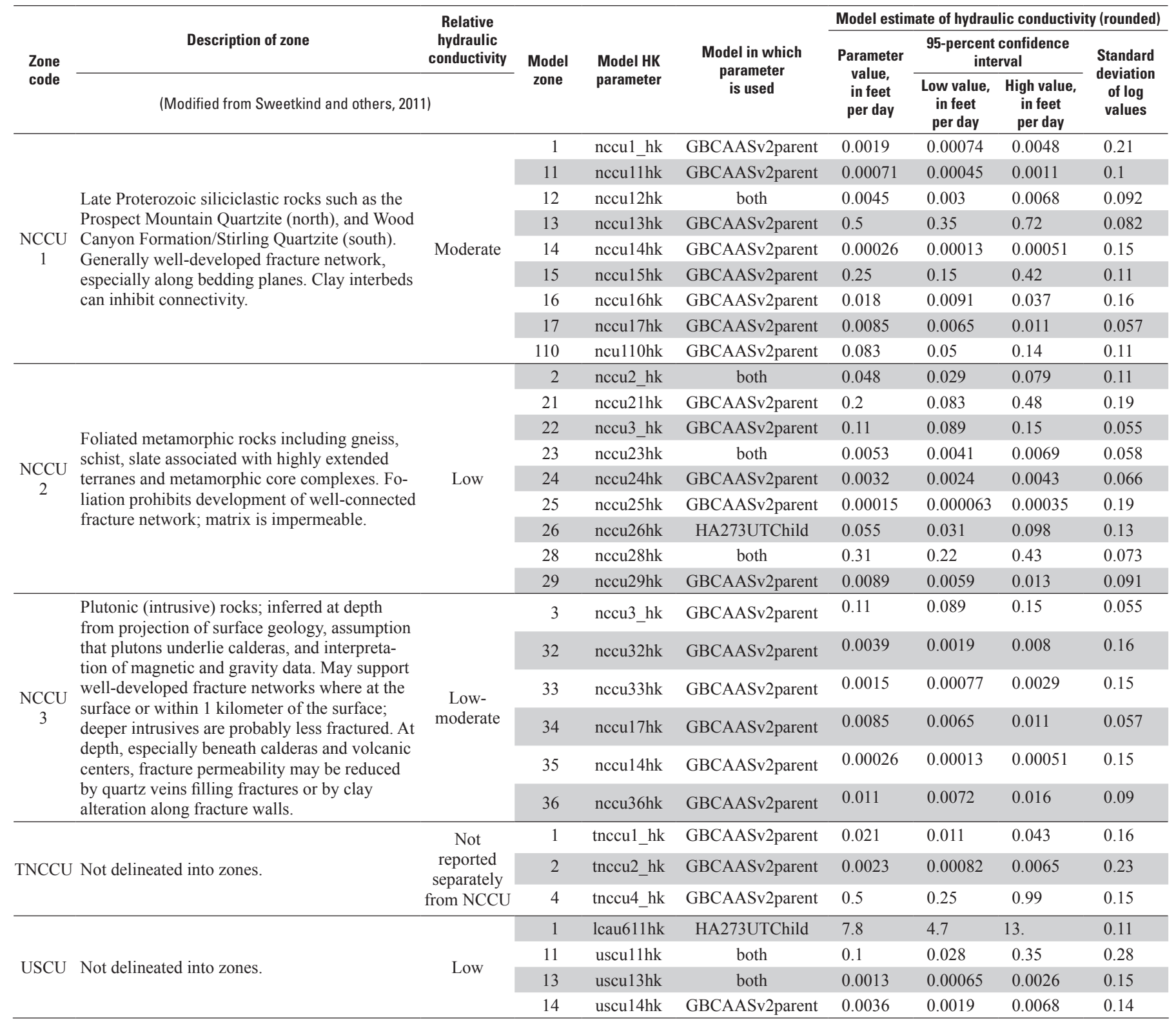


Table A4-3. Hydrogeologic zones, model zones, and parameter values and statistics for horizontal hydraulic conductivity of the carbonate aquifer units in the GBCAAS v. 2.0 groundwater model, Great Basin carbonate and alluvial aquifer system study area.

[Zone code: hydrogeologic zone from figure A4-2 and Sweetkind and others (2011a). Model zone: zone number used in MODFLOW files. 95-percent confidence interval: 95-percent linear confidence interval as calculated by UCODE 2005 (Poeter and others, 2008, p. 174). Standard deviation of log values: calculated by UCODE_2005 (Poeter and others, 2008). Abbreviations: HK, horizontal hydraulic conductivity; LCAU, lower carbonate aquifer unit; TLCAU, thrusted lower carbonate aquifer unit; UCAU, upper carbonate aquifer unit]

\begin{tabular}{|c|c|c|c|c|c|}
\hline \multirow{2}{*}{$\begin{array}{l}\text { Zone } \\
\text { code }\end{array}$} & Description of zone & $\begin{array}{c}\text { Relative } \\
\text { hydraulic } \\
\text { conductivity }\end{array}$ & \multirow{2}{*}{$\begin{array}{l}\text { Model } \\
\text { zone }\end{array}$} & \multirow{2}{*}{$\begin{array}{l}\text { Model HK } \\
\text { parameter }\end{array}$} & \multirow{2}{*}{$\begin{array}{l}\text { Model in which } \\
\text { parameter } \\
\text { is used }\end{array}$} \\
\hline & & & & & \\
\hline
\end{tabular}

LCAU Both lithology and structural factors enhance

81 hydraulic conductivity.

$\begin{array}{rrrrr} & 81 & \text { lcau81_hk } & \text { GBCAASv2parent } \\ \text { Highest } & 811 & \text { lcau811hk } & \text { GBCAASv2parent }\end{array}$

Model estimate of hydraulic conductivity (rounded)

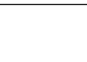

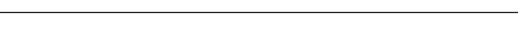

LCAU Both lithologic and structural factors enhance

61 hydraulic conductivity.

812 lcau812hk GBCAASv2parent

\begin{tabular}{|c|c|c|c|}
\hline \multirow{2}{*}{$\begin{array}{c}\text { Parameter } \\
\text { value, } \\
\text { in feet } \\
\text { per day }\end{array}$} & \multicolumn{2}{|c|}{$\begin{array}{l}\text { 95-percent confidence } \\
\text { interval }\end{array}$} & \multirow{2}{*}{$\begin{array}{c}\text { Standard } \\
\text { deviation } \\
\text { of log } \\
\text { values }\end{array}$} \\
\hline & $\begin{array}{l}\text { Low value, } \\
\text { in feet } \\
\text { per day }\end{array}$ & $\begin{array}{c}\text { High value, } \\
\text { in feet } \\
\text { per day }\end{array}$ & \\
\hline 4. & 3.3 & 4.9 & 0.043 \\
\hline 0.0095 & 0.0043 & 0.021 & 0.18 \\
\hline
\end{tabular}

$\begin{array}{rrr}812 & \text { lcau812hk } & \text { GBCAASv2parent } \\ 61 & \text { lcau61_hk } & \text { GBCAASv2parent }\end{array}$

2.5

$\begin{array}{ccc}611 & \text { lcau611hk } & \text { both } \\ 612 & \text { lcau612hk } & \text { GBCAASv2parent }\end{array}$

$1.3 \quad 4.7$

7.8

7.8
1.4

0.1

0.7

0.14

612 lcau612hk GBCAASv2parent

613 lcau613hk GBCAASv2parent

1.4
0.71

4.7
0.93

13.

614 lcau614hk GBCAASv2parent

0.065

$0.49 \quad 1$

2.1

61

616 lcau616hk

618 lcau618hk GBCAASv2parent

619 lcau619hk GBCAASv2parent

0.04

0.042

0.025

0.099

2.

1.2

0.063

3.4

0.011

0.026

10.

98.

51 lcau51_hk GBCAASv2parent

511 lcau511hk GBCAASv2parent

512 lcau512hk GBCAASv2parent

513 lcau513hk GBCAASv2parent

LCAU This is the "base case" for Great Basin

51 carbonates.

515

lcau515hk

GBCAASv2parent

516

517

51

5111

LCAU Very minor in western part of area.
63

63

lcau516hk

both

32.

10.

0.0064

0.97

98.

\section{5.}

0.0039

2.

9.924.

0.0011

0.00075

24.01

0.013

0.01

0.0017

$\begin{array}{ll}0.0017-0.092 \\ 0.016 & 0.05\end{array}$

Moderate

lcau517hk GBCAASv2parent

0.12

0.69

0.094

0.016

$\begin{array}{ll}0.094 & 0.16 \\ 0.51 & 0.92\end{array}$

6.6

lcau5111hk GBCAASv2parent

0.3

$3-5.5$

5.5

8.

0.22

0.4

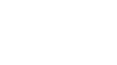

LCAU Extension may disrupt aquifer continuity.
41

Moderately
low

$\begin{array}{ccc}411 & \text { lcau43_hk } & \text { GBCAASv2parent } \\ 412 & \text { lcau412hk } & \text { GBCAASv2parent } \\ 413 & \text { lcau413hk } & \text { GBCAASv2parent } \\ 414 & \text { lcau414hk } & \text { GBCAASv2parent } \\ 415 & \text { lcau415hk } & \text { both }\end{array}$

0.02

0.0031

0.0076

0.0039

$\begin{array}{ll}0.0076 & 0.0039 \\ 0.0027 & 0.0018\end{array}$

$\begin{array}{lll} & 0.0027 & 0.00 \\ & 5.6 & 3 \\ & 0.6 & 0.48\end{array}$

0.36

$\begin{array}{lc}0.0018 & 0.0043 \\ 3 . & 11 . \\ 0.48 & 0.75\end{array}$

$\begin{array}{ccc}415 & \text { lcau415hk } & \text { both } \\ 416 & \text { lcau53_hk } & \text { GBCAASv2parent }\end{array}$

417 lcau417hk GBCAASv2parent

418 lcau418hk GBCAASv2parent

$\begin{array}{rll}52 & \text { lcau52_hk } & \text { GBCAASv2parent } \\ 521 & \text { lcau521hk } & \text { GBCAASv2parent }\end{array}$

LCAU Pilot Shale reduces hydraulic conductivity

52 below "base case."

Moderately 522 low

\begin{tabular}{rllllll}
\hline 522 & lcau522hk & GBCAASv2parent & 1.2 & 0.63 & 2.3 & 0.14 \\
\hline 523 & lcau523hk & GBCAASv2parent & 0.005 & 0.0025 & 0.0099 & 0.15 \\
\hline 524 & lcau524hk & GBCAASv2parent & 7. & 1.2 & 41. & 0.39 \\
\hline 525 & lcau525hk & GBCAASv2parent & 0.1 & 0.045 & 0.24 & 0.19 \\
\hline 53 & lcau53_hk & GBCAASv2parent & 2.5 & 1.8 & 3.3 & 0.066 \\
\hline 531 & lcau52_hk & GBCAASv2parent & 0.066 & 0.034 & 0.13 & 0.15 \\
\hline 532 & lcau414hk & GBCAASv2parent & 0.6 & 0.48 & 0.75 & 0.049 \\
\hline 533 & lcau418hk & GBCAASv2parent & 0.00075 & 0.00016 & 0.0036 & 0.35 \\
\hline 534 & lcau415hk & GBCAASv2parent & 0.36 & 0.3 & 0.44 & 0.043 \\
\hline 536 & lcau536hk & GBCAASv2parent & 0.02 & 0.0031 & 0.13 & 0.42 \\
\hline 42 & lcau42_hk & GBCAASv2parent & 1.2 & 0.68 & 2.3 & 0.13 \\
\hline 421 & lcau421hk & GBCAASv2parent & 0.027 & 0.014 & 0.053 & 0.15 \\
\hline 422 & lcau422hk & GBCAASv2parent & 0.07 & 0.025 & 0.19 & 0.23 \\
\hline 423 & lcau423hk & GBCAASv2parent & 0.18 & 0.078 & 0.42 & 0.19 \\
\hline
\end{tabular}

LCAU Both lithologic and structural factors reduce

42 hydraulic conductivity.

Low

$\begin{array}{ccc}422 & \text { lcau422hk } & \text { GBCAASv2parent } \\ 423 & \text { lcau423hk } & \text { GBCAASv2parent }\end{array}$

LCAU Thin bedded, silty carbonate reduces hydraulic Moderately

53 conductivity below "base case." low 
Table A4-3. Hydrogeologic zones, model zones, and parameter values and statistics for horizontal hydraulic conductivity of the carbonate aquifer units in the GBCAAS v. 2.0 groundwater model, Great Basin carbonate and alluvial aquifer system study area.-Continued

[Zone code: hydrogeologic zone from figure A4-2 and Sweetkind and others (2011a). Model zone: zone number used in MODFLOW files. 95-percent confidence interval: 95-percent linear confidence interval as calculated by UCODE_2005 (Poeter and others, 2008, p. 174). Standard deviation of log values: calculated by UCODE_2005 (Poeter and others, 2008). Abbreviations: HK, horizontal hydraulic conductivity; LCAU, lower carbonate aquifer unit; TLCAU, thrusted lower carbonate aquifer unit; UCAU, upper carbonate aquifer unit]

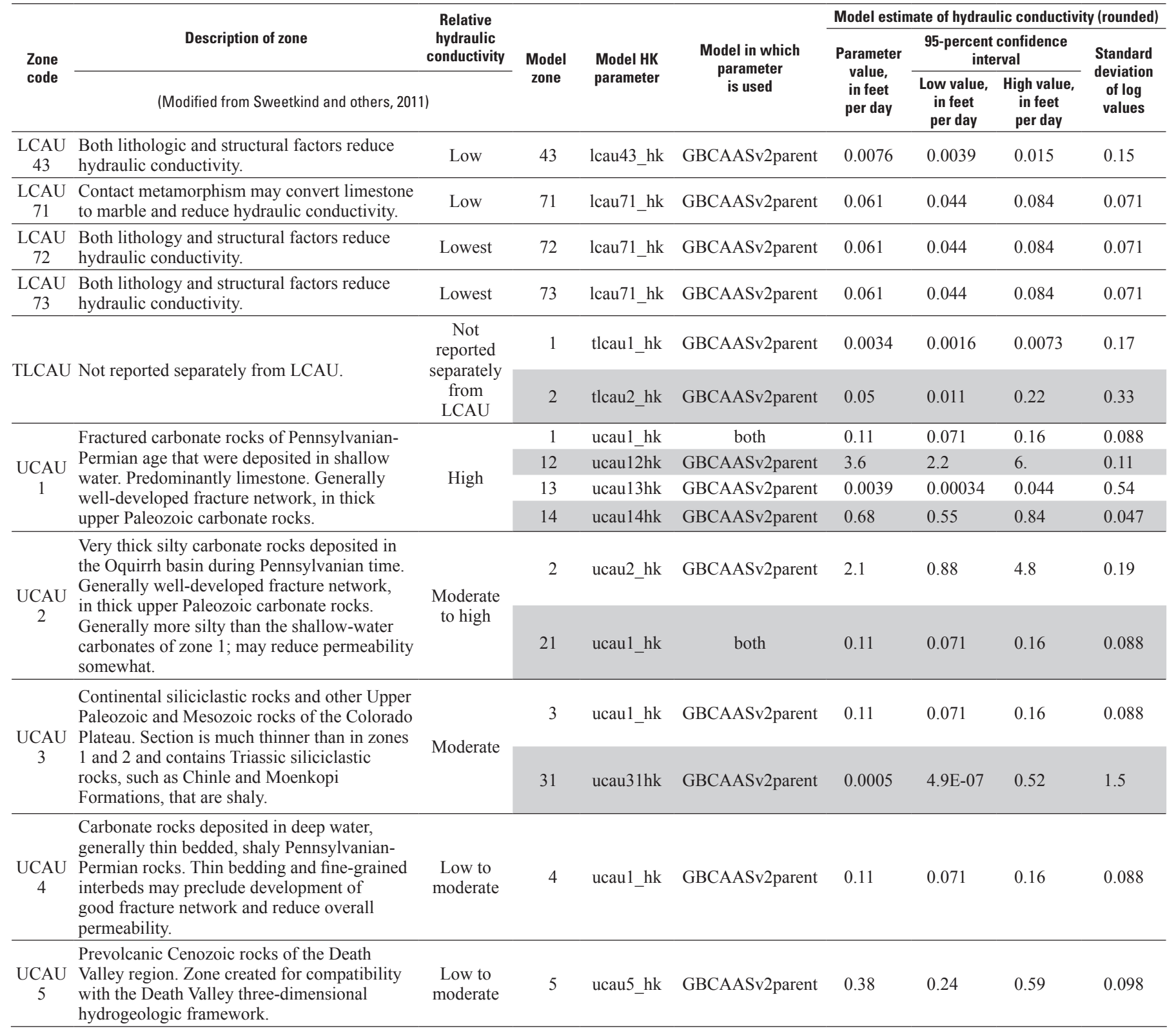


Table A4-4. Hydrogeologic zones, model zones, and parameter values and statistics for horizontal hydraulic conductivity of the volcanic and basin-fill units in the GBCAAS v. 2.0 groundwater model, Great Basin carbonate and alluvial aquifer system study area.

[Zone code: hydrogeologic zone from Sweetkind and others, 2011. Model zone: zone number used in MODFLOW files. 95-percent confidence interval: 95-percent linear confidence interval as calculated by UCODE_2005 (Poeter and others, 2008). Abbreviations: HK, horizontal hydraulic conductivity; VU, volcanic unit; LBFAU, lower basin-fill aquifer unit; UBFAU, upper basin-fill aquifer unit; —, not applicable]

\begin{tabular}{|c|c|c|c|c|c|c|c|c|c|}
\hline \multirow{3}{*}{$\begin{array}{l}\text { Zone } \\
\text { code }\end{array}$} & \multirow[b]{2}{*}{ Description of zone } & \multirow{3}{*}{$\begin{array}{c}\text { Relative } \\
\text { hydraulic } \\
\text { conductivity }\end{array}$} & \multirow{3}{*}{$\begin{array}{l}\text { Model } \\
\text { zone }\end{array}$} & \multirow{3}{*}{$\begin{array}{l}\text { Model HK } \\
\text { parameter }\end{array}$} & \multirow{3}{*}{$\begin{array}{l}\text { Model in which } \\
\text { parameter } \\
\text { is used }\end{array}$} & \multicolumn{4}{|c|}{ Model estimate of hydraulic conductivity (rounded) } \\
\hline & & & & & & \multirow{2}{*}{$\begin{array}{l}\text { Parameter } \\
\text { value, } \\
\text { in feet } \\
\text { per day }\end{array}$} & \multicolumn{2}{|c|}{$\begin{array}{l}\text { 95-percent confidence } \\
\text { interval }\end{array}$} & \multirow{2}{*}{$\begin{array}{c}\text { Standard } \\
\text { deviation } \\
\text { of log } \\
\text { values }\end{array}$} \\
\hline & (Modified from Sweetkind and others, 2011) & & & & & & $\begin{array}{l}\text { Low value, } \\
\text { in feet } \\
\text { per day }\end{array}$ & $\begin{array}{c}\text { High value, } \\
\text { in feet } \\
\text { per day }\end{array}$ & \\
\hline \multirow[b]{2}{*}{ VU 1} & \multirow{2}{*}{$\begin{array}{l}\text { Welded ash-flow tuff, generally in thick } \\
\text { sequences. Generally well-developed fracture } \\
\text { network. Permeability may be reduced } \\
\text { somewhat inside calderas due to lithologic } \\
\text { heterogeneity. }\end{array}$} & \multirow[b]{2}{*}{ High } & 1 & vul_hk & GBCAASv2parent & 0.47 & 0.38 & 0.6 & 0.052 \\
\hline & & & $\begin{array}{r}12 \\
120\end{array}$ & vu2_hk & $\begin{array}{l}\text { GBCAASv2parent } \\
\text { GBCAASv2parent }\end{array}$ & 0.0034 & 0.0017 & 0.0066 & 0.15 \\
\hline \multirow[b]{2}{*}{ VU 2} & \multirow{2}{*}{$\begin{array}{l}\text { Local lava flows; areas of rhyolite to andesite } \\
\text { lava flows that form localized accumulations, } \\
\text { not widespread sheets. Can be highly fractured, } \\
\text { but fracture pattern is typically disorganized } \\
\text { and fractures are short. }\end{array}$} & \multirow[b]{2}{*}{$\begin{array}{l}\text { Moderate to } \\
\text { high }\end{array}$} & 2 & vu2_hk & GBCAASv2parent & 0.0034 & 0.0017 & 0.0066 & 0.15 \\
\hline & & & 22 & vu22hk & GBCAASv2parent & 1.6 & 0.81 & 3.1 & 0.15 \\
\hline \multirow{2}{*}{ VU 3} & \multirow{2}{*}{$\begin{array}{l}\text { Prevolcanic basins; areas where significant } \\
\text { amounts of sedimentary rocks may underlie } \\
\text { outcrops of volcanic rocks. Consists of early } \\
\text { Cenozoic lake beds and generally fine-grained } \\
\text { deposits; can include some sandy or coarse- } \\
\text { grained material. }\end{array}$} & \multirow{2}{*}{ Moderate } & 3 & vul_hk & GBCAASv2parent & 0.47 & 0.38 & 0.6 & 0.052 \\
\hline & & & 31 & vu5_hk & GBCAASv2parent & 0.083 & 0.06 & 0.11 & 0.07 \\
\hline VU 4 & Shallow or outcropping basalt. & Moderate & 4 & vul_hk & GBCAASv2parent & 0.47 & 0.38 & 0.6 & 0.052 \\
\hline VU 5 & Mesozoic and Cenozoic sedimentary rocks. & $\begin{array}{l}\text { Low to } \\
\text { moderate }\end{array}$ & & & GBCAASv2parent & & & & \\
\hline VU 6 & $\begin{array}{l}\text { Heterogenous rocks, includes tuff, rhyolite to } \\
\text { basalt lava flows, and interbedded sedimentary } \\
\text { rocks. Heterogeneity may reduce overall } \\
\text { permeability. }\end{array}$ & $\begin{array}{l}\text { Low to } \\
\text { moderate }\end{array}$ & 5 & vu5_hk & GBCAASv2parent & 0.083 & 0.06 & 0.11 & 0.07 \\
\hline \multirow{3}{*}{ VU 7} & \multirow{3}{*}{$\begin{array}{l}\text { Intracaldera ash-flow tuff and other rocks } \\
\text { related to caldera collapse. Permeability of } \\
\text { volcanic rocks may be reduced inside calderas. } \\
\text { Unit has the potential to be hydrothermally } \\
\text { altered. }\end{array}$} & \multirow{3}{*}{$\begin{array}{l}\text { Moderate, } \\
\text { variable }\end{array}$} & 7 & vu2_hk & GBCAASv2parent & 0.0034 & 0.0017 & 0.0066 & 0.15 \\
\hline & & & 71 & vul_hk & GBCAASv2parent & 0.47 & 0.38 & 0.6 & 0.052 \\
\hline & & & 76 & vu5_hk & GBCAASv2parent & 0.083 & 0.06 & 0.11 & 0.07 \\
\hline $\begin{array}{l}\text { LBFAU } \\
1 \\
1 \\
\end{array}$ & $\begin{array}{l}\text { Welded ash-flow tuff; thick sequences that fill } \\
\text { the bottoms of Cenozoic basins within and } \\
\text { surrounding volcanic fields. Generally well- } \\
\text { developed fracture network. Permeability may } \\
\text { be reduced somewhat inside calderas due to } \\
\text { lithologic heterogeneity. }\end{array}$ & High & 1 & lbfau1_hk & GBCAASv2parent & 0.042 & 0.0074 & 0.24 & 0.38 \\
\hline \multirow{3}{*}{$\begin{array}{l}\text { LBFAU } \\
2\end{array}$} & \multirow{3}{*}{$\begin{array}{l}\text { Intracaldera ash-flow tuff and other rocks, } \\
\text { where calderas extend from mountain ranges } \\
\text { into intervening valleys. Permeability of } \\
\text { volcanic rocks may be reduced inside calderas. } \\
\text { Unit has the potential to be hydrothermally } \\
\text { altered. }\end{array}$} & \multirow{3}{*}{$\begin{array}{l}\text { Moderate, } \\
\text { variable }\end{array}$} & 2 & vu2_hk & GBCAASv2parent & 0.0034 & 0.0017 & 0.0066 & 0.15 \\
\hline & & & 23 & vul_hk & GBCAASv2parent & 0.47 & 0.38 & 0.6 & 0.052 \\
\hline & & & 26 & vu5_hk & GBCAASv2parent & 0.083 & 0.06 & 0.11 & 0.07 \\
\hline $\begin{array}{l}\text { LBFAU } \\
3 \\
\end{array}$ & $\begin{array}{l}\text { Local lava flows; areas of more localized lava } \\
\text { flows, generally andesite or rhyolite, that fill } \\
\text { the bottoms of Cenozoic basins within and } \\
\text { surrounding volcanic centers. Can be highly } \\
\text { fractured, but fracture pattern is typically } \\
\text { disorganized and fractures are short. }\end{array}$ & $\begin{array}{l}\text { Moderate to } \\
\text { high }\end{array}$ & 3 & lbfau3_hk & GBCAASv2parent & 0.5 & 0.14 & 1.8 & 0.29 \\
\hline $\begin{array}{l}\text { LBFAU } \\
4 \\
4\end{array}$ & $\begin{array}{l}\text { Prevolcanic Cenozoic sedimentary rocks; } \\
\text { generally lake-bed and other fine-grained } \\
\text { deposits, but can include some sandy or coarse- } \\
\text { grained material. }\end{array}$ & Moderate & 4 & lbfau4_hk & both & 0.3 & 0.093 & 0.97 & 0.26 \\
\hline $\begin{array}{l}\text { LBFAU } \\
5 \\
\end{array}$ & $\begin{array}{l}\text { Generally coarse-grained basin fill. Deep burial } \\
\text { and cementation may reduce permeability. }\end{array}$ & Moderate & $\begin{array}{r}5 \\
501 \\
\end{array}$ & lbfau5_hk & $\begin{array}{l}\text { both } \\
\text { both }\end{array}$ & 0.23 & 0.1 & 0.51 & 0.18 \\
\hline $\begin{array}{l}\text { LBFAU } \\
99\end{array}$ & Defined only for model & - & 99 & ucaul_hk & GBCAASv2parent & 0.11 & 0.071 & 0.16 & 0.088 \\
\hline
\end{tabular}


Table A4-4. Hydrogeologic zones, model zones, and parameter values and statistics for horizontal hydraulic conductivity of the volcanic and basin-fill units in the GBCAAS v. 2.0 groundwater model, Great Basin carbonate and alluvial aquifer system study area.-Continued

[Zone code: hydrogeologic zone from Sweetkind and others, 2011. Model zone: zone number used in MODFLOW files. 95-percent confidence interval: 95-percent linear confidence interval as calculated by UCODE_2005 (Poeter and others, 2008). Abbreviations: HK, horizontal hydraulic conductivity; VU, volcanic unit; LBFAU, lower basin-fill aquifer unit; UBFAU, upper basin-fill aquifer unit; —, not applicable]

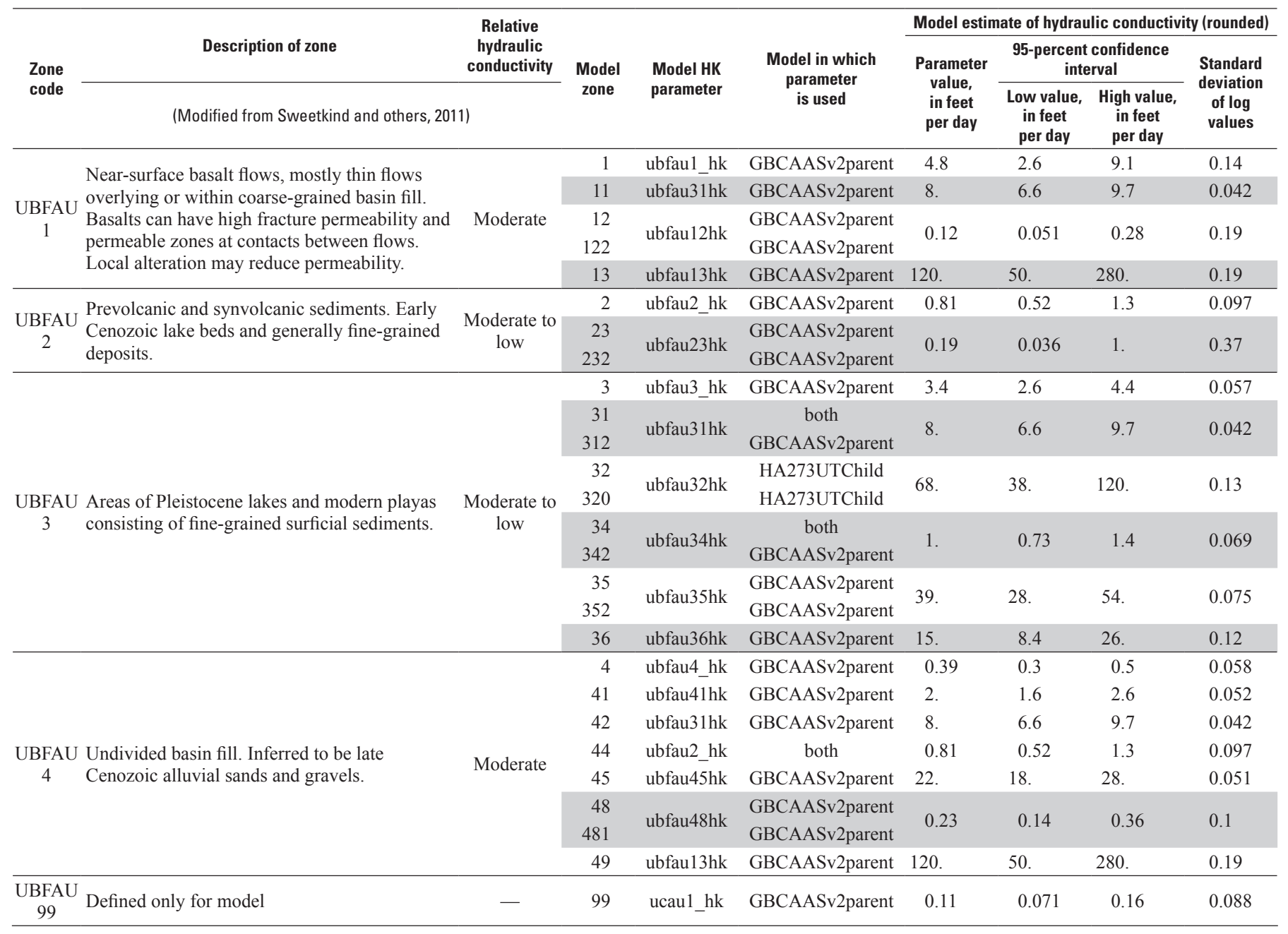




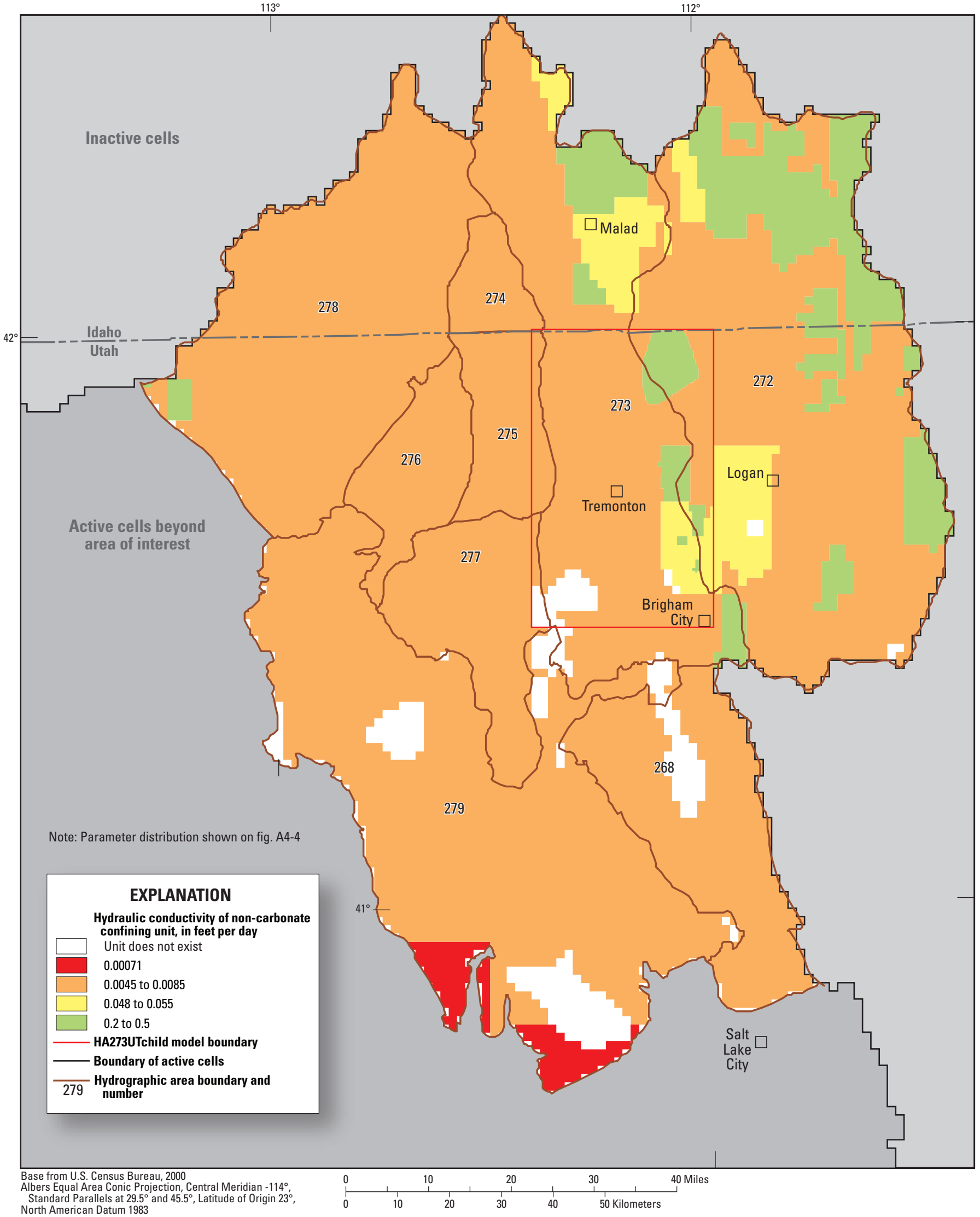

Figure A4-3. Distribution of hydraulic conductivity of the non-carbonate confining unit (NCCU) in the GBCAAS v. 2.0 groundwater model, Malad-Lower Bear River study area and surrounding areas, Utah and Idaho. 


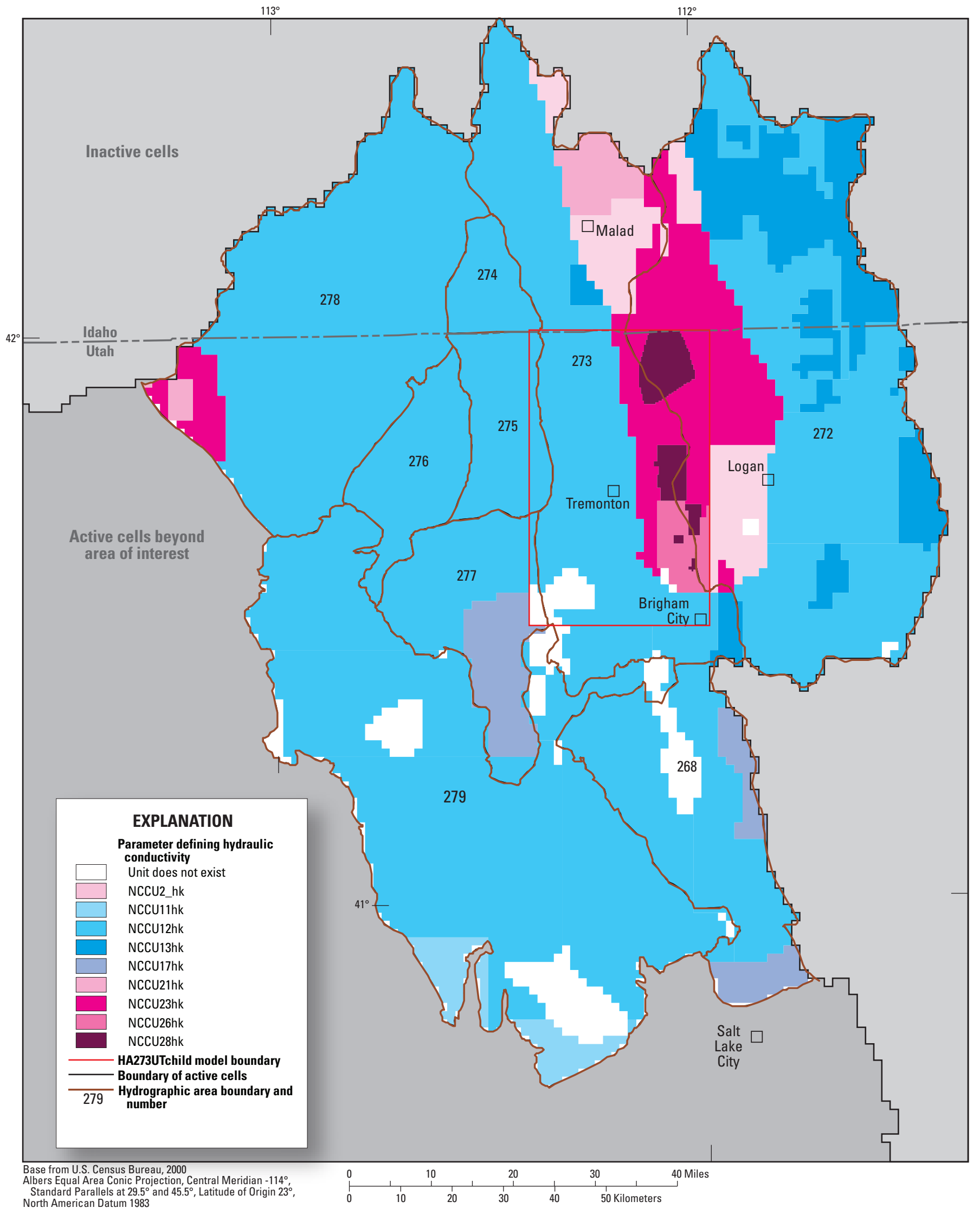

Standard Parallels at $29.5^{\circ}$ and $45.5^{\circ}$, Latitude of Origin $23^{\circ}$

Figure A4-4. Distribution of model parameters defining hydraulic conductivity of the non-carbonate confining unit (NCCU) in the GBCAAS v. 2.0 groundwater model, Malad-Lower Bear River study area and surrounding areas, Utah and Idaho. 


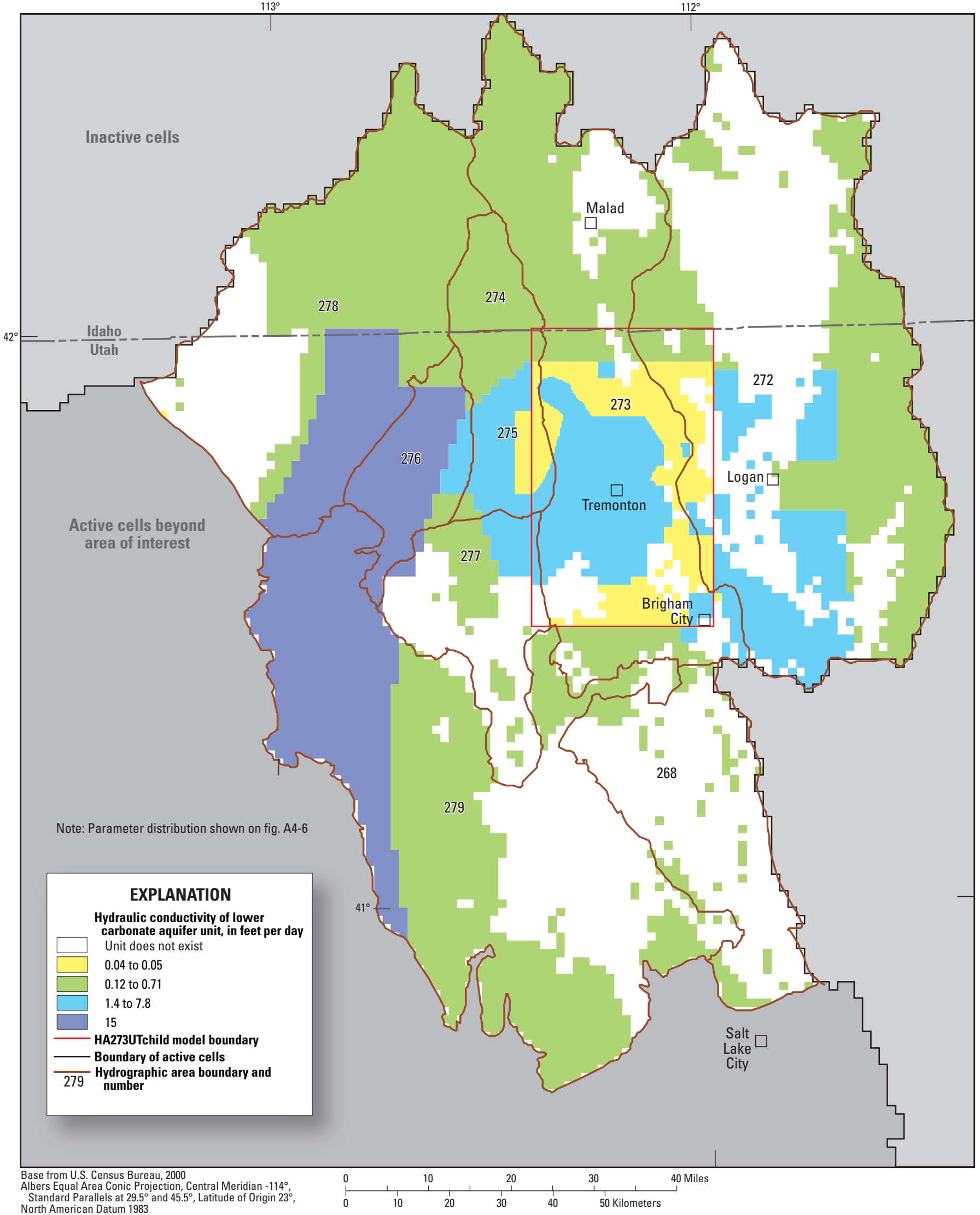

Figure A4-5. Distribution of hydraulic conductivity of the lower carbonate aquifer unit (LCAU) in the GBCAAS v. 2.0 groundwater model, Malad-Lower Bear River study area and surrounding areas, Utah and Idaho. 


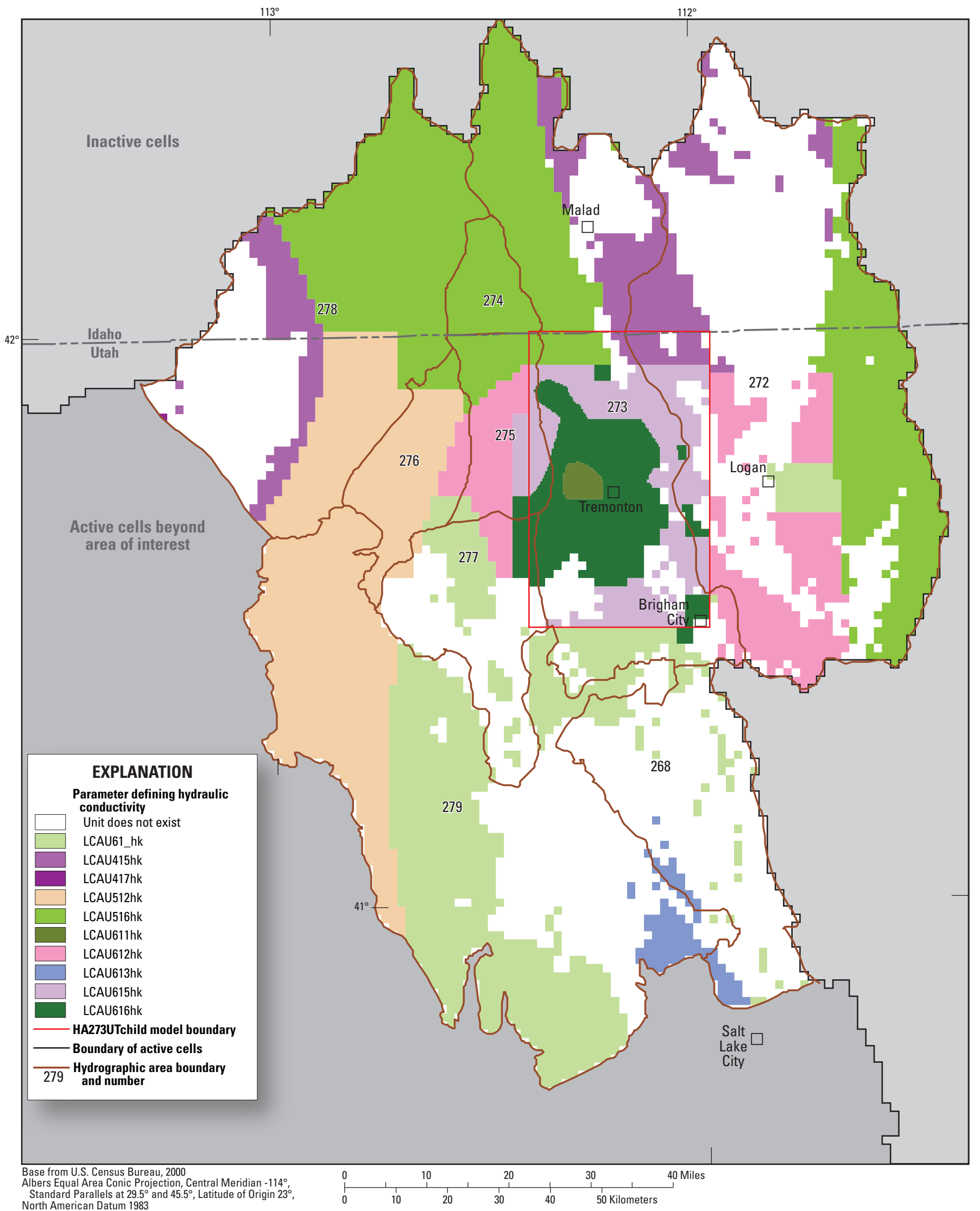

Figure A4-6. Distribution of model parameters defining hydraulic conductivity of the lower carbonate aquifer unit (LCAU) in the GBCAAS v. 2.0 groundwater model, Malad-Lower Bear River study area and surrounding areas, Utah and Idaho. 


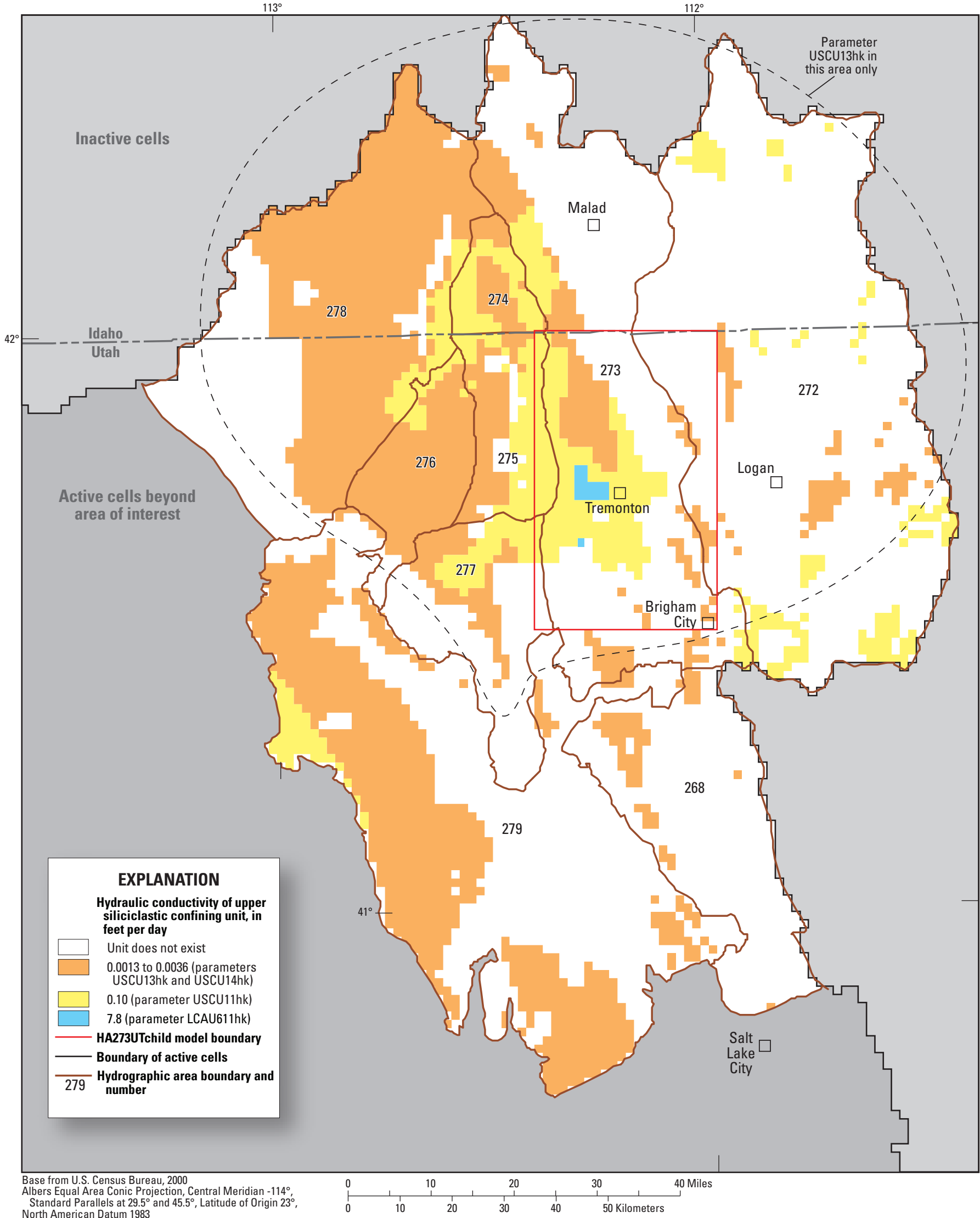

Figure A4-7. Distribution of hydraulic conductivity of the upper siliciclastic confining unit (USCU) in the GBCAAS v. 2.0 groundwater model, Malad-Lower Bear River study area and surrounding areas, Utah and Idaho. 
and to allow water to discharge at springs around Jesse's Knoll (S273Jesse; fig. 27, table A3-3). Water levels measured by the USGS show little long-term change in the Bothwell area (fig. 5), despite seasonal groundwater withdrawals. Wallace and others (2010, p. 13) report that water levels in wells generally showed little change between seasons. It is possible that the regional-scale hydrogeologic framework (Sweetkind and others, 2011) does not adequately portray the location or thickness of USCU in this location. Wallace and others (2010, p. 13) discuss two wells that penetrated alluvial material, were completed in limestone, and that indicate a transmissivity of $207,000 \mathrm{ft}^{2} / \mathrm{d}$. Because this zone was only added in the interior of the HA273UTchild model, the parameters defining hydraulic conductivity of the USCU are consistent across the child-parent boundary (fig. A4-7). The parameter values and confidence intervals of the parameters defining horizontal hydraulic conductivity of the USCU HGU in the HA273UTchild model are within reasonable ranges for either the USCU or the LCAU HGUs (table 11, fig. 32).

Parameters and zones describing the hydraulic conductivity of the UBFAU were changed extensively (figs. A4-8 and A4-9; Brooks and others, 2014, figs. 33 and A4-5). The simulated values of discharge to springs and rivers are sensitive to these parameters, and as a group, these parameters have higher composite scaled sensitivity in the HA273UTchild model than any other parameter group except recharge (fig. 31). Because of the extensive changes to the UBFAU in the HA273UTchild model, the hydraulic conductivity of the UBFAU is not consistent across the child-parent boundary (figs. A4-8 and A4-9). The parameter values and confidence intervals of all parameters defining horizontal hydraulic conductivity of the UBFAU HGU in the HA273UTchild model are within reasonable ranges (table 11, fig. 32).

\section{Vertical Anisotropy}

Simulated values in the HA273UTchild model are not very sensitive to vertical anisotropy (fig. 31) and the vertical anisotropy of all HGUs below the UBFAU was not changed from GBCAAS v. 1.0. This leaves much of the LBFAU simulated with a vertical anisotropy of 66 (parameter playa_vn, horizontal-to-vertical ratio, table A4-5). Vertical anisotropy in the UBFAU was generally decreased in the HA273UTchild model (fig. A4-10) compared to GBCAAS v. 1.0, and mostly has an anisotropy of 66 (parameter playa_vn) instead of 987 (parameter playa $2 \mathrm{vn}$ ). The value of 66 is reasonable given the heterogeneity of the basin fill and presence of clay as explained in the "Hydrogeology" section of this report. Although the composite scaled sensitivity of anisotropy is small (fig. 31), changing the value by an order of magnitude by using anisotropy parameters that are used nearby in the GBCAASv2parent model causes large differences in the simulated discharge at some locations (table A4-6). The representation of vertical anisotropy is consistent across the child-parent boundary (fig. A4-10). All values and confidence intervals for anisotropy parameters in the HA273UTchild model are within reasonable ranges (tables 12 and A4-5, fig. 32).

\section{Drain and River Conductance}

Drain conductance is used in the simulation of springs, field drains, and ETg in this model. The simulated values of discharge to springs and field drains are not very sensitive to drain conductance (fig. 31) and the parameter (discharge) representing springs and field drains is the same as in GBCAAS v. 1.0. The simulated values of discharge to ETg are sensitive to the parameter representing drain conductance for ETg (fig. 31), and the value was reduced from 2.5 to 1.3 (changed parameter from et_gslnorth to et272, fig. A4-11). Regression of the model yielded a lower value of river conductance within the HA273UTchild model than was used in GBCAAS v. 1.0 in other areas. River conductance was not used in the study area in GBCAAS v. 1.0 because the previous water budget (Bjorklund and McGreevy, 1974) did not provide enough detail to separate discharge to rivers from other forms of discharge. The values of all parameters describing the conductance of discharge boundaries in the HA273UTchild model are within reasonable limits; the upper confidence interval of parameter et 272 is slightly larger than the reasonable limit (fig. 32, tables 12 and A4-7). The simulated rate of ETg ranges from 0 to $6.53 \mathrm{ft} / \mathrm{yr}$ in the HA273UTchild model (fig. A4-12).

\section{Horizontal-Flow Barriers}

Simulated values provide little information about the conductance of HFBs (fig. 31); composite scaled sensitivity of HFB parameters may be low because of their small value (Hill and Tiedeman, 2007, p. 43). The same parameter (b_hfb1) used for the study area in GBCAAS v. 1.0 is used in the HA273UTchild model (table A4-8) to cause simulated values to match observed values of water levels and discharge. The value and confidence interval of the parameter used in the HA273UTchild model are within the reasonable range (fig. 32, table 12). The simulated values provide enough information to constrain the estimates of the parameters to within smaller ranges than the conceptual constraints. The standard deviation calculated by UCODE_2005 is less than the observed standard deviation of 2.7 for the log values of the parameters (tables 12 and A4-8). 


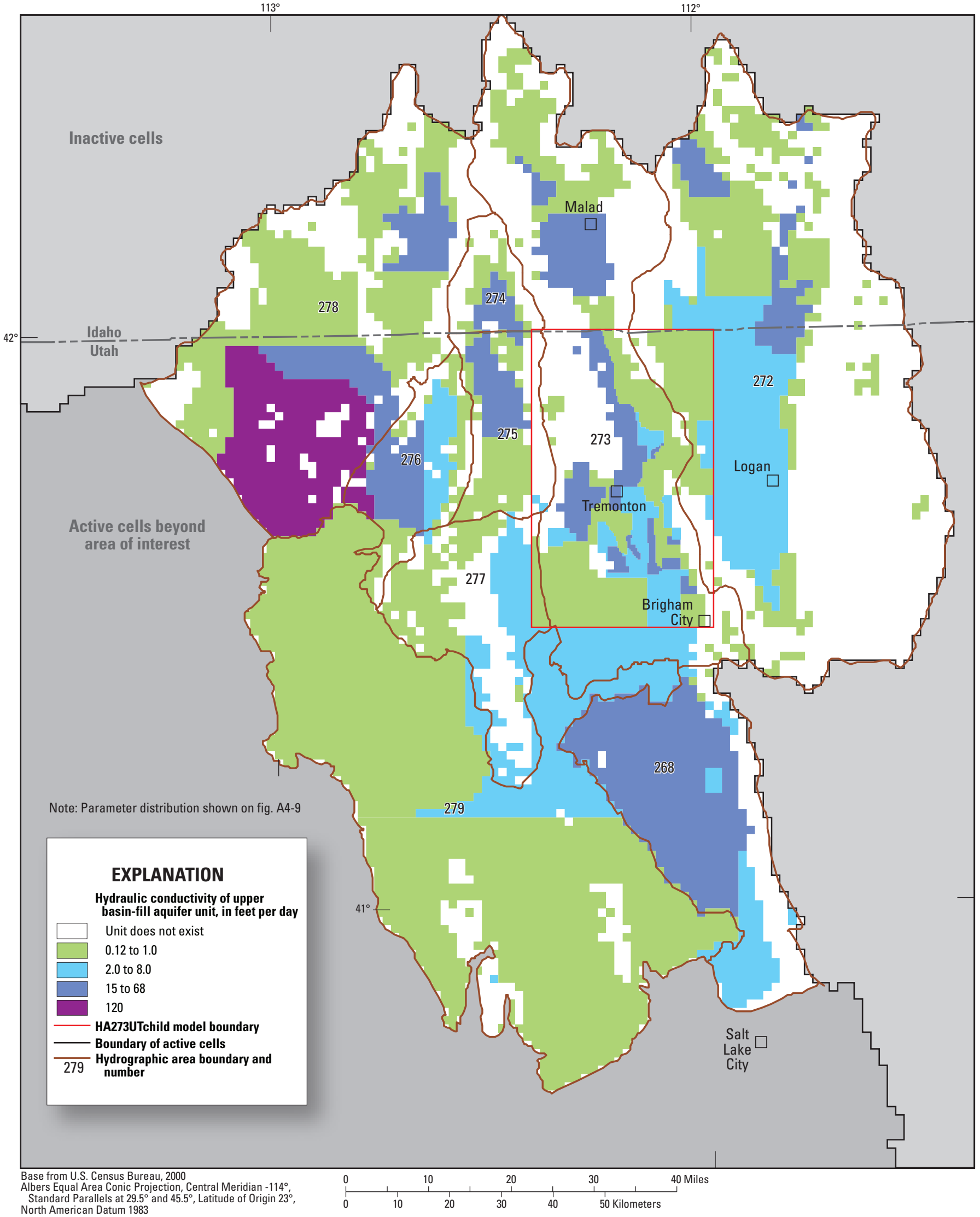

Figure A4-8. Distribution of hydraulic conductivity of the upper basin-fill aquifer unit (UBFAU) in the GBCAAS v. 2.0 groundwater model, Malad-Lower Bear River study area and surrounding areas, Utah and Idaho. 


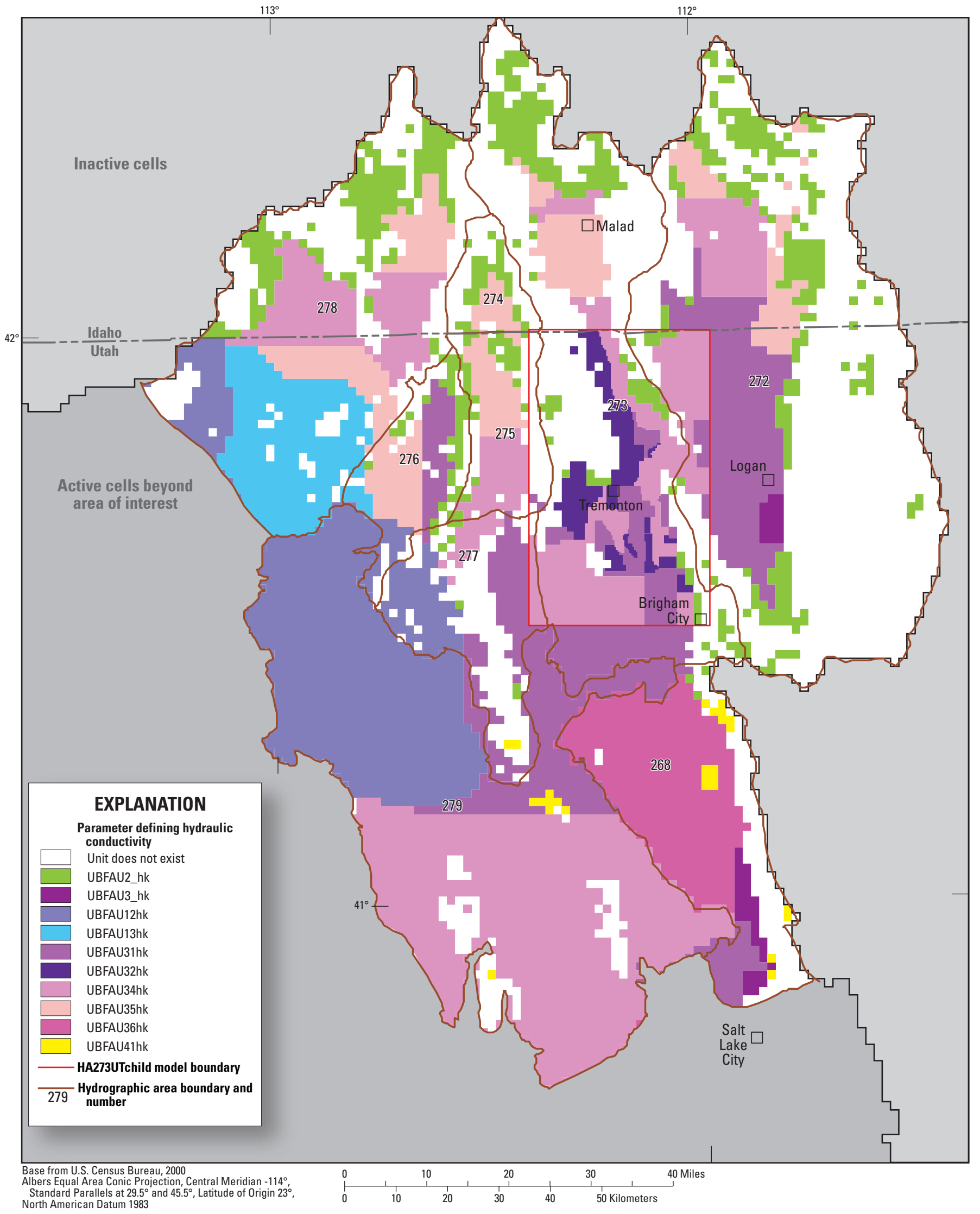

Figure A4-9. Distribution of model parameters defining hydraulic conductivity of the upper basin-fill aquifer unit (UBFAU) in the GBCAAS v. 2.0 groundwater model, Malad-Lower Bear River study area and surrounding areas, Utah and Idaho. 
Table A4-5. Parameter values and statistics for horizontal-to-vertical anisotropy of all hydrogeologic units in the GBCAAS v. 2.0 groundwater model, Great Basin carbonate and alluvial aquifer system study area.

[Model zone: zone number used in MODFLOW files. 95-percent confidence interval: 95-percent linear confidence interval as calculated by UCODE_2005 (Poeter and others, 2008, p. 174). Standard deviation of log values: calculated by UCODE_2005 (Poeter and others, 2008). Abbreviations: NCCU, noncarbonate confining unit; TNCCU, thrusted non-carbonate confiining unit; LCAU, lower carbonate aquifer unit; TLCAU, thrusted lower carbonate aquifer unit; USCU, upper siliciclastic confining unit; UCAU, upper carbonate aquifer unit; VU, volcanic unit; LBFAU, lower basin-fill aquifer unit; UBFAU, upper basin-fill aquifer unit]

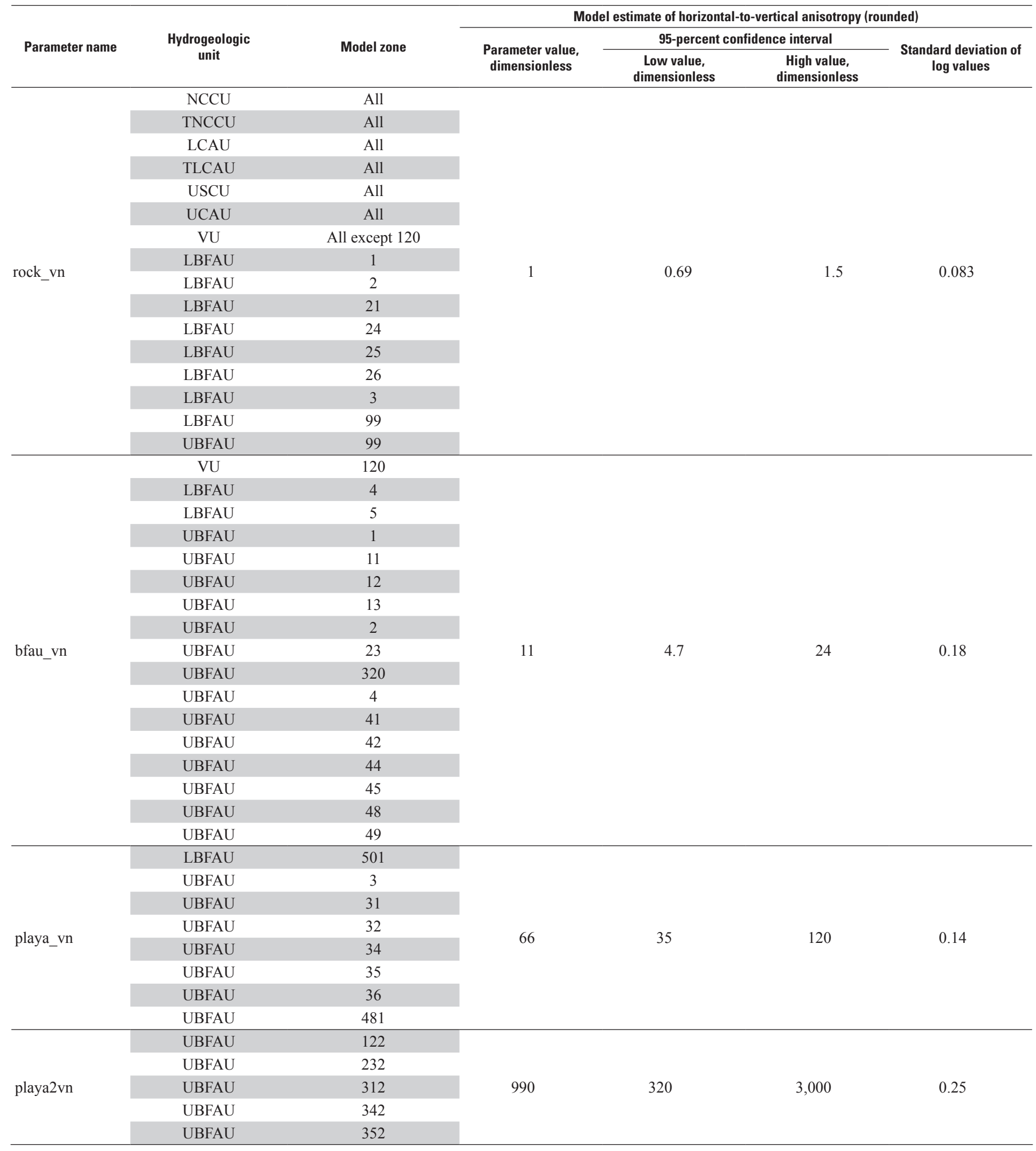




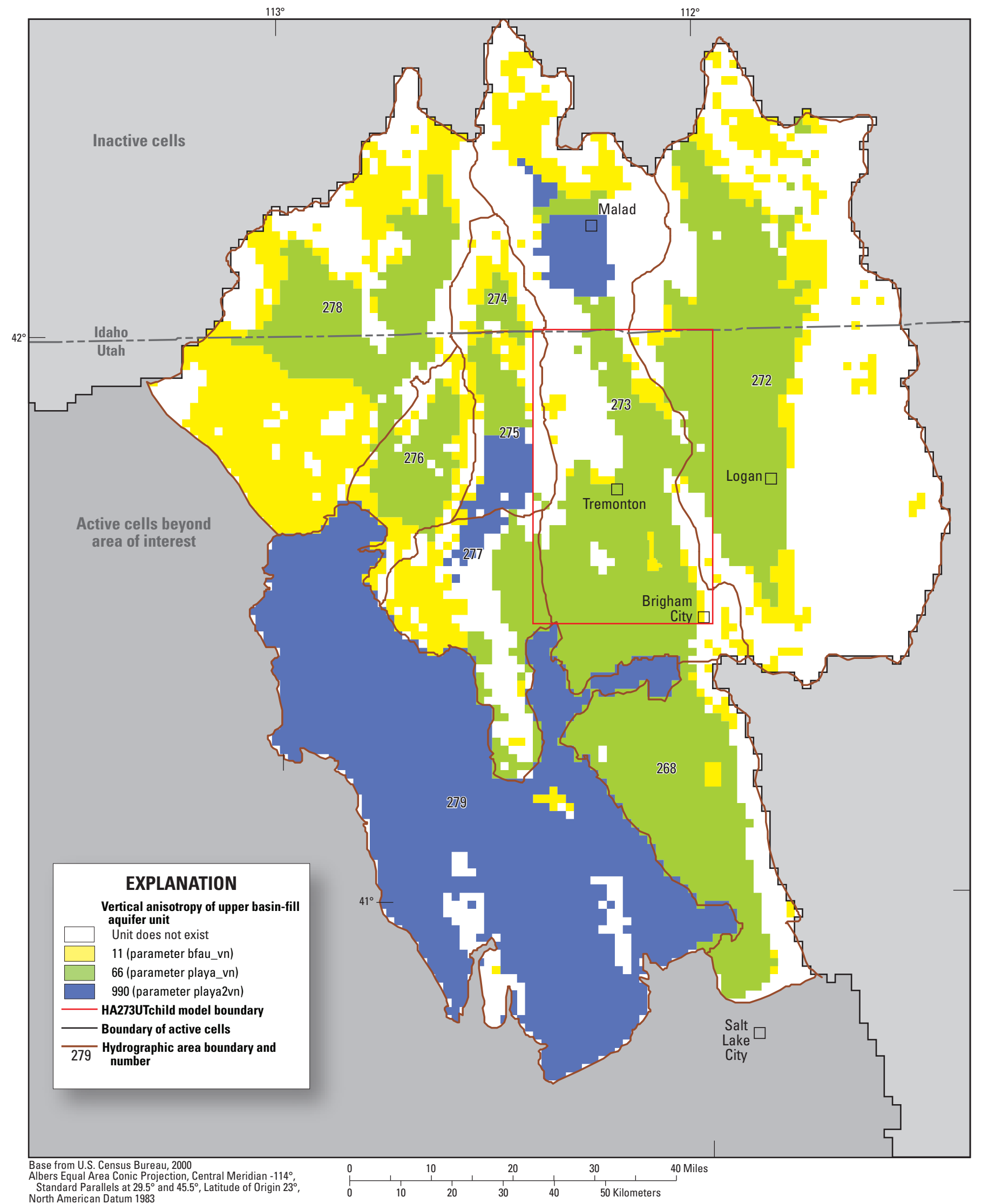

Figure A4-10. Distribution of vertical anisotropy of the upper basin-fill aquifer unit (UBFAU) in the GBCAAS v. 2.0 groundwater model, Malad-Lower Bear River study area and surrounding areas, Utah and Idaho. 
Table A4-6. Simulated values at discharge observations for different values of vertical anisotropy of the upper basin-fill aquifer unit in the HA273UTchild model, Malad-Lower Bear River study area.

[All values in cubic feet per day]

\begin{tabular}{|c|c|c|c|c|}
\hline Observation & Observed value & $\begin{array}{l}\text { playa_vn }=10.7 \\
\text { Simulated value }\end{array}$ & $\begin{array}{c}\text { Calibrated playa_vn }=66.05 \\
\text { Simulated value }\end{array}$ & $\begin{array}{c}\text { playa_vn }=987 \\
\text { Simulated value }\end{array}$ \\
\hline ET273Other & $-191,000$ & $-417,906$ & $-392,022$ & $-358,758$ \\
\hline ET273Plymout & $-286,000$ & $-475,860$ & $-449,719$ & $-412,122$ \\
\hline ET273Perry & $-274,300$ & $-296,283$ & $-225,694$ & $-174,026$ \\
\hline gha272_30 & $-173,259$ & $-177,361$ & $-185,398$ & $-192,379$ \\
\hline S273_5 & $-86,629$ & $-95,939$ & $-99,651$ & $-105,873$ \\
\hline S273_7 & $-27,914$ & $-24,283$ & $-29,902$ & $-39,412$ \\
\hline S273_10 & $-126,039$ & $-75,174$ & $-130,075$ & $-174,596$ \\
\hline S273_15 & $-89,904$ & $-76,627$ & $-89,139$ & $-98,807$ \\
\hline S273_16 & $-113,960$ & $-65,920$ & $-98,021$ & $-117,811$ \\
\hline S273_20 & $-161,434$ & $-70,565$ & $-136,391$ & $-187,769$ \\
\hline S273_22 & $-264,706$ & $-306,345$ & $-317,542$ & $-329,384$ \\
\hline S273_23 & $-103,014$ & $-68,891$ & $-112,744$ & $-134,644$ \\
\hline S273_24 & $-30,882$ & $-57,462$ & $-62,895$ & $-80,044$ \\
\hline S273SaltW & $-1,770,014$ & $-1,587,369$ & $-1,722,860$ & $-1,928,117$ \\
\hline S273Crystal & $-689,221$ & $-660,950$ & $-748,143$ & $-779,600$ \\
\hline S273Cold & $-241,835$ & $-224,193$ & $-225,114$ & $-217,698$ \\
\hline S273Dewey & $-130,209$ & $-110,874$ & $-151,241$ & $-172,380$ \\
\hline S273Garland & $-278,323$ & $-215,735$ & $-251,430$ & $-266,492$ \\
\hline S273Hadley & $-75,546$ & $-57,082$ & $-72,581$ & $-94,272$ \\
\hline S273Honey8 & $-157,189$ & $-160,293$ & $-164,650$ & $-169,302$ \\
\hline S273Udy & $-466,416$ & $-500,823$ & $-468,409$ & $-441,127$ \\
\hline SB1124bbc & $-28,512$ & $-8,706$ & $-37,196$ & $-69,481$ \\
\hline SB1225cca & $-86,631$ & $-106,676$ & $-79,626$ & $-77,071$ \\
\hline DB1226bac & $-134,579$ & $-7,456$ & $-132,159$ & $-508,116$ \\
\hline SB12230cdd & $-86,631$ & $-28,562$ & $-95,594$ & $-162,598$ \\
\hline SB14327dcb & $-12,824$ & $-1,610$ & $-8,206$ & $-15,541$ \\
\hline SB9212baa & $-19,251$ & 0 & $-14,700$ & $-39,597$ \\
\hline SB9212daa & $-259,893$ & $-205,024$ & $-259,572$ & $-296,646$ \\
\hline D273Corinne & $-83,000$ & $-146,225$ & $-224,205$ & $-306,853$ \\
\hline D273SaltCrE & $-270,000$ & $-442,353$ & $-299,925$ & $-256,055$ \\
\hline D273SaltW1 & $-223,776$ & $-169,648$ & $-190,389$ & $-193,825$ \\
\hline D273SaltW2 & $-140,000$ & $-116,678$ & $-152,299$ & $-188,481$ \\
\hline D273Sulphur1 & $-52,704$ & $-33,810$ & $-52,207$ & $-69,789$ \\
\hline D273Sulphur2 & $-880,000$ & $-241,785$ & $-304,990$ & $-340,029$ \\
\hline S273BkSlough & $-1,600,000$ & $-1,929,824$ & $-1,420,525$ & $-880,154$ \\
\hline S273Jesse & $-773,770$ & $-464,829$ & $-653,266$ & $-812,745$ \\
\hline S273Sulphur3 & $-450,000$ & $-455,818$ & $-428,465$ & $-344,564$ \\
\hline S273WLitMt & $-1,800,000$ & $-2,046,613$ & $-1,681,691$ & $-1,327,657$ \\
\hline R273Malad1 & $-560,000$ & $-832,221$ & $-819,195$ & $-706,226$ \\
\hline R273Malad2 & $-260,000$ & $-216,708$ & $-232,906$ & $-255,803$ \\
\hline R273Bear1 & $-1,500,000$ & $-1,657,257$ & $-1,386,084$ & $-836,164$ \\
\hline RMalad3 & $-200,000$ & $-116,428$ & $-171,996$ & $-238,305$ \\
\hline RMalad4 & $-200,000$ & $-32,462$ & $-167,063$ & $-303,684$ \\
\hline RMalad5 & $-360,000$ & $-196,179$ & $-270,352$ & $-338,458$ \\
\hline RMalad6 & $-520,000$ & $-381,821$ & $-445,889$ & $-471,464$ \\
\hline RMalad7 & $-90,000$ & 70,241 & $-103,177$ & $-261,933$ \\
\hline RMalad8 & $-480,000$ & $-249,737$ & $-413,132$ & $-852,864$ \\
\hline RBear2 & $-2,400,000$ & $-2,878,192$ & $-2,035,657$ & $-1,380,956$ \\
\hline RBear3 & $-4,900,000$ & $-4,006,177$ & $-4,205,674$ & $-4,151,534$ \\
\hline $\begin{array}{l}\text { Standard error of } \\
\text { regression for these } \\
\text { observations }\end{array}$ & & 210,301 & 157,264 & 270,866 \\
\hline
\end{tabular}


Table A4-7. Parameter values and statistics for evapotranspiration conductance multiplier, drain leakance, river conductivity, and river leakance in the GBCAAS v. 2.0 groundwater model, Great Basin carbonate and alluvial aquifer system study area.

[Parameter name: Evapotranspiration (et), dimensionless multiplier of the conductance; discharge, per day for drains, feet per day for rivers; river, feet per day; river273, per day. 95-percent confidence interval: 95-percent linear confidence interval as calculated by UCODE_2005 (Poeter and others, 2008, p. 174). Standard deviation of log values: calculated by UCODE_2005 (Poeter and others, 2008)]

\begin{tabular}{|c|c|c|c|c|c|}
\hline \multirow{3}{*}{ Parameter name } & \multirow{3}{*}{$\begin{array}{l}\text { Location by } \\
\text { hydrographic area number }\end{array}$} & \multicolumn{4}{|c|}{ Model estimate of parameter } \\
\hline & & \multirow{2}{*}{ Parameter value } & \multicolumn{2}{|c|}{ 95-percent confidence interval } & \multirow{2}{*}{$\begin{array}{l}\text { Standard deviation of log } \\
\text { values }\end{array}$} \\
\hline & & & Low value & High value & \\
\hline et_beryl & 280 to 284 & 1.4 & 1. & 1.9 & 0.069 \\
\hline et_deathval & $\begin{array}{l}146,162,163,170,212,228 \\
230,240,241,242,243\end{array}$ & 2. & 1. & 3.9 & 0.15 \\
\hline et_goshute & 179,187 & 1.9 & 1. & 3.7 & 0.14 \\
\hline et_gsldwest & $\begin{array}{l}184,185,253,254,257,258 \\
259,261 \mathrm{~A}\end{array}$ & 1.1 & 0.93 & 1.3 & 0.038 \\
\hline et_gslnorth & $\begin{array}{l}251,260 \mathrm{~A}, 260 \mathrm{~B}, 261 \mathrm{~B}, 273 \\
276,277,278\end{array}$ & 2.5 & 1.4 & 4.6 & 0.13 \\
\hline et_gslsouth & $262,263,267,269,270$ & 2. & 1.1 & 3.7 & 0.13 \\
\hline et_reese & $55,56,137 \mathrm{~B}, 138$ & 0.98 & 0.61 & 1.6 & 0.11 \\
\hline et_sevier & 285 to 287 & 2.2 & 1.3 & 3.7 & 0.11 \\
\hline et265 & 265,266 & 1.5 & 0.93 & 2.4 & 0.11 \\
\hline et268 & 268 & 0.99 & 0.6 & 1.6 & 0.11 \\
\hline et 272 & $272,273,275$ & 1.3 & 0.82 & 2.1 & 0.1 \\
\hline discharge & multiple & 0.5 & 0.23 & 1.1 & 0.17 \\
\hline river & multiple & 50. & 0.4 & 6,200 & 1.1 \\
\hline river273 & 273 & 0.15 & 0.0093 & 2.5 & 0.62 \\
\hline
\end{tabular}

Table A4-8. Parameter values and statistics for the hydraulic characteristic of horizontal-flow barriers in the GBCAAS v. 2.0 groundwater model, Great Basin carbonate and alluvial aquifer system study area.

[95-percent confidence interval: 95-percent linear confidence interval as calculated by UCODE_2005 (Poeter and others, 2008, p. 174). Standard deviation of log values: calculated by UCODE_2005 (Poeter and others, 2008)]

\begin{tabular}{|c|c|c|c|c|}
\hline \multirow{3}{*}{ Parameter name } & \multicolumn{4}{|c|}{ Model estimate of parameter } \\
\hline & \multirow{2}{*}{$\begin{array}{l}\text { Parameter value, } \\
\text { in feet per day }\end{array}$} & \multicolumn{2}{|c|}{ 95-percent confidence interval } & \multirow{2}{*}{$\begin{array}{c}\text { Standard deviation of log } \\
\text { values }\end{array}$} \\
\hline & & $\begin{array}{l}\text { Low value, } \\
\text { in feet per day }\end{array}$ & $\begin{array}{l}\text { High value, } \\
\text { in feet per day }\end{array}$ & \\
\hline b_hfb1 & $1.00 \mathrm{E}-08$ & $1.40 \mathrm{E}-10$ & $7.00 \mathrm{E}-07$ & 0.94 \\
\hline b_deepck & $1.40 \mathrm{E}-07$ & $6.30 \mathrm{E}-08$ & $3.10 \mathrm{E}-07$ & 0.18 \\
\hline b_dv_n2 & $1.80 \mathrm{E}-07$ & $7.90 \mathrm{E}-08$ & $4.00 \mathrm{E}-07$ & 0.18 \\
\hline b_steptoe & $2.70 \mathrm{E}-07$ & $1.00 \mathrm{E}-07$ & $6.90 \mathrm{E}-07$ & 0.21 \\
\hline b_hfb2 & $5.00 \mathrm{E}-07$ & $2.60 \mathrm{E}-08$ & $9.50 \mathrm{E}-06$ & 0.65 \\
\hline b_lvvsz & $1.10 \mathrm{E}-06$ & $8.30 \mathrm{E}-08$ & $1.40 \mathrm{E}-05$ & 0.57 \\
\hline b_spring & $1.00 \mathrm{E}-05$ & $7.20 \mathrm{E}-09$ & $1.40 \mathrm{E}-02$ & 1.60 \\
\hline
\end{tabular}




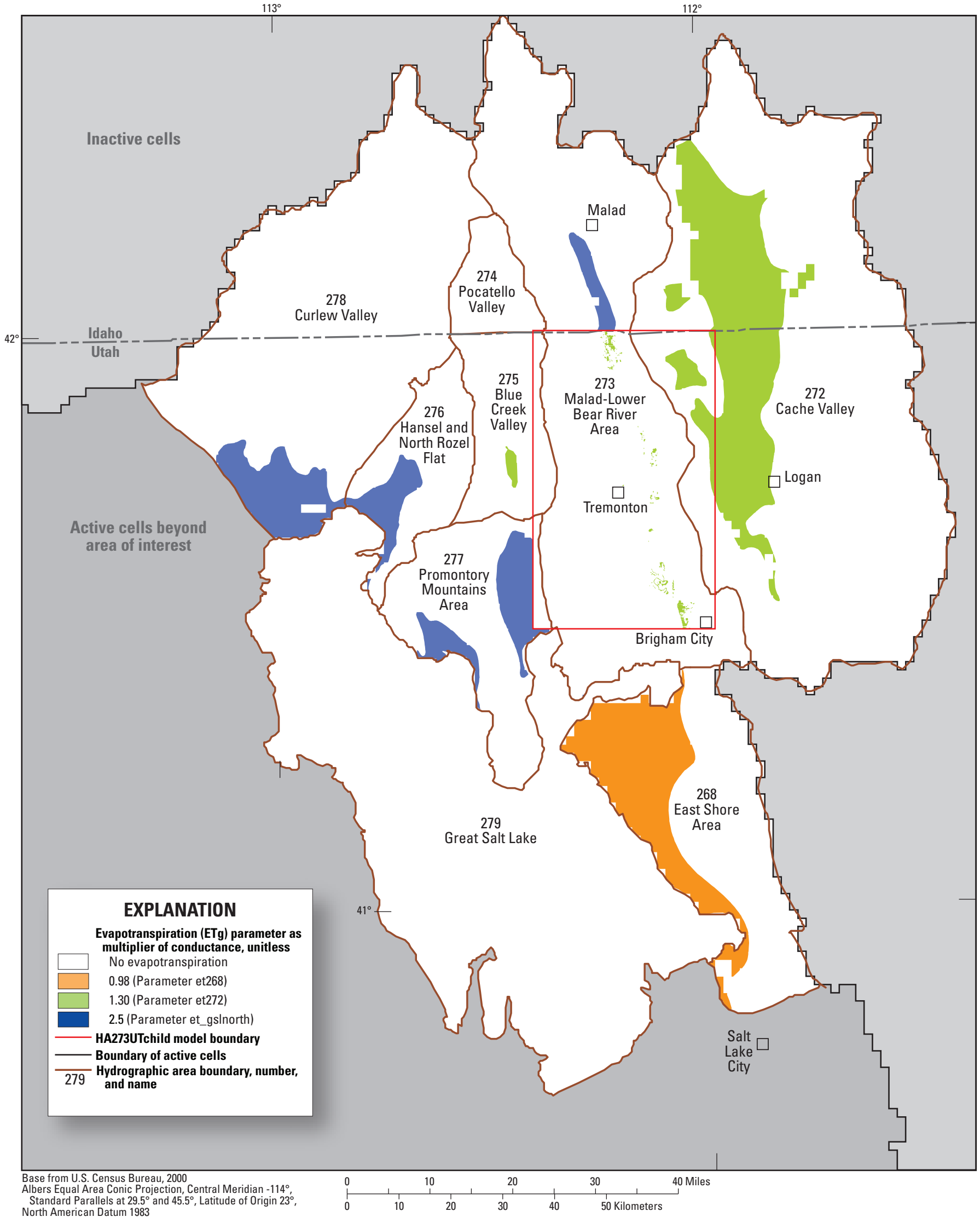

Figure A4-11. Distribution of parameter values for evapotranspiration of groundwater (ETg) in the GBCAAS v. 2.0 groundwater model, Malad-Lower Bear River study area and surrounding areas, Utah and Idaho. 


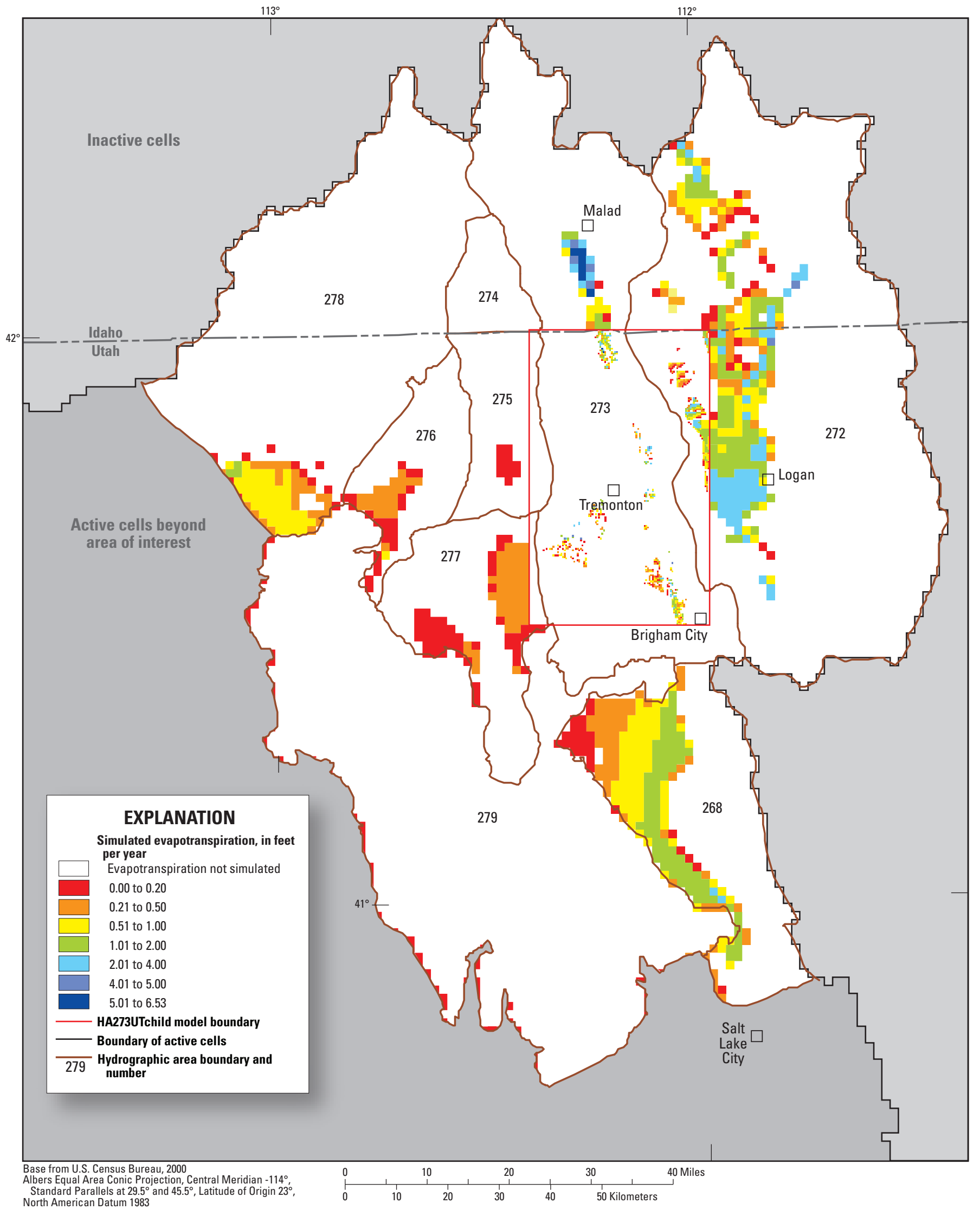

Figure A4-12. Distribution of simulated evapotranspiration in the GBCAAS v. 2.0 groundwater model, Malad-Lower Bear River study area and surrounding areas, Utah and Idaho. 


\section{Appendix 5. Changes to the Numerical Groundwater Flow Model Outside of the Child Model}

This appendix describes changes that were made in the GBCAASv2parent model to enable the calibration and model results of GBCAAS v. 2.0 to be similar to GBCAAS v. 1.0 outside of the Malad-Lower Bear River study area. These changes were necessary mostly because the reduced recharge within the study area has effects outside of the study area.

\section{Changes to Recharge}

The rate of in-place recharge was not changed in the parent model from the GBCAAS v. 1.0 model except in zone rch275 west of the study area (fig. A4-1), where the value of the parameter was increased from 6.47 to 6.64 to partly account for less recharge within the study area. Recharge from runoff was also changed in 39 cells in the GBCCASv2parent model in Malad-Lower Bear River Area (HA 272) and Cache Valley (HA 273) to match the new concept of where recharge occurs (fig. 24C). Recharge from baseflow (fig. 24D) was reduced from $0.091 \mathrm{ft} / \mathrm{yr}$ to 0 in 15 cells to be consistent with the lack of baseflow in the study area. Recharge with imported water (fig. 24E) was reduced in the GBCAASv2parent model in the area south of Brigham City to be consistent with water diverted from Box Elder Creek and the Ogden-Brigham Canal (fig. 1, table 4). The recharge zone of 23 GBCAASv2parent model cells near the HA273UTchild model was changed to be consistent with zones 2721 and 2722; two cells were changed from no recharge zone to zones 272 or 273 to match the more detailed location of recharge (fig. A4-1). Simulated recharge (fig. 24F), therefore, is different in these few areas than in the GBCAAS v. 1.0 model.

\section{Changes to Discharge}

Evapotranspiration of groundwater (ETg) was eliminated in the GBCAASv2parent model from the area south of the HA273UTchild model in the study area (figs. A4-11 and A4-12). This study concluded that surface water, not groundwater, is supplying the water demand of vegetation in that area (see "Groundwater Budget" section of this report).

\section{Changes to Hydraulic Conductivity}

The horizontal hydraulic conductivity of small areas of the LCAU (figs. A4-5 and A4-6) was changed outside the child model in the parent model to be consistent with the child model. The horizontal hydraulic conductivity (figs. A4-8 and A4-9) and anisotropy (fig. A4-10) of the UBFAU were decreased in Blue Creek Valley (HA 275) to improve model fit in GBCAAS v. 2.0, which deteriorated because of reduced recharge within the HA273UTchild model. 


\section{Appendix 6. Model Results}

This appendix documents water-level changes, model fit to observations, and model budgets for the GBCAAS v. 2.0 model for comparison with the GBCAAS v. 1.0 model (Brooks and others, 2014). The composite scaled sensitivities, parameter confidence intervals, and weighted residuals are similar to those in GBCAAS v. 1.0 and are not presented in this report. The data are available in the model archive.

Changes within and near the HA273UTchild model caused changes in simulated water levels in model layer 1 of greater than $1 \mathrm{ft}$ over an area extending about $40 \mathrm{mi}$ from the study area (fig. A6-1). The reduction in recharge within the study area resulted in lower simulated water levels mostly to the west of the study area. The reduction in ETg in the southern part of the study area resulted in higher simulated levels south of the study area, except where a change in hydraulic conductivity decreased water levels southeast of the HA273UTchild model. The reduction in horizontal hydraulic conductivity of the UBFAU within the child model resulted in higher simulated levels north of the study area. The average water-level residual in the area with a change in simulated water level of more than $1 \mathrm{ft}$ was a little high $(-0.13 \mathrm{ft})$ in GBCAAS v. 1.0 and is a little low $(0.43 \mathrm{ft}$; table A3-1) in GBCAAS v. 2.0.

As with water levels, substantial changes in simulated water budgets between GBCAAS v. 1.0 (Brooks and others, 2014) and GBCAAS v. 2.0 are limited to the Great Salt Lake simulated groundwater region and the boundary between the Great Salt Lake and Great Salt Lake Desert simulated groundwater regions (table A6-1; Brooks and others, 2014, table 12 and fig. 43). The groundwater budget for the Great Salt Lake simulated groundwater region was reduced from 2,100,000 to $2,000,000 \mathrm{acre}-\mathrm{ft} / \mathrm{yr}$, and simulated flow of $270 \mathrm{acre}-\mathrm{ft} / \mathrm{yr}$ from the Great Salt Lake Desert to the Great Salt Lake groundwater region occurs instead of $240 \mathrm{acre}-\mathrm{ft} / \mathrm{yr}$ in the other direction. Budget changes within HAs were also limited to HAs near the child model (table A6-2; Brooks and others, 2014, table A3-2).

Table A6-2. Comparison of conceptual and simulated recharge and discharge for each hydrographic area in the GBCAAS v. 2.0 groundwater model, Great Basin carbonate and alluvial aquifer system study area.

This table is distributed as part of this report in Microsoft Excel 2010 format and is available for download at https://doi.org/10.3133/sir20175011.
The distribution of residuals of water levels in wells (fig. A6-2A) and simulated discharge as percent of observed discharge (fig. A6-2B) in the GBCAASv2parent model in the Malad-Lower Bear River study area and surrounding areas indicate little change from the model fit in GBCAAS v. 1.0 in this area (Brooks and others, 2014, pl. 1 and 2). Changes to specific water-level observations outside of the Malad-Lower Bear River study area are less than $20 \mathrm{ft}$ in all but 13 wells (table A3-1), and no water-level observations in the parent model had residuals greater than $200 \mathrm{ft}$ or less than $-200 \mathrm{ft}$ that did not previously have residuals also outside this desired calibration range (Brooks and others, 2014, p. 64). The average weighted residual of 0.43 (table A3-1) in the area of change in simulated water levels, however, indicates that simulated water levels are below observed water levels in this area. Changes to discharge observations (table A3-6) indicate that outside of the Malad-Lower Bear River study area, no observations changed from being within 30 percent of the observation value to being outside of that calibration criterion (Brooks and others, 2014, p. 38).

The direction, amount, and confidence intervals of simulated flow between HAs (fig. A6-3, table A6-3) changed in the area surrounding the study area in comparison to those in GBCAAS v. 1.0 (Brooks and others, 2014, fig. A3-1 and table A3-3). Near the study area, simulated interbasin flow increased only from HA 272 (Cache Valley) to HA 273 (Malad-Lower Bear River Area). At other boundaries near the Malad-Lower Bear River study area, simulated interbasin flow is less, and the model predicts the flows with less confidence in the flow direction; this is probably because of less water in the system. At a few locations not near the study area, confidence intervals of the predictions changed because parameter statistics changed and arrows may be different (fig. A6-3) than in Brooks and others (2014, fig. A3-1), even though the predicted amount of flow did not change.

Table A6-3. Model-predicted flow between hydrographic areas in the GBCAAS v. 2.0 groundwater model, Great Basin carbonate and alluvial aquifer system study area.

This table is distributed as part of this report in Microsoft Excel 2010 format and is available for download at https://doi.org/10.3133/sir20175011. 


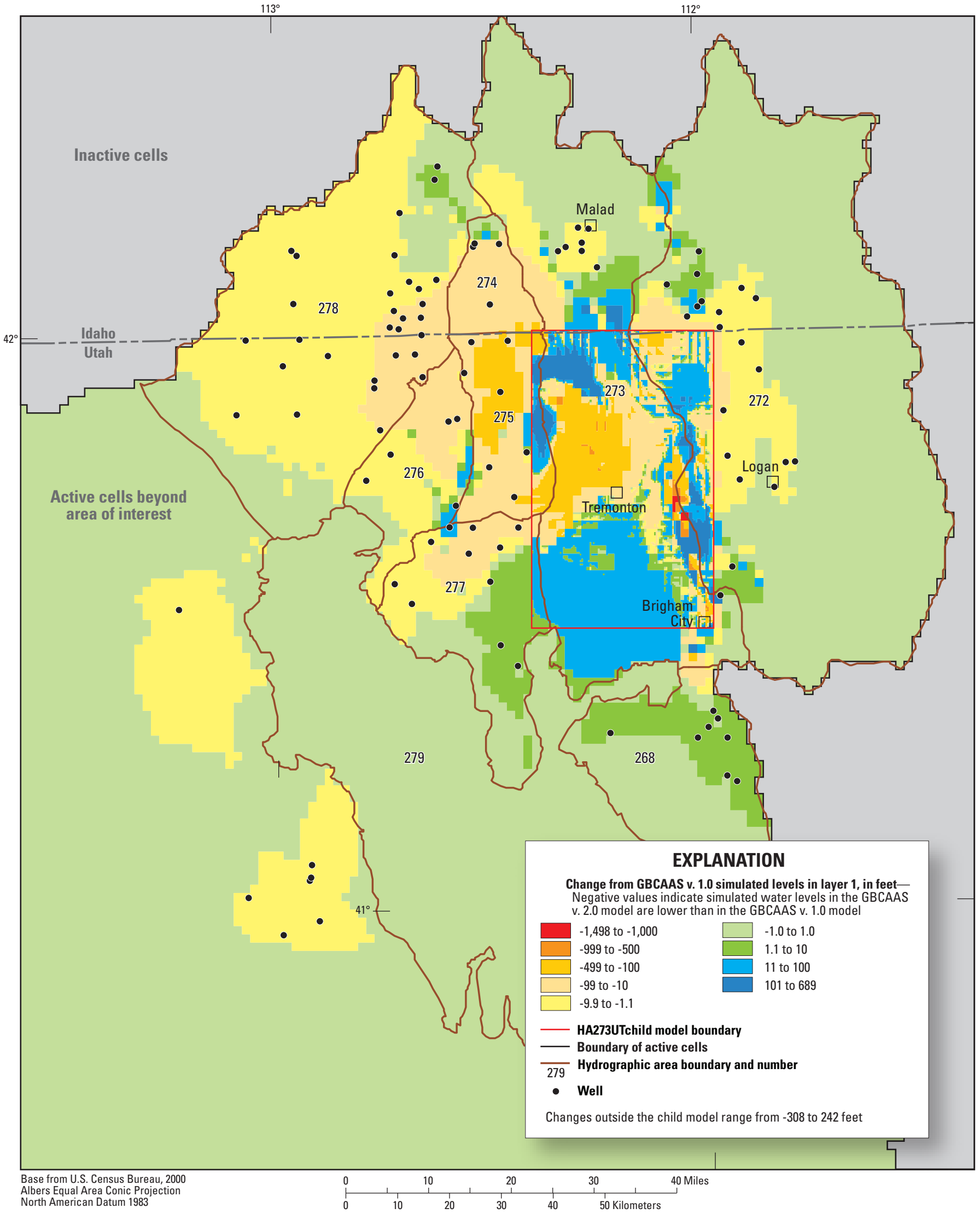

Figure A6-1. Change in simulated water levels in layer 1 from the GBCAAS v. 1.0 to the GBCAAS v. 2.0 groundwater models, MaladLower Bear River study area and surrounding areas, Utah and Idaho. 
Table A6-1. Groundwater budgets for the simulated groundwater regions and subregions in the GBCAAS v. 2.0 groundwater model, Great Basin carbonate and alluvial aquifer system study area.

[All flows in acre-feet per year rounded to two significant figures. —, not applicable]

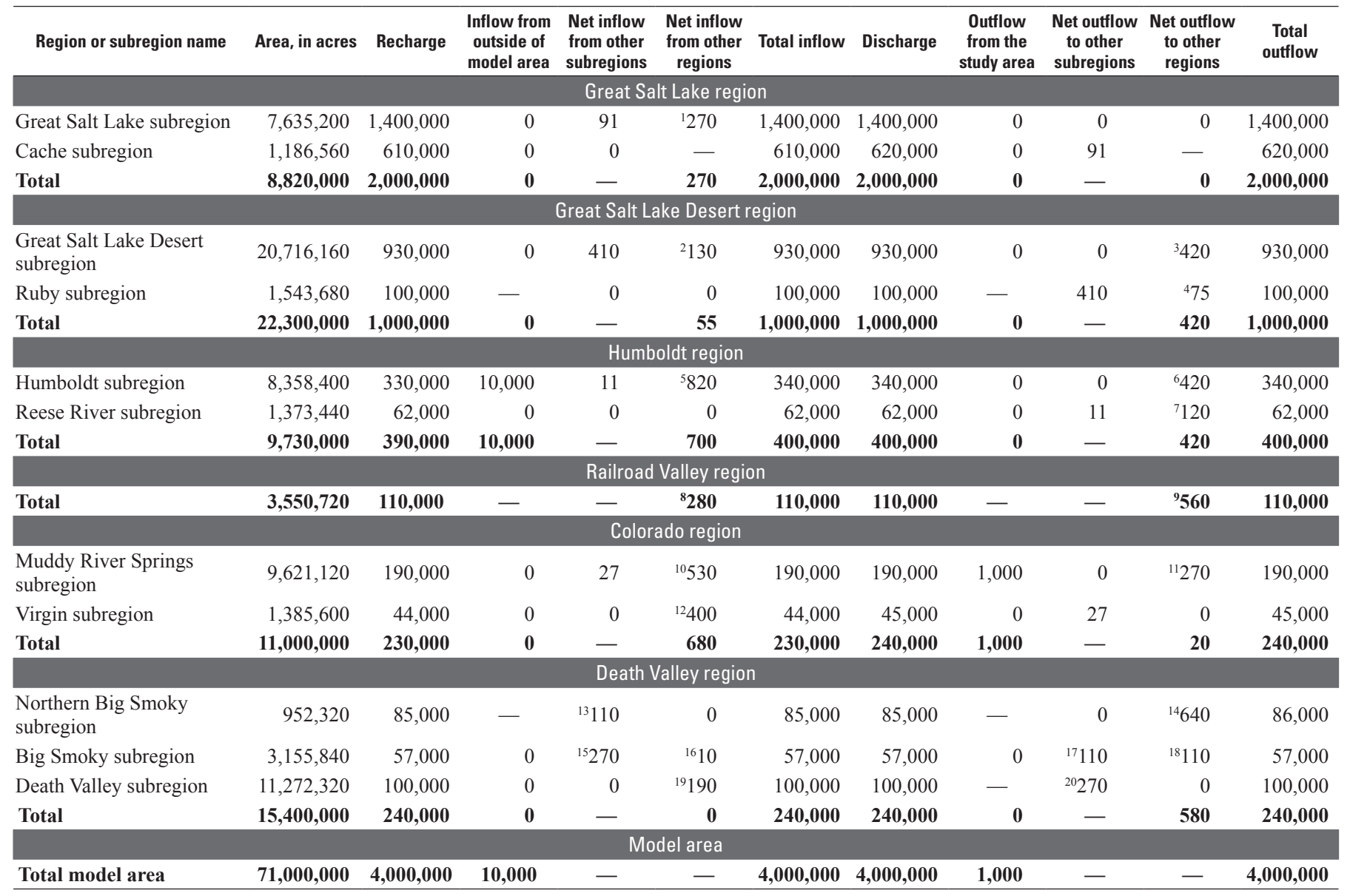

${ }^{1}$ From Great Salt Lake Desert region.

${ }^{2}$ From Humboldt region.

${ }^{3} 270$ acre-feet per year to Great Salt Lake region, 150 acre-feet per year to Colorado region.

${ }^{4}$ To Humboldt region.

${ }_{5}^{5} 420$ acre-feet per year from Death Valley region, 400 acre-feet per year from Railroad Valley region.

${ }^{6} 360$ acre-feet per year to Colorado region, 60 acre-feet per year to Great Salt Lake Desert region.

${ }^{7}$ To Death Valley region.

${ }^{8}$ From Death Valley region.

${ }^{9} 400$ acre-feet per year to Humboldt region, 170 acre-feet per year to Colorado region.

${ }^{10} 360$ acre-feet per year from Humboldt region, 170 acre-feet per year from Railroad Valley region.

${ }^{11} 250$ acre-feet per year to Great Salt Lake Desert region, 20 acre-feet per year to Death Valley region.

${ }^{12}$ From Great Salt Lake Desert region.

${ }^{13}$ From Big Smoky subregion.

${ }^{14} 310$ acre-feet per year to Humboldt region, 340 acre-feet per year to Railroad Valley region.

${ }^{15}$ From Death Valley subregion.

${ }^{16}$ From Humboldt region.

${ }^{17}$ To Northern Big Smoky subregion.

${ }^{18}$ To Railroad Valley region.

${ }^{19} 170$ acre-feet per year from Railroad Valley region, 20 acre-feet per year from Colorado region.

${ }^{20}$ To Big Smoky subregion. 


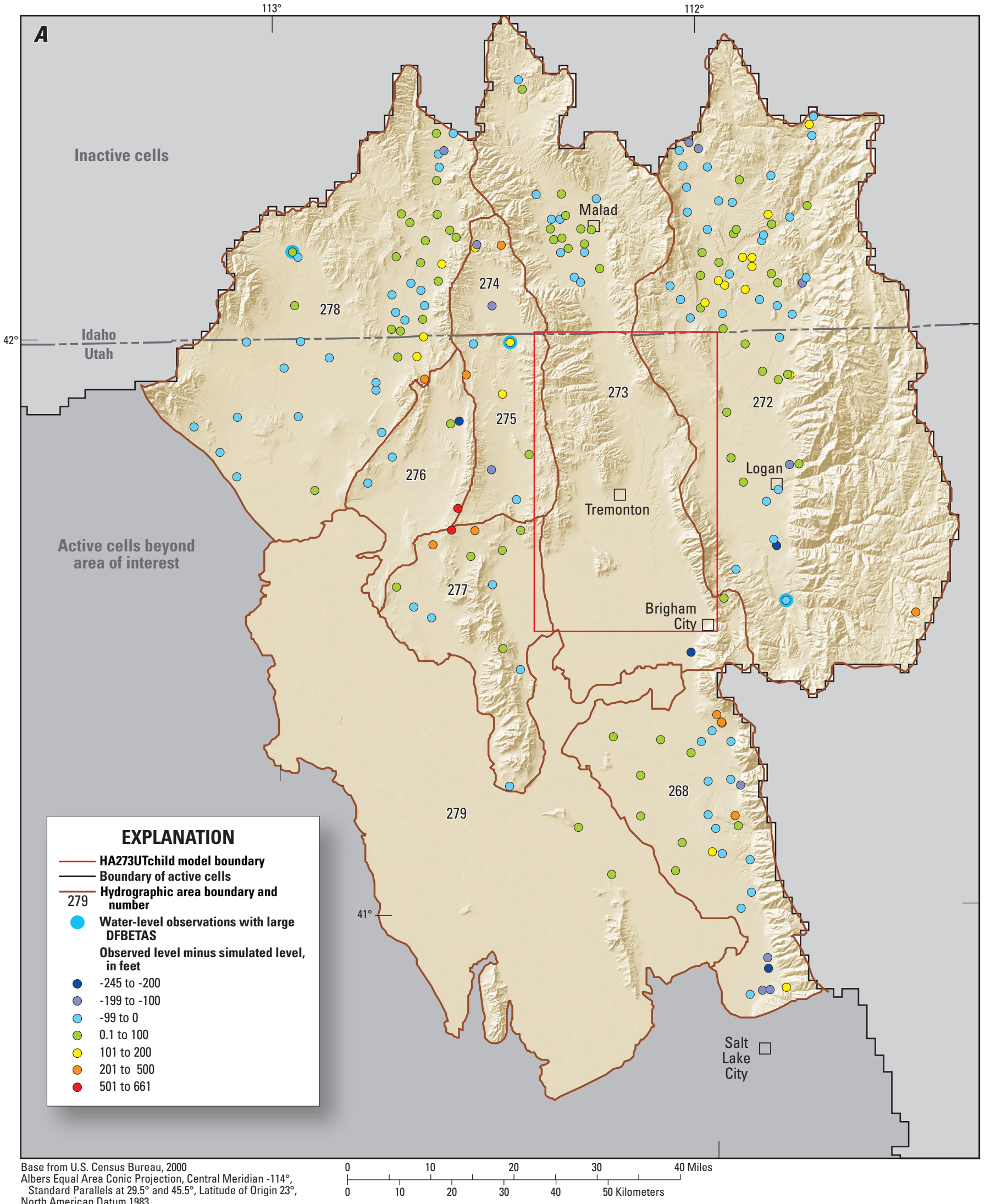

Figure A6-2. Location and model fit of observations used for calibration in the GBCAAS v. 2.0 groundwater model, Malad-Lower Bear River study area and surrounding areas, Utah and Idaho. $A$, simulated water-level residuals, and $B$, simulated discharge as percent of observed discharge. 


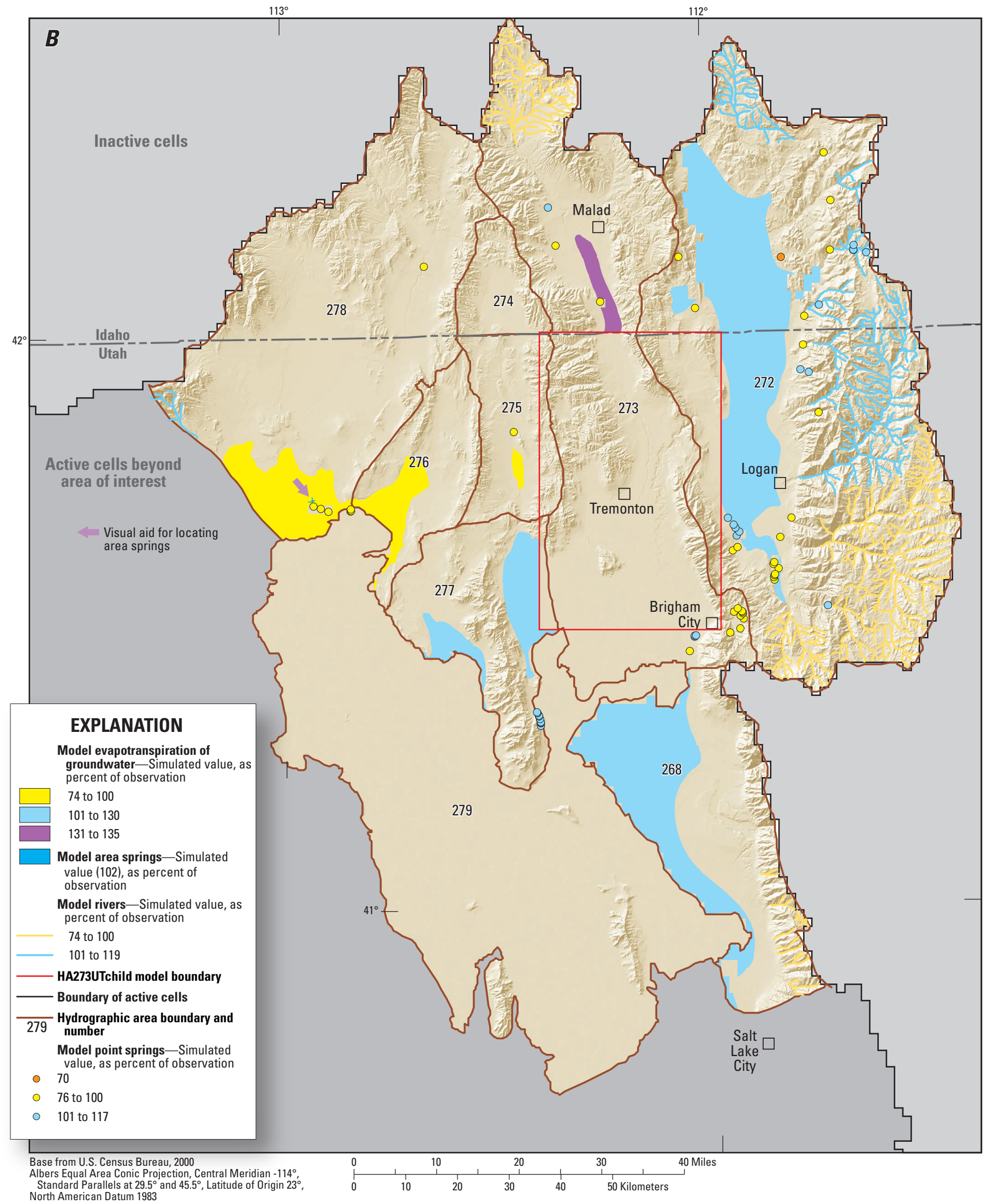

Figure A6-2. Location and model fit of observations used for calibration in the GBCAAS v. 2.0 groundwater model, Malad-Lower Bear River study area and surrounding areas, Utah and Idaho. $A$, simulated water-level residuals, and $B$, simulated discharge as percent of observed discharge.-Continued 


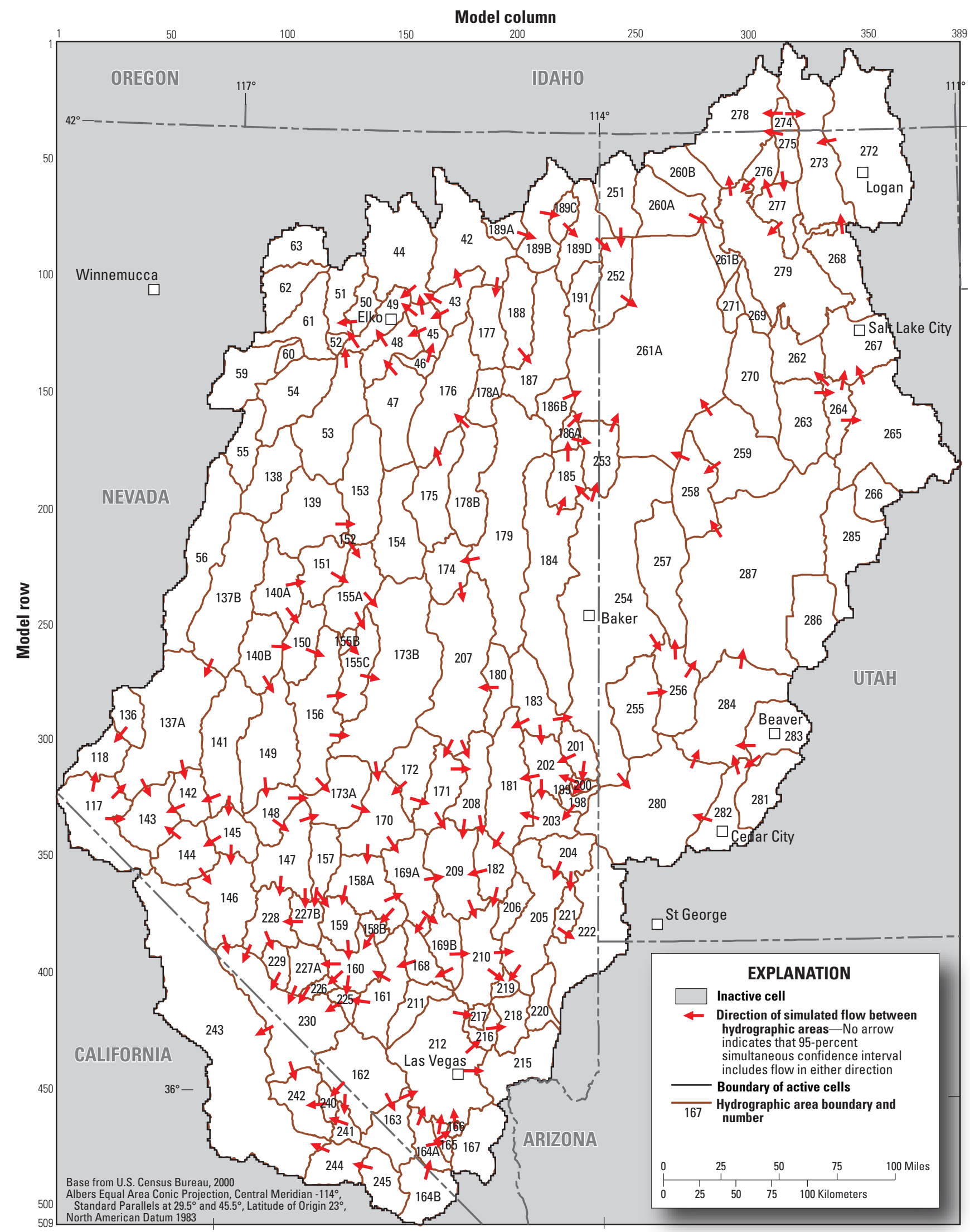

Figure A6-3. Direction of simulated subsurface flow between hydrographic areas in the GBCAAS v. 2.0 groundwater model, Great Basin carbonate and alluvial aquifer system study area. 
For additional information, contact:

Director, Utah Water Science Center U.S. Geological Survey

2329 West Orton Circle

Salt Lake City, UT 84119-2047

801 908-5000

http://ut.water.usgs.gov/ 



\section{$\frac{\mathbb{1}}{\mathrm{C}}$}

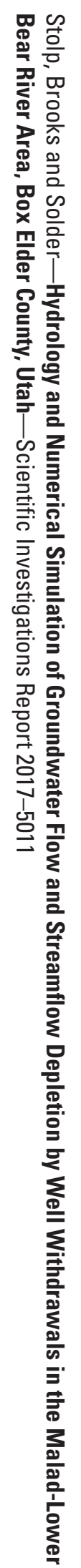

